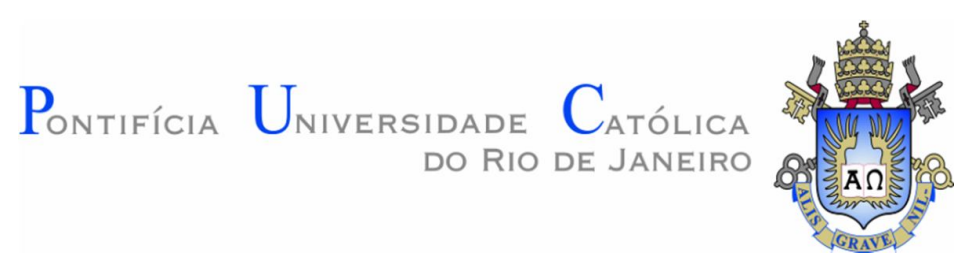

Ronny Machado de Moraes

\title{
Ensino-aprendizagem de conceitos científicos no ensino médio na concepção da Teoria Histórico-Cultural
}

\author{
Tese de doutorado
}

Tese apresentada como requisito parcial para obtenção do grau de Doutor pelo Programa de Pósgraduação em Educação do Departamento de Educação da PUC-Rio.

Orientadora: Prof. ${ }^{a}$ Zena Winona Eisenberg Coorientador: Prof. Fabiano Antônio dos Santos

Rio de Janeiro - RJ

Fevereiro de 2019 


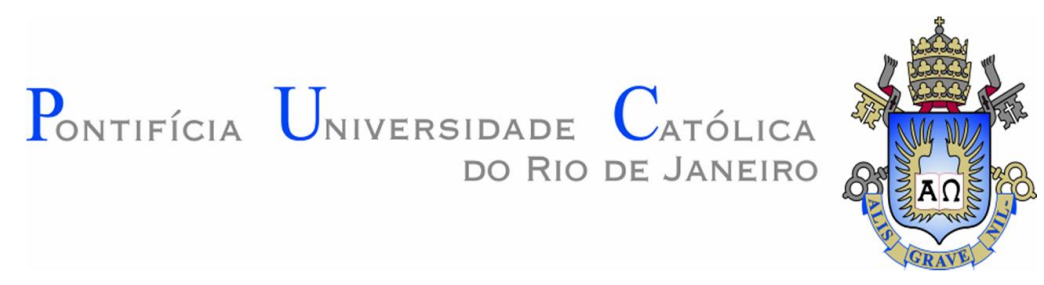

Ronny Machado de Moraes

\section{Ensino-aprendizagem de conceitos científicos no ensino médio na concepção da Teoria Histórico-Cultural}

Tese de doutorado

Tese apresentada como requisito parcial para obtenção do grau de Doutor pelo Programa de Pós-graduação em Educação da PUC-Rio. Aprovada pela Comissão Examinadora abaixo.

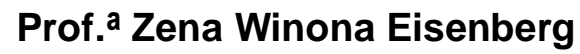

Orientadora

Departamento de Educação - PUC-Rio

Prof. Fabiano Antônio dos Santos

Coorientador

Universidade Federal de Mato Grosso do Sul - UFMS

Prof. Ralph Ings Bannell

Departamento de Educação - PUC-Rio

Prof. a Rosália Maria Duarte

Departamento de Educação - PUC-Rio

Prof.. Silvana Calvo Tuleski

Universidade Estadual de Maringá - UEM

Prof. . Vera Maria Ramos de Vasconcellos Universidade Estadual do Rio de Janeiro - UERJ

Rio de janeiro, 26 de Fevereiro 2019 
Todos os direitos reservados. É proibida a reprodução total ou parcial do trabalho sem autorização da universidade, do autor e do orientador.

\section{Ronny Machado de Moraes}

Licenciado em Ciências Biológicas pela Universidade Católica Dom Bosco - UCDB. Cursou mestrado em Educação pela mesma universidade, especializando-se em processos educativos. De 2015 a 2018, cursou o doutorado em Educação em Ciências Humanas pela PUC-RJ. Trabalha como docente do ensino superior desde 2006, ministrando disciplinas nas áreas de neuropsicologia e psicologia do desenvolvimento humano.

Ficha catalográfica

Moraes, Ronny Machado de

Ensino-aprendizagem de conceitos científicos no ensino médio na concepção da teoria histórico-cultural / Ronny Machado de Moraes ; orientadora: Zena Winona Eisenberg ; co-orientador: Fabiano Antônio dos Santos. 2019.

205 f. : il. ; $30 \mathrm{~cm}$

Tese (doutorado)-Pontifícia Universidade Católica do Rio de Janeiro, Departamento de Educação, 2019.

Inclui bibliografia

1. Educação - Teses. 2. Teoria da atividade. 3. Formação de conceitos. 4. Adolescência. 5. Ensino médio. 6. Teoria histórico-cultural. I. Eisenberg, Zena Winona. II. Santos, Fabiano Antônio dos. III. Pontifícia Universidade Católica do Rio de Janeiro. Departamento de Educação. IV. Título.

CDD: 370 


\section{Agradecimentos}

À Professora Zena Eisenberg, pela confiança em meu trabalho e pelo cuidado dispensado no direcionamento da pesquisa, ao mesmo tempo em que me proporcionou a autonomia necessária para a tomada de decisões.

Ao meu coorientador, Professor Fabiano Antônio dos Santos, pelas preciosas contribuições ao longo do processo. Seu auxílio foi fundamental, especialmente em relação aos fundamentos teórico-epistemológicos.

Às companheiras do Grupo de Estudos Desenvolvimento Humano e Educação GRUDHE da PUC/RJ que, de forma direta ou indireta, participaram com importantes reflexões na construção do meu objeto de estudo, sobretudo na discussão dos roteiros das entrevistas.

Aos meus pais que, mesmo podendo ser considerados semiletrados, não deixaram de reconhecer e estimular a continuidade dos meus estudos.

À minha companheira Kenia Uehara, pela compreensão nas minhas diversas formas de ausências. Também a agradeço pelas várias e cansativas leituras e correções deste texto.

Ao meu filho Yan Uehara, também pela leitura do texto e a tradução do resumo para a língua inglesa.

Ao meu filho Kevyan Uehara, pela verificação da conformidade das referências bibliográficas.

Aos companheiros da célebre "República do Pantanal": Ana Karla, Gilson e Rogers, com os quais compartilhei a vida no RJ no período de estágio do doutorado.

Às professoras Alícia, Isabel (Bel) e Rosália, da PUC-RJ, pelas relevantes ponderações em suas respectivas áreas de conhecimento. 
Ao professor Marcelo Sorrentino, da PUC-RJ, pelas discussões sobre o papel da cultura na gênese da subjetividade humana.

Ao professor Ralph, da PUC-RJ, pelos significativos aportes sobre o meu objeto de estudo, especialmente em relação à ideia do sujeito situado, com o corpo 'acoplado' ao ambiente físico-cultural.

Aos componentes da banca do exame de qualificação I, professoras Zoia Prestes e Rosália Duarte, pelos valiosos comentários sobre o projeto de pesquisa.

Aos componentes da banca do exame de qualificação II, professor Fabiano dos Santos e professoras Mônica Kassar e Inara Leão, pela disponibilidade em colaborar com análises sobre os resultados da tese.

À Fundação de Apoio ao Desenvolvimento do Ensino, Ciência e Tecnologia do Estado de Mato Grosso do Sul- FUNDECT, pelo aporte de recursos ao projeto do DINTER, na certeza de que as condições materiais são decisivas na conclusão da empreitada de pesquisa.

Às professoras e professores do Programa de Pós-Graduação em Educação PPGE/UFMS, Campus do Pantanal, na certeza de que seus esforços subsidiaram a viabilização do Dinter.

À Professora Mônica Kassar, um agradecimento especial, porque, mesmo em tempos de conjuntura desfavorável, não mediu esforços para a viabilização do doutorado em educação, na modalidade Dinter, no Campus do Pantanal.

Às professoras participantes da pesquisa, que gentilmente me permitiram adentrar na intimidade das suas salas de aulas para realizar as observações necessárias a este estudo.

A todos os estudantes envolvidos nesta pesquisa, um agradecimento especial, na esperança de que este trabalho possa, de alguma maneira, cooperaram para a melhoria do processo de ensino-aprendizagem, especificamente em relação à formação dos conceitos científicos. 


\section{Resumo}

Moraes, Ronny Machado; Eisenberg, Zena Winona. Ensinoaprendizagem de conceitos científicos no ensino médio na concepção da Teoria Histórico-Cultural. Rio de janeiro, 2019. 205p. Tese de doutorado - Departamento de Educação, Pontifícia Universidade Católica do Rio de Janeiro.

Este estudo teve como foco investigar como se dá o processo de formação de conceitos científicos, especificamente no ambiente de uma sala de aula, utilizando como metodologia a Teoria Geral da Atividade do psicopedagogo russo Alexei Nikolaivich Leontiev (1903-1979), apoiado pela Teoria Histórico-Cultural do bielo-russo Lev Semienovich Vigotski (1896-1934), com interlocução com a Teoria da Assimilação de Piotr Yakovlevich Galperin (1902-1988). Orientou-se pelo pressuposto de que o ensino estruturado, segundo os princípios da Teoria Histórico-Cultural, converge para o processo de formação dos conceitos científicos, promovendo o desenvolvimento das funções complexas, da estruturação da consciência e da constituição da personalidade. Partiu-se da seguinte questão: como se dá o processo de construção dos conceitos científicos, especificamente no ambiente de uma sala de aula? A parte empírica da pesquisa foi desenvolvida na cidade de Corumbá (MS), numa escola estadual, com três turmas do primeiro ano do ensino médio e suas respectivas professoras. Foram acompanhadas e analisadas diversas sequências didáticas na disciplina de biologia. O método empregado foi o dialético. Os instrumentos de coleta de dados foram: entrevistas semiestruturadas, questionários e diário de campo. A pesquisa trouxe evidências de que as questões relativas à motivação, à contextualização dos conceitos, à função da avaliação e ao papel do ensino médio na educação básica compõem aspectos fundamentais a serem considerados no processo ensinoaprendizagem dos conceitos científicos. Também demonstrou que a Teoria Geral da Atividade constitui um valioso recurso para a análise do processo educativo, especialmente aquele relacionado à formação de conceitos científicos.

\section{Palavras-chave}

Teoria da Atividade; Formação de Conceitos; Adolescência; Ensino Médio; Teoria Histórico-Cultural; Teoria da Assimilação. 


\section{Abstract}

Moraes, Ronny Machado; Eisenberg, Zena Winona (Advisor). The teaching and learning of scientific concepts in high school in the conception of the Cultural-Historical Theory. Rio de Janeiro, 2019. 205p. Tese de Doutorado - Departamento de Educação - Pontifícia Universidade Católica do Rio de Janeiro.

The main objective of the study was to investigate the process of building scientific concepts, specifically in a classroom environment, using the methodology of the General Theory of Activity from the Russian psychopedagogist Alexei Nikolaivich Leontiev (1903-1979), supported by the Historical-Cultural Theory from Byelorussian Lev Semienovitch Vigotski (18961934), with interlocution with the Assimilation Theory from Piotr Yakovlevich Galperin (1902-1988). The assumption that conducted the research was that structured teaching, according to the principles of Historical-Cultural Theory, favors the process of building scientific concepts, by promoting the development of higher psychological functions, the structuring of consciousness and the formation of personality. It started with the following question: how does the process of constructing scientific concepts, specifically, in the classroom environment, take place? The empirical part of the study was developed in the city of Corumbá (Mato Grosso do Sul, Brazil), in a state school, in three first-grade secondary school classes and their teachers. Some teaching sequences where accompanied and analyzed during the Biology classes. The method used was dialectical; the data collection instruments were: semi-structured interviews, questionnaires and field diaries. The study provided evidence that the issues related to motivation, contextualization of concepts, evaluation function and the role of secondary education in basic education are fundamental aspects to be considered in the teaching-learning formation process of scientific concepts. It also demonstrated that the General Theory of Activity constitutes a valuable resource for the analysis of the educational process, especially the one related to the formation of scientific concepts.

\section{Keywords}

Theory of Activity; Formation of Concepts; Adolescence; High school; Cultural Historical Theory; Theory of Assimilation. 


\section{Sumário}

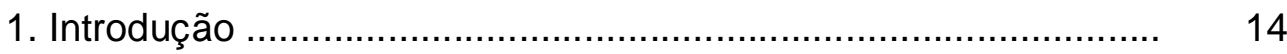

2. O contexto socioeconômico e o ensino médio no Brasil .............. 27

2.1. Educação e desigualdade social .......................................... 27

2.2. Origem da educação média no Brasil num contexto de

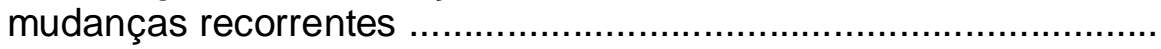

2.2.1. Ensino médio: da profissionalização compulsória à

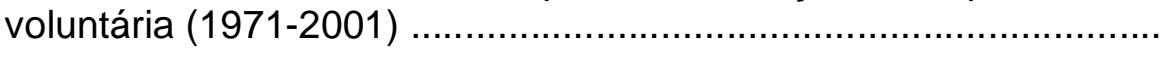

2.2.2. O ensino médio e o projeto de desenvolvimento nacionalpopular $(2003-2016)$...............................................................

2.2.3. A 'surpresa' da contrarreforma do ensino médio .................. 45

3. O desenvolvimento humano sob a perspectiva de Vigotski ........ 49

3.1. O desenvolvimento humano e o período cognominado

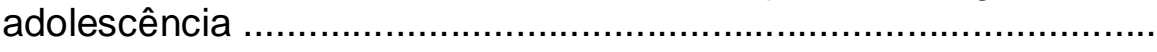

3.2. Teoria histórico-cultural e a trajetória da formação de conceitos

3.2.1. A trajetória que leva à formação dos conceitos ................... 67

4. Teoria da atividade de A.N. Leontiev e a aprendizagem escolar . 72

4.1. Estrutura geral da atividade externa e interna ....................... 77

4.2. O papel do motivo e os processos motivacionais ................... 83

4.3. Contribuições da Teoria da Assimilação das Ações Mentais de P. Ya. Galperin e N. F. Talízina para a formação de conceitos ..

5. A construção do percurso metodológico ….............................. 96

5.1. Instrumentos utilizados na coleta de dados ........................... 96

5.2. Perfis dos grupos examinados: estudantes e professoras ....... 99

5.3. Descrição e delimitação do local da pesquisa: cidade e a escola

5.4. Sistematização dos dados através do ATLAS Ti ..................... 112

5.5. Análises e inferências ........................................................ 114 
6. Considerações finais

7. Referências bibliográficas ....................................................... 184

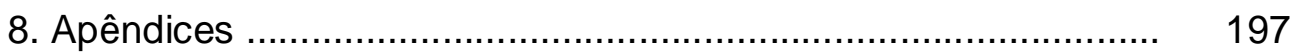

2.2. Apêndice $A$ - Questionário referente à infraestrutura da instituição de ensino ............................................................... 197 2.3. Apêndice B - Questionário relativo ao perfil das professoras .. 198

2.4. Apêndice C - Roteiro de entrevista semiestruturada (professoras e estudantes) .................................................. dos estudantes ...........................................................................

200 202 


\section{Lista de tabelas}

Tabela 1 - Prevalência de estudos envolvendo o ensino médio...............22

Tabela 2 - Distribuição das turmas por período.......................................99

Tabela 3 - Estudantes afirmaram que já foram ou se encontram casados. 101

Tabela 4 - Acesso à internet em suas residências..............................102

Tabela 5 - Alunos que já foram reprovados no Ensino Médio................102

Tabela 6 - Pessoas que dividem a casa com o estudante. ...................104

Tabela 7 - Involução do número de estudantes matriculados no ensino médio no período de dez anos em Corumbá MS. 109 


\section{Lista de quadros}

Quadro 1 - Formação acadêmica e atividade profissional das professoras. 106

Quadro 2 - Famílias e seus códigos derivadas das entrevistas, observações e questionários............................................................115 


\section{Lista de figuras}

Figura 1 - Gráfico da distribuição das DTs em Ensino de Biologia conforme focos temáticos ao longo das quatro décadas examinadas na

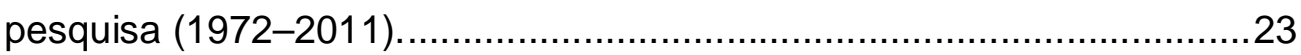

Figura 2 - Gráfico mostra a distribuição das faixas etárias por turma....100

Figura 3 - Gráfico mostra o número de alunos que possuem computador em casa. 101

Figura 4 - Gráfico indica número de alunos que trabalham, já trabalharam ou que ainda não trabalham. 103

Figura 5 - Gráfico mostra a distribuição de renda das famílias dos estudantes. 104

Figura 6 - Croqui da escola. 112

Figura 7 - Rede semântica de "C1" e suas correlações. 116

Figura 8 - Rede semântica exibe a importância das aulas contextualizadas (conhecimento e vida cotidiana). 131

Figura 9 - Rede semântica de "C2" e suas subcategorias 145

Figura 10 - Rede semântica exibe a importância da motivação na dinâmica da aula.

Figura 11 - Rede semântica representa a C4 "Questões vinculadas ao papel do ensino médio" e as referidas subcategorias vinculadas. 162

Figura 12 - Rede semântica formada a partir de C4 "Questões vinculadas à avaliação". 169 
(FAUSTO Abre a Bíblia no Evangelho de S. João)

No princípio era o Verbo. É esta a letra expressa; aqui está... No sentido é que a razão tropeça. Como hei-de progredir? Há 'í quem tal me aclare? O Verbo!! Mas o Verbo é coisa inacessível. Se apurar a razão, talvez se me depare para o lugar de Verbo um termo inteligível...

Ponho isto: No princípio era o Senso... Cautela nessa primeira linha; às vezes se atropela a verdade e a razão co'a rapidez da pena; pois o Senso faz tudo, e tudo cria e ordena?...

É melhor No princípio era a Potência... Nada! Contra isto que pus interna voz me brada. (Sempre a almejar por luz, e sempre escuridão!) ... Agora é que atinei: No princípio era a ação.

FAUSTO poema dramático de GOETHE Tradução de António Feliciano de Castilho Universidade de Aveiro - PT 


\section{Introdução}

O interesse pela temática da formação de conceitos é decorrente das minhas inquietações como docente na educação básica, pois atuei no ensino fundamental e especialmente no nível médio durante mais de uma década. Exerci a docência na rede pública no ensino fundamental II, ensinando ciências; na rede privada, no ensino médio, ministrei a disciplina de biologia. Nesses anos de atuação no magistério, na educação básica, deparei-me com situações bemsucedidas de aprendizagem, mas também com alguns insucessos. Considero como insucesso o baixo desempenho dos estudantes em avaliações e trabalhos, o abandono e a reprovação.

Foram justamente essas situações de insucessos que me levaram a questionar e hipotetizar sobre a eficácia, ou no caso, a ineficácia do processo ensino-aprendizagem, o que me suscitava alguns questionamentos, como: Qual a razão da não aprendizagem, do abandono e da reprovação dos estudantes, sobretudo da escola pública? O que se passava no processo de ensinoaprendizagem, que fazia com que determinados estudantes tinham mais sucesso que outros? Com o aumento da experiência decorrente da atividade docente e os estudos realizados, percebi que o fenômeno era complexo e multideterminado.

Outro aspecto relevante que constatei durante a minha atividade docente estava relacionado aos modos de organização e de apresentação do conteúdo aos estudantes, principalmente através de livros didáticos (manuais didáticos) e das tais apostilas. O que eu percebia era que, no ensino fundamental, a organização do conteúdo era menos rígida, permitindo-me aprofundar os conteúdos. Já no ensino médio, sobretudo na escola privada, as aulas seguiam um currículo rígido. As apostilas traziam o conteúdo organizado por aula. A minha função se restringia a seguir um roteiro pré-estabelecido, apresentando e discutindo os conceitos científicos ali exibidos, rigidamente 'cronometrados'.

Naquele momento, eu já percebia o quanto o currículo era engessado, com características genéricas e com pouco aprofundamento conceitual, baseado numa lógica organizacional ao mesmo tempo rígida e utilitarista. Outra constatação era de que o ensino oferecido na escola pública tinha características mais aligeiradas em relação àquele oferecido pela escola privada, desvelando-se uma perceptível dualidade. Apesar de notar que um ensino bem elaborado e planejado geralmente 
levava à formação de conceitos, fato era que muitos estudantes não chegavam a construir os conceitos científicos da disciplina que eu ministrava. Tal realidade me provocava uma grande inquietação. Outra verificação era em relação ao papel do ensino médio, claramente voltado para a preparação dos estudantes para o Exame do Vestibular e, posteriormente para o $\operatorname{ENEM}^{1}$, através de um ensino essencialmente propedêutico, fundamentado em ensinamentos genéricos, pouco aprofundados e a-históricos.

A título de exemplo, os conteúdos das apostilas dos dois primeiros anos do ensino médio eram completamente revisados no terceiro ano, para que os alunos apreendessem e retivessem uma grande quantidade de conceitos, por meio da repetição. Essa orientação era própria dos diversos tipos de sistemas apostilados. Algo análogo ocorria na escola pública de ensino médio, em que também trabalhei como professor contratado. A minha impressão era de que a escola parecia uma linha de montagem. Cada professor contribuía, de forma cronometrada, com uma peça na 'montagem' do produto.

A aflição oriunda da minha prática pedagógica e das minhas reflexões levou-me a cursar o Mestrado em Educação, elegendo o tema relacionado à aprendizagem de conceitos, que explorei com fundamentação em uma perspectiva da psicologia cognitivista. Nesse tipo de abordagem, enfatiza-se a organização do conhecimento na mente e as melhores maneiras de sua retenção e evocação, ou seja, a aprendizagem é fundamentada nas teorias do processamento da informação. Para Mizukami (1986, p. 59), o termo 'cognitivista' refere-se aos psicólogos que investigam os denominados 'processos centrais' do indivíduo, que são dificilmente observáveis, tais como a organização do conhecimento, o processamento de informações, os estilos de pensamento, etc.

No mestrado, meu estudo restringiu-se a olhar o fenômeno da aprendizagem de conceitos a partir da relação entre o ensino e o desempenho dos estudantes e da proposição e testagem de uma metodologia de ensino baseada no uso de novas tecnologias (ensino através de mapas conceituais). O objetivo geral

\footnotetext{
${ }^{1}$ O Exame Nacional do Ensino Médio - ENEM é uma prova realizada pelo Instituto Nacional de Estudos e Pesquisas Educacionais Anísio Teixeira - INEP, autarquia vinculada ao Ministério da Educação do Brasil, criada em 1998. Seu objetivo é selecionar estudantes para o Ensino Superior.
} 
da minha dissertação foi testar uma metodologia de ensino baseada nos princípios da Teoria da Aprendizagem Significativa ${ }^{2}$.

Continuando a narrar a minha trajetória profissional, fui selecionado em concurso público como docente de uma universidade pública federal, ministrando a disciplina de Psicologia do Desenvolvimento e da Aprendizagem ${ }^{3}$ em diversos cursos de licenciatura. Durante as aulas, revisitei os autores que havia estudado no mestrado e, a partir de um distanciamento, comecei a pensar o fenômeno da aprendizagem de conceitos sob outro ponto de vista. Com o ingresso no doutorado via programa DINTER/PUC-RJ, concebi a pesquisa, objeto desta tese, voltada ao tema da aprendizagem de conceitos fundamentada na perspectiva histórica e cultural.

O relato mostra o quanto as questões da minha atividade pedagógica foram importantes na construção do tema de pesquisa, tanto no mestrado quanto no doutorado. Guardadas as devidas proporções, as questões são convergentes. Uma das diferenças que aponto foi o amadurecimento das minhas fundamentações teórico-metodológicas, sobretudo no aprofundamento das ideias ligadas ao materialismo histórico e dialético, sumamente relevantes para a compreensão do fenômeno em tela.

Hoje percebo que as ideias de historicidade, totalidade, contradição e mudança, oriundas da dialética de Marx, fazem parte do meu movimento intelectual na busca de significados e na construção de sentidos dos fenômenos vinculados ao processo educativo. Destarte, é certo que os estudos que realizei e as experiências que adquiri durante minhas vivências produziram em mim mudanças fundamentais como estudante e pesquisador ${ }^{4}$.

É nossa intenção, através desta introdução, apresentar brevemente o tema, a questão de pesquisa e os objetivos, a sua relevância e os fundamentos teóricometodológicos, que serão retomados nos capítulos seguintes, com maior aprofundamento. A indagação fundamental que nos guiou em nossa investigação foi: como se dá o processo de construção dos conceitos científicos, especificamente no ambiente de uma sala de aula? Outras questões, não menos

\footnotetext{
${ }^{2}$ Cf. D. P. Ausubel e J. D. Novak, Psicologia Educacional, Rio de Janeiro: editora interamericana (1980), p. 22-23.

${ }^{3}$ Em alguns cursos a disciplina é nomeada Psicologia da Educação.

${ }^{4}$ Até aqui eu utilizei a primeira pessoa, por entender que a minha trajetória acadêmica e profissional é algo particular. No decorrer desta tese será utilizada a primeira pessoa do plural, pois em nossa compreensão a pesquisa é um trabalho coletivo.
} 
importantes, foram: O que são os conceitos? Como se formam os conceitos? Quais os tipos de atividades pedagógicas, de fato, contribuem para a formação de conceitos? Qual o papel dos aspectos motivacionais na formação dos conceitos? Por que os verdadeiros conceitos são formados somente na adolescência? O que consideramos adolescência? Qual o papel da etapa do ensino médio no Brasil? Uma das questões que consideramos fundamentais foi: qual a capacidade explicativa da Teoria Geral da Atividade de A. N. Leontiev em relação ao desenvolvimento de conceitos científicos? Esperamos explicar e responder a todos esses questionamentos ao longo dos capítulos desta tese.

A intenção inicial era realizar um estudo empírico que envolveria seis escolas estaduais da cidade de Corumbá-MS. No entanto, em concordância com a orientadora, o estudo ficou circunscrito a uma única escola, pelos seguintes motivos: naquele momento, ela era considerada a maior escola do estado de Mato Grosso do Sul, em número de alunos; tinha três turmas de primeiros anos, com três professoras distintas; pela facilidade de deslocamentos do pesquisador, haveria a oportunidade de maior permanência no campo empírico. A opção pelo primeiro ano do ensino médio deu-se pelo fato de que os estudantes estão iniciando uma importante etapa da educação básica ${ }^{5}$.

Em nosso entendimento, a formação de conceitos, especialmente os científicos, processa-se num ambiente específico, que é a sala de aula, com regras muito particulares. Para a sua investigação e apreensão, é preciso tomar uma série de cuidados. O processo está interligado a um complexo sistema educacional, que possui uma forma específica de organização, e que também é determinado por questões ligadas à cultura, à política e à economia. Portanto, trata-se de um fenômeno com múltiplos determinantes.

Outro desafio é a própria conceituação de conceito. Segundo Sforni (2003, p. 5), os professores possuem distintos entendimentos do que seja conceito e seu modo de assimilação, o que acaba por influenciar a organização e a prática pedagógica. Assim, conhecer o sistema educacional e os sujeitos envolvidos, que são os professores e estudantes, é fundamental para a compreensão do processo de ensino-aprendizagem de conceitos científicos, considerando que todo o processo

\footnotetext{
${ }^{5}$ A Lei de Diretrizes e Bases da Educação Brasileira - LDB, através do Artigo $4^{\circ}$, define que a educação básica está organizada da seguinte maneira: pré-escola, ensino fundamental e ensino médio.
} 
ocorre numa totalidade maior que a sociedade, influenciada pelas decisões políticas, os caminhos da economia e a cultura.

Desse entendimento surgiu a proposta do presente estudo, que é amparado na Teoria Geral da Atividade, de Alexei Nikolaivich Leontiev (1903-1979), sustentado pela Teoria Histórico-Cultural, estabelecida por Lev Semionovich Vigotski (1896-1934), com interlocução com as ideias desenvolvidas por Piotr Yakovlevich Galperin (1902-1988) e Nina Fiódorovna Talízina (1923).

Um dos pressupostos mais importantes da Teoria Histórico-Cultural é de que a passagem da atividade prática dos animais à atividade humana ocorreu pela mediação de meios externos, sendo os mais importantes os instrumentos e os signos, com a intenção de satisfazer certas necessidades. Sob essa perspectiva, tanto os instrumentos quanto os signos são produtos da cultura e agem como mediadores entre o homem e o mundo. A palavra é o mais importante dos signos, pois constitui o principal meio de relação entre os seres humanos.

Este estudo propôs-se a examinar a formação de conceitos como uma ação inserida na atividade de ensino-aprendizagem, ou seja, enquanto ela ocorre, ou mais exatamente, em seu processo. O processo de ensino-aprendizagem se traduzse em um complexo sistema de atividades, composto de ações e operações, objetivando a transmissão de um conjunto de conhecimentos historicamente construídos pela humanidade. As questões relativas ao problema da formação de conceitos trazem em si uma importância teórica e outra prática.

Em relação à questão de ordem teórica, a formação de conceitos é uma atividade psicológica exclusivamente humana, que permite ao sujeito representar a realidade para elaborar, conduzir e regular o funcionamento do seu psiquismo e, consequentemente, da sua conduta. É através dos conceitos que o indivíduo passa a construir conhecimento sobre o seu mundo e a sua realidade. Portanto, o problema da formação de conceitos configura-se como uma das questões centrais da psicologia e um dos temas mais importantes para a educação.

As questões práticas referem-se à compreensão do que ocorre na relação entre o professor e o estudante e entre ambos e o conhecimento no processo de ensino-aprendizagem. Martins (2013) confirma que o ensino de conceitos ocupa a centralidade do ensino; são eles os responsáveis pelo desenvolvimento dos processos funcionais superiores. A educação escolar é vista pela autora como imprescindível na constituição dos processos especificamente humanos. 
A questão central que norteia esta tese é que a compreensão do processo de formação de conceitos científicos, por parte do professor, favorece um ensino efetivo e qualitativamente superior. Defendemos a ideia de que a Teoria Geral da Atividade possui o potencial de analisar o processo de formação de conceitos. Assim, nosso objetivo geral foi compreender como se dá o processo de formação de conceitos científicos, especificamente no ambiente de uma sala de aula, acompanhando e analisando diversas sequências didáticas.

A atividade do ser humano que the propicia o conhecimento do mundo e o seu autorreconhecimento dá-se pelo reflexo da realidade em sua consciência. O homem não somente percebe o mundo através do sentido, mas o representa na sua consciência. A atividade e a consciência, portanto, estão dialeticamente interligadas; não há dualidade entre os dois sistemas. O trabalho é realizado por meio de um sistema de atividades que somente são possíveis através da consciência das necessidades humanas. A atividade, neste caso, está diretamente ligada à origem da necessidade - é ela que desencadeia todo o sistema de atividades.

Por se tratar de uma psicologia de base marxista, estamos cientes das diversas interpretações e entendimentos, inclusive em relação às controvérsias sobre as ideias de L. S. Vigotski e de A. N. Leontiev. Distintos estudiosos avaliam que houve uma ruptura nas ideias desenvolvidas por Vigotski e seus continuadores. As dúvidas recaem especialmente sobre A. N. Leontiev. Reconhecemos que há um litígio em relação à produção teórica desses autores e defendemos o debate. A disputa manifesta-se na medida em que se questiona até que ponto a Teoria da Atividade de Leontiev amplia e desdobra, ou distorce as ideias básicas de L. S. Vigotski. Nossa posição é de que se trata de duas posições, duas linhas de pesquisa dentro de uma mesma escola: uma tem como unidade de análise o signo; a outra, a atividade. Sob uma perspectiva dialética, são complementares, e não excludentes.

A seguir, trataremos de conceituar o conceito, com as justificativas e a relevância teórica e prática decorrentes da investigação. Em seguida, comentaremos sobre a metodologia utilizada. Os aspectos teóricos e metodológicos serão detalhados no capítulo cinco.

Sob a perspectiva adotada, os sujeitos são determinados através das relações sociais, das múltiplas atividades e das interações. Nesses contextos de 
atividades e reciprocidades socioculturais, com as mediações socioculturais, os indivíduos edificam as suas representações e compartilham os conceitos. Como a escola é um ambiente de socialização, o seu papel fundamental é promover o deslocamento do estudante, imerso nas experiências da vida cotidiana e das informações meramente perceptuais e imediatas do senso comum, para um modo de pensar diferente, tendo como referência o conhecimento científico. Para Vigotski, as relações que ocorrem nesse ambiente são também determinantes das personalidades que se constituem através das vivências ${ }^{6}$. É a partir dessas vivências que surgem, nos estudantes, formas mais avançadas de estruturação do psiquismo.

Pela sua qualidade, o conhecimento científico possui uma lógica de gênese e organização que difere da lógica do senso comum. Portanto, a aprendizagem de conceitos exige dos estudantes a apropriação de uma lógica de organização do que é diferente do conhecimento cotidiano. A escola é o local onde os estudantes, preferencialmente, entram em contato com um grande e variado conjunto de conceitos hierarquicamente organizados, a partir de diferentes áreas do conhecimento, que compõem o chamado currículo. Esse conjunto conceitual, em princípio, deveria ampliar e transformar as relações que os estudantes estabelecem com a sua realidade, ao mesmo tempo em que transformam a forma e o conjunto de suas atividades intelectuais.

Nossa opção pela análise dos processos mentais da prática educativa, pela direção psicológica e didática, não significa descartar os múltiplos determinantes da atividade de ensino-aprendizagem que ocorre na escola e nem a opção pelo subjetivismo integral. Em conformidade com Marx, nas famosas Teses sobre Feuerbach (1999, p. 3), Tese III - “os homens são produto das circunstâncias e da educação, e de que, portanto, homens modificados são produto de circunstâncias diferentes e de educação modificada",

\footnotetext{
${ }^{6}$ Prestes (2010) considera o conceito de vivências - perejivani -como fundamental na obra de Vigotski, mas que aparece, no entanto, traduzida de forma arbitrária, tanto em livros no Brasil, quanto em outros países. A perejivani, não diz respeito a uma particularidade da criança e nem ao ambiente social em que ela se encontra, mas à relação entre os dois. A autora considera que Leontiev, diferentemente de Vigotski, tem uma visão que ela considera paralelista, uma vez que entende que o ambiente social e as suas peculiaridades interagem, mas existem de forma independente. A vivência é como um "prisma" que determina o papel e a influência do meio no desenvolvimento psicológico. O sujeito não é simplesmente produto do meio, mas de suas relações com os seus elementos e suas vivências peculiares.

${ }^{7}$ Cf. <http://www.dominiopublico.gov.br/download/texto/ma000081.pdf>
} 
Sob essa perspectiva a escola, em uma sociedade escolarizada como a nossa, é o lócus primordial com a função de propiciar e potencializar o desenvolvimento dos indivíduos que ali se encontram. Daí a proposição de um ensino baseado em uma didática desenvolvimental ${ }^{8}$. Para a concepção históricocultural, a aprendizagem e o desenvolvimento são vistos como uma única unidade. Ela parte do entendimento de que a 'educação de qualidade' não intenciona somente formar força de trabalho qualificada ou memorizar conceitos; fundamentalmente, é um processo que se dirige ao desenvolvimento do pensamento, da linguagem, da memória mediada, da percepção, da atenção dirigida, dos sentimentos e emoções, dos motivos e das necessidades. Essas funções são designadas de funções psicológicas superiores, uma vez que são fundamentalmente produzidas através das relações sociais e da imersão do sujeito na cultura.

A psicologia histórico-cultural entende que é por meio da instrução que se produz o desenvolvimento psíquico e, assim, se constrói a consciência, que por sua vez produz a personalidade, tratando-se de processos simultâneos. O papel da instrução formal, segundo a teoria, está relacionado à promoção do desenvolvimento humano na sua multidimensionalidade, conforme já explicitado.

Prestes (2010, p. 66) destaca que um dos primeiros artigos sobre a formação de conceitos no Brasil foi divulgado em uma revista sobre o ensino de química, em outubro de $1986^{9}$. E assinala que alguns pesquisadores já haviam tido contato com as ideias da escola de psicologia soviética nos anos 1970, a partir da publicação do famoso e controvertido texto de Vigotski (1962) Thought and Language, editado no Brasil como Pensamento e Linguagem.

Acerca da produção acadêmica sobre a formação de conceitos científicos, ressaltamos os estudos realizados por Teixeira \& Teixeira $(2011,2012,2017)$,

\footnotetext{
${ }^{8}$ A didática desenvolvimental parte da concepção vigotskiana de que o bom ensino é aquele que se adianta ao desenvolvimento, ou seja, ele se dirige às neoformações psicológicas que estariam em vias de serem concluídas. A expressão 'ensino desenvolvimental' é a tradução de Developmental teaching, da mesma maneira que aparece na tradução do russo para o inglês no livro de Davidov publicado na Rússia no ano de 1966, Problems of developmental teaching.

9 O título do artigo é "O ensino de conceitos em química I: sobre o conceito de substância", publicado na revista, ciência e cultura, no 38, em 10/10/1986. Figuravam como autores: Romeu Rocha-Filho, Mário Tolentino, Roberto Ribeiro da Silva, Elizabeth Tunes e Emílio Carlos Poderoso de Souza. O artigo se encontra na Tese de Doutorado de Prestes, Z., Quando não é quase a mesma coisa: análise das traduções de Lev Semionovich Vigotski no Brasil: repercussões no campo educacional. $\mathrm{O}$ acesso pode ser feito através do link <https://www.cepae.ufg.br/up/80/o/ZOIA_PRESTES_-_TESE.pdf?1462533012.>
} 
Teixeira e Megide (2012) e Teixeira (2008, 2012), em teses e dissertações relativas ao ensino de biologia no Brasil, nos últimos 40 anos (1972 a 2011) ${ }^{10}$. Os autores trazem elementos que corroboram com a nossa constatação de que os estudos sobre a formação de conceitos são escassos, se comparados a outros temas. Segundo os autores, há uma prevalência de investigações dedicadas ao ensino médio e superior, sobre diversos temas, conforme mostra a tabela a seguir (TABELA 1).

\section{Tabela 1 - Prevalência de estudos envolvendo o ensino médio.}

Tabela 3. Distribuição por décadas das 1000 DTs em Ensino de Biologia conforme nível de ensino investigado (1972-2011).

\begin{tabular}{lcccccccccc}
\hline Nivel de Ensino & EI & EF & EM & EF/EM & ES & EF/ES & EM/ES & G & O+NI & EJA \\
\hline $1972-1980$ & 0 & 1 & 7 & 0 & 9 & 1 & 0 & 0 & 0 & 0 \\
$1981-1990$ & 0 & 7 & 8 & 3 & 16 & 0 & 1 & 2 & 1 & 0 \\
$1991-2000$ & 0 & 25 & 37 & 18 & 40 & 0 & 6 & 11 & 2 & 0 \\
$2001-2010$ & 3 & 99 & 245 & 43 & 203 & 4 & 37 & 42 & 2 & 15 \\
2011 & 1 & 15 & 42 & 5 & 36 & 1 & 5 & 4 & 0 & 3 \\
\hline Totais & 4 & 147 & 339 & 69 & 304 & 6 & 49 & 59 & 5 & 18 \\
Siglas: EI: Educação Infantil; EF: Ensino Fundamental; EM: Ensino Médio; ES: Educação Superior; G: Geral; \\
O+NI: Outro + Nivel Não-Identificado; EJA: Educação de Jovens e Adultos. Fonte: elaborado pelos autores.
\end{tabular}

\section{Extraído de: TEIXEIRA E MEGIDE NETO, 2017.}

Conforme os autores, houve um expressivo aumento da produção acadêmica sobre o ensino de biologia a partir dos anos 1990. A partir de 2006, ocorreu um aumento significativo, o que, segundo o levantamento, coincidiu com a criação de diversos cursos de mestrado profissional na área.

Quanto às tendências temáticas e metodológicas que caracterizam o ensino de biologia nesse período de 40 anos, os autores elencam a prevalência dos seguintes temas: ensino aprendizagem; formação de professores; características dos professores; características dos alunos; formação de conceitos; história, filosofia e sociologia da ciência; educação em espaços não formais e divulgação científica; recursos didáticos; educação ambiental; educação em saúde, linguagens e discurso; Alfabetização científica e tecnológica, abordagens; questões curriculares, programas e projetos; avaliação; diversidade e educação inclusiva; pesquisa e produção científica; e organização do espaço escolar.

\footnotetext{
10 O estudo está disponível no link: <https://seer.ufmg.br/index.php/rbpec/article/view/3055/6091>.
} 
Dentre esses temas, destacam-se: ensino-aprendizagem $(19,6 \%)$, recursos didáticos (16,2\%); características dos professores (11,9\%); formação de professores (11\%); características dos alunos (10,7\%); e questões curriculares, programas e projetos $(9,7 \%)$. Essas seis áreas corresponderam a $80 \%$ da produção acadêmica. A temática da formação de conceitos não foi significativa no conjunto da produção acadêmica no período analisado (FIGURA 1).

Figura 1 - Gráfico da distribuição das DTs em Ensino de Biologia conforme focos temáticos ao longo das quatro décadas examinadas na pesquisa (1972-2011).

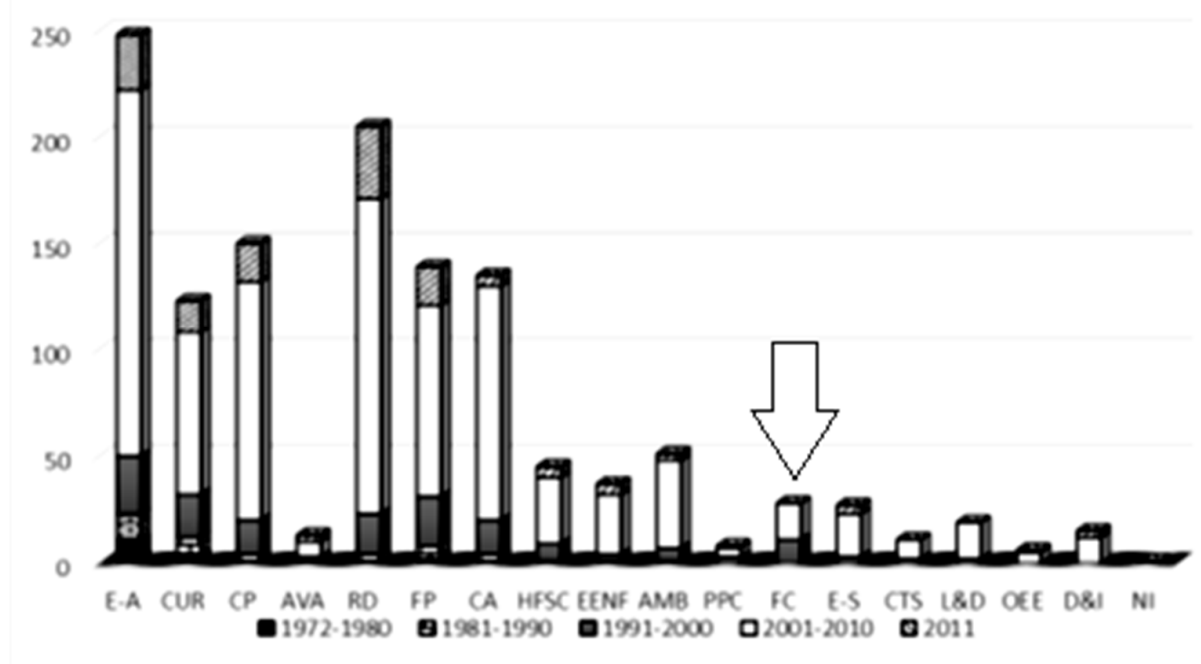

Extraído de: TEIXEIRA E MEGIDE NETO, 2017.

Nota: EA: Ensino-A prendizagem; CUR: Questões Curriculares, Programas e Projetos; CP: Características dos Professores; AVA: Avaliação; RD: Recursos Didáticos; FP: Formação de Professores; CA: Características dos Alunos; HFSC: História, Filosofia, Sociologia da Ciência; EENF: Educação em Espaços não Escolarizados; AMB: Educação Ambiental; PPC: Pesquisa e Produção Científica; FC: Formação de Conceitos; E-S: Educação em Saúde; L\&D: Linguagem e Discurso; OEE: Organização do Espaço Escolar; D\&I: Diversidade e Educação Inclusiva; NI: Foco Temático não identificado.

Em pesquisa que realizamos na plataforma da CAPES, no período de 2014 a 2016, filtrada por teses na área de educação, com base nos descritores "Teoria da Atividade, Leontiev", encontramos quatro trabalhos relacionados à temática especificamente. Somente um se referia à Teoria da Atividade envolvendo o ensino médio. Por outro lado, com o descritor "Formação das Ações Mentais por Estágios, Galperin", localizamos um número maior de publicações, majoritariamente nas áreas de matemática, química e física. 
Em um importante estudo realizado por Sforni (2013) sobre o estado da arte no tocante à utilização da Teoria Histórico-Cultural, baseado nos Anais dos ENDIPE $^{11}$, nos anos de 2006, 2008 e 2010, observamos um crescimento das publicações à época, muito embora esse número fosse tímido. Comparado aos outros referenciais adotados pelos pesquisadores, certamente era muito pequeno. Geralmente, os trabalhos tinham como sujeitos os professores ou os estudantes da educação básica. Muitos deles assumiam um viés 'construtivista' ou 'sócio construtivista', sinal de uma possível distorção da Teoria Histórico-Cultural. No texto a seguir, Duarte comenta sobre essa vertente:

O construtivismo sempre se apresentou no Brasil como se estivesse trazendo ideias inteiramente novas para a educação, não assumindo sua filiação ao movimento escolanovista. Nesse aspecto, os construtivistas brasileiros não foram fiéis ao mestre J. Piaget, pois este nunca escondeu que considerava sua perspectiva, no terreno epistemológico e psicológico, afinada com os chamados "métodos ativos" da Escola Nova. (DUARTE, 2001, p. 86)

O autor não vê compatibilidade entre a teoria de Vigotski e o construtivismo. No seu entendimento, há uma estreita relação com o movimento denominado escolanovista. O escolanovismo tinha como lema 'aprender a aprender', ou seja, considerava o papel do professor como secundário, cabendolhe apenas organizar as situações didáticas; o aluno aprendia a aprender. Além disso, ao considerar a impossibilidade de transmitir os conteúdos, o trabalho se limitava a propor as atividades didáticas de pesquisa. Ou seja, a aprendizagem se confundia com a pesquisa. Abordaremos esse assunto com maior profundidade no capítulo II, seção 2 .

Passamos, assim, ao delineamento desta pesquisa. Trata-se de abordagem qualitativa, fundamentada na dialética de Marx e Engels, que analisou o processo de formação de conceitos a partir das condições estabelecidas historicamente no ensino médio. $\mathrm{O}$ estudo foi realizado com três turmas de primeiros anos em uma escola estadual de ensino médio. As turmas (T1, T2 e T3) e suas respectivas

\footnotetext{
${ }^{11}$ ENDIPE - Encontro Nacional de Didática e Prática de Ensino. O presente estudo pode ser acessado em sua íntegra através do link <http://www.histedbr.fe.unicamp.br/acer_histedbr/jornada/jornada11/artigos/9/artigo_simposio_9_ 832_martasforni@uol.com.br.pdf>
} 
professoras (P1, P2 e P3) foram acompanhadas pelo pesquisador durante um semestre letivo. A coleta de dados foi feita por meio da observação participante, com registro em diário de campo; os instrumentos utilizados foram entrevistas semiestruturadas com professores e estudantes, além de questionário socioeconômico. A pesquisa documental envolveu a análise de leis, resoluções e outros documentos referentes à organização do ensino médio no Brasil. Os dados da pesquisa foram sistematizados com apoio do programa ATLAS.Ti.

$\mathrm{Na}$ análise das atividades desenvolvidas no processo ensino-aprendizagem por um grupo de estudantes adolescentes e suas respectivas professoras numa dada escola de ensino médio, procuramos compreender quais delas contribuem fundamentalmente para a construção dos conceitos científicos. Abordamos as atividades a partir de um contexto maior da organização da educação básica no Brasil e das concepções de ensino das professoras expressas nas ações aplicadas. Vigotski (2001) considera que é necessário estudar a atividade prática social da criança como recurso para se estudar a mente.

Esta tese está organizada em quatro capítulos. O primeiro capítulo, intitulado $O$ contexto socioeconômico e o ensino médio no Brasil, insere duas seções e cinco subseções. A primeira seção traz um breve relato acerca das condições históricas e econômica no Brasil, procurando relacionar com a etapa do ensino médio no Brasil. A segunda seção, dividida em três subseções, expõe um breve relato da organização e as principais mudanças que o ensino médio sofreu ao longo de sua história. A relevância do capítulo reside no fato de que o objetivo foi produzir um arcabouço histórico de como o ensino secundário se constituiu, a fim de revelar o contexto em que a pesquisa ocorreu. Em cada um dos momentos, o contexto social e político do país e as concepções pedagógicas adotadas são objeto de discussão.

O segundo capítulo, intitulado $O$ desenvolvimento humano sob a perspectiva de Vigotski, dedica-se à Teoria Histórico-Cultural com maior profundidade, abordando os seus pressupostos teórico-metodológicos e enfocando os estágios de desenvolvimento humano, especialmente a adolescência. $\mathrm{O}$ capítulo está divido em duas seções e uma subseção. A primeira trata da concepção de adolescência; a segunda, do processo de formação de conceitos segundo a teoria vigotskiana. 
O terceiro capítulo, com o nome de Teoria da atividade de A. $\mathbf{N}$. Leontiev e a aprendizagem escolar, detalha a Teoria da Atividade de Leontiev, considerada aqui como prosseguimento das ideias de Vigotski, destacando o seu potencial frente ao estudo do sistema de atividades de ensino. O capítulo está dividido em três seções. A primeira seção explicita a estrutura geral da Teoria da Atividade de A. N. Leontiev. Na segunda seção, o destaque direciona-se ao papel dos motivos para a manutenção da atividade. E na terceira seção o foco recai sobre a Teoria da Assimilação de Galperin e sua contribuição na formação dos conceitos.

Finalmente, o quarto capítulo, A construção do percurso metodológico, está dividido em cinco seções. A primeira seção revela os instrumentos utilizados na coleta de dados; a segunda seção aborda os perfis acadêmicos e a atividade profissional das professoras; na terceira, apresenta-se a descrição do local da pesquisa; a quarta discute a sistematização dos dados obtidos; e a quinta trata das análises e inferências.

Nas Considerações finais, retomamos a teoria que nos embasou. Fazemos uma sinopse dos estudos realizados e dos resultados obtidos, e relatamos as possíveis implicações para a atividade de ensino-aprendizagem. Também levantamos as lacunas deixadas pelo nosso trabalho, ressaltando os estudos que ainda precisam ser efetivados para consubstanciar os nossos achados. 


\section{2 \\ O contexto socioeconômico e o ensino médio no Brasil}

\section{1 Educação e desigualdade social}

Muito embora o Brasil tenha experimentado altas taxas de crescimento econômico e social na primeira década dos anos 2000, isso pouco contribuiu para resolver as enormes desigualdades nas áreas sociais, econômicas e educacionais. Conforme preconiza o artigo 214 da constituição de 1988, o Brasil deveria empenhar-se em estabelecer um Plano Nacional de Educação - PNE, com duração plurianual, com os seguintes objetivos: erradicação do analfabetismo; universalização do atendimento escolar; melhoria na qualidade do ensino; formação para o trabalho; e promoção da formação humanística, científica e tecnológica. Fato é que, decorridos quase 20 anos, com dois planos de educação 2001-2010 e 2011-2020, poucos foram os avanços. Apesar do acesso à educação básica ter sido resolvido, sobretudo no ensino fundamental, o país convive com altíssimas taxas de evasão, repetência e defasagem idade-série, que têm se revelado especialmente no ensino médio.

Neste breve panorama da educação no Brasil, discorremos sobre alguns dos principais indicadores que pensamos possuir relação com as condições socioeconômicas vividas pelos brasileiros. Partimos dos dados estatísticos obtidos pela Pesquisa Nacional por Amostra de Domicílios - PNAD Contínua, do Instituto Brasileiro de Geografia e Estatística - IBGE, relativos ao ano de $2017^{12}$. Esses dados foram correlacionados com as informações produzidas pela Organização das Nações Unidas para a Educação, a Ciência e a Cultura UNESCO. Consideramos os seguintes dados: analfabetismo; nível de instrução e anos de estudo; e a frequência à educação profissional, por entendermos que corroboram para explicar alguns dos problemas socioeconômicos e culturais brasileiros, ou seja, podem se configurar como causa e/ou efeito. Esse processo, portanto, se dá num círculo vicioso.

\footnotetext{
12 Os dados referem-se à PNAD-contínua (2017) e podem ser acessados através do link https://www.ibge.gov.br/estatisticas-novoportal/sociais/trabalho/17270pnadcontinua.html?edicao $=21073$
} 
Por exemplo, a taxa de analfabetismo no Brasil, em pesquisa de 2017, com pessoas de 15 anos ou mais, foi estimada em 7\% da população (11,5 de pessoas analfabetas), o que revelou que ela é persistente em idades mais avançadas. Entre as pessoas com 60 anos ou mais, a taxa foi de 19,3\%, sendo 1,1 pontos percentuais a menos que em 2016. Ainda assim, a relação entre analfabetismo e a idade demonstra o seu caráter estrutural, ou seja, mesmo em queda, ela persiste mais alta em idades avançadas. Segundo dados da Organização das Nações Unidas para a Educação, a Ciência e a Cultura - UNESCO - ONU, o Brasil está entre os dez países do mundo com as mais altas taxas de analfabetismo. O analfabetismo de pessoas com 15 anos ou mais, além de revelar a educação de baixa qualidade recebida, também está intrinsicamente relacionado ao baixo nível de crescimento econômico e social.

O indicador 'nível de instrução' capta o nível educacional de cada pessoa, independentemente da permanência nos cursos por ela frequentados. No Brasil, a proporção de pessoas de 25 anos ou mais de idade que finalizaram a educação básica obrigatória, ou seja, que concluíram, no mínimo, o ensino médio, passou de 45\%, em 2016, para 46,1\%, em 2017. Apesar do aumento constatado na comparação entre os dois anos, ele ainda está aquém dos países tidos como de alto nível educacional. Conforme relatório da UNESCO voltado ao monitoramento global (2013/14), o aumento do nível de educação reduz a pobreza e fomenta empregos e o crescimento. Outro aspecto expressivo no tocante ao nível de instrução no Brasil é o fato de que tanto o gênero quanto a escolaridade afetam significativamente o rendimento dos trabalhadores ${ }^{13}$. Esses estudos apontam que, por exemplo, "para cada ano de instrução da mãe, seus filhos passam 0,32 a mais na escola" (PNAD - Contínua, 2014, p. 23).

A frequência à educação profissional, seja na graduação tecnológica, seja em nível técnico e tecnológico, tem sido apontada como um fator conectado às condições de atividade socioeconômicas. Em 2017, entre os 7,9 milhões de estudantes do ensino superior de graduação no Brasil, 776 mil frequentavam cursos tecnológicos, correspondendo a $9,8 \%$ do total de estudantes do ensino superior. Naquele ano, 56,6 milhões de pessoas estavam aptas a frequentar um curso técnico de nível médio, mas somente $3,5 \%$ desse total estavam

\footnotetext{
${ }^{13}$ Conferir em https://www.oecd.org/brazil/Education-at-a-glance-2015-Brazil-in-Portuguese.pdf
} 
frequentando, ou seja, quase 2 milhões de pessoas. Nos anos de 2016 e 2017, cujo momento econômico foi de declínio da ocupação, a educação e a qualificação profissional não ganharam espaço entre as pessoas de 18 a 29 anos. O período foi caracterizado por altas taxas de desocupação dos jovens e pela baixa procura por cursos profissionalizantes - houve um processo de estagnação econômica e social.

No período da pesquisa, o Brasil convivia com altas taxas de analfabetismo, com baixa escolarização e de formação técnica profissional, questões que atingiam, sobretudo, a classe trabalhadora. Os dados são um recorte da situação social e econômica vivida pelo Brasil e revelam as enormes disparidades de uma sociedade dividida em classes. A inclusão de milhões de jovens na vida social e econômica do país é um desafio.

O ensino médio caracteriza-se como um dos 'gargalos' da educação básica, que passou por recorrentes mudanças em sua organização e finalidade, sempre à mercê dos fatores sociais, políticos e principalmente econômicos, como veremos nas próximas seções. Finalizando esta breve introdução, registramos que a educação pode ser vista tanto como uma forma de romper com a lógica do acúmulo de capital, como também como de manutenção da sua lógica. Assim, a escola não é somente reprodutora do capital, mas é também o lugar privilegiado de resistência ao seu avanço. Para uma compreensão de como se estrutura o nível médio e seu papel na educação básica, trataremos mais especificamente desse tema nas seções a seguir.

\section{2 \\ Origem da educação média no Brasil num contexto de mudanças recorrentes}

No Brasil, a educação secundária recebe o nome de ensino médio; é a derradeira etapa da educação básica. ${ }^{14} \mathrm{O}$ ensino médio compõe o percurso que concentra o maior número de estudantes que se encontram na fase da adolescência propriamente dita. $\mathrm{O}$ trajeto entre a primeira e a terceira série do ensino médio é

\footnotetext{
${ }^{14}$ A partir da constituição de 1988, no artigo Art. 208 - O dever do Estado com a educação será efetivado mediante a garantia de: I - educação básica obrigatória e gratuita dos 4 (quatro) aos 17 (dezessete) anos de idade, assegurada inclusive sua oferta gratuita para todos os que a ela não tiveram acesso na idade própria. (Redação dada pela Emenda Constitucional no 59, de 2009) (Vide Emenda Constitucional n ${ }^{\circ} 59$, de 2009). Fonte: http://www.mpgo.mp.br/portalweb/hp/10/docs/constituicao_federal_de_1988_-_da_educacao.pdf>
} 
estimado entre os 15 e os 17 anos de idade ${ }^{15}$. Essa trajetória é bastante sinuosa, com altas taxas de evasão, retenção e abandono.

A hipótese que nos guia neste tópico é que o ensino médio atual apresenta claramente uma dualidade que se distingue pela oferta de duas modalidades de ensino e pela segmentação e diferenciação dos processos educativos que tratam as diferentes classes sociais de forma desigual. No atual contexto, a intenção é aprofundar tal dualidade, por isso defendemos que compreender a sua história é uma forma de entender as mudanças do ensino secundário na atualidade e propor alternativas de mudanças.

Conforme Kuenzer (2017, p. 338), a dualidade adquire diversas formas, oriundas do regime de acumulação flexível ${ }^{16}$, como a ideia de aprendizagem flexível, cuja lógica se baseia na distribuição desigual do conhecimento e a formação de profissionais flexíveis, que acompanhem as mudanças advindas da dinamicidade da produção científico-tecnológica da contemporaneidade. Esse regime, ao aprofundar as diferenças de classe social, tem exacerbado a dualidade estrutural, a ponto de refletir sobre a escola e a formação dos estudantes, principalmente no nível do ensino médio.

Para Ciavatta (2011, p. 31), a formação flexível ocorreria por meio da fragmentação curricular que, supostamente, proporcionaria ao trabalhador oportunidades de se atualizar ou se requalificar, demandado por mudanças na produção e/ou na situação de emprego. Dessa maneira, o trabalhador seria capaz de renovar permanentemente as suas competências, por diversas oportunidades, até mesmo em cursos de currículos flexíveis.

Entendemos que a escola é o lugar privilegiado para a aquisição do saber elaborado historicamente pela humanidade. Isso implica que esse saber seja socializado de forma igualitária entre as classes sociais, o que se opõe veementemente aos direcionamentos posicionados em termos econômicos e políticos. A apropriação dos conceitos científicos é uma das condições fundamentais para que o sujeito faça frente às questões de classe social. Nesta

\footnotetext{
${ }^{15}$ Estimativas de fluxo escolar a partir do acompanhamento longitudinal dos registros de aluno do Censo Escolar do período 2007-2016. Fonte: INEP - 2017. Cf. <http://download.inep.gov.br/educacao_basica/censo_escolar/notas_estatisticas/2017/notas_estatis ticas_censo_escolar_da_educacao_basica_2016.pdf>

${ }^{16}$ Para maiores aprofundamentos sobre a ideia de regime de acumulação flexível indicamos a obra "Adeus ao trabalho? Ensaio sobre a metamorfose e a centralidade do mundo do trabalho", de Ricardo Antunes (1995).
} 
tese, abordamos a aquisição de conceitos científicos como instrumento para a compreensão da realidade e a construção de personalidade dos sujeitos. Com isso, propomos resistência às investidas das ideias hegemônicas da classe dominante e alternativas a essa desigualdade, o que demanda a autoconsciência que se produz na compreensão dialética da realidade.

Conforme Saviani (2013, p. 67), se a escola não permite o acesso a esses instrumentos, os trabalhadores ficam bloqueados e impedidos de ascender ao nível da elaboração do saber, embora continuem, pela sua atividade prática real, a contribuir para a produção do saber. $O$ saber sistematizado continua a ser propriedade privada a serviço do grupo dominante.

O nosso foco, neste tópico, é elencar os principais marcos regulatórios e normativos da educação secundária no Brasil, inclusive no âmbito da educação geral, nos termos das principais leis e das ideias pedagógicas da época em que foram propostas, revelando, sempre que possível, o ambiente sociopolítico em que foram aprovadas, com a finalidade de demonstrar a relação entre o ensino secundário e as novas formas de organização do capital.

De acordo com Batista e Lima (2011, p. 36), o ensino secundário passou a existir efetivamente em 1942, com a reforma da educação conhecida como Reforma Capanema ${ }^{17}$, a partir do Decreto-lei ${ }^{\circ} 4.244$, de 9 de abril de $1942^{18}$, que foi a lei orgânica do ensino secundário. Essa reforma deu-se no período de 1934 a 1945, quando o ministro Gustavo Capanema esteve à frente do Ministério da Educação.

O Brasil vivia, à época, sob a ditadura do então presidente Getúlio Vargas (1930-1945), período que ficou conhecido como a Era Vargas. A reforma introduziu mudanças significativas no ensino secundário, que passou a ser oferecido em dois ciclos. O primeiro era formado pelo ginasial, com duração de quatro anos; o segundo, o colegial, pelo clássico ou científico ${ }^{19}$, com duração de

\footnotetext{
${ }^{17}$ Foi uma reforma do sistema educacional brasileiro realizada durante a Era Vargas (1930-1945), sob o comando do ministro da educação e saúde Gustavo Capanema. A reforma, de 1942, foi marcada pela articulação junto aos ideários nacionalistas de Getúlio Vargas e seu projeto políticoideológico, implantado sob a ditadura conhecida como 'Estado Novo'.

${ }^{18}$ Decreto sancionado pelo então presidente Getúlio Dorneles Vargas, em 9 de abril de 1942. Disponível para acesso através do link <http://www2.camara.leg.br/legin/fed/declei/19401949/decreto-lei-4244-9-abril-1942-414155-publicacaooriginal-1-pe.html>

${ }^{19}$ Através do decreto-lei $n^{\circ} 4.244$ - de 9 de abril de 1942, artigo $4^{\circ}$, o curso clássico e o curso científico, cada qual com a duração de três anos, terão por objetivo consolidar a educação ministrada no curso ginasial e bem assim desenvolvê-la e aprofundá-la. No curso clássico, concorrerá para a formação intelectual, além de um maior conhecimento de filosofia, um acentuado estudo das letras antigas; no curso científico, essa formação será marcada por um estudo maior de ciências.
} 
três anos. O currículo era dividido em três grandes áreas: línguas (português, grego, latim, francês, inglês e espanhol); ciências e filosofia (matemática, física, química, biologia, história geral e do Brasil, geografia geral e do Brasil, filosofia); Artes (desenho).

As mudanças que a reforma Capanema introduziu viabilizaram também a criação dos serviços de formação industrial e comercial.

Tendo substituído Francisco Campos no Ministério da Educação, a partir de julho de 1934, Gustavo Capanema deu sequência ao processo de reforma educacional interferindo, nos anos 30, no ensino superior e, a partir de 1942, nos demais níveis de ensino por meio das "leis orgânicas do ensino", também conhecidas como "Reformas Capanema", abrangendo os ensinos industrial e secundário (1942), comercial (1943), normal, primário e agrícola (1946), complementados pela criação do SENAI (1942) e do SENAC (1946). (SAVIANI, 2004, p. 5)

A chamada 'Reforma Capanema' significou, portanto, um marco na criação do ensino médio, ou secundário de segundo ciclo, conforme ficou conhecido. Segundo Kuenzer (1991, p. 7), a reforma promoveu a unificação dos já existentes cursos complementares de preparação para ingresso no curso superior (pré-jurídico, pré-técnico e pré-politécnico), em um único curso chamado de Colegial, com duração de três anos. No entanto, a dualidade persistiu e continuou com a criação e o aperfeiçoamento de uma 'rede' de escolas de formação técnica específica, hoje conhecida como sistema $\mathrm{S}^{20}$.

A reforma também igualou os cursos técnicos existentes (normal, agrotécnico, comercial técnico, industrial técnico) no mesmo nível do Colegial. Para a autora, essa mudança permitiria que estudantes oriundos dos cursos profissionalizantes tivessem acesso ao curso superior. Além disso, essa adequação deu-se devido a uma "demanda bem definida da divisão social e técnica do trabalho organizado e gerido pelo paradigma taylorista/fordista como resposta ao

\footnotetext{
${ }^{20}$ Termo que define o conjunto de organizações das entidades corporativas voltadas para o treinamento profissional, assistência social, consultoria, pesquisa e assistência técnica, que além de terem seu nome iniciado com a letra $\mathrm{S}$, têm raízes comuns e características organizacionais similares. Fazem parte do sistema S: Serviço Nacional de Aprendizagem Industrial (Senai); Serviço Social do Comércio (Sesc); Serviço Social da Indústria (Sesi); e Serviço Nacional de Aprendizagem do Comércio (Senac). Existem ainda os seguintes: Serviço Nacional de Aprendizagem Rural (Senar); Serviço Nacional de Aprendizagem do Cooperativismo (Sescoop); e Serviço Social de Transporte (Sest). Fonte: <https://www12.senado.leg.br/noticias/glossariolegislativo/sistema-s >
} 
crescente desenvolvimento industrial" e se complementou com a criação do já citado sistema S. No mesmo período, foram criadas as Escolas Técnicas Federais.

De acordo com Saviani ${ }^{21}$ (2004), “a regulamentação do ensino ia sendo feita conforme as urgências definidas pelos grupos que assumiam o controle político do país". Enquanto as reformas de Francisco Campos se dirigiram ao ensino superior, secundário e comercial, as de Capanema se voltavam às leis orgânicas, a começar pelo ensino industrial, depois o secundário e atingindo, na sequência, os ensinos comercial, normal, primário e agrícola.

Finalmente, chegamos ao que consideramos a terceira grande reforma do período. Kuenzer (2007, p. 14) expõe que "apenas em 1961 é aprovado o decreto Lei $\mathrm{n}^{\circ} 4.024^{22}$ que foi a primeira Lei de Diretrizes e Bases da Educação Nacional". Pela primeira vez apareceu, na legislação, a articulação completa entre os níveis fundamental, médio e o profissional, até então separados. Com essa unificação, os cursos oferecidos pelo SENAI e SENAC puderam se equivaler aos níveis fundamental $\left(1^{\circ} \mathrm{grau}\right)$ e técnico $\left(2^{\circ} \mathrm{grau}\right)$. Com a lei, também houve certa flexibilização dos currículos, sendo facultadas às escolas seguir os currículos rigidamente padronizados. Assim, cada sistema de ensino tinha autonomia de montar o seu próprio currículo, desde que mantivesse o núcleo comum, com as disciplinas básicas: português, história, geografia, matemática e ciências.

Kuenzer (1991, p. 85) explica que, em decorrência do "desenvolvimento dos setores secundários e terciários da economia, [eles] acabaram por viabilizar o reconhecimento da legitimidade de outros saberes, não só os de cunho geral, na etapa que se caracteriza como tradicional nova, do ponto de vista do princípio educativo". A partir daí, a educação secundária passou a mesclar um projeto pedagógico humanista clássico, com alternativas profissionalizantes. No entanto, segundo a autora, "não se altera a essência do princípio educativo tradicional, que é a existência de dois projetos pedagógicos distintos, definidos pela divisão técnica e social do trabalho de formar trabalhadores instrumentais e intelectuais

\footnotetext{
${ }^{21}$ Cf. Trecho extraído do texto A Escola Pública Brasileira no Longo Século XX (1890-2001) Disponível em: <http://sbhe.org.br/novo/congressos/cbhe3/Documentos/Coord/Eixo3/483.pdf> Acesso em: 15 jun. 2018

${ }^{22}$ Esta primeira Lei de Diretrizes e Bases da Educação Nacional, chamada de LDB. Esta lei foi promulgada em 20 de dezembro d 1961, pelo então presidente da república João Goulart. O acesso ao texto original pode ser feito através do link <http://www2.camara.leg.br/legin/fed/lei/19601969/lei-4024-20-dezembro-1961-353722-publicacaooriginal-1-pl.html>
} 
através de sistemas distintos", voltados a prover os quadros de trabalhadores para a indústria, que estava se estruturando naquele momento.

Por fim, ressaltamos que tal divisão ainda permanece sobre bases muito semelhantes ao período já mencionado. Atualmente persiste essa diferenciação entre o ensino oferecido pelas escolas privadas, com ensino propedêutico, frequentadas pelas classes médias e as públicas, voltadas ao mercado de trabalho, majoritariamente frequentadas pelos trabalhadores mais pobres. Ainda de acordo com a autora, "a mudança produzida pela Lei 4024/61 não supera a dualidade estrutural, posto que permanecem duas redes, e a reconhecida socialmente continua a ser a que passa pelo secundário, sem sombra de dúvidas trouxe um avanço para a democratização do ensino" ${ }^{23}$.

\subsection{1 \\ Ensino médio: da profissionalização compulsória à voluntária (1971- 2001)}

Após o Golpe Militar ocorrido em abril de 1964, foi proposta e aprovada uma nova reforma do ensino, atingindo de maneira especial o ensino secundário. Essa reforma veio com a Lei $n^{0} 5.692 / 71,{ }^{24}$ que objetivava promover a adequação da legislação às novas exigências. Analisamos, aqui, dois importantes documentos decorrentes dessa, os pareceres $\mathrm{n}^{\circ} 45 / 72$ e 76/75, ambos relacionados à profissionalização $^{25}$.

A justificativa para tal reforma era de que o país, em 'pleno crescimento', necessitava de mão de obra especializada para atuar no mercado de trabalho. $\mathrm{O}$ Brasil vivia um período do chamado 'nacional desenvolvimentismo' e do 'milagre econômico'. Com o aporte de dinheiro externo, grandes obras estavam sendo erigidas. O período do regime militar permaneceu de 1968 até 1985.

Batista e Lima (2011, p. 37) expõem que, nesse período, ocorreu uma guinada do ensino, após a promulgação das novas Diretrizes e Bases da Educação Nacional, promovendo a equivalência entre os níveis secundário propedêutico e profissionalizante. $\mathrm{O}$ ensino propedêutico representado pelo colegial foi

\footnotetext{
${ }^{23}$ Ibid, p. 14.

${ }^{24}$ A Lei 5.692/71 foi promulgada pelo então presidente Emílio G. Médici, em 11 de agosto de 1971. O seu objetivo era fixar as diretrizes e bases para o ensino de $1^{\circ}$ e $2^{\circ}$ graus.

${ }^{25}$ Cf. Em O ensino profissional: o grande fracasso da ditadura, de Luiz Antônio Cunha. Acesso pelo link <http://www.scielo.br/pdf/cp/v44n154/1980-5314-cp-44-154-00912.pdf>
} 
substituído pela obrigatoriedade da habilitação profissional para todos os que cursassem o que passou a ser chamado ensino de $2^{\circ}$ grau. Este excerto de Saviani especifica melhor a nossa posição:

A orientação geral traduzida nos objetivos indicados e a referência a aspectos específicos, como a profissionalização do nível médio, a integração dos cursos superiores de formação tecnológica com as empresas e a precedência do Ministério do Planejamento sobre o da Educação na planificação educacional, são elementos que integrarão as reformas de ensino do governo militar. (SAVIANI, 2008, p. 295)

Uma das mais substanciais mudanças foi a separação em ensino de $1^{\circ}$ grau, com duração de oito anos e ensino de $2^{\circ}$ grau, com duração de três anos, que passou a ser chamado de ensino médio. $O$ ensino de segundo grau, quer proporcionado pelas escolas públicas ou privadas, deveria habilitar para o trabalho. Essa alteração foi alardeada pela propaganda da época como necessária ao desenvolvimento do país. Os alunos poderiam escolher parte das disciplinas que quisessem cursar. É possível fazer um elo entre a proposta implementada no período de ditadura militar e a atual mudança no ensino médio, conforme veremos a seguir.

A proposta inicial era oferecer mais de 100 habilitações, para que os alunos fizessem a sua escolha. Batista e Lima (2011, p. 39) mencionam que o Parecer $n^{\circ}$ 45/72 chegou a apresentar uma listagem de 52 habilitações plenas (nível técnico) e 78 habilitações parciais (nível auxiliar), totalizando um número de 130 possíveis cursos. A fim de realizar a suposta integração entre teoria e prática, o parecer também preconizava um estágio "como momento posterior ao processo de aprendizagem, e descolado deste, em que a síntese far-se-ia automaticamente". E assim, no final do curso, os alunos receberiam uma habilitação de caráter profissional. Para as autoras, a incorporação da categoria trabalho se fez pela lógica idealista, uma vez que o documento ressalta que a "preparação para a vida" deve ser construída sobre valores "espirituais" e "morais" e justifica "que tendo em vista que o mundo contemporâneo, caracterizado pelo avanço científico e tecnológico, estaria levado à materialização do homem": observamos aí uma posição de ordem essencialmente moral.

No entanto, para Ciavatta (2011, p. 170), a ditadura criou um novo 'álibi' para desviar os jovens do ensino superior e ideologizar a divisão social de classes 
com a formação profissional. Como mecanismos de 'driblar' essa intenção, as escolas particulares introduziram as disciplinas ditas 'instrumentais' e continuaram a preparar os seus estudantes para o ensino superior.

Ainda conforme Batista e Lima (2011, p. 39), os ensinos de $1^{\circ}$ e $2^{\circ}$ graus, conforme a lei, deveriam "proporcionar ao educando a formação necessária ao desenvolvimento de suas potencialidades como elemento de auto realização, qualificação para o trabalho e preparo para o exercício da cidadania" (art. $1^{\circ}$ da 5.692/71). Dessa maneira, a educação para o trabalho passou a fazer parte efetivamente do currículo dos dois níveis de ensino, o que não condiz com uma formação multilateral do indivíduo. Segundo nosso entendimento, o mercado passou a regular e organizar os currículos e os fins da educação nacional em consonância com a lei 5.692/71.

Para sintetizar os principais motivos que levaram à não implementação da Lei 5.692/71, no tocante ao ensino médio, recorremos novamente às autoras que, em linhas gerais, identificam: a contradição entre a forma da lei, o discurso ideológico e a proposta pedagógica; a inadequação da proposta às exigências do mercado de trabalho daquele período; e a ausência das condições materiais necessárias à implementação das mudanças (ibid.).

Diante da situação caótica em que se encontrava o ensino de segundo grau, houve uma 'nova' alteração na lei de Diretrizes e Bases da Educação, com a edição do parecer $n^{\circ} 76 / 75$. Segundo as autoras, nesse parecer "o relator retoma $o$ princípio da articulação entre educação geral e formação especial" e justifica a mudança pela necessidade de oferecer mais instruções ao MEC. De acordo com o parecer, o equívoco da norma anterior "reside no entendimento de que toda escola de $2^{\circ}$ grau deve transformar-se em escola técnico, quando não há recursos materiais, financeiro e humano".

O documento trazia outro conceito, o da formação profissionalizante básica, de caráter interinstitucional e geral que, mediando o $1^{\circ}$ e $3^{\circ}$ graus, levaria $o$ jovem a adquirir, na escola, os amplos princípios de formação profissional que seriam complementados na universidade ou no exercício da atividade profissional. Em decorrência da situação, o que o referido parecer concretamente fez, ao permitir a coexistência de todas as ofertas possíveis de ensino secundário e habilitações, foi mesmo acomodar a lei à realidade que já vigorava, de tal modo “que tudo permanecesse como antes de 1971". Para Saviani (2008, p. 43), a Lei 
5692/71 de tão flexível que era até "poderia até ser revogada sem ser revogada" (grifo nosso).

Desse modo, a antiga dualidade ressurgiu na legislação com toda a energia. De um lado, um ensino propedêutico voltado à preparação para o ingresso em cursos superiores e, do outro, as habilitações plenas, como meios de acesso ao mundo do trabalho. Para as autoras (ibid.), essa realidade não beneficiou os trabalhadores e seus filhos. O caráter formalista e academicista que caracterizou esse nível de ensino acabou por fragilizar ainda mais a educação profissionalizante, que passou a oferecer um ensino de baixa qualidade, inviabilizando aos seus destinatários a inclusão nos benefícios da produção e do consumo de bens materiais.

Decorridos dez anos da promulgação da lei $\mathrm{n}^{\mathrm{o}}$ 5.692/71, e como a promessa da lei não havia sido cumprida, houve muito descontentamento e críticas por parte dos estudiosos da educação. No ano de 1982, o congresso aprovou a Lei $\mathrm{n}^{\mathrm{o}} 7.044^{26}$, impondo uma 'nova' reforma no Ensino Secundário. A principal mudança foi em relação à profissionalização compulsória, preconizada pela lei anterior, que deixou de ser obrigatória. Nas palavras de Cunha (2017, p. 375 - grifo do autor), por meio da referida lei, “o ensino para o trabalho, no Ensino de Segundo Grau, poderia ensejar habilitação profissional”; assim, a opção por oferecer uma habilitação profissional "ficaria a critério de cada escola, conforme os interesses dos alunos".

Além disso, foi extinta a dicotomia existente entre formação geral e especial. Com essa nova concepção, poucas escolas ofereciam educação secundária profissionalizante. $\mathrm{O}$ que aconteceu foi que as instituições de ensino rapidamente adaptaram as suas grades curriculares e passaram a oferecer um ensino fundamentalmente propedêutico. A formação profissional ficou a cargo das poucas escolas federais e das organizações especializadas não governamentais.

Em 1988, foi promulgada a constituição denominada 'constituição cidadã $^{, 27}$. Acompanhando o processo de redemocratização, o artigo $n^{\circ} 208$ estabelece que é dever do Estado a educação em todos os níveis, segurando a

26 O acesso ao texto original está disponível através do link <http://www2.camara.leg.br/legin/fed/lei/1980-1987/lei-7044-18-outubro-1982-357120publicacaooriginal-1-pl.html>

${ }^{27}$ A expressão 'constituição cidadã' foi utilizada pelo Senador da República Ulisses Guimarães, durante a solenidade de sua aprovação, em 22 de setembro de 1988. A constituição de 88 marcou o período de redemocratização do Brasil. 
"progressiva extensão da obrigatoriedade e gratuidade ao ensino médio e o acesso aos níveis mais elevados de ensino, da pesquisa e da criação artística, segundo a capacidade de cada um”. Além dessa importante mudança, Kuenzer (2001) chama a atenção para o artigo $\mathrm{n}^{\circ} 205$, que considera um avanço ao reiterar a tríplice função da educação: o desenvolvimento pleno da pessoa, a preparação para o exercício da cidadania e a qualificação para o trabalho.

Concordamos com a autora: apesar do avanço proposto no texto constitucional que assegurava um Estado fortemente comprometido com as políticas sociais e educacionais, "ao estilo do Estado de bem-estar social, típico da etapa de desenvolvimento taylorista/fordista, este mesmo modelo já se tornava anacrônico em fase da globalização da economia e da reestruturação produtiva" ${ }^{28}$. O que havia era um antagonismo entre o que propunha a lei e as novas formas de organização dos modos de produção.

Posteriormente, em 1996, foi aprovada outra Lei de Diretrizes e Bases da Educação, Lei $n^{\circ} 9.394^{29}$, que ficou conhecida como a Lei 'Darcy Ribeiro' ${ }^{30}$. Foi a terceira LDB (as anteriores, já discutidas neste texto, foram a 4.024/61 e a 5.692/71). Esta última LDB determinou outra identidade ao ensino médio, passando a compreendê-lo como "uma etapa de consolidação da educação básica, de aprimoramento do educando como pessoa humana, de aprofundamento dos conhecimentos adquiridos no ensino fundamental para continuar aprendendo e de preparação básica para o trabalho e a cidadania".

Para o nosso estudo, frisamos algumas significativas mudanças dispostas na lei: primeiramente, trata-se da progressiva extensão da obrigatoriedade e gratuidade ao ensino médio; a segunda determina competência ao estado no oferecimento prioritário do ensino médio; a terceira se refere à disposição dos dois níveis escolares, educação básica (Educação Infantil, Ensino Fundamental e Médio) e superior; a quarta traz a preparação 'básica' para o trabalho (formação técnica não obrigatória), a cidadania, formação ética, autonomia intelectual e do pensamento crítico.

\footnotetext{
28 Ibid., p. 26-27.

29 O acesso ao documento original pode feito através do link <http://www2.camara.leg.br/legin/fed/lei/1996/lei-9394-20-dezembro-1996-362578publicacaooriginal-1-pl.html>

${ }^{30}$ Darcy Ribeiro (1922-1997) foi um antropólogo, escritor e político brasileiro, conhecido por engajamento em favor da luta dos índios e pela educação no país.
} 
Consideramos que uma das mais marcantes modificações no ensino médio do período concretizou-se com a resolução CEB n o 3, de 26 de junho de 1998, que instituiu as Diretrizes Curriculares Nacionais para o Ensino Médio - DCNEM. O documento trata dos princípios e fundamentos da organização curricular, das competências básicas a serem desenvolvidas, dos conteúdos e formas de tratamento dos conteúdos do ensino médio. À mesma época, também foram produzidos os Parâmetros Curriculares Nacionais do Ensino Médio - PCNEM/99 que, assim como as DCNEM/95, têm por finalidade listar os princípios relativos à estruturação do currículo, como a interdisciplinaridade, a contextualização e o currículo por competências.

Tanto as DCNEM/95 quanto os PCNEM/99 trazem propostas para a adequação da educação de nível médio às mudanças no setor produtivo e a preparação dos jovens para a flexibilização das relações de trabalho baseadas em um saber mínimo, sobretudo no desenvolvimento de sua capacidade de aprender a aprender. No Artigo $8^{\circ}$, que expõe sobre a interdisciplinaridade, o item V traz a seguinte redação "a característica do ensino escolar, tal como indicada no inciso anterior, amplia significativamente a responsabilidade da escola para a constituição de identidades que integram conhecimentos, competências e valores que permitam o exercício pleno da cidadania e a inserção flexível no mundo do trabalho" (RESOLUÇÃO CEB - 1998). Trazemos aqui as considerações de Kuenzer \& Grabowsk para esclarecer esta mudança:

[...] quando o capital disponibiliza para a classe trabalhadora, uma modalidade que já correspondeu, em outro regime de acumulação, ao seu projeto de dominação, o faz pela via precarizada. Assim, como o ensino médio de educação geral, caro à burguesia no regime de acumulação rígida, já não atende ao seu projeto no regime de educação flexível, ele passa a ser generalizado para a classe trabalhadora; para a classe dominante, no novo regime, é o conhecimento em ciência e tecnologia que passa a ser o diferencial. (KUENZER \& GRABOWSK, 2016, p. 25)

Através do trecho acima, os autores explicitam de forma inequívoca, que na sociedade de classes, o oferecimento de uma ou outra forma de ensino sempre estará relacionado às formas de organização do capital. Para a classe trabalhadora, geralmente se oferece uma forma já superada, enquanto que, para a classe 
dominante, se oferta uma forma de educação que mantém o seu domínio sobre a outra classe. Assim, através da Lei 9.394/96 e da DCNEM/98, que evidenciam a formação geral para o trabalho como um dos principais aspectos, isso se coaduna com a acumulação flexível.

Segundo Kuenzer,“a formação de subjetividades flexíveis, tanto do ponto de vista cognitivo quanto ético, se dá, predominantemente, pela mediação da educação geral", ${ }^{31}$ e "é por meio dela, disponibilizada de forma diferenciada por origem de classe, que os que vivem do trabalho adquirem conhecimentos genéricos que lhes permitirão exercer, e aceitar, múltiplas tarefas no mercado flexibilizado", Assim, a formação precarizada se dá para um trabalho que também é precário. As modificações na educação que ocorreram no período estavam em conformidade com as políticas neoliberais postas em prática.

A lei 9.394/96 foi a vencedora de uma disputa entre duas vertentes no parlamento brasileiro: de um lado, o grupo de parlamentares ligados ao pensamento da esquerda, defendendo um estado ampliado, para quem a educação deveria ser controlada por mecanismos de controle social; o outro grupo defendia o poder de regulação e organização centrado no estado. $O$ segundo grupo conseguiu impor a maior parte de suas propostas, prevalecendo os ideais neoliberais.

Ferreira (2017, p. 298) relata que, mesmo com os avanços provenientes da letra da lei, que propunha a articulação do ensino médio com a preparação para o trabalho, no decreto Lei $2.208 / 97^{32}$, editado ainda no governo de Fernando Henrique Cardoso (1995-2002), a junção foi novamente proibida, e o ensino médio voltou a assumir o caráter propedêutico e de dualidade. Isso, ainda segundo a autora, "aprofundou ainda mais a crise de identidade do ensino médio", mas, nomeadamente "forçou os alunos das classes populares, geralmente trabalhadores, a ficarem mais tempo em escolas estruturalmente precárias, tanto física quanto pedagogicamente". O excerto a seguir demonstra outros retrocessos:

\footnotetext{
${ }^{31}$ Ibid, 2016.

32 Acesso ao texto original através do link <http://www2.camara.leg.br/legin/fed/decret/1997/decreto-2208-17-abril-1997-445067publicacaooriginal-1-pe.html>
} 
[...] a partir de 1997, houve uma significativa expansão do ensino profissional privado no país, pois eram poucas as vagas públicas ofertadas em um cenário de altas demandas de qualificação profissional e altos índices de desemprego. (FERREIRA, 2017, p. 298)

A autora cita mais alguns retrocessos, como a expansão do ensino profissional privado. No entanto, a mais importante constatação é de que essa 'nova' reforma nada teve de novo. Foi uma repetição das propostas da Era Vargas, quando as ideais do escolanovismo dominaram a cena educacional. Para Saviani (2004, p. 8), esse terceiro período pedagógico produtivista da educação foi baseado na ideia do capital humano. A teoria do capital humano ${ }^{33}$ baseia-se na concepção de que o estoque de conhecimentos, habilidades, atitudes, valores e níveis de saúde potencializam a força de trabalho das diferentes nações. Tornou-se senso comum que aqueles países, ou famílias e indivíduos, que investissem em educação acabariam tendo um retorno igual ou maior que outros investimentos produtivos. Segundo Frigotto (2009, p. 69), “a educação se volta para a ideia de capital humano constitui-se na década de 1950, a partir da ideia de um trabalhador treinado, adestrado e educado e com saúde para se adaptar às exigências da produção mercantil e atingir a produtividade máxima”. Saviani (2004) define que esse ideário pedagógico "é mais um legado do século XX que persiste ainda na atualidade da educação brasileira".

\subsection{2 \\ O ensino médio e o projeto de desenvolvimento nacional-popular (2003-2016)}

Objetivando a uma melhor compreensão das principais reformas no ensino médio deste início de século XXI, é necessário evidenciar as principais mudanças no campo da política. Frigotto e Ciavatta (2003, p. 121) narram que, diante das disputas políticas em relação aos projetos de desenvolvimento para o Brasil desde o final do período de ditadura militar, no ano de 2002, venceu o projeto de

\footnotetext{
${ }^{33}$ Para maior aprofundamento, recomendamos o texto de Gaudêncio Frigotto - Contexto e Sentido Ontológico, Epistemológico e Político da Inversão da Relação Educação e Trabalho para Trabalho e Educação - Revista Contemporânea de Educação, vol. 10, n. 20, julho/dezembro de 2015.
} 
desenvolvimento nacional-popular, com a eleição de Luiz Inácio Lula da Silva ${ }^{34}$ (2002-2011), depois de quatro disputas.

Segundo Ferreti e Silva (2017, p. 123) as forças políticas que elegeram esse projeto estavam organizadas "num arco de alianças de matiz ideológicas ecléticas", com representantes das três tendências de desenvolvimento ${ }^{35}$ : liberal e/ou neoliberal, nacional desenvolvimentismo ou desenvolvimentismo conservador, e o desenvolvimento econômico nacional e popular. O governo iniciou comprometido em congregar os interesses dos diversos grupos que garantiram a sua eleição. Ele obteve sucesso e conseguiu governar o país por dois mandatos, além de eleger e reeleger a sua sucessora, Dilma Vana Rousseff, a primeira mulher a governar o país. Ela foi reeleita para um segundo mandato, mas não conseguiu terminar devido a um processo de impeachment ${ }^{36}$.

O processo ocorreu de maneira conturbada e repleta de dúvidas sobre a sua legitimidade, o que o levou a ser chamado de golpe midiático-parlamentar ${ }^{37}$. O vice, que contraditoriamente pertencia ao PMDB, partido que congrega distintos matizes ideológicos ligados à direita, dominava majoritariamente o congresso e articulou sistematicamente para que se desse o afastamento da presidente. As repercussões desse movimento levaram à presidência um político com ideais ligados ao pensamento liberal de direita.

Nesse período, houve importantes mudanças no campo educacional no Brasil, especialmente no ensino médio. De acordo com Ferrete e Silva (2017, p. 391) "no campo educacional, particularmente no que se refere ao ensino médio e à educação profissional, foram traçadas políticas que se encaminharam em direção muito diversa daquela posta em prática por seu antecessor”. Essas mudanças, segundo a autora, se deram "tanto no que diz respeito a postura teóricoepistemológica que serviu de base da política, quanto no seu desdobramento em termos de articulação entre ensino médio e a educação profissional”.

\footnotetext{
${ }^{34}$ Luis Inácio Lula da Silva, que governou o Brasil por dois mandatos, é oriundo do movimento sindical, tendo atuado no período de 1969 a 1975. Depois de liderar uma grande greve (greve dos 100 mil) ocorrida em 1979, Lula participou da criação do Partido dos Trabalhadores - PT.

${ }^{35}$ Para maiores aprofundamentos sobre essa classificação, recomendamos a leitura da obra de J. L. Fiori, "O nome aos bois. Instituto da Cidadania - Fundação Perseu Abramo". 2002.

${ }^{36}$ Processo de afastamento de cargo público ou destituição por crime de responsabilidade.

${ }^{37}$ Sobre a influência da mídia no afastamento da presidente Dilma Vana Roussef, recomendamos o trabalho de Liziane Guazina e Ébida Santos, intitulado "O impeachment de Dilma Rousseff nas capas da Folha de S. Paulo", [?]. Disponível em: <https://www.anpocs.com/index.php/papers-40encontro-2/gt-30/gt17-21/10760-o-impeachment-de-dilma-rousseff-nas-capas-da-folha-de-spaulo/file>
} 
Para os autores (ibid.), as principais diferenças foram as mudanças a partir da nova "DCNEM - Parecer CNE/Câmara de Educação Básica, (CEB) 05/2011 e Resolução $n^{\circ}$ CNE/CEB 02/2012 que teve como proposição principal a integração curricular em torno do eixo ciência, cultura, trabalho e tecnologia, e possuem como fundamento o princípio educativo do trabalho", ancoradas em bases teóricas muito diferentes da anteriores. Sobre a relação entre ensino médio e trabalho, a mudança diz respeito à "formação que leve à compreensão crítica do trabalho e da sociedade".

Uma das principais alterações que, a nosso ver, poderia significar um avanço nas políticas do ensino médio, mas que não chegou a ser implementada, foi o projeto de Reestruturação e expansão do ensino médio no Brasil ${ }^{38}$, instituído pela Portaria $n^{\circ}$. $1189 / 07$ e pela Portaria $n^{\circ}$. 386/08. Pelo projeto, seria criado o Programa Ensino Médio Nacional, como resultado das ações derivadas do Plano Nacional de Educação - PDE. O programa estava comprometido com as metas e objetivos do Plano Nacional de Educação - PNE. Consideramos o projeto inovador, porque propunha uma nova concepção do ensino médio, sob uma perspectiva abrangente de formação integral e estruturado na ciência, cultura e trabalho. Além da expansão do ensino médio integrado à educação profissional técnica de nível médio, o programa propunha a expansão mais ampla do ensino médio de formação integral. A proposta, entretanto, não foi implementada pelo governo de Rousseff.

Destacamos também a edificação dos dois Planos Nacionais de Educação - PNE. O primeiro, instituído através da Lei 10.172, de 9 de janeiro de 2001, foi elaborado em 1996, no governo Fernando Henrique Cardoso e vigorou de 2001 a 2010. Sua elaboração ocorreu em decorrência da Conferência Nacional de Educação - CONAE. O segundo, instituído através da Lei 13.005, de 25 de junho de 2014, ainda está em vigor. O PNE apresenta um plano de diretrizes e metas para a educação básica e superior.

O primeiro PNE constava de um 'ambicioso' plano de 20 objetivos e metas. Nossa análise tem como foco a oferta e as questões pedagógicas específicas que, no em nosso entendimento, estão relacionados à problemática deste estudo. Para Brandão (2011, p. 203), decorridos dez anos do PNE, a situação

\footnotetext{
${ }^{38}$ Para maiores aprofundamentos, recomendamos o acesso ao texto original. Disponível em: <http://portal.mec.gov.br/seb/arquivos/pdf/2008/interministerialresumo2.pdf >
} 
do ensino médio é pouco animadora. Em sua opinião, o próximo PNE não deve ser um rol de metas a serem alcançadas e nem uma 'carta de boas intenções', mas deve indicar uma ampliação e reorganização, seja de caráter propedêutico ou profissional, deixando claro que o que se pretende é a universalização desse nível de ensino. Essa universalização deve vir acompanhada de ações que conduzam à redução significativa do abandono, repetência e da distorção da idade série. Outro ponto diz respeito à proposição de novos modelos de organização didática, pedagógica e metodológica, sem que se caia novamente na dualidade.

Para Kuenzer (2010, p. 852), devido a uma avaliação consistente do PNE (2001-2010), por conta da inexistência de indicadores para acompanhar as metas e objetivos propostos para o decênio e da não explicitação dos mecanismos de financiamento, o atual PNE acabou se tornando um 'rol' de boas intenções, conforme já discutido.

Outra mudança relevante foi a implantação do Programa Nacional de Acesso ao Ensino Técnico e Emprego - PRONATEC (ibid., p. 499): "diferentemente do PNE, que surgiu da CONAE, o PRONATEC apareceu como política de governo implantada em 2011 que fomentou a destinação de recursos públicos às entidades privadas". O programa foi criado através da Lei $\mathrm{n}^{\circ}$ $12.513 / 11^{39} \mathrm{e}$, conforme os autores (ibid.), um dos seus problemas foi que "fomentou a destinação de recursos públicos às entidades privadas" e passou a "suprir as demandas do mercado de trabalho".

Igualmente, até 2015, "a maior parte da oferta de vagas do PRONATEC remetia-se à dualidade no processo formativo, ou seja, mais vagas eram destinadas à EPT desvinculadas da elevação da escolaridade" (LIMA e PACHECO, 2017, p. 501). Pensamos que os pontos negativos ofuscaram algumas iniciativas, como (ibid.) "a expansão da Rede Federal de Educação, Ciência e Tecnologia, que visa à implantação dos institutos federais no país" e a criação do "Programa Brasil Profissionalizado, que objetiva a ampliação da oferta e o fortalecimento da educação profissional integrada ao ensino médio nas redes estaduais". Essas movimentações na política do ensino médio e na educação profissional têm impacto na educação geral e na formação dos adolescentes,

${ }^{39}$ O Programa Nacional de Acesso ao Ensino Técnico e Emprego - PRONATEC foi instituído em 26 de outubro de 2011, através da lei $\mathrm{n}^{\mathbf{0}}$ 12.513. Disponível em: <http://www2.camara.leg.br/legin/fed/lei/2011/lei-12513-26-outubro-2011-611700normaatualizada-pl.pdf > 
porque traçam determinados perfis de formação, resultando no que hoje se tornou esse nível de ensino. Consideramos que o projeto não foi adiante devido às disputas políticas e ideológicas que, naquele momento, já estavam em curso, o que resultou na tomada do poder por um grupo ideológico rival.

\subsection{3}

\section{A 'surpresa' da contrarreforma do ensino médio}

No período em que a pesquisa estava em andamento, fomos surpreendidos com significativas mudanças no âmbito da política, da economia e da educação. No âmbito da política, em maio de 2016, o então vice-presidente da república Michel Temer assumiu a presidência após o afastamento de Dilma Roussef. No âmbito da educação, houve a chamada contrarreforma do ensino médio. Reputamos como oportuno o termo contrarreforma, pois, segundo afirmamos, já havia um projeto que visava a reestruturar o ensino médio. Soma-se a isso o fato de a proposta ter sido introduzida de maneira autoritária, com a edição da Medida Provisória 746/16. Segundo Kuenzer (2017, p. 333), a proposta atendeu aos interesses do setor privado e do Conselho Nacional de Secretários da Educação (CONSED) e "culmina com a promulgação da Lei $13.415 / 17^{40}$, que estabelece as novas diretrizes e bases para o ensino médio, nos termos dispostos pela referida Medida Provisória”, tendo sido incorporada à LDB nº 9.394/96.

Trazemos, aqui, a íntegra das justificativas apresentadas pelos defensores da proposta:

O baixo desempenho dos estudantes em Língua Portuguesa e Matemática, conforme o Índice de Desenvolvimento da Educação Básica (IDEB); a estrutura curricular com trajetória única para o conjunto de estudantes, cuja carga compreende 13 disciplinas, considerada excessiva e que seria a responsável pelo desinteresse e fraco desempenho; a necessidade de diversificação e flexibilização do currículo, tomando por modelo os países com melhor desempenho no Programa Internacional de Avaliação de Alunos (PISA); o fato de que menos de $17 \%$ dos alunos que concluem o ensino médio acessam a educação superior, e que cerca de $10 \%$ das matrículas estão na educação profissional como justificativa para a introdução do itinerário de formação técnica e profissional. (FERRETI E SILVA, 2017, p. 393)

\footnotetext{
${ }^{40} \mathrm{O}$ texto integral está disponível em <http://www2.camara.leg.br/legin/fed/lei/2017/lei-13415-16fevereiro-2017-784336-publicacaooriginal-152003-pl.html>
} 
Tecemos, aqui, algumas considerações acerca das justificativas dos defensores da contrarreforma. A primeira é que a proposta está baseada em levantamentos em larga escala, notadamente quantitativos, com ênfase em aspectos meritocráticos e de responsabilização; a segunda é que a proposta se atém especificamente ao currículo, deixando de lado aspectos de ordem material, como a estrutura física, laboratórios, quadras de esporte, transporte, contratação de professores, programas de formação continuada, etc.

Kuenzer (2017, p. 334) avalia que as mudanças "podem ser agrupadas em dois eixos: carga horária e organização curricular”. Em relação à carga horária, a lei determina a ampliação progressiva para 1.400 horas, devendo os sistemas de ensino atingir 1.000 horas em, no máximo, cinco anos. Com essa ampliação, no próximo quinquênio, mantidos os 200 dias letivos, a carga horária diária será de cinco horas, até atingir progressivamente sete horas diárias, ou seja, período integral. Não obstante, a autora chama a atenção para o fato de que a lei estabelece a carga horária máxima, mas não a mínima.

No que tange à organização curricular, a proposta cria os itinerários de estudo, com cinco possibilidades de percursos curriculares diferenciados, ‘à escolha' dos estudantes: (1) linguagens e suas tecnologias; (2) matemáticas e suas tecnologias; (3) ciências da natureza e suas tecnologias; (4) ciências humanas e sociais aplicadas; e (5) formação técnica e profissional.

Esses percursos (itinerários formativos) seriam organizados por meio de diferentes arranjos curriculares, podendo ou não estar integrados à formação comum, levando-se em conta o contexto local e as possibilidades dos sistemas de ensino. São duas disciplinas obrigatórias nos três anos do ensino médio: língua portuguesa e matemática; as demais, e entre elas artes, educação física, sociologia e filosofia, devem ser obrigatoriamente incluídas, mas não por todo o percurso, o que pode significar apenas um módulo de curta duração. A língua inglesa tem oferta obrigatória; os sistemas de ensino podem ofertar outras línguas, mas em caráter optativo. A lei traz também o ensino através de áreas do conhecimento, e não por disciplinas, exceto as duas já citadas.

A autora levanta alguns problemas em relação à dinâmica de formação, dentre elas o enrijecimento da formação, uma vez que os itinerários de ensino serão definidos pelos sistemas de ensino, conforme as suas condições de recursos, restringindo-se a possibilidade de escolha do estudante. Ou seja, uma coisa é o 
discurso; outra coisa, a prática. O estudante pode cursar mais de um itinerário, desde que haja vaga, e dependendo de seleção. Com isso, a possibilidade de sucesso está restrita a processos seletivos, o que pode levar à proliferação de cursos preparatórios.

Outra mudança analisada pela autora é no tocante à certificação das competências, que podem ser comprovadas através de demonstração prática, por experiências em trabalhos supervisionados ou adquiridas fora do ambiente escolar, o que permite reconhecer os conhecimentos tácitos do estudante. Para ela, essa forma de organizar atende ao princípio da flexibilização e promove a secundarização do conhecimento teórico.

Além disso, a flexibilização atinge os docentes, principalmente os das áreas da educação técnica e profissional, que podem ministrar conteúdos de áreas afins à sua formação ou à sua experiência profissional, desde que comprovado o seu notório saber, privilegiando o saber fazer. O que se pretende demonstrar, com as várias mudanças no ensino médio, é que as políticas formuladas e implementadas influenciaram naquilo que se espera desse nível de ensino.

Concordamos com Kuenzer (2017), que avalia que o ensino médio "desde 1930 assumiu uma forma específica de dualidade que se distingue pela oferta de diversas modalidades e pela segmentação e diferenciação dos processos educativos que tratam as diferentes classes sociais de forma desigual". Constatamos que essa forma de organização está ligada aos projetos políticos de cada momento histórico e possui relação com os aspectos econômicos de subordinação do Brasil ao desenvolvimento dos países imperialistas.

Analisando com cuidado o quadro das principais alterações, resumimos o período em três momentos. Em 1942, com a reforma Capanema, o ensino secundário foi organizado com a finalidade de atender às elites da época. Para os trabalhadores foram disponibilizados, através das leis orgânicas, os cursos profissionalizantes. Em 1961, houve o reconhecimento da integração entre o ensino profissional e o ensino regular de segundo ciclo (secundário). Entretanto, a dualidade permaneceu porque continuaram a existir dois ramos distintos de ensino. Em 1971, foi estabelecida a profissionalização compulsória no ensino de segundo grau. Em tese, todos passaram a ter a mesma trajetória nas escolas, mas isso, na prática, não aconteceu. 
Com a reforma de 1996, veio o anúncio da junção da formação do ensino médio e a formação para o trabalho, o que foi abortado imediatamente, fazendo com que o nível se tornasse essencialmente propedêutico. Como observamos, em determinados momentos houve resistências e tentativas de romper com a lógica dualista; no entanto, ela ainda persiste. Quanto às mudanças do ensino médio que ocorreram durante a pesquisa, entendemos ser prematuro expor conclusões, pois o movimento histórico se encontra em processo. Por isso podemos apenas conjecturar sobre ele. O cenário aponta para retrocessos e para novas e profundas alterações na educação básica. 


\section{O desenvolvimento humano sob a perspectiva de Vigotski}

Toda a história do desenvolvimento psíquico na idade de transição está constituída pelo crescimento das funções e pela formação de sínteses superiores, independentemente. Neste sentido, na história do desenvolvimento psíquico do adolescente predomina uma estrita hierarquia. As diversas funções (atenção, memória, percepção, voluntariado, pensativo) não se desenvolvem quando se trata de um "monte galhos" em um recipiente, nem sequer crescem como diversos galhos de uma mesma árvore unidos por tronco comum. No processo de desenvolvimento todas essas funções constituem um complexo sistema hierárquico onde a função central ou reitoria do desenvolvimento do pensamento, é a função de formação de conceitos. (VIGOTSKI, [?], p. 118)

Iniciamos este capítulo com a seguinte questão: por que adolescência, e não juventude? Conforme Leon (2004), os conceitos de adolescência e de juventude se superpõem. Ora constituem campos distintos, mas complementares, ora traduzem uma disputa por distintas abordagens. Conceitualmente, adolescência constitui um campo da psicologia evolutiva, inaugurada por Stanley Hall $(1904)^{41}$. O termo juventude é geralmente utilizado por estudiosos da área de sociologia, historiadores e demógrafos como categoria social, enquanto que o termo adolescência é usualmente adotado pelo campo da psicologia. Nossa opção é pelo conceito de adolescência, uma vez que foi amplamente utilizado por Vigotski e seus colaboradores, o que será mais bem explicitado adiante.

No Brasil, nos anos 1980, o termo adolescência se consagrou, ao orientar documentos oficiais como o Estatuto da Criança e do Adolescente (ECA) e fundamentar os documentos voltados às políticas públicas no campo da saúde, lazer, educação, prevenção à violência, etc. A concepção de adolescência adotada nesta tese refere-se essencialmente ao desenvolvimento cognitivo ou intelectual que se verifica no período, caracterizado pelo aparecimento de profundas mudanças qualitativas nas funções psicológicas.

A intenção deste capítulo é examinar com maior detalhamento a concepção de desenvolvimento e a etapa da adolescência, bem como explicitar as

\footnotetext{
${ }^{41}$ A obra "Adolescence: Its psychology and its relations to physiology, anthropology, sociology, sex, crime, religion and education", de Granville Stanley Hall (1904), marca os primeiros estudos acadêmicos sobre o tema da adolescência.
} 
considerações sobre a etapa do ensino médio no Brasil, com o intuito de compreender a formação de conceitos que, como vemos, corresponde a uma fração da realidade (sala de aula), inserida numa totalidade (Escola e Sistema de ensino).

Konder (2008, p. 35) assevera que, "se não enxergarmos o todo, podemos atribuir um valor exagerado a uma verdade limitada (transformando-a em uma mentira) prejudicando a nossa compreensão de uma verdade mais geral". Para a dialética marxista, o conhecimento é totalidade, e a atividade humana é uma atividade de totalização.

Este capítulo está dividido em dois tópicos: a etapa da adolescência e a história do ensino médio no Brasil.

\section{1 \\ O desenvolvimento humano e o período cognominado adolescência}

A ideia de desenvolvimento humano assumida neste texto é de que o gênero humano contemporâneo não é produto direto de sua herança biológica. É uma amálgama das atividades em diversos planos, que incluem o genético, o filogenético, o sociogenético e o microgenético (VIGOTSKI, 2001). Esses quatro planos agem em conjunto, viabilizando a existência de um sujeito que é, ao mesmo tempo, biológico e social. O desenvolvimento do psiquismo humano foi possível através da atividade de transformação do mundo. Ao executar as ações de transformação da natureza, de forma coletiva, para satisfazer as suas necessidades, ele também se modificou. O que foi produzido através desse processo foi transferido às gerações posteriores, por meio das relações histórico-sociais. Leontiev (1983) fundamenta o nosso argumento:

$\mathrm{Na}$ vida, cada geração começa em um mundo de objetos e fenômenos criados pelas gerações anteriores. Ele assimila essas riquezas com sua participação através do trabalho, na produção e nas várias formas de atividade social, que se cristalizou, que se encarnou neste mundo. Até a capacidade de usar uma linguagem articulada apenas na sua forma, para os representantes de cada geração, se dá através da assimilação de uma linguagem historicamente formada e de acordo com suas particularidades objetivas. $\mathrm{O}$ mesmo se aplica ao desenvolvimento do pensamento e à aquisição de conhecimento. (LEONTIEV, 1983, p. 225, tradução nossa) 
O autor destaca o papel da atividade e da cultura na construção do psiquismo humano. Retomaremos a discussão sobre o papel da atividade na construção do psiquismo no capítulo quatro. Ele também frisa o papel da assimilação da cultura através das relações sociais, o que possibilita a produção histórica social das funções especificamente humanas como o pensamento, a construção de conhecimento e a consequente formação dos conceitos. As funções psicológicas especificamente humanas, como o pensamento, a linguagem, a memória mediada, a emoção, os conceitos, etc., são formadas a partir das relações estabelecidas com outros seres humanos, mediadas pela cultura. Salientamos o papel do desenvolvimento dos conceitos como elemento essencial na construção de significados sobre o mundo, sobre os outros e sobre o próprio sujeito.

Detemo-nos na formação de conceitos porque entendemos ser primordial na construção do psiquismo dos seres mais desenvolvidos da nossa espécie. A formação dos conceitos é um processo complexo, que atravessa diferentes etapas do desenvolvimento que, mesmo não sendo rigidamente dispostas no tempo, têm o seu auge na fase conhecida como adolescência. Para Vigotski (2001, p. 350), com o desenvolvimento dos conceitos verdadeiros, o adolescente passa a ter uma maior possibilidade de adentrar no mundo complexo da abstração intelectual. Através deles, e com eles, o sujeito é capaz de dirigir melhor a sua conduta, além de passar a conceitualizar a realidade em termos abstratos.

Assim, o que ocorre é que "o novo uso significativo da palavra, seu uso como meio de formação dos conceitos, constitui a causa psicológica imediata da mudança radical que ocorre na atividade intelectual, que tem lugar na transição entre a infância e a adolescência" (VIGOTSKI, 2001, p. 74, tradução nossa) Um dos maiores ganhos da adolescência é que o sujeito passa a operar com conceitos verdadeiros e, com a sua conscientização, aumenta a capacidade de constituição de uma visão de mundo. $\mathrm{O}$ autor concebe a existência de duas categorias de conceitos: os conceitos espontâneos e os conceitos verdadeiros ou científicos.

Os conhecimentos espontâneos são aqueles que existem no sistema de aprendizagem da criança, antes da sua entrada na escola, e são provenientes da vida cotidiana e dos conhecimentos científicos adquiridos, sobretudo por meio da instrução, na escola. A diferença principal é que os conceitos espontâneos se formam a partir de uma relação imediata do sujeito com o mundo concreto, enquanto que, nos conceitos verdadeiros, a relação é inversa. O caminho se dá do 
abstrato para o concreto. $\mathrm{O}$ autor ressalta que é na adolescência que os conceitos verdadeiros são formados. Conforme atesta Talízina (2000, p. 219, tradução nossa) a divisão dos conceitos em científicos e não científicos ou cotidianos foi introduzido na psicologia por L. S. Vigotski. Para o autor, a diferença entre conceitos científicos e cotidianos não está relacionada apenas ao seu conteúdo, mas às formas ou vias de assimilação e por apresentar uma rica sequencia de enlaces e relações.

As vias de assimilação dos conceitos cotidianos são assistemáticas, limitando-se a relacionar o objeto com o seu conceito, por ensaio e erro, ou através da evidência de características não essenciais do objeto ou coisa. $\mathrm{Ou}$ ainda, mesmo que exibidas as características essenciais, elas ficam em nível não consciente. Ainda segundo Talízina, no caso dos conceitos científicos, a sua apresentação se dá de forma organizada e dirigida a um objetivo e a assimilação se inicia com a compreensão consciente de suas características, o que é alcançado com a introdução de sua definição (TALÍZINA, 2000, p. 220, tradução nossa) Sendo assim, a formação de conceitos verdadeiros exige certo nível de desenvolvimento das funções psicológicas complexas.

Acreditamos ser oportuno aprofundar na compreensão do processo de desenvolvimento humano, a fim de entender como se dá o processo de formação de conceitos científicos, uma vez que estão inter-relacionados. Esses conceitos são formados a partir de atividade organizada e orientada a um fim, que é a atividade de ensino. Para Vigotski (2001, p. 333), "o ensino deve fazer o desenvolvimento avançar" e a "aprendizagem e o desenvolvimento não coincidem imediatamente, mas que são dois processos que estão em constante inter-relação". O autor afirma que "a aprendizagem só é boa quando está à frente do desenvolvimento".

$\mathrm{O}$ autor fala da existência de duas áreas/zonas de desenvolvimento. A Zona de Desenvolvimento Real é a área em que o sujeito consegue resolver sozinho um determinado problema ou dificuldade e a Zona de Desenvolvimento Iminente $^{42}$, a área em que o sujeito resolve determinada situação somente com a ajuda de outro sujeito mais desenvolvido. Nas palavras do próprio Vigotski (2001,

42 Nas primeiras traduções das obras de Vigotski, os textos trazem os termos Zona de Desenvolvimento Potencial ou Proximal. Para Prestes (2010), a melhor tradução seria Zona de Desenvolvimento Iminente - ZDI, que revela aquilo que o sujeito pode realizar em colaboração com o outro mais desenvolvido ou, mais precisamente, as novas formações (neoformações) que estão em vias de florescer. 
p. 327), são "os processos que, no curso do desenvolvimento das mesmas funções, ainda não estão amadurecidos, mas já se encontram a caminho, já começam a brotar; amanhã, trarão frutos; amanhã, passarão para o nível de desenvolvimento atual". Segundo o autor, "a aprendizagem motiva e desencadeia para a vida toda uma série de funções que se encontravam em fase de amadurecimento e se realiza na Zona de Desenvolvimento Iminente”. Segundo Alvarez \& Del Río (1990, p. 96 - tradução nossa), ${ }^{43}$ o processo de formação das funções psicológicas superiores se dá através da atividade prática e instrumental, de forma cooperativa e não individual. O processo é o que denominamos como educação, que se dá na Zona de Desenvolvimento Iminente. Com esse procedimento, a espécie humana alcançou e modificou qualitativamente as leis biológicas da evolução.

Vigotski explica que é na Zona de Desenvolvimento Iminente que o professor deve atuar a fim de promover o desenvolvimento, ou seja, é o ensino que o produz. Essa é a situação fulcral da ideia de desenvolvimento da psicologia histórico-cultural. Aproveitamos para levantar algumas questões orientadoras, que serão respondidas ao longo deste capítulo. O que é desenvolvimento humano? Qual o papel da instrução formal no desenvolvimento humano? O que é adolescência? Quais atividades caracterizam a adolescência? Como a escola pode promover o desenvolvimento humano?

Para responder as essas questões, recorremos a Martins (2013), que define que os elementos conteúdo-forma-destinatário são diretamente ligados à prática pedagógica. Para a autora, tais elementos estão relacionados a uma prática pedagógica voltada à promoção do desenvolvimento. A tríade forma uma unidade indissociável, que deve orientar o trabalho pedagógico.

Muito embora tratemos separadamente cada um dos seus componentes, entendemos que esses elementos estão inter-relacionados; como são interdependentes, não podemos desconsiderá-los. O conteúdo trata do que será ensinado; a forma trata de como será o ensino; e o destinatário, de quem o recebe. Nosso interesse, aqui, é tratar especificamente dos destinatários, no caso a adolescência e os adolescentes, sem deixar de lado a forma e o conteúdo do ensino.

\footnotetext{
${ }^{43}$ Conferir o Vol. 2, 1990 (II. Psicología de la educación), ISBN 84-206-6531-2, p. 93-119.
} 
Em relação ao conteúdo, recorremos a Saviani (2013, p. 13), que entende que não é a natureza a responsável direta pela produção da essência humana, mas é determinada sócia e historicamente pelas relações com outros seres humanos; a educação tem um papel fundamental no processo de humanização. Segundo o autor, "o objeto da educação diz respeito, de um lado, à identificação dos elementos culturais que precisam ser assimilados pelos indivíduos da espécie humana, para que eles se tornem humanos, e, de outro lado e concomitantemente, à descoberta das formas mais adequadas para atingir esse objetivo". Nesse caso, temos a associação entre conteúdo e forma.

Enfatizamos a importância da assimilação de um conteúdo (saber), que demanda a historicidade. Sistematizado, contribui para instrumentalizar os destinatários, a fim de que conheçam, tanto quanto for possível, a realidade. Saviani (idem) ressalta que "o trabalho educativo é o ato de produzir, direta e intencionalmente, em cada indivíduo singular, a humanidade que é produzida histórica e coletivamente pelo conjunto dos homens". Para Asbahr (2011, p. 70), é função da escola "promover o desenvolvimento dos estudantes, especialmente no que diz respeito à formação do pensamento conceitual".

A autora destaca a relação entre o ensino escolar e o desenvolvimento, considerando o primeiro responsável pelo segundo. Afirma que, se o que for ensinado estiver na área em que o sujeito já sabe realizar ou resolver por conta própria, não se produz desenvolvimento. Vemos o quanto a autora vincula a aprendizagem ao desenvolvimento. Mas a afirmação suscita alguns questionamentos. Qualquer aprendizagem produz o desenvolvimento? Qual seria o conteúdo ou o currículo adequado?

Ainda sobre os conteúdos ou a sua sistematização, recorremos de novo a Saviani (2013, p. 13), para ele, trata-se de distinguir entre o que é essencial e o acidental, o principal e o secundário, o fundamental e o acessório. $\mathrm{O}$ autor destaca também a necessidade de que os estudantes, principalmente os das classes mais populares, tenham acesso aos conhecimentos que ele chamou de clássicos ${ }^{44}$. $\mathrm{O}$ critério, segundo ele, seriam aqueles conteúdos que se firmaram como fundamentais e essenciais, historicamente. Defende que é função da escola

\footnotetext{
${ }^{44}$ Segundo Saviani (2013, p. 13), o clássico não se confunde com o tradicional e também não se opõe, necessariamente, ao moderno e muito menos ao atual. O clássico é aquilo que se firmou como fundamental, como essencial.
} 
apresentar aos estudantes o conhecimento elaborado, sistematizado, ou seja, o conhecimento científico. Leiamos um fragmento literal do autor sobre o papel da escola e dos conteúdos escolares:

A escola existe, pois para propiciar a aquisição dos instrumentos que possibilitam o acesso ao saber elaborado (ciência), bem como o próprio acesso aos rudimentos desse saber. As atividades da escola básica devem organizar-se a partir dessa questão. Se chamarmos isso de currículo, poderemos então afirmar que é a partir do saber sistematizado que se estrutura o currículo da escola elementar. (Saviani, 2013, p. 14)

Ou seja, a escola desempenha o papel de ser o lócus mais específico para a difusão do conhecimento científico. O currículo, por conseguinte, é formado pela sistematização desses conhecimentos curriculares. Assim a existência da escola está profundamente relacionada à transferência do conhecimento elaborado às novas gerações. Essa preocupação do autor com a organização dos conteúdos favorece a relação entre a pedagogia e a psicologia e, dessa maneira, o encontro com a psicologia histórico-cultural. Para Davidov (in Shuare, 1987, p. 150, tradução nossa) "todo ensino deverá conservar a vinculação e sucessão dos conhecimentos, mas deverá tratar de um enlace entre estágios qualitativamente diferentes tanto pelo conteúdo, quanto pelos procedimentos utilizados”.

No que diz respeito à forma, Saviani (2013, p. 13) fala da "organização dos meios (conteúdos, espaços, tempo e procedimentos) através dos quais, progressivamente, cada indivíduo singular realize, na forma de sua segunda natureza, a humanidade produzida historicamente". Martins (2017, p. 19) entende que o desenvolvimento do pensamento requer o estabelecimento de mediações cada vez mais abstratas entre as impressões concretas advindas da captação sensível da realidade. Segundo a autora", a "forma organizativa pelos quais a aprendizagem ocorre, não são fatores que possam ser secundarizados", e "há que se identificar no ato educativo sob quais condições a aprendizagem opera, deveras, a serviço do desenvolvimento dos indivíduos".

O terceiro elemento da tríade são os destinatários. Nosso entendimento é de que, para que o ensino seja promotor do desenvolvimento, é indispensável conhecer, da forma mais aprofundada quanto possível, os destinatários do

\footnotetext{
${ }^{45}$ ibid, p, 21.
} 
processo educativo. Trata-se de conhecer os aspectos psicológicos, sociais e biológicos relativos a cada período de desenvolvimento humano, no nosso caso específico, a adolescência. Conforme já vimos, a adolescência é um período qualitativamente diferente dos períodos que a antecedem. Uma das diferenças fundamentais caracteriza-se pela formação dos conceitos verdadeiros. Já nos referimos ao papel dos conceitos verdadeiros, especificamente dos conceitos científicos, e o papel do processo ensino-aprendizagem.

No tocante à efetividade do processo ensino-aprendizagem, é imprescindível que se conheçam os destinatários. O período da adolescência teve, para Vigotski, um significado especial. Ele produziu um texto específico sobre o assunto, que aparece nas Obras Completas IV, com o título "O desenvolvimento do pensamento do adolescente e a formação de conceitos". No texto, o autor se refere mais nomeadamente à adolescência e a relaciona especificamente à formação de conceitos.

O processo de desenvolvimento humano, conforme já explicitamos, possui condicionantes sócio-históricos, embora se dê sobre uma base biológica. Em nosso entendimento, os aspectos psicológicos e biológicos estão intrinsicamente combinados no processo de desenvolvimento, formando uma unidade. Para a psicologia histórico-cultural, a adolescência não pode ser reduzida a apenas um processo de mudanças biológicas, naturais, caracterizadas em virtude do desenvolvimento hormonal.

Conforme Duarte e Anjos (2017, 125), a adolescência é entendida a partir de duas vertentes: uma psicopatológica e a outra essencialmente biológica. Nas palavras dos autores, "a adolescência não pode ser vista apenas como um momento de crises emocionais, comportamentos semipatológicos, por vezes inconscientes, devido aos hormônios que estão à flor da pele". Completam a declaração explicando que, "a gênese do comportamento adolescente não está, portanto, nas manifestações metapsicológicas, tampouco pode ser reduzida à maturação cerebral como afirmam as concepções biologizantes”. É evidente que não se pode negar ou negligenciar os aspectos biológicos do desenvolvimento, mas eles devem ser vistos, antes de tudo, como um fenômeno essencialmente cultural. As manifestações de ordem cerebral e fisiológica são influenciadas diretamente pela assimilação da cultura. 
O desenvolvimento psíquico, na adolescência, está atrelado diretamente à cultura, sendo essas assimilações as responsáveis diretas pelas neoformações que ocorrem nessa etapa. $\mathrm{O}$ ensino e a formação de conceitos exercem uma marcante função no processo de desenvolvimento do adolescente. Ao operar com conceitos, os adolescentes constroem conhecimentos e habilidades que lhes permitem conceber o mundo e construir a sua autoconsciência por meio das funções psicológicas superiores.

Para Vigotski, não é qualquer ensino que promove o desenvolvimento. O chamado 'bom ensino' é aquele que se adianta ao desenvolvimento:

Vigotski demonstra que o bom ensino é aquele que está à frente do desenvolvimento, aquele que não está orientado para os ciclos acabados, mas para aqueles que acabaram de aparecer. A educação, de acordo com Vigotsky, tem um significado progenerativo para o processo de desenvolvimento. (VIGOTSKI, Obras escogidas, Tomo IV, p. 11, tradução nossa $)^{46}$

Fica claro que o autor entende que o desenvolvimento psíquico é dependente da aprendizagem. Em sua visão, a educação tem um caráter progenerativo, ou seja, tem anterioridade em relação ao desenvolvimento. Em outras palavras, a aprendizagem é responsável diretamente por promover o desenvolvimento.

Ainda sobre o ensino desenvolvente ${ }^{47}$, Martins (2013) pontua que, para que ensino escolar aja como uma influência positiva na formação e no desenvolvimento das funções psicológicas superiores, como a memória voluntária, por exemplo, há que se considerar, fundamentalmente, a sua organização e sistematização lógica, a promoção do estabelecimento de relações e conexões internas entre os objetos percebidos, mediando a percepção dos conceitos lógicos e abstratos, sobretudo pelo domínio de significados e vínculos. A própria organização racional do trabalho pedagógico se apresenta como base para o desenvolvimento psíquico superior. Dessa maneira, a utilização de recursos externos, de técnicas apropriadas (instrumentais) e a combinação de diversos

\footnotetext{
46 Cf. Obras escogidas. Tomo IV. Disponível em: <https://edisciplinas.usp.br/pluginfile.php/289941/mod_folder/content/0/Tomo\%204\%20.pdf?forc edownload=1> Acesso em: 15 de maio 2016

${ }^{47}$ A ideia de ensino desenvolvente se refere a abordagem educativa de Elkonin-Davydov, que estudaram especificamente a estrutura, conteúdo e gênese da atividade de estudo que são capazes de promover o desenvolvimento.
} 
procedimentos didáticos resultariam, pouco a pouco, na internalização dos signos e na construção de sentidos pelos estudantes.

Valemo-nos de Elkonin (1987, 118-119, tradução nossa) para quem "a atividade de estudo mediatiza todo o sistema de relações" das crianças com os adultos. De acordo com o autor, há uma atividade principal $^{48}$ em cada período do desenvolvimento. Essas atividades são de origem social e se tornam predominantes em determinada fase - ele as chama também de "atividades reitoras", que são as causas do desenvolvimento naquele período. O autor reconhece que há uma dificuldade em determinar a atividade principal pelo próprio adolescente, devido ao fato de que ela parece continuar sendo a mesma da infância, que é o estudo. Para ele, os êxitos e os fracassos durante a aprendizagem escolar continuam sendo os critérios fundamentais que os adultos utilizam para avaliar os adolescentes.

O processo de 'amadurecimento', então, não se dá de forma tranquila, pois está condicionado à organização da própria sociedade. Ele exerce influência na formação da personalidade do adolescente, assim como as mudanças físicas e intelectuais. No entanto, a mais importante mudança está na capacidade de formação dos conceitos, o que propicia não somente perceber melhor o mundo, mas também atuar sobre ele, compreender melhor as suas emoções e as suas relações com a potencialização de sua consciência e autoconsciência.

As atividades principais, nesse período, são o estudo e a comunicação íntima pessoal. Elkonin (1987), em suas investigações, percebeu que nesse período há a subordinação das relações estabelecidas com outros adolescentes, através do que chamou de um "código de companheirismo". Isso explica a observação que se faz de que os adolescentes, na fase inicial, preferem estar em grupos. Essa esfera da vida comum com o companheiro ocupa, no período da adolescência, um espaço importante e, com isso, se estrutura o sentido pessoal da vida e se forma a autoconsciência como "consciência trasladada do interior". Segundo Leontiev, o sentido é criado pela relação com aquilo que provoca a ação (motivo da atividade) e o fim da ação. O sentido pessoal da escola é aquele que ela tem para a sociedade. Leontiev pondera sobre a ideia de comunicação íntima pessoal da fase:

\footnotetext{
${ }^{48}$ Nos textos em espanhol, foi traduzida como actividad rectora. Nos textos em português, vemos a tradução "Atividade-guia". Nesta tese, optamos por usar "Atividade principal".
} 
Esta entrada do adolescente em um círculo mais amplo de comunicação não significa, no entanto, que o íntimo, o pessoal, passa agora para um tipo de fundo. Pelo contrário, precisamente neste período e precisamente por essa razão, ocorre um desenvolvimento intensivo na sua vida íntima, junto com a companhia vem a amizade, que se alimenta de confidências mútuas; trocas de mensagens, que perdem seu caráter estereotipado e descritivo, manifestando neles as experiências; se planeja a manter um diário íntimo e, inicia as primeiras paixões. (1983, p. 174, tradução nossa)

O autor manifesta o seu entendimento de que o chamado "mundo interior" é construído a partir das exigências sociais e, principalmente, das relações estabelecidas com indivíduos do círculo de amizades dos adolescentes. Através dessas relações, sobrevém uma nova reestruturação dos motivos da atividade, que estimula o indivíduo e tem expressivas consequências sobre o desenvolvimento de sua personalidade.

A escola adquire um papel importante na organização dos motivos da atividade, que nos mantêm dispostos para a ação. Na sociedade de classes como a nossa, a personalidade se desenvolve de forma alienada e parcializada, pois o sentido da atividade, que é pessoal, está afastado do significado, que é social. Para o autor, a personalidade se desenvolve por meio das condições concretas e históricas de vida e o pertencimento do sujeito a determinada classe condiciona, desde o início, o desenvolvimento de seus vínculos com o mundo circundante, a maior ou menor amplitude de sua atividade prática, de suas comunicações, de seus conhecimentos e das normas de conduta que assimila. Ainda sobre o desenvolvimento da personalidade, o autor destaca que a "primeira base da personalidade, que não pode ser ignorada por nenhuma concepção psicológica é a riqueza de vínculos do indivíduo com o mundo" (LEONTIEV, 1983 p. 178, tradução nossa).

Conforme Elkonin (in Shuare, 1987, p. 120, tradução nossa), essta fase de desenvolvimento é consistente com o estabelecimento de relações com outros companheiros sobre uma base de certas normas éticas e morais, que acabam por mediatizar os seus atos. $\mathrm{O}$ autor explicita que esse processo se dá sobre uma base de completa confiança e partilha da vida interna. A comunicação pessoal constitui a atividade na qual são constituídos os pontos de vista gerais sobre a vida, sobre as 
relações entre pessoas, o futuro próprio; é nesse momento que se estrutura o sentido pessoal da vida ou o plano de vida.

Assim, surgem as premissas para que se originem novas tarefas e motivos relacionados à atividade conjunta, que se converte em atividade dirigida ao futuro e adquire o caráter de atividade profissional de estudo. Em conclusão, consideramos, nesta tese, que a adolescência tem como atividades principais a comunicação íntima pessoal e a atividade profissional de estudo. Essas atividades não são provenientes da organização histórica social e acabam por organizar o universo que entendemos como adolescência e os próprios sujeitos que vivem e convivem nesse período.

Destarte, podemos relacionar a formação de conceitos ao desenvolvimento da capacidade de comunicação íntima pessoal e a escolarização como atividade promotora do desenvolvimento. Levantamos as seguintes questões: De qual escola estamos falando? Como ela funciona? A escola e o ensino que temos no Brasil são capazes de promover o desenvolvimento multilateral ou integral do ser humano? No próximo tópico, trataremos brevemente da história dessa modalidade de ensino no Brasil e tentaremos trazer respostas, mesmo que provisórias, a essas questões.

\section{2}

\section{Teoria histórico-cultural e a trajetória da formação de conceitos}

Nesta seção, expomos brevemente sobre Lev Semionovich Vigotski (1896-1934), importante intelectual Bielorusso, de origem judaica, que trouxe significativas contribuições a diversas áreas do conhecimento, como a pedagogia, a psicologia e a neuropsicologia. Seus principais trabalhos foram produzidos em um período relativamente curto de sua vida, aproximadamente dez anos. Morreu precocemente, possivelmente de tuberculose ${ }^{49}$, doença muito comum na sua época.

A presença desta seção justifica-se pelo fato de que Vigotski, juntamente com seus continuadores, viveram em um período profundamente conturbado da história moderna. Constatamos uma intensa e profunda relação dialética entre as

\footnotetext{
${ }^{49}$ Para Prestes e Tunes (2018, p. 9), se "L. S. Vigotski não tivesse falecido de tuberculose na madrugada de 11 de junho de 1934, seria, sem dúvida, mais um nome da enorme lista de mortos pelas mãos de Stalin no grande expurgo que ocorreu nos últimos anos da década de 1930 [...]”.
} 
suas vivências e as suas produções científicas. O pioneirismo de Vigotski se deve à edificação de uma psicologia fundamentada nos princípios do materialismo histórico-dialético ${ }^{50}$ de Karl Marx e Friedrich Engels.

Os principiais fundamentos de Vigotski, em sua teoria sobre o psiquismo humano, podem ser assim sistematizados: o primeiro é o da sua gênese cultural; o segundo é o caráter materialista histórico do desenvolvimento humano; o terceiro consiste em compreender que o psiquismo humano é fundamentalmente diferente do psiquismo dos animais; e o quarto é que todas as funções psicológicas humanas aparecem duas vezes na vida de um indivíduo, primeiramente no nível interpsicológico ou intersubjetivo e depois no intrapsicológico ou intrasubjetivo (SHUARE, 2016, p. 25). Esse processo, chamado de internalização, foi amplamente estudado por P. Ya. Galperin e N. Talízina, posteriormente. O conceito será examinado no capítulo III, seção 4.6 desta tese.

Vigotski compreendeu que a base do psiquismo humano se encontra na sua ação direta sobre a natureza, de maneira a obter dela as condições materiais e concretas da sua existência. Esse foi o ponto de virada de uma existência governada pelas suas necessidades biológicas para o campo das necessidades culturais. Essa relação com os objetos levou à construção de instrumentos e, ao mesmo tempo, à produção dos signos. Foi um processo longo, que conduziu à edificação do psiquismo especificamente humano. É lícito supor que exista uma sociabilidade natural. No entanto, com o advento da vida social, o ser humano transcende do biológico para o histórico-social. Essa é a principal diferença entre o psiquismo humano e o animal.

Assim, a atividade humana sobre a natureza culminou com a produção dos instrumentos e signos, o que contribuiu para a complexificação do psiquismo. Ao interiorizar esses produtos da vida social, o ser humano transformou as funções elementares, de origem biológica, em funções complexas ou superiores. O desenvolvimento humano passou a tirar proveito da ordem social e histórica. É por esse motivo que Vigotski afirma que, "no desenvolvimento cultural da criança, toda função aparece duas vezes: primeiro a nível social e mais tarde a

\footnotetext{
${ }^{50}$ A referência explícita ao materialismo histórico-dialético como orientador das ideias de Vigotski aparece no texto conhecido como "Manuscrito de 1929". O texto foi publicado em Educação \& Sociedade, ano XXI, $\mathrm{n}^{\circ}$ 71, Julho/00 23. Disponível em: 〈http://www.scielo.br/pdf/es/v21n71/a02v2171.pdf〉
} 
nível individual; primeiro entre pessoas (interpsicológica), e depois no interior da própria criança (intrapsicológica)" ${ }^{\Perp 1}$.

Para Vigotski (2001, p. 149), "um desenvolvimento não é a simples continuação direta de outro, mas ocorre uma mudança do próprio tipo de desenvolvimento - do biológico para o histórico-social”. Dessa maneira, o psiquismo humano só poderia ser compreendido a partir do estudo de suas bases materiais e históricas. A sua gênese está na atividade do homem que, ao atuar sobre a natureza, transformando-a para atender às suas necessidades, transforma a si e aos outros.

O seguinte parágrafo elucida o papel desempenhado pelo método no estudo das funções psicológicas:

[...] devemos esperar de antemão que, em linhas gerais, o próprio tipo de desenvolvimento histórico do comportamento venha a estar na dependência direta das leis gerais do desenvolvimento histórico da sociedade humana. Com isso, o próprio problema do pensamento e da linguagem ultrapassa os limites metodológicos das ciências naturais e se transforma em questão central da psicologia histórica do homem, ou seja, da psicologia social; ao mesmo tempo, modifica-se a própria abordagem metodológica do problema. Sem tocar na questão em toda a sua plenitude, achamos necessário analisar os seus pontos fulcrais, aqueles mais difíceis em termos metodológicos, porém mais centrais e mais importantes para uma análise do comportamento do homem baseada no materialismo dialético e histórico. (VIGOTSKI, 2001, p. 149-150)

O autor elege o materialismo dialético e histórico como a via a ser trilhada para a compreensão dos fenômenos tipicamente humanos, como, no exemplo, o pensamento e a linguagem. Ele não descarta o método das ciências naturais, mas constata a sua limitação; defende que as funções da linguagem e do pensamento são de ordem biológico-cultural. Entendemos que esta seja a matriz que fundamenta a teoria de Vigotski.

Nas palavras de Shuare (2016, p. 80), “a luta que Vigotski assumiu em várias frentes, fundamentada em sua ampla e profunda cultura filosófica e, em particular, de um domínio criativo e surpreendente do marxismo [...]”, permitiulhe estabelecer uma proposta diferente daquelas que havia nas diversas psicologias de sua época, procurando se distanciar das que entendiam a origem do

${ }^{51}$ In: VYGOTSKI, L.S. Obras Escogidas. Vol. III, p. 149, Moscou: Ed. Progreso, 2012. 
psiquismo por uma base científico-natural, ou então pela determinação social direta, na busca cientificista positivista, ou ainda das que se baseavam em citações dos clássicos do marxismo. Para ele, faltava à psicologia escrever o seu 'capital', por isso indicou que as bases dessa proposta estavam na teoria materialista histórico-dialética.

Mas, para a compreensão das ideias de um intelectual do porte de Vigotski, é necessário nos remetermos à sua época e à sua história, pois, conforme ele mesmo dizia, os homens são produtos das vivências e das condições históricas de seu tempo. Muito embora Vigotski tenha tido um tempo relativamente curto de vida, a sua produção científica contribuiu sobremaneira para a psicologia soviética. Mesmo tendo sido censurada no período stalinista, foi restaurada e hoje é reconhecida como uma relevante teoria.

O jovem Vigotski vivenciou pelo menos três grandes revoluções na antiga Rússia do início do século XX. A primeira, no período de 1904-1905, foi a guerra travada contra o Japão; a segunda foi a primeira tentativa de revolução de 1905, ainda na Rússia czarista. Esses eventos foram o prenúncio daquilo que viria ocorrer em 1917, que foi a grande revolução socialista, capitaneada pelo partido Bolchevique $^{52}$. Segundo Hobsbawm (2002, p. 410), o fracasso dos russos na guerra contra o Japão foi um importante componente na derrocada do regime Czarista. Nas palavras do autor: "a guerra russo-japonesa de 1904-1905, embora tenha matado 84 mil japoneses e ferido 143 mil, foi um rápido e humilhante desastre para a Rússia, ressaltando no enfraquecimento do czarismo".

Analisa o historiador "o maciço avanço eleitoral dos partidos socialistas e operários era agora auxiliado pela difusão do sufrágio democratizado, que the permitia ser eficazmente registrado" e as "ondas de agitação operária produziam um avanço ainda maior na força do sindicalismo organizado" (HOBSBAWN, 2002, p. 119). Assim, no início do século XX, o mundo ocidental vivia uma mudança significativa em seu sistema político, com um extraordinário aumento da participação popular nas eleições. Os movimentos socialistas e operários eram os maiores defensores da participação popular nas decisões dos governos.

\footnotetext{
52 Segundo Reed (2016), os bolcheviques (bolshinstvo - “membros da maioria”), constituíam o partido político que, em 1917, era autointitulado de Partido Comunista. Os bolcheviques pregavam a insurreição proletária e a tomada das rédeas do governo, a fim de acelerar o advento do socialismo por meio da conquista, à força, da indústria, das terras, dos recursos naturais e das instituições financeiras.
} 
Esses eventos e muitos outros vivenciados por Vigotski provocaram a queda do império dos czares e a instalação de um 'parlamento', a chamada Duma $^{53}$, com a finalidade de acalmar os ânimos dos revoltosos. A eleição para a composição desse parlamento ocorreu de forma indireta e a participação da alta burguesia era evidente, o que produziu grandes descontentamentos. Essa torrente de mudanças do início do século XX, especialmente na Rússia, culminou com a constituição das Repúblicas Socialistas Soviéticas - URSS.

Foi nesse período, marcado por efervescências políticas e econômicas na Rússia, que viveu o jovem L. S. Vigotski. No início de sua vida, o seu foco estava principalmente na arte, passando depois pela educação, pela psicologia e até pela neuropsicologia. Com o advento da revolução, Vigotski e seu grupo estavam mergulhados nos estudos sobre o desenvolvimento humano, como forma de contribuir para resolver os graves problemas educacionais da nova sociedade e, assim, colaborar com a revolução. Conforme já apontamos, ele não trabalhou sozinho na edificação do que chamou de 'nova psicologia' ou psicologia geral. Ele contou com o trabalho de outros dois importantes estudiosos, A. R. Luria e A. N. Leontiev. O grupo ficou conhecido como a troika ${ }^{54}$.

Há um litígio na biografia de Vigotski, em relação à existência efetiva da troika. Guita Vigodskaia, a única filha de Vigotski, não tem dúvida de que o grupo liderado por seu pai era muito unido e que seus membros compartilhavam dos mesmos ideais. Em entrevista concedida a Prestes (2010, p. 254), foi indagada sobre a existência da Troika: "Algumas fontes estrangeiras dizem que não existiu a troika - Luria, Vigotski e Leontiev. A senhora acha que ela não existiu?’. Sua resposta foi contundente: "como não houve... sobre isso nem Luria e até mesmo Leontiev não negava isso, só mais no final. Existiu sim a troika, e eles se encontravam na nossa casa!".

Segundo ela, ainda na mesma entrevista, o grupo cresceu porque se juntaram mais cinco proeminentes estudantes e pesquisadores, formando a vosmiorka $^{55}$ : Alexander Vladimirovich Zaporozhets (1905-1981), Levina Rosa Ievguenievna [?], Lidia Ilinichna Bozhóvich (1905-1981) e Slavian Leia

\footnotetext{
${ }^{53}$ A duma, segundo John Reed significa, aproximadamente, "corpo deliberativo" uma espécie de parlamento. A velha Duma Imperial, instituída em 1905, como finalidade de acalmar os ânimos, ainda subsistiu até setembro de 1917.

54 "Troika" em russo significa um comitê formado por três membros ou um carro conduzido por três cavalos alinhados lado a lado, ou mais frequentemente, um trenó puxado por cavalos.

55 "Vosmiorka" significa octeto, em russo.
} 
Salomonovna [?]. Trazemos aqui um trecho da entrevista de Guita, concedida a

Prestes, que ilustra o ponto de vista assumido:

E quando juntos começaram a pensar e desenvolver, a partir de 1927, a teoria histórico-cultural, então cada um desses membros, até mesmo os estudantes, recebeu a sua tarefa concreta. Ocupavam-se de pictogramas, cada um desenvolvia seu eixo e, nas reuniões da vosmiorka, cada um apresentava o seu relatório, discutia-se o que cada um conseguiu obter e se planejavam os próximos passos. A troika existiu sim, eu garanto. (Prestes, 2010, p. 1027)

Mesmo com o aumento do grupo, com a agregação de estudantes, a troika possivelmente foi o ponto de união de todos. Com a distribuição das tarefas de pesquisa, o grupo passou a produzir muitos e novos conhecimentos, por muito tempo. Ainda segundo Prestes (2010, p. 255), a filha de Vigotski concluiu: "de fato, trabalharam praticamente juntos até a morte de Vigotski, que ocorreu em 1934. A troika existiu praticamente desde 1924 até 1934. E os dois [Leontiev e Luria] estiveram no enterro de Vigotski”. Assim, não é possível considerar que a chamada troika tenha sido um mito.

Continuando com a narrativa histórica, no ano de 1924, já no período da URSS, o jovem Vigotski, com 28 anos, escreveu um dos seus mais impressionantes textos, intitulado Psicologia pedagógica, que já trazia alguns dos princípios que seriam desenvolvidos posteriormente e comporiam a estrutura teórica. Prestes elucida que (2010, p. 47) "nesse livro refletem os desafios com os quais a educação pós-revolução socialista vinha se deparando na URSS: a formação do homem novo e de uma escola nova". O texto citado, Psicologia pedagógica, está inteiramente ligado à atividade prática pedagógica. Segundo a autora, "já pode ser observada a abordagem dialética sobre o desenvolvimento" e o "papel do ambiente social".

Vigotski produziu intensamente: cerca de $270^{56}$ trabalhos, num período de dez anos. Destacamos outros dois textos que em nosso entendimento, revolucionaram o pensamento psicológico: "El problema del desarrollo de las

\footnotetext{
${ }^{56}$ Na biografia de L. S. Vigotski, escrito por Vigodskaia \& Lifanova (1996) aparecem 274 trabalhos.
} 
funciones psíquicas superiores" (1931/1995) e "Pensamento e linguagem 57," ou "A construção do pensamento e da linguagem” (1934/2001), o último texto escrito pelo autor.

Em relação ao primeiro texto, o autor discute o problema, o método, a estrutura e a gênese das funções psicológicas superiores. Vigotski estudou os processos de constituição das funções psicológicas essencialmente humanas, que "são produtos do desenvolvimento histórico da humanidade e que também traz na sua ontogênese a sua história peculiar" $" 58$.

No prólogo do último texto, o autor discorre sobre as pesquisas realizadas no campo da linguística e do pensamento necessárias para a sua composição (VIGOTSKI, 2001, p. 16). Segundo ele, foi o resultado de um longo período de investigações: "o estudo do pensamento e da linguagem abrange inevitavelmente, uma série de campos mistos e contíguos do conhecimento científico" (XXXX). Ainda: "a comparação dos dados da psicologia da linguagem e da linguística, do estudo experimental dos conceitos e da teoria psicológica da educação foi inevitável neste processo".

No final do prólogo, afirma que "o tema do pensamento e da linguagem é questão fulcral de toda a psicologia do homem". No mesmo texto, apresenta os estudos sobre o processo de formação de conceitos, tema que será tratado com maior profundidade na próxima seção 4.

$\mathrm{Na}$ era do stalinismo, os textos escritos por Vigotski, foram considerados perturbadores e proscritos, sendo banidos por cerca de 20 anos, de 1936 até 1956. Mesmo assim, nesse período, os seus discípulos continuaram a desenvolver estudos baseados em suas ideias.

Conforme explicitado, o objetivo desta seção foi apresentar brevemente o contexto histórico da psicologia de Vigotski e expor sobre o movimento de criação de suas ideias. Vigotski, como qualquer outro autor, é produto do seu tempo.

\footnotetext{
${ }^{57}$ No Brasil foi publicado um livro de A. R. Luria com o título "Pensamento e linguagem: as últimas conferências de Luria". Trata-se de uma obra do próprio Luria. Entretanto, o título causa certa confusão.

${ }^{58}$ Obras Escogidas - Tomo IV - [?], tradução nossa.
} 


\subsection{1 A trajetória que leva à formação dos conceitos}

Vigotski (2001, p. 174) constatou que o processo que culmina com o desenvolvimento dos conceitos é complexo, com avanços e possíveis retrocessos, consequentemente, não é um processo linear. Em suas pesquisas, Vigotski e seus colaboradores definiram que o desenvolvimento de conceitos envolve três estágios: (1) o pensamento sincrético; (2) o pensamento por complexos; e (3) o pensamento conceitual.

Para Vigotski ${ }^{59}$, o estágio do pensamento sincrético é típico das crianças que se encontram no início da primeira infância, quando o pensamento se caracteriza pela formação de uma pluralidade não informada e ordenada de objetos. Esse amontoado de objetos do mundo, organizado de forma indiferenciada no seu pensamento, tem implicações sobre o sentido da palavra ou do signo. Nesse estágio, o significado da palavra é um encadeamento não discriminado de objetos e coisas, organizados em uma imagem combinada que não pode ser desmembrada.

Mesmo assim, com um vocabulário restrito de palavras, dotadas ainda de pouco significado, a criança pode produzir alguns laços objetivos entre os objetos, coincidindo sobre o significado das mesmas palavras estabelecidas na linguagem do adulto. Entretanto, os caminhos são diferentes, pois esses conceitos ainda estão atrelados aos contextos em que foram aprendidos. Mesmo onde os significados da criança parecem coincidir com os do adulto, eles são produtos da mistura sincrética de ideias, imagens e representações.

A transição do primeiro estágio para o segundo se dá a partir do momento em que as crianças já possuem algum significado básico das palavras. Esse estágio também conduz à formação de vínculos, ao estabelecimento de relações entre diferentes impressões reais, ao ordenamento e sistematização da experiência da criança. No entanto, os objetos não são agrupados por vínculos subjetivos que acabaram de surgir no pensamento da criança, mas por vínculos que agora são objetivos e que realmente existem nos objetos.

Vigotski (2001, p. 178) designou esse estágio longo e complexo como pensamento por complexos. Os objetos são agrupados segundo as estruturas

59 Ibid., p. 175. 
complexas dos objetos particulares. Nesse período, mais que a internalização de significados prontos, a criança está construindo o seu vocabulário de palavras. Ela já consegue unificar objetos homogêneos em um grupo comum e torná-los complexos utilizando vínculos objetivos que descobrem através dos próprios objetos. Para Vigotski, em vez do pensamento "nexo desconexo", quando há ligação e quando não há ligação entre as partes, que serviu ao pensamento sincrético, os agrupamentos que são feitos agora entre os objetos são baseados nas características peculiares que estão presentes, naquele momento, em seu campo perceptual.

O estágio de pensamento por complexo constitui um avanço no processo que conduz à formação dos conceitos científicos, no período da adolescência. As leis do pensamento por complexo são, ainda, completamente diferentes da lei dos conceitos. Vigotski ${ }^{60}$ explica que mesmo a linguagem dos adultos ainda mantém o que ele chama de resíduos do pensamento por complexos. O que distingue o pensamento por complexo do pensamento sincrético é o fato de que, neste último, a criança já consegue produzir um vínculo mais concreto e factual entre os objetos de um grupo e se baseia em sua experiência imediata.

O pensamento por complexo é a generalização ou a unificação de objetos heterogêneos concretos, mas o vínculo é variado e qualquer possibilidade pode levar a criança a incluir um determinado elemento no complexo. Para isso, basta que a criança constate que existe algum traço característico entre objetos. Esse processo é diferente daquele que ocorre com o conceito, que é a uniformidade dos vínculos entre os objetos. $\mathrm{O}$ conceito se caracteriza por sua generalidade. Todos os elementos de um grupo estão vinculados a uma totalidade expressa em um conceito, e, através desse conceito, estão ligados entre si, num vínculo do mesmo tipo.

Nos estudos do pensamento por complexo, há diversas fases, formando um sistema. Esse sistema de complexos fundamenta as generalizações que aparecem no pensamento da criança. Nas pesquisas realizadas por Vigotski e seus colaboradores, foram encontradas, pelo menos, cinco fases do pensamento por complexos: (1) complexo associativo; (2) complexo de coleções; (3) complexo em cadeia; (4) complexo difuso; (5) pseudoconceito.

${ }^{60}$ Ibid, p. 180. 
1) Complexo do tipo associativo: baseia-se em todo e qualquer nexo que a criança note entre os objetos. É um tipo de associação por semelhança, em que qualquer conexão entre o objeto do núcleo e outro já é suficiente para que a criança inclua esse objeto no grupo e o designe pelo "nome de família". A conexão não tem de ser necessariamente um traço comum - como cor ou forma -, uma semelhança ou regularidade no espaço - como estar perto ou longe, acima ou abaixo. Pode ser o critério usado pela criança para estabelecer a ligação. Para a criança que se encontra ainda na primeira infância, a palavra deixa de ser o nome próprio do objeto. Em outros termos, a palavra torna-se o nome de um grupo de objetos "família".

2) Complexo do tipo coleções: as crianças costumam combinar os objetos pelas impressões que causam nelas. Os objetos são combinados por qualquer traço que difiram, complementando-se mutuamente. Nas experiências de Vigotski (2001), as crianças tomavam objetos que diferiam da amostra pela cor, forma, tamanho, ou qualquer característica percebida. No caso das coleções, as escolhas dos objetos ou coisas, pelas crianças, são feitas por contraste com o atributo da amostra que tomaram como base do agrupamento.

O resultado é uma coleção das cores e formas presentes no material da experiência. Às vezes, a forma de pensar da criança se combina com a forma associativa, o que produz uma coleção baseada em princípios mistos. Outro aspecto relevante diz respeito à dificuldade encontrada em se manter fiel ao princípio que originalmente aceitara para base da seleção. Essa fase constitui uma das mais longas e persistentes do desenvolvimento infantil. Por exemplo, um copo, um prato ou uma colher podem ser um exemplo comum do complexo por coleções com que a criança convive no dia a dia.

3) Complexos do tipo cadeia: referem-se a uma junção dinâmica e com sequência isolada de determinado objeto, sendo o significado transmitido de um para outro. $\mathrm{O}$ atributo varia durante todo o processo. $\mathrm{O}$ tipo de nexo ou a forma como cada parte da cadeia se articula com os precedentes ou subsequentes não apresenta coerência, considerando que a amostra inicial não é relevante. Cada parte ou elo pode atrair mais uma série de objetos. Esse complexo pode ser 
considerado a forma pura do pensamento por meio de complexos, visto não ter um núcleo, estabelecendo-se relações entre elementos isolados, adquirindo, dessa forma, uma qualidade vaga e flutuante. O tipo e a natureza das ligações podem mudar de um elo para outro imperceptivelmente. Muitas vezes, uma semelhança remota é suficiente para criar uma ligação entre as partes da cadeia.

4) Complexo do tipo difuso: é marcado pela fluidez do atributo que une seus elementos individuais. Os complexos resultantes desse tipo de pensamento são tão indefinidos que podem não ter limites. A criança constrói surpreendentes complexos que se tornam ilimitados pela universalidade das ligações envolvidas. Percebe-se que, nesta fase, a criança ainda permanece nos limites dos vínculos concretos entre os objetos. Os vínculos que as crianças produzem entre os objetos muitas vezes se baseiam em traços incorretos, indefinidos e flutuantes. Isso ocorre, principalmente, quando os objetos estão fora dos conceitos cotidianos da criança.

5) Complexo de pseudoconceito: Neste tipo de complexo, a generalização que a criança faz é muito semelhante à forma empregada pelo adulto em sua atividade intelectual. No entanto, externamente, a criança faz uma associação do tipo por complexo, utilizando, para isso, características objetivas e concretas dos objetos, e não uma generalização abstrata, que é característica do pensamento por conceitos. Em termos externos, é possível constatar a formação de um conceito; no entanto, em termos internos, verificamos a existência de complexos. Essa diferença é que leva a constatarmos que estamos diante de pseudoconceitos.

A transição dos pseudoconceitos para conceitos verdadeiros ocorre de forma imperceptível pela criança, uma vez que, no início, os pseudoconceitos coincidem com os conceitos dos adultos. Apesar de o pensamento do adulto utilizar, essencialmente, o pensamento através de conceitos, ele não é completamente abandonado.

Esse sistema de complexos fundamenta as generalizações que aparecem no pensamento da criança. A fim de estudar os conceitos, Vigotski (2001, p. 153) propôs um método que ele próprio denominou de sintético-genético, uma vez que estudou a formação do conceito, a partir de uma série de elementos que formam o próprio conceito, além do processo que o origina. A partir desses estudos 
empíricos, o pesquisador deparou-se com diversas fases do pensamento por complexos, até a formação do que ele chamou de pseudoconceito. O autor considera essas formações como conceitos potenciais.

Ele descobriu que o pseudoconceito constitui uma generalização que a criança faz, muito semelhante à forma empregada pelo adulto em sua atividade intelectual. No entanto, externamente, a criança faz uma associação do tipo por complexo, utilizando para isso características objetivas e concretas dos objetos e não uma generalização abstrata, que é característica do pensamento por conceitos próprio dos adolescentes.

A fim de guiar a nossa reflexão, trazemos as seguintes questões: $\mathrm{O}$ que é atividade? Como a atividade se estrutura? Como se dá a atividade educacional? Qual a relação entre atividade, consciência e personalidade? Qual o papel da motivação na atividade? Quais as etapas da formação da formação de conceitos? O que é o processo de interiorização? Como ele se dá? 


\section{4 \\ Teoria da atividade de A. N. Leontiev e a aprendizagem escolar}

La actividad del hombre no modifica historicamente su estrutura general, su "macroestructura". Em todas las etapas del desarrollo histórico se lleva a cabo a través de acciones conscientes em las cuales se efectúa la transicion de las metas a produtos objetivos y se subordina a los motivos que la estimulan. Lo que se modifica radicalmente es el carácter de las relaciones que ligan entre sí las metas y los motivos de la actividad. (LEONTIEV, 1984, P. 118)

A categoria atividade, utilizada na compreensão do homem como um ser social, remete-nos a Karl Marx ${ }^{61}$ e Friedrich Engels ${ }^{62}$. Através desses estudos, Marx utiliza o conceito de trabalho como fundamento do capital e como categoria ontogenética. Essas ideias fundamentaram o papel da atividade na constituição do psiquismo humano pela escola soviética. Elas são fundamentais na constituição das várias teorias que entendem a atividade como fundamento do psiquismo humano. Nos tópicos a seguir, abordamos a Teoria da Atividade de A. N. Leontiev, procurando destacar o papel da atividade escolar na constituição do psiquismo. Segundo Talízina, no caso da educação escolar, a aprendizagem constitui um dos tipos de atividade predominante. Sua particularidade consiste em que, durante a sua realização, o sujeito não tem nenhum outro objetivo que não seja a assimilação da experiência social (TALÍZINA, 2000, p. 56, tradução nossa).

A Teoria Psicológica Geral da Atividade ou unicamente Teoria da Atividade (TA) é um constructo teórico-metodológico edificado por Aleksei Nikolaievitch Leontiev (1903-1979) e seus colaboradores mais próximos A. V. Zaporózhets (1905-1981) e L. I. Bozhóvich, no começo dos anos de 1930, na cidade de Rharkov. Estas ideias aparecem mais desenvolvidas na sua mais conhecida obra, Atividade, Consciência e Personalidade $(1978,1983,1984)^{63}$,

\footnotetext{
${ }^{61}$ A primeira ideia do papel do trabalho na constituição do homem se encontra na obra de Karl Marx, escrita em 1844, "Manuscritos filosóficos e econômicos". Essas ideias aparecem em quase todas as obras do autor, sendo enormemente desenvolvidas na sua maturidade, em "O capital", publicada em 1867.

${ }^{62}$ No caso de F. Engels, destacamos a obra "Sobre o papel do trabalho na transformação do macaco em homem", datada de 1876.

${ }^{63}$ Tivemos acesso a três edições da obra de A. N. Leontiev, "Actividad, conciencia y personalidad" (1974), em língua espanhola: argentina (1978); cubana (1983); e mexicana (1984); além de uma edição de domínio público, em língua portuguesa - Brasil (1978). A partir de nossa
} 
cujos principais fundamentos são a constituição histórica da relação homemmundo e a indispensável e fundamental mediação instrumental. Nas palavras do próprio autor: "nas crianças a atividade objetivada adquire uma estrutura instrumental, enquanto que a comunicação se torna verbal, por intermédio da linguagem" (Leontiev, 1983, p. 170, tradução nossa).

Para ele, a relação que as crianças muito pequenas estabelecem com as coisas é sempre mediada pelas pessoas que as circundam. Em outras palavras, a atividade aparece cada vez mais realizada por meio dos vínculos da criança com as pessoas, através dos objetos. Assim, com a mediação instrumental, amplia-se o psiquismo, com o desenvolvimento da linguagem e a formação dos conceitos. As ideias de Leontiev são consideradas inovadoras porque, ao contrário das psicologias voltadas aos processos de desenvolvimento especificamente internos, ele propõe uma correlação entre a atividade interna e externa. Esse processo de interiorização das atividades externas está relacionado àquelas propostas por Vigotski (1931) e seus colaboradores.

Nos primeiros anos da Revolução Russa, houve uma intensa e frenética alteração nas bases das ciências soviéticas, uma vez que as mudanças na sociedade e nos modos de produção, naquele momento, exigiam mudanças na lógica do pensamento dos intelectuais, de modo a colaborar com os processos em vigor. Foi a partir desse movimento que apareceram os trabalhos do grupo de Vigotski, cujo objetivo era produzir uma psicologia geral, fundamentada no materialismo histórico e dialético.

Apesar de Marx não ter produzido uma teoria psicológica, muitos dos seus constructos foram utilizados para erigir a psicologia histórico-cultural e, por conseguinte, a Teoria da Atividade de Leontiev. A ideia de atividade como fundante do psiquismo humano é vastamente encontrada na obra de Marx, mesmo considerando que o seu objetivo não era produzir uma teoria do psiquismo.

De muitas maneiras, ele defende a atividade prática humana como a base da construção da consciência e da individualidade humana. Sob a perspectiva da sua ontologia, o psiquismo humano foi forjado através da atividade de trabalho. $\mathrm{O}$

análise, optamos pela cubana, por considerá-la mais fiel à obra do autor, uma vez que foi traduzida diretamente do original em russo. Entendemos ser fundamental a leitura dessa obra para a compreensão da Teoria Geral da Atividade. 
sentido de trabalho de $\operatorname{Marx}^{64}$ é a base que fundamenta a ideia de atividade de Leontiev. O trecho a seguir esclarece melhor essa ideia:

O trabalho é, antes de tudo, um processo entre o homem e a natureza, processo este em que o homem, por sua própria ação, medeia, regula e controla seu metabolismo com a natureza. Ele se confronta com a matéria natural como com uma potência natural [Naturmacht]. A fim de se apropriar da matéria natural de uma forma útil para sua própria vida, ele põe em movimento as forças naturais pertencentes a sua corporeidade: seus braços e pernas, cabeça e mãos. Agindo sobre a natureza externa e modificando-a por meio desse movimento, ele modifica, ao mesmo tempo, sua própria natureza. (MARX, 2013, p. 327)

O trabalho, conforme o autor, constitui a própria essência do homem, e é a atividade segundo a qual o homem é forjado. Portanto, a sua essência provém da relação que ele estabelece com as coisas da natureza. Diferentemente dos animais, o homem transforma a natureza para conseguir as condições de sua existência. Para Leontiev ${ }^{65}$ (2013, [?], tradução nossa), o trabalho mediante instrumentos coloca o homem não somente diante de objetos materiais, mas também frente às interações. A atividade, vista dessa maneira, se dá num processo de intercâmbios com outros homens.

Consideramos oportuno elencar as seguintes questões a serem elucidadas neste capítulo: O que é atividade? Qual é a sua estrutura? A estrutura da atividade externa é a mesma da interna? Qual a correlação entre atividade, personalidade e a consciência? Qual o papel do motivo e dos processos motivacionais para a sustentação da atividade? Qual o papel da atividade na constituição da vida mental do sujeito?

Conforme já exposto, a ideia de atividade como responsável pela gênese e a estrutura do psiquismo humano aparece nos escritos de Marx e Engels, sob a denominação de trabalho. O homem nasce homem como espécie (Homo Sapiens)

\footnotetext{
${ }^{64}$ Em sua obra O Capital - Livro I (1867), podemos encontrar diversos sentidos para atividade, geralmente com algum qualificativo: "atividade produtiva"; "atividade laboral"; "atividade orientada a um fim"; "atividade orientada à transformação"; "atividade artesanal"; "atividade operativa"; "atividade intelectual",etc. Nos manuscritos, conhecidos como Grundisse (1858), atividade aparece como: "atividade subjetiva"; "atividade criadora"; "atividade puramente abstrata"; "atividade formativa"; "atividade mediadora"; "atividade viva"; "atividade criadora" etc. ${ }^{65}$ “El hombre y la cultura", 1969. Texto obtido através de recurso eletrônico. Disponível em: $<$ https://omegalfa.es/downloadfile.php?file=libros/el-hombre-y-la-cultura.pdf $>$ Acesso em: 15 jun 2018.
} 
e evolui biologicamente desenvolvendo, no decorrer de sua filogenia, as características que o caracterizam como ser humano. A passagem do homem como espécie ao gênero humano é resultado de aquisições históricas, que não são incorporadas diretamente nele e nem em suas disposições naturais (genéticas). Para o autor, a fonte verdadeira que permite ao homem desenvolver seus poderes e aptidões resulta do desenvolvimento histórico-social, são os objetos que contêm em si a atividade das gerações anteriores, resultado do desenvolvimento intelectual da espécie humana (LEONTIEV, 2013, [?]) ${ }^{66}$.

O homem, através da atividade orientada a um fim, produz objetos que são úteis à manutenção de sua vida. No trajeto de sua existência, adquirem as funções especificamente humanas. Isso coloca-o nos ombros das gerações que o antecederam, elevando-o muito acima da espécie, através do que se conhece como cultura. Portanto, o ser humano, ao nascer, está hominizado, porém, não humanizado. O processo de humanização depende da apropriação da cultura em interação com outros indivíduos já "humanizados". Cada indivíduo, tomado à parte, aprende a se tornar homem. Viver em sociedade não é suficiente com o que a natureza dá no nascimento. Deve-se assimilar o que a humanidade alcançou no curso de seu desenvolvimento histórico. (LEONTIEV, 2013, p. 8, tradução nossa)

A Teoria da Atividade desenvolvida por Leontiev sofreu alterações e ampliações no decorrer do tempo. Conforme Longarezi e Puentes (2017, p. 8), muitos autores soviéticos deram continuidade às ideias de Leontiev, dentre os quais D. B. Elkonin (1904-1984), que estudou o problema da periodização do desenvolvimento psíquico na infância; Leonid V. Zankov (1901-1977), sobre o ensino e o desenvolvimento; A. V. Petrovsky (1924-2006) com relação à imaginação; P. Ya. Galperin (1902-1988) que trabalhou com a formação de conceitos e as ações mentais; V. Davydov (1930-1998), que estudou os princípios didáticos da escola tradicional e os princípios do ensino para o futuro; e, N. F. Talízina (1923), que se dedicou aos processos de formação da motivação escolar.

Para Leontiev responde à seguinte questão "O que é a vida humana?" (1984, p. 66) asseverando que "a vida humana é um conjunto, ou mais precisamente, um sistema de atividades que se substituem umas às outras". Para

${ }^{66}$ Esta citação de A. N. Leontiev, está no texto "El hombre y la cultura". Trata-se do terceiro capítulo do livro "El hombre nuevo", de 1969. O material digital não tem número de páginas. Disponível em: link <https://omegalfa.es/downloadfile.php?file=libros/el-hombre-y-lacultura.pdf $>$. 
ele, é na atividade que se tem a transição do objeto à sua representação subjetiva, que é a imagem. Por meio da atividade é que são produzidos os espaços de trocas entre os polos "sujeito-objeto" e é por meio dela que se objetiva a personalidade. A atividade é uma unidade da vida mediada pelo reflexo psíquico, cuja função real é de orientar o sujeito no mundo dos objetos.

Assim, para o autor, os processos psicológicos têm a ver com a atividade de indivíduos concretos, que transcorre das condições de uma coletividade aberta entre as pessoas que o rodeiam que interagem ou sozinha com o mundo circundante dos objetos (LEONTIEV, 1983, p. 67, tradução nossa). Ele sustenta que a introdução da categoria atividade na psicologia de sua época, assim como agora, suscitaria problemas teóricos que demorariam muito tempo para serem resolvidos.

O trabalho, conforme o entendimento de Marx, é a atividade fundante do ser social. Da mesma maneira que o homem modifica a natureza, a fim de produzir as condições de sua existência material, ele também modifica e produz a sua psique, portanto, ele foi forjado a partir das condições concretas de sua existência. A psique humana é derivada de elaborações coletivas e das relações sociais advindas dessas atividades.

Para Leontiev, o trabalho físico, que é responsável pelas transformações dos objetos, se tornou gradativamente mais "intelectual" ou mental. A atividade interna humana (cognoscitiva) é completada por atividades externas. Há um movimento constante entre a atividade externa e a interna. Estes movimentos somente são possíveis porque elas possuem uma mesma estrutura geral (LEONTIEV, 1983, p. 81, tradução nossa).

Afirmar que a atividade interna, por sua organização, se origina da atividade prática externa, não quer dizer que assim ela se afasta dela, mas que mantém uma relação fundamental e bilateral. Portanto, trata-se de uma relação dialética: aquilo que é internalizado também passa a ser externalizado, e viceversa. Apesar dessa constatação, na nossa sociedade, devido à divisão social do trabalho e à divisão em classes, a atividade interna ou intelectual é muito valorizada, em detrimento da atividade externa (prática) e, como consequência, adquire grande projeção.

Esta supervalorização da atividade interna em prejuízo da externa é consequência da histórica divisão da sociedade em classes sociais: nas classes 
mais baixas encontram-se os artesãos e, nas mais altas, os intelectuais, ou aqueles considerados nobres. Portanto, a nossa sociedade desde há muito tempo, é dividida entre aqueles que têm os saberes práticos e aqueles que possuem os saberes intelectuais. Isso pode ser facilmente verificado na concepção de escola e educação da nossa sociedade. À classe trabalhadora são oferecidas escolas onde os indivíduos se preparam para as atividades práticas; aos filhos da classe burguesa, detentora dos meios de produção, é reservado um saber mais 'intelectual'.

\section{1}

\section{Estrutura geral da atividade externa e interna}

A atividade contém componentes que formam uma estrutura composta pelos seguintes elementos: a necessidade (biológicas e/ou espirituais) $\rightarrow 0$ motivo $\rightarrow$ o objeto (motivo real) $\rightarrow$ e as condições para a sua execução. Toda atividade humana é direcionada a um objetivo. A unidade entre o objetivo e as condições conforma a tarefa ou a ação a ser executada. (LEONTIEV, 1983, p. 82, tradução nossa). Essas são as condições básicas para o desencadeamento de uma atividade. Um exemplo de Leontiev (1983, p. 83) clarifica a ideia: um sujeito está com fome (necessidade de comer) e pode satisfazer essa necessidade se buscar comida (objeto). Encontra-se motivado para a atividade de buscar comida quando sente a necessidade de comer e quando idealiza um objeto que possa satisfazê-lo. Propõem-se, então, objetivos: o que poderá fazer em termos de ações para satisfazer a sua necessidade?

Assim, uma atividade é constituída de uma série de ações e operações. Como vemos, a necessidade constitui o fator desencadeador da atividade; ela motiva o sujeito a ter objetivos e a realizar ações pertinentes. No caso da educação escolar, o produto da atividade do estudante são as novas possibilidades cognoscitivas e as novas ações práticas. Assim, a aprendizagem se dirige à satisfação de uma necessidade cognoscitiva (TALÍZINA, 2000).

No entanto, nem todo conjunto de ações forma uma atividade. Uma atividade configura-se, sempre, pela existência de uma necessidade. Ela constitui a categoria fundamental no materialismo histórico-dialético. A atividade prática 
sensorial dá origem ao desenvolvimento histórico-social dos seres humanos. Ela se caracteriza, principalmente, pelo seu caráter objetal.

Conforme Talízina ${ }^{67}$, tanto a atividade prática externa como a interna possuem uma estrutura análoga. A atividade interna representa uma atividade material, externa, modificada, evidenciando a relação dialética estabelecida entre a vida material ou social e o psiquismo.

Acerca das atividades com objetos, Leontiev (1983) define:

A atividade é uma unidade molar não aditiva da vida do sujeito corporal e material. E num sentido mais estreito, é dizer, que a nível psicológico, esta unidade da vida se vê mediada pelo reflexo psíquico, cuja função real consiste em que este, oriente o sujeito no mundo dos objetos. (LEONTIEV, 1983, p. 66, tradução nossa)

Dessa maneira, a atividade não é uma simples reação do sujeito ou tampouco um conjunto de reações, mas um sistema que possui uma estrutura de funcionamento, com ligações internas, conversões e acréscimos. Como atividade molar, o autor quer expressar a força da atividade na constituição do psiquismo. A realidade externa é objetivada e subjetivada pelo indivíduo, através do reflexo psíquico. É através da atividade que os sujeitos, na relação com os objetos, fazem a transição para a sua forma subjetiva, e nessa produção ele objetiva a sua personalidade. Esse sistema não é mecânico, como parece; o sujeito é ativo e consciente durante o processo.

Até agora foi apresentada a ideia de atividade sob uma perspectiva mais genérica. Porém, os seres humanos sempre estão em presença de atividades específicas. A princípio, o que desencadeia uma atividade é sempre uma necessidade do sujeito frente a determinado objeto. Para Leontiev (1961), a necessidade é um estímulo que promove a ação do sujeito:

A necessidade do organismo manifesta-se em uma excitabilidade que aumenta conforme determinadas influências. Nas formas mais simples, a excitabilidade aumenta de acordo com as influências diretas e incondicionadas, ou se já, no sentido daquelas que por si mesmas são capazes de mudar o estado do organismo na direção necessária (esta é, por exemplo, a influências das substâncias alimentícias sobre o organismo).

${ }^{67}$ Ibid., p. 18 
Nas formas mais complicadas e derivadas, a necessidade é a excitabilidade aumentada em relação às influências que por si mesmas não podem mudar o estado do organismo, mas que estão conectadas com influências diretas determinadas e desempenham em relação a elas uma função de sinal (este é, por exemplo, o tipo de excitabilidade aumentada que tem um animal faminto diante do cheiro ou da visão da comida). (LEONTIEV, 1961 in LONGAREZI \& PUENTES, 2017, p. $39-40)$

A necessidade de alimento, que chamaremos de primárias, é decorrente de uma programação natural do sujeito; são, portanto, incondicionadas. As necessidades, que no início da vida do sujeito são primárias, como a de alimento, vão se tornando cada vez mais complexas. Para uma criança muito nova, a satisfação de uma necessidade como a de alimento vai se tornando condicionada, pois lentamente será associada ao tipo de alimento oferecido, ao horário de alimentação, ao carinho recebido, etc.

No decorrer do tempo, essas necessidades adquirem tal complexidade que a sua satisfação segue por vias indiretas ou por caminhos nem sempre específicos. Mas de qualquer forma, diante de uma necessidade, produz-se um aumento na excitabilidade do organismo, preparando-o para a ação. O cheiro do alimento, a sua cor e a sua consistência provocam uma mudança no organismo, agindo como uma espécie de sinal excitatório. À medida que aumenta a relação do sujeito com o seu meio e as suas relações se tornam mais efetivas, ocorrem marcantes mudanças nas suas necessidades. Para Leontiev (1961):

[...] à medida que se complica a estrutura dos organismos, suas necessidades são mais complexas, mais ricas e variadas. Estas são, sobretudo, ricas e variadas no homem; nele adquirem novas particularidades qualitativas e estão submetidas a leis que atuam unicamente na vida social. (LEONTIEV in LONGAREZI \& PUENTES, 2017, p. 40)

Conforme os seres humanos vão ampliando as suas relações com os objetos, surgem novas e complexas necessidades. Leontiev considera que existe uma lei geral do desenvolvimento das necessidades no ser humano, que são de ordem sócio-histórica. A necessidade humana desenvolve-se à medida que a criança amplia o seu círculo de objetos e meios para satisfazê-la e sobre essa base ampliada de objetos e meios, se enriquece e se desenvolve a necessidade 
correspondente. No decorrer do desenvolvimento histórico dos seres humanos, apareceram necessidades que antes não existiam, de ordem material, superior ou espiritual, caracterizadas pelo seu caráter eminentemente social.

Para satisfazer às necessidades espirituais, como as da arte e do próprio conhecimento, são necessárias determinadas condições materiais como livros, instrumentos, o acesso à internet, etc. Por outro lado, as necessidades relacionadas à vestimenta, por exemplo, incluiriam exigências do tipo estético e do tipo social. O que distingue uma atividade de outra, então, é o próprio objeto da atividade. Leontiev considera que o objeto da atividade é o seu motivo (1983, p. 83, tradução nossa). Leontiev considera que o objeto constitui o seu motivo real; no caso da educação, o objeto é o conhecimento. Em síntese, uma atividade está sempre orientada a satisfazer uma determinada necessidade, que é satisfeita quando encontra o seu objeto e, por conseguinte, novas necessidades surgem.

No caso do processo educativo, o objeto, que é o que move o sujeito para a ação, não está muito claro. Isso explicaria, em parte, o desânimo dos estudantes em exercer a atividade de estudo. Ela não é vista como prazerosa, uma vez que não se percebe o seu motivo real. É claro que o motivo real seria a socialização dos conhecimentos historicamente produzidos pela humanidade, objetivando a formação do ser humano, mas que não está acessível à consciência da criança pequena.

Nesta investigação, percebemos que o estudante está alheio ao objeto de estudo ou desviado para objetivos postos por uma sociedade que valoriza o produto/mercadoria. Em consequência, ele, por vezes, não compreende exatamente o motivo de sua atividade, ou as ações e as operações propostas pelas professoras. Por vezes, os estudantes ouviram das professoras que o ato de estudar tem por finalidade a preparação para o trabalho ou então para realizar uma avaliação que lhe permitia a entrada num curso superior, e assim, se preparar melhor para o exercício do trabalho.

Uma atividade é formada por um conjunto de várias ações, como vimos. Essas ações são desencadeadas pela necessidade e mantidas pelos seus motivos. Concordamos com SFORNI (2003), que expõe que, no processo de ensino, as ações são sistemática e intencionalmente desencadeadas, permitindo identificar indícios de mudanças na qualidade do pensamento. O instrumento regula as ações sobre os objetos, assim como o signo regula as ações sobre o psiquismo das 
pessoas. Os instrumentos psicológicos têm a função de ampliar as ações do psiquismo, porque potencializam as capacidades, como a linguagem, a memória, o pensamento, a atenção e o raciocínio lógico.

Assim, o homem desenvolveu a capacidade de sair dos limites do reflexo imediato da realidade perceptiva para refletir o mundo em suas relações complexas e abstratas. Isso só se tornou possível devido ao desenvolvimento das atividades que levaram à sua generalização e categorização. Esse sistema de atividades desenvolvidas pelo homem no mundo material permitiu que ele transpusesse da vida das simples relações sensoriais com os objetos para o mundo simbólico.

Para Leontiev,

O surgimento das ações na atividade e de processos orientados para um objetivo tem sido historicamente consequência da passagem do homem à vida em sociedade. A atividade dos participantes de um trabalho conjunto é estimulada pelo produto da mesma, que primariamente responde de uma forma direta as necessidades de cada sujeito. (LEONTIEV, 1983, p. 83, tradução nossa).

Neste trecho, Leontiev pondera que a atividade é sempre orientada e estimulada por um motivo. Por conseguinte, o motivo está sempre ligado ao objetivo que é o objeto real da atividade. Por exemplo, as atividades didáticas se manifestam pelas ações voltadas aos atos de aprendizagem e de comunicação, tão necessárias à sua efetivação. A coincidência entre os motivos da atividade (ações) e o seu objeto compõem o processo de aprendizagem. Leontiev entende que nem sempre a atividade e a ação são coincidentes entre si, pois uma mesma ação pode tomar parte de diferentes atividades, podendo até passar de uma atividade a outra.

No caso da atividade de aprendizagem, o estudante se vê frente a uma exigência de realização de várias ações ou atos, mas, muitas vezes, ele não compreende a finalidade ou as suas ligações, pelo fato de que elas pertencem a um conjunto de atividades. Cabe ao professor auxiliar o estudante nesse processo de conscientização das finalidades da atividade. As ações ou os atos, porém, nem sempre são coincidentes com a atividade.

Sobre isso, Leontiev pontua: 
[...] a atividade é realizada regularmente mediante certo conjunto de ações, subordinadas a objetivos parciais, que podem ser deduzidos do objetivo geral; nesse caso, o que caracteriza os graus superiores de desenvolvimento consiste em que o papel do objetivo geral é realizado por um objetivo consciente, que se transforma, em virtude de seu caráter consciente, em um motivo-objetivo. (LEONTIEV, 1983, p. 85, tradução nossa)

No caso do processo de aprendizagem, o objetivo geral é conhecido, pois é evidenciado no próprio papel atribuído à escola, que é o da transmissão de conhecimentos. Desse modo, as atividades realizadas são variadas, consistindo de diferentes ações, que devido ao seu caráter consciente, transforma-se no orientador da atividade ou em seu motivo. Assim, o objetivo da atividade do estudante sempre estará ligado à sua ação, e é através dela, que o sujeito pode compreender os objetivos de sua atividade.

Pensando em seu contrário, que é quando a atividade está separada dos seus motivos, o estudante não se sente determinado a realizar as ações e operações propostas pelo professor. Quando ele o faz, é de forma mecânica e não consciente e, como resultado, o processo de assimilação do conhecimento fica prejudicado. A ação que o sujeito realiza responde a uma tarefa, a um objetivo, dados em condições determinadas ou planejadas. Caso isso não ocorra, tanto a atividade como os objetivos ficam prejudicados. Essa separação tem como consequência a alheação dos sujeitos.

As operações não estão separadas das ações: compara-se à ligação que existe entre as ações e a atividade. Uma ação é composta de múltiplas operações. As operações são dependentes das condições que se desencadeiam no fluxo geral da atividade, que principia com a necessidade, passando pela atividade, que se manifestam em ações e, finalmente, nas operações para a realização dos objetivos. Essas unidades da atividade humana constituem, em seu conjunto, a macroestrutura da atividade, mediada pelo reflexo psíquico. A atividade cognoscitiva é um tipo de atividade de caráter essencialmente interno, mas que pode responder a um motivo externo e vice-versa.

Leontiev chama atenção para o estudo da atividade a partir de suas "unidades" componentes como forma de compreender o seu desenvolvimento ${ }^{68}$.

${ }^{68}$ Id., p. 43. 
Ao discriminar as "unidades" da atividade, o professor pode articular as ações e operações, de modo que o estudante perceba as relações que existem entre elas e, assim, disponibilize as suas energias afetivas ou as suas disposições internas para a atividade e o desenvolvimento do interesse.

Conforme expusemos, os elementos que motivam o sujeito à atividade são de ordem interna, em sinergia com o externo. Os motivos estão ligados à atividade e ao objeto que, segundo Leontiev, podem ter existência real ou ideal. Até agora, referimo-nos basicamente àqueles de ordem ideal, ou seja, que estão presentes na mente. Mas os próprios objetos da atividade podem se tornar estimuladores da atividade e de seu(s) objetivo(s).

Sobre isso Leontiev, discute:

Os próprios objetos podem adquirir a condição de excitadores de objetivos, de instrumentos no sistema de atividades humana; retirado desse sistema de relações, os objetos perdem a condição de excitadores, de objetivos, de instrumentos. (LEONTIEV, 1983, p. 89, tradução nossa)

$\mathrm{Na}$ atividade educativa, os objetos são, na maioria, de ordem abstrata, como ideias, proposições e conceitos. Não obstante, muitas vezes os estudantes se deparam com objetos que têm existência física real, utilizados para a compreensão de uma generalização. Leontiev compreende que esses objetos podem tomar a posição de excitadores ou motivadores, atuando nos aspectos da disposição do estudante para a atividade. Dessa forma, o objeto adquire o caráter de motivo da atividade.

$\mathrm{Na}$ próxima seção, analisaremos o papel do motivo e dos processos motivacionais no processo cognoscitivo, que será abordado em sua unidade.

\section{2}

\section{O papel do motivo e os processos motivacionais}

É indubitável a relação entre os processos cognoscitivos e motivacionais. A atividade não pode existir sem um motivo; não existe atividade não motivada. Concordamos com Leontiev, para quem a atividade tem um motivo, que pode estar aparente, ou trazer em si um motivo oculto, não percebido pelo sujeito, Os aspectos motivacionais estão ligados aos aspectos afetivo-volitivos, ou seja, aos aspectos ligados às emoções, que promovem as disposições para a atividade. 
Trazemos aqui algumas indagações que procuraremos responder no decorrer desta seção: O que são as emoções? Qual o seu papel? Como elas aparecem? Quais são os seus componentes? Qual é a papel da motivação nos processos de ensino-aprendizagem?

Em relação à emoção, abraçamos a definição de Vigotski:

Toda emoção é um chamamento à ação ou renúncia a ela. Nenhum sentimento pode permanecer indiferente infrutífero no comportamento. As emoções são esse organizador interno das nossas reações, que retesam, excitam, estimulam ou inibem essas ou aquelas reações. Desse modo, a emoção mantém seu papel de organizador interno do nosso comportamento. (VIGOTSKI, 2004, p. 139)

Devido ao seu caráter de organizar o comportamento, a motivação e as emoções são essenciais para os professores, uma vez que, ao se ter consciência de sua existência, podem se tornar extraordinárias aliadas no processo de ensino. Vigotski (2004, p. 140) compreende que é possível a educação do sentimento. Para ele, como educar sempre significa mudar, todo sentimento envolve um mecanismo de reação, ou seja, certa resposta do organismo a algum estímulo dado através do meio.

No processo de ensino, ao estabelecer estímulos diversos, podemos criar novos estímulos orientadores da ação. Para o autor, as reações emocionais devem constituir a base do processo educativo. Antes de comunicar esse ou aquele sentido, o professor deve suscitar a emoção do estudante e preocupar-se com que essa emoção esteja ligada ao novo conhecimento.

Muito embora Vigotski não tenha construído um corpus de conhecimento sobre emoção ${ }^{69}$, em seus últimos escritos, como a "Teoria das emoções", inacabado devido à sua morte prematura, ele mantinha uma grande preocupação com essa função psicológica (TOASSA, 2009, p. 149). De acordo com a autora, a discussão sobre o que é emoção e sobre o seu papel aparece de forma esparsa em seus vários trabalhos. Ela destaca o texto "A educação dos sentimentos" como o mais denso sobre a problemática.

\footnotetext{
${ }^{69}$ Segundo Prestes (2010), Vigotski deixou um conjunto de manuscritos inacabados sobre a temática da emoção. O autor nutria um profundo interesse pela filosofia de Espinoza e desejava, conforme indicam esses manuscritos, desenvolver melhor o tema das emoções. O título provisório foi modificado por ele de "estudos das emoções" para "Espinoza e o estudo das emoções".
} 
Nem mesmo Leontiev produziu uma teoria sobre motivação que abrangesse toda a sua dimensão. Na Teoria da Atividade, a motivação faz parte da macroestrutura da atividade, mas ele não se aprofundou no assunto. Segundo Vigotski, é preciso pensar as emoções nos seus aspectos biológicos e culturais como uma unidade dialética. Para isso ele destaca, mesmo contraditoriamente, a filosofia de Espinoza $^{70}$ (1632-1677): o monismo espinosiano, principalmente aquele da "Ética" conjunto das funções psicológicas superiores.

Este trecho de González Serra fala da relação entre os aspectos motivacionais e os aspectos cognoscitivos:

Portanto, o estudo da cognição está incompleto se não se levar em conta, toda a importância que a afetividade tem nela e igualmente, o estudo da afetividade e da motivação não está completo se não se estuda a importância que tem os fatores cognoscitivos nelas. A investigação da personalidade humana tem pecado igualmente de limitar-se ao estudo do caráter e dos fatores relacionados á motivação. A teoria da personalidade será mais adequada na medida em aborde a unidade do cognoscitivo e afetivo. $\mathrm{O}$ cognoscitivo e o afetivo são duas faces inalienáveis do psiquismo humano, que se condicionam e produzem um a outro. O cognoscitivo somente surge e se desenvolve em virtude das necessidades e para satisfazê-las. Por sua vez, as necessidades do ser humano e sua estrutura motivacional e de sua personalidade só podem ser compreendidas em seu desenvolvimento, em virtude das transformações cognoscitivas. $\mathrm{O}$ cognoscitivo surge em virtude e em dependência do afetivo e vice-versa. (GONZÁLEZ SERRA, 2008, p. 28, tradução nossa)

Vimos que a motivação está ligada aos processos afetivo-volitivos; o cognitivo brota e se desenvolve em virtude das necessidades do indivíduo. O autor chama a atenção para a necessidade de compreensão da motivação a partir do acompanhamento do desenvolvimento das funções cognitivas. Elas não devem ser apreendidas de forma dissociada.

\footnotetext{
70 O livro "Ética", de Baruch de Espinoza, está organizado segundo um método axiomáticodedutivo, inspirado na geometria euclidiana, visando a garantir a certeza dos resultados, embora à custa de uma leitura não especialmente fácil. A obra, acentuadamente sistemática, propõe-se tratar todos os campos de investigação da filosofia, dividindo-se em cinco partes (sobre Deus, a mente, as paixões, a escravização do homem em relação a estas e a possibilidade da sua libertação delas), que correspondem a um percurso que, partindo das questões mais fundamentais da metafísica, e passando pela teoria do conhecimento, chega por fim à ética, com o objetivo preciso de formular uma teoria da felicidade humana. Fonte: 〈https://pt.wikipedia.org/wiki/\%C3\%89tica_(Espinoza)>. Acesso em: 25/09/2017.

${ }^{71}$ O texto "Ėtica" foi publicado postumamente no ano de 1677.
} 
Para González Serra, a motivação se define como

[...] o conjunto encadeado de processos psíquicos (que implicam atividade nervosa superior e reflexa da realidade objetiva através das condições internas da personalidade) que ao conter o papel ativo e relativamente autônomo e criador da personalidade, em sua constante transformação e determinação recíprocas com a atividade externa, objetos e estímulos, são dirigidos a satisfação das necessidades do ser humano e, como a consequência, regulam a direção (objeto-meta) e a intensidade ou ativação do comportamento, e se manifestam como atividade motivada. (GONZÁLEZ SERRA, 2008, p. 52, tradução nossa)

O autor expõe a relação inseparável entre a atividade do sujeito e a motivação. Para ele, as atividades externas são direcionadas à satisfação das necessidades, tendo como consequência tanto a regulação da direção quanto da intensidade do comportamento para a satisfação da necessidade.

$\mathrm{O}$ processo educativo engloba um conjunto de atividades dirigido a metas. A relação que se estabelece entre os motivos e a necessidade deve ser estreita. Quando isso não ocorre, o sujeito fica alienado dos processos que deveriam propiciar a sua ação.

Nossa pesquisa apontou que as ações e operações propostas pelas professoras raramente promovem o engajamento do estudante no processo de aprendizagem, visto que não estão ligadas à satisfação das suas necessidades. Temos, como hipótese, que as professoras não têm a clareza disso, o que acaba por se consolidar em suas ações. Desse modo, os estudantes estão alheios ao processo que definem as metas.

A motivação desperta, inicia e mantém o sujeito nas atividades, aumentando ou diminuindo a intensidade do seu comportamento e até colocando fim a ele, assim que as metas são atingidas. Também é preciso ter em mente que a personalidade, vista aqui como uma construção social, exerce um papel preponderante sobre a motivação do sujeito para a atividade, uma vez que são indissociáveis. Concordamos com González Serra em suas ponderações:

A motivação é por vez, um reflexo da realidade e a expressão da personalidade. Os estímulos e situações que atuam sobre o sujeito, se refratam através das condições internas da personalidade, por isso, a motivação é uma expressão e uma manifestação das propriedades e do estado da personalidade: do 
caráter, das capacidades cognoscitivas e do temperamento; porém as propriedades do caráter são as que ocupam nela a função principal. (GONZÁLEZ SERRA, 2008, p. 53, tradução nossa)

Através da nossa investigação, percebemos o quanto é crucial o papel da motivação extrínseca, que muitas vezes se mostrou ausente nas aulas. O autor descreve que a motivação é externa em sua origem e internalizada pelo sujeito. São derivadas das situações estabelecidas, a priori, pelo processo de ensino, sem prescindir do papel relevante da personalidade de cada sujeito no processo.

González Serra (2008, p. 54) explica, com muita propriedade, que "a motivação não se encontra somente nos processos psíquicos do sujeito, mas também se manifesta na direção e intensidade dos seus atos materiais externos, frente a determinados estímulos e situações". Assinalamos o papel do professor como primordial mediador e organizador das situações de aprendizagem, com o propósito de produzir as condições e estímulos externos para que se processe o ato motivacional.

As transformações na personalidade dos adolescentes são facilmente constatadas pelos adultos, uma vez que se manifestam através da sua conduta. Além da formação dos verdadeiros conceitos, é na adolescência que a motivação se torna autônoma, que atua como fim, como projetos a serem executados e como sentimento.

Por motivação autônoma, González Serra ressalta:

A motivação autônoma pode atuar como conviç̧ão, como propósito ou projeto, ou ainda como sentimento. Nela tem especial importância a aspirações (os ideais e intenções). O sujeito elabora pessoalmente as suas aspirações e dirige sua atividade para a realização das mesmas, tanto para obter a imagem ideal que aspira para si, como para realizar seus projetos autônomos dirigidos para o futuro. Aqui, desempenha uma importantíssima função a auto valoração de si, orientada para a realização dos ideais ou das intenções que o indivíduo se propõe. (GONZÁLES SERRA, 2008, P. 64, tradução nossa)

A motivação não é mais tão dependente da atividade externa, mas se transforma em uma atividade da própria consciência. $\mathrm{O}$ adolescente experimenta a decisão de se colocar em atividade, conforme uma decisão de sua própria 
consciência, e sente os resultados dessa decisão, pois se vê capaz de exercer a autorregulação do seu comportamento. A motivação torna-se intrínseca a ele: essa é a motivação autônoma, que se torna parte do sujeito, de sua intimidade e de sua individualidade.

Dessa maneira, a atividade de estudo voltada à realização profissional ou ao conhecimento do/sobre o mundo dá-se conforme a decisão do próprio sujeito. Ao estar convencido de que suas ações estão voltadas a satisfazer as exigências para a consecução de determinado objetivo, o estudante executa as operações propostas. Como ensina Leontiev (Leontiev, 1961 in Longarezi e Puentes, 2017, p. 40), a atividade voltada à consecução dos objetivos estimula à ação, podendo produzir excitabilidade, o que promove o desenvolvimento de suas disposições. Por exemplo, ao ler um livro independentemente de ser o conteúdo de uma avaliação, o objeto sobre o qual a ação se dá se torna o seu motivo real.

Uma vez que fique claro aos estudantes o real motivo de sua atividade de instrução, ficará mais espontânea a realização do objetivo do processo de ensino, que é a transmissão de conhecimento das gerações que nos antecederam para as gerações que nos sucederão.

\section{3 Contribuições da Teoria da Assimilação das Ações Mentais de P. Ya. Galperin e N. F. Talízina para a formação de conceitos}

Piotr Yakovlevich Galperin (1902-1988) foi contemporâneo de A. N. Leontiev na escola de Rharkov. Ambos foram continuadores das ideias de Vigotski. Galperin faz parte da segunda geração ${ }^{72}$ que, segundo Shuare (2016, p. 150), foram os colaboradores mais diretos de Leontiev. Seus estudos foram principalmente sobre o objeto da psicologia e os métodos para o seu estudo.

Para Shuare (2017, p. 146), o processo de "degelo na psicologia" começou na URSS nos anos 1050, com a retomada da Teoria histórico-cultural e da Teoria da Atividade. Tal fato se intensificou a partir do ano de 1962, com a ocorrência um importante encontro ou Seção promovido por diversas associações: Seção de Psicologia do Instituto de Filosofia da Academia de Ciências Médicas; Academia

\footnotetext{
${ }^{72}$ Conforme Shuare (2017, p. 198), P. Ya. Galperin é um representante da segunda geração da Psicologia Histórico-Cultural, juntamente com A. Leontiev, A. Luria, D. Elkonin, A. V. Zaporozhetes, L. Bozhóvich, N. Morozova, R. E. Levina, S. slavina etc.
} 
de ciências médicas; Academia de ciências pedagógicas e Ministério da educação superior e médio. $\mathrm{O}$ evento em questão teve como tema: Os problemas filosóficos da fisiologia da atividade nervosa superior e a psicologia.

Nesse evento, pouco conhecido, participaram cerca de 1000 cientistas, representando diversos institutos, de mais de 40 cidades. Numa das Seções, foi apresentado um informe de Leontiev e Pánov e, dentre os temas, um estudo desenvolvido por Galperin, Talízina, Elkonin e Davidov sobre os problemas das ações mentais e dos processos de interiorização e exteriorização, que confirmaram o princípio comum da estrutura das atividades externa e interna.

A proposta de Galperin fundamenta-se principalmente no método utilizado por Vigotski, que se baseia na análise dos fenômenos do pensamento através de suas unidades. No texto "Sobre la investigación del desarrollo intelectual del niño"73, publicado em 1969, o autor discute as suas ideias sobre o desenvolvimento do psiquismo em crianças. Seus estudos são relacionados, especialmente, aos processos de assimilação da atividade através da interiorização das ações por etapas. Segundo o autor, (Galperin in Shuare, 1987, p. 126) sua teoria é conhecida como Teoria da Assimilação das Ações Mentais por Etapas.

Suas ideias tratam do processo de apropriação de conceitos e habilidades, e também da incorporação de novas qualidades aos conhecimentos e habilidades que o sujeito já possui. Seus estudos apontam para a necessidade de transformação social; refletem sobre o papel da educação nesse processo, tendo em conta o contexto em que foram elaborados - a revolução socialista. Apoiam-se nos fundamentos do materialismo histórico e dialético, que consideramos fecundo para esta investigação.

Em nossa opinião, as pesquisas desenvolvidas por ele têm enorme efetividade para educação, pois basearam-se em estudos realizados principalmente no âmbito escolar. Esses estudos estão em sintonia com as ideias desenvolvidas por Davidov $^{74}$, quando enfatizou a relação dialética entre os processos de desenvolvimento e os princípios didáticos da escola tradicional (Davidov in LONGAREZI \& Puentes, 2017, p. 143).

\footnotetext{
${ }^{73}$ Sobre a investigação do desenvolvimento intelectual da criança.

${ }^{74}$ Vasily Vasilyevich Davidov (1930-1998) faz parte da terceira geração da escola de Vigotski. Dedicou-se especialmente ao estudo dos princípios didáticos da escola e do ensino.
} 
Assim, Galperin, Zaporozhets e Elkonin (in Shuare, 1987, p. 314, tradução nossa) diferenciam três tipos de aprendizagem: (1) numa fase muito nova, são apresentados objetos à criança, que interage com eles, espontaneamente e, por si mesma, busca os elementos orientadores da tarefa. É uma ação baseada no ensaioerro de forma pouco consciente. Suas características são a casualidade, a inconstância, sendo muito suscetível ao esquecimento; (2) nesse segundo tipo de aprendizagem, a criança já consegue seguir as orientações e indicações necessárias à execução da atividade e, assim, a executa de forma correta. Sua atividade baseia-se na orientação recebida. Os elementos orientadores são adquiridos de forma empírica, isto é, por demonstração. Seu aprendizado se dá com base na memória; (3) no terceiro tipo, a aprendizagem se dá pela utilização de um método de análise do objeto, o que lhe permite um sistema de orientação para as suas ações.

Esse sistema de orientação das ações é adotado para resolver problemas relacionados a outras situações similares. Esse tipo de aprendizagem leva à formação de guias de orientação, influenciando diretamente o desenvolvimento intelectual. Esta última forma de conceber a aprendizagem constitui um dos elementos fundamentais da proposta desenvolvida por Galperin, que será discutida na sequência deste texto.

Luria (1981) evidencia, a partir de Galperin (1959 apud LURIA, 1981, tradução nossa), que a gênese dos processos mentais complexos começa com uma série expandida de ações externas sucessivas (tentativas e erros), progride para uma fala interna expandida, na qual se fazem as necessárias buscas, e termina com a contração e condensação dessas buscas externas e com a transição para um processo interno específico.

Para Galperin (Galperin in Shuare, 1987, p. 125, tradução nossa), a atividade psíquica é acessível somente em seu processo de formação dirigida, entendida como orientação de diversos tipos, que se dá por transformações paulatinas na organização psíquica, oriundas da atividade material. Nosso entendimento é que esse modo de explicar o processo de constituição do psiquismo tem implicações sobre o processo ensino-aprendizagem, especialmente no que se refere à atividade pedagógica. Ainda conforme Galperin, tanto na escola como na vida, as ações não se realizam meramente pelo gosto em realizá-las, mas 
para obter um determinado resultado. Elas estão direcionadas a uma finalidade e, por consequência, a certos objetivos.

Seus estudos representam uma inovação nas pesquisas sobre ensinoaprendizagem, pois o foco é deslocado da formação da ação para as condições que assegurem a sua formação. Os resultados não estão baseados na análise do produto do processo ensino-aprendizagem, mas na orientação das ações. Cabe ao professor orientar as ações dos estudantes para que atuem adequadamente e assimilem os conceitos.

Para o autor, existe uma unidade indissociável entre atividade e a estruturação do psiquismo humano. Com essa proposição, percebemos a estreita vinculação entre as ideias desse estudioso e a Teoria da Atividade de Leontiev. Ao estudar os processos de ensino, ele chegou à conclusão de que os processos analisados pelo grupo de Vigotski, sobretudo a mediação e a interiorização, poderiam ser operacionalizados e incorporados aos métodos de ensino.

Galperin (Galperin in Shuare, 1987, p. 129, tradução nossa) foi o idealizador de um método de estudos do psiquismo denominado de Método da Formação por Etapas das Ações Mentais. Para ele, somente a organização da formação por etapas de ações mentais e conceitos abre a possibilidade de estudar o desenvolvimento intelectual de forma dinâmica, em relação ao jogo de forças que movimentam e seus mecanismos constitutivos. Segundo o autor, a ação inclui as partes de orientação, de execução, de controle e de correção. Ele destaca que a parte e orientadora da ação aprendizagem é que determinam a rapidez e a qualidade da ação. A parte orientadora dirige-se à construção correta e racional da execução e à seleção de uma das possíveis formas de execução das tarefas propostas pelo professor (TALÍZINA, 2000, p. 148).

Conforme atesta Shuare (2016, p. 151), a grande questão levantada por Galperin foi: “o que são os processos psíquicos?”. A resposta que ele propõe é que se referem a um processo que principia quando o indivíduo executa uma atividade externa. Em sua forma inicial e fundamental, essas ações práticas são assimiladas pelo sujeito e permitem, posteriormente, o desenvolvimento das funções psíquicas superiores. Portanto, os processos psíquicos têm sua gênese através de ações externas correspondentes, produzindo as ações mentais. Outra questão que se faz é: “mas o que são as ações mentais?” O próprio autor explana: 
Toda ação caracteriza-se, antes de tudo, pelas variações que produz em seu objeto e pelo resultado ao qual conduz. Igualmente, a ação mental caracteriza-se por sua variação determinada e por seu caráter dirigido a um fim. Porém, aqui o objeto é mental. Por isso, a ação mental pode ser determinada como a habilidade de realizar mentalmente uma transformação determinada no objeto. (GALPERIN, 1959 in LONGAREZI \& PUENTES, 2016, p. 199, tradução nossa).

Assim sendo, as ações primeiramente são externas e depois são assimiladas e convertidas em ações mentais. As ações mentais são os reflexos derivados das ações materiais. Galperin (Galperin, 1969 in Shuare, 1987, p. 130, tradução nossa) defende que as habilidades mentais de lidar, por exemplo, com cálculo simples, diferenciar uma palavra em seus sons componentes, ler uma palavra escrita, determinar o estilo de uma obra etc., são exemplo de ações mentais. Essas ações mentais passam a constituir as habilidades decorrentes da aprendizagem.

Os estudos de Galperin auxiliam na apreensão do processo educativo e da formação de conceitos, pois se concentraram especialmente no ambiente escolar. Segundo ele, (Galperin, 1959 in Longarezi \& Puentes, 2017, p. 151) o processo pedagógico - entendido em seu sentido amplo e não somente no escolar - é a realidade autêntica em que o psiquismo se forma e se amplia; apenas nesse processo pode-se compreender a origem, o conteúdo e a natureza do psiquismo.

Apoiando-se na Teoria da Atividade de Leontiev, Galperin defende que as ações, que são os principais componentes de uma atividade, se produzem não somente pela vontade em realizá-las, mas devido a um objetivo. Frisa que as ações humanas estão sempre direcionadas a satisfazer uma determinada necessidade e seus objetivos. No caso das ações das crianças, que a princípio são objetais, há uma base, que serve de orientação. São constituídas de duas partes fundamentais: a compreensão e a capacidade. A compreensão desempenha a função de base de orientação para a execução da ação ou do conjunto de ações. A capacidade refere-se às competências já desenvolvidas, que devem ser conhecidas pelo professor, para que o sujeito capte a orientação da atividade.

Para o autor, a orientação das ações pelo professor deve incluir três momentos: (1) a composição do quadro das circunstâncias da ação; (2) o esboço do plano de ação; e (3) o controle e a correção da execução da ação. A execução da ação dá-se através da capacidade; depende da base orientadora, porém não se 
reduz a ela. A parte orientadora, que é a compreensão da ação, constitui a instância diretiva, fundamental para a qualidade da execução da ação.

Assim, o primeiro passo é criar as situações ou o ambiente para que as ações e as operações ocorram. O segundo é oferecer as orientações detalhadas de como proceder nessas atividades, de modo que se eliminem os equívocos das ações. O terceiro momento envolve o controle da habilidade a ser formada, que deve ocorrer sistemática e processualmente. Esse método trata de prover o estudante de um método, para que ele o utilize em qualquer outro momento que envolva estudos semelhantes na área, formando uma base orientadora de suas próximas ações. A apropriação do conceito e da habilidade formam uma unidade, a partir do planejamento, da execução e do controle intencional do professor.

$\mathrm{O}$ autor sugere que o professor realize um estudo inicial sobre as unidades fundamentais da sua área (conteúdos e conceitos), além de dar atenção às regras gerais e às combinações para os fenômenos concretos. Assim, os estudantes vão dominando os objetos e métodos da nova área de estudo, separando os objetos concretos em unidades fundamentais e realizando a caracterização de suas combinações. Em resumo, é sobre essa base orientadora que se dá a assimilação das ações e conceitos ligados ao objeto estudado.

A função do professor passa a ser introduzir ao estudante uma apropriada Base Orientadora da Ação - BOA. Compete ao professor o planejamento minucioso da ação educativa, com vistas à construção dos conceitos. $\mathrm{O}$ sucesso na execução de uma determinada atividade pelo sujeito depende da orientação recebida. Essa orientação constitui a base para a execução das ações mentais, exercendo a função de instância diretiva fundamental das ações e operações no mundo material e não material.

A Base Orientadora é fundamentada na ideia de Vigotski de Zona de Desenvolvimento Iminente, que aponta para a potencialidade do ser humano em adquirir conhecimento com a ajuda, direção e explicação de outro indivíduo mais desenvolvido. Sendo assim, Galperin propõe uma série de etapas que reputa como fundamentais no processo de formação de uma ação interna ou do ato mental (Galperin, 1959 in Longarezi e Puentes, 2016, p. 200):

1. Etapa motivacional;

2. A formação de uma Base Orientadora da Ação; 
3. A formação do aspecto material dessa ação;

4. A formação de seu aspecto linguístico; e

5. A formação dessa ação como um ato mental.

A primeira etapa tem a função de motivar os estudantes para a ação, a fim de garantir a atenção dos estudantes, preparando-os para as etapas posteriores. Uma das formas de realizar tal tarefa é a apresentação de questões problemas pelo professor (TALÍZINA, 2000).

A segunda etapa, a apresentação da Base Orientadora, cumpre a função do descobrimento da atividade. Trata-se da fase de preparação para o processo ensino-aprendizagem, sua função é fundamentalmente diretiva das ações e operações que serão realizadas pelos estudantes. O processo ocorre de forma negociada com os estudantes, para que conheçam e construam uma representação do conteúdo da ação, do seu produto e do resultado. A construção dessa base orientadora proporciona a compreensão dos sentidos sociais e pessoais e dos significados relativos ao objeto da aprendizagem.

A assimilação de conceitos é a base da formação das ações mentais; esse processo formativo está determinado pelo caráter da parte orientadora da ação (TALÍZINA, 2000). Portanto, a BOA é um plano de ação futura, que proporciona direção e representação de uma tarefa, de forma antecipada. A BOA é responsável por prover uma espécie de sistema de condições concretas e indispensáveis para o cumprimento adequado de uma ação de ensino-aprendizagem.

A terceira etapa é a fase de execução das ações. Trata-se da atividade material ou materializada, quando diferentes materiais podem ser utilizados, como livros, experimentos de laboratório, cartões, fichas, quadros, materiais personalizados, etc. A diferença entre a forma material e a materializada é que, na primeira, o próprio objeto serve de objeto de estudo, enquanto que na forma materializada, o objeto está representado (figuras, esboços, etc). Assim, a forma materializada é indicada quando o objeto é inacessível, como por exemplo, no estudo da célula, quando não há laboratório disponível para observá-la.

$\mathrm{Na}$ quarta etapa, os estudantes resolvem as tarefas no plano verbal ou através da escrita, por exemplo, discutindo com o professor ou os colegas, ou então produzindo de textos. Talízina (2000) recomenda a utilização de situaçõesproblema como recursos para a assimilação de conceitos e/ou habilidades. 
Nessa etapa, a ação mental caracteriza-se por libertar-se da dependência dos objetos e da sua representação e passa para o plano da linguagem. O professor deve dar destaque à linguagem oral ou escrita. O estudante deve resolver as tarefas sem o apoio material. Tanto na quarta quanto na quinta etapa, recomendase que os estudantes trabalhem em duplas, em interação, trocando os papéis durante a interlocução.

Na última etapa, a formação do ato mental, o conceito já deve estar disponível ao sujeito. O estudante já é capaz de resolver problemas de forma independente, pois ocorreu a interiorização das ações e do conceito. Nessa última fase, a ação está automatizada e a fala é internalizada.

Como observamos, o processo de internalização acontece por meio de etapas mentais. Uma ação que, a princípio, é externa, é transformada em uma ação interna, ocorrendo uma mudança de ordem qualitativa. Assim, o estudante apropria-se das formas mais complexas de reflexão sobre os objetos do mundo exterior, que constituem a sua realidade, adquirindo a capacidade de tirar conclusões, a partir de suas próprias observações, de fazer deduções, conquistando as potencialidades do pensamento. 


\section{5 \\ A construção do percurso metodológico}

[...] O concreto é concreto porque é a síntese de múltiplas determinações, portanto, unidade da diversidade. Por essa razão, o concreto aparece no pensamento como processo da síntese, como resultado, não como ponto de partida, não obstante seja o ponto de partida efetivo e, em consequência, também o ponto de partida da intuição e da representação. (MARX, 2011, p. 77-78)

Neste capítulo, revelamos o trajeto metodológico da correlação dos dados coletados e das inferências. Está dividido em cinco itens: o primeiro trata da descrição dos instrumentos de coleta de dados; o segundo traz os perfis socioeconômicos dos estudantes, a formação acadêmica e a atividade profissional das professoras; o terceiro caracteriza o local onde foi realizada a pesquisa; o quarto expõe a sistematização dos dados; por fim, o quinto e último item traz as análises e inferências. Conforme os capítulos anteriores, sempre que possível, apresentamos análises e interpretações preliminares.

\section{1 Instrumentos utilizados na coleta de dados}

A princípio, utilizaríamos dois procedimentos para a coleta de dados, que seriam suficientes para levantar as informações para a análise. Os instrumentos escolhidos foram as entrevistas semiestruturadas (APÊNDICES $2 b$ e 3 ) e a observação participante.

No entanto, em contato com a realidade, concluímos que somente tais instrumentos seriam insuficientes para coletar as informações adequadas ao estudo proposto. Assim, optamos pelo uso de questionários, com os seguintes objetivos: levantar as condições socioeconômicas dos estudantes (APÊNDICE 4); adquirir informação sobre a formação acadêmica e as atividades profissionais das professoras (APÊNDICE 2a); obter os dados relativos à organização, estrutura física e funcionamento da instituição (APÊNDICE 1).

A preferência pelas entrevistas semiestruturadas foi devido à possibilidade de certa padronização das questões, estabelecidas em conformidade com a teoria que nos guiou e em consonância com os objetivos de pesquisa. A construção do 
roteiro das entrevistas teve a participação do Grupo de Pesquisa Desenvolvimento Humano e Educação - Grudhe da PUC-Rio ${ }^{75}$. Assim as categorias (códigos) elencadas a posteriori emergiram da correlação dos dados, principalmente das entrevistas, e dos recolhidos através dos outros instrumentos.

As falas dos entrevistados foram registradas em áudio, após a informação de que seriam gravadas. Antes de conceder as entrevistas, todos os participantes assinaram o Termo de Consentimento Livre e Esclarecido - TCLE. No caso dos adolescentes, o TCLE foi assinado pelo pai, mãe ou responsável direto. O estudante também deu a sua anuência, através do Termo de Assentimento.

As entrevistas com os estudantes ocorreram em uma sala cedida pela direção, num ambiente confortável e isolado, em clima de cordialidade. Convidamos quatro estudantes de cada turma, mas somente três compareceram à entrevista, no contraturno da aula. Em outro local, distante da sala da direção, em ambiente também confortável e isolado, entrevistamos cada uma das três professoras.

A fim de favorecer as análises, dividimos os dados em quantitativos e qualitativos, que posteriormente foram confrontados. Os dados quantitativos vieram com a aplicação de questionários estruturados. Coletamos os dados relativos à estrutura física, organização e funcionamento da instituição em documentos institucionais e nos diálogos estabelecidos com a diretora geral e adjunta, os coordenadores do ensino médio e técnicos da secretaria. Esses dados foram sistematizados e organizados no formato de relatórios.

Obtivemos as informações relativas às condições socioeconômicas dos estudantes por meio de questionário estruturado, aplicado a todos os estudantes das turmas T1, T2 e T3, assim como as informações referentes à formação profissional e acadêmica das professoras.

Recolhemos os dados de ordem qualitativa através da observação direta e das entrevistas com três professoras e um grupo de nove estudantes. Selecionamos os estudantes conforme o critério de destaque no grupo, empatia com o pesquisador e com a pesquisa, revelados através da observação.

Segundo Minayo (2002, p. 59), a observação participante configura-se pelo "contato direto do pesquisador com o fenômeno observado, com o objetivo

\footnotetext{
${ }^{75}$ O grupo existe desde o ano de 2009, sendo coordenado pela Prof. ${ }^{a}$ Dr. ${ }^{a}$ Zena Eiseberg, do Departamento de Educação da PUC-Rio.
} 
de obter informações sobre os atores sociais em seus próprios contextos". Acompanhamos cerca de 20 aulas ministradas pelas três professoras, num total de 60 aulas, durante o semestre letivo. O período relativo à observação foi de fevereiro a junho de 2017, compreendendo dois bimestres.

Registramos os dados coletados diariamente, em um caderno de campo utilizado para descrever a aula, focalizando principalmente: a atmosfera da turma; a interação professor-estudante, a interação estudante-estudante; e a atividade de ensino-aprendizagem. Observamos e analisamos diversas sucessões ou sequências de ensino. Por uma sequência ensino, compreende-se uma relação de conteúdos que possui uma organização sistemática, constituindo uma unidade integrada. Por exemplo, o estudo da célula corresponde a uma unidade e o estudo da membrana e das organelas celulares são partes da unidade. Nesse caso, uma sequência de ensino é formada por várias unidades didáticas.

Utilizamos o conceito "unidade didática", no sentido atribuído por Libâneo (1990, p. 232): "um conjunto estruturado de atividades de ensino e aprendizagem, numa sequência lógica, visando à consecução de determinados objetivos de aprendizagem". Essas unidades ou sequências foram baseadas no livro didático, distribuído na escola e disponibilizado aos estudantes.

A observação levou-nos à coleta de dados sobre situações comportamentais e atitudes dos estudantes e das professoras, assim como respostas para as questões constantes nos roteiros das entrevistas e nos questionários. Estamos cientes de suas limitações, e concordamos com Lakatos e Marconi (2003, p. 191), que chamam a atenção para os pontos fortes e fracos do instrumento.

Como principais pontos positivos, destacamos: a versatilidade e a flexibilidade, uma vez que adentramos na subjetividade do entrevistado, com o consequente esclarecimento sobre o seu posicionamento frente às questões levantadas. Por se tratar da percepção do indivíduo, aclaramos pontos de vista e significados não captados por outros instrumentos.

Como pontos negativos: a falta de motivação do entrevistado em responder às perguntas; a inadequada compreensão dos significados das perguntas; o fornecimento de respostas nem sempre verdadeiras; a inabilidade ou incapacidade do entrevistado em responder adequadamente às questões, em decorrência de insuficiência vocabular ou problemas psicológicos; a influência exercida pelo 
aspecto pessoal do entrevistador; a influência das concepções do entrevistador sobre as respostas do entrevistado; e a inexistência de um local adequado para obter os dados advindos da entrevista. Na sequência do trabalho, realizamos uma primeira organização dos dados coletados, conforme descrição a seguir.

\section{2}

Perfis dos grupos examinados: estudantes e professoras

\section{Estudantes}

Levantamos o perfil dos estudantes a partir dos dados obtidos com o questionário específico (APÊNDICE 5). No momento do estudo, a escola contava com 20 turmas de ensino médio, perfazendo um total de cerca de 900 estudantes, distribuídos em dois turnos, matutino e noturno. O maior número de alunos se concentrava no período matutino. As turmas estavam assim distribuídas (TABELA 2):

Tabela 2 - Distribuição das turmas por período.

\begin{tabular}{ccc}
\hline \multirow{2}{*}{ SÉRIES } & \multicolumn{2}{c}{$\mathbf{N}^{\mathbf{0}}$ DE TURMAS/TURNO } \\
\cline { 2 - 3 } $1^{\mathrm{a}}$ & MATUTINO & NOTURNO \\
$2^{\mathrm{a}}$ & 6 & 2 \\
$3^{\mathrm{a}}$ & 5 & 1 \\
TOTAIS & 5 & 1 \\
\hline
\end{tabular}

Fonte: Elaborada pelo autor.

Como vemos na tabela 2 , o ensino médio matutino estava organizado em 16 turmas. Naquele momento, o número médio de matriculados nas turmas era de 45 estudantes. Optamos pela primeira série por dois motivos: primeiro, por ser o início de um importante ciclo da educação básica, com características muito especiais; segundo, porque a maioria dos estudantes se encontrava no período da adolescência, quando os conceitos verdadeiros são desenvolvidos.

Acompanhamos três das seis turmas de primeiro ano (A, B, C, D, E, F), que aqui designaremos de "T1" (A), “T2" (D) e "T3" (F). A seleção da amostra deu-se em decorrência, principalmente, da distribuição das aulas, pois 
conseguimos acompanhar regularmente todas as aulas das professoras, sem choque de horários.

Em conversa informal, o coordenador expôs que a turma "T1" era formada por estudantes 'não repetentes', em sua maioria alunos novos na escola e que nas demais turmas havia um número maior de 'repetentes'. Os dados revelaram que a turma “T3", realmente, concentrava o maior número de estudantes reprovados, apresentando uma maior distorção idade/série (FIGURA 2). Em relação à distribuição das faixas etárias, as três turmas assim se apresentavam:

Figura 2 - Gráfico mostra a distribuição das faixas etárias por turma.

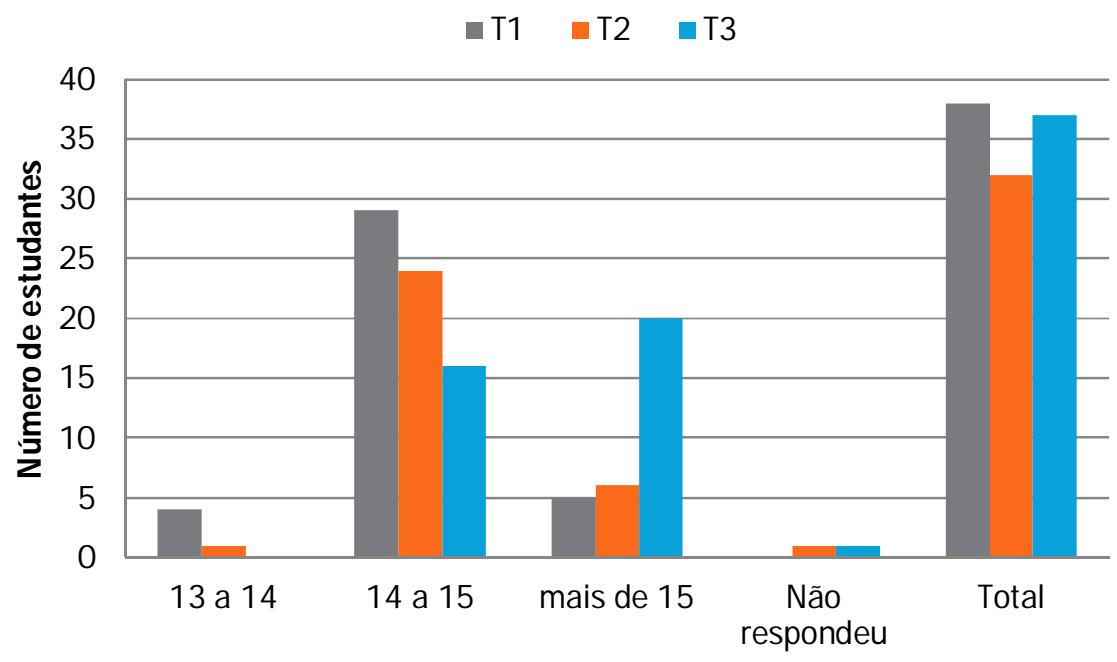

Fonte: Elaborado pelo autor.

Observamos, na figura 3, que a T3 inseria o maior número de alunos acima de 15 anos, o que correspondia a mais da metade da turma. Segundo demonstraremos, a $\mathbf{T 3}$ foi a turma com o maior número de alunos repetentes. Esta turma estava sob responsabilidade da professora com o maior tempo de experiência no magistério, principalmente no ensino fundamental, porém atuando havia um ano na escola. Essa professora também trabalhava no ensino fundamental, na mesma escola, no período vespertino.

Chamou-nos a atenção o número de estudantes 'casados' e já 'separados'. O dado foi evidenciado em T1 e T3, conforme demonstrado a seguir (TABELA 3): 
Tabela 3 - Estudantes afirmaram que já foram ou se encontram casados.

\begin{tabular}{lcccc}
\hline \multicolumn{1}{c}{ ESTADO CIVIL } & T1 & T2 & T3 & \% \\
\hline Solteiro & 35 & 31 & 33 & 92,5 \\
Casado & 1 & 1 & 2 & 3,7 \\
Separado & 2 & 0 & 1 & 2,9 \\
Não respondeu & 0 & 0 & 1 & 0,9 \\
Total & $\mathbf{3 8}$ & $\mathbf{3 2}$ & $\mathbf{3 7}$ & 100 \\
\hline
\end{tabular}

Fonte: Elaborado pelo autor.

Uma das questões do questionário foi sobre a existência de computador nas casas dos estudantes. As respostas foram as seguintes:

Figura 3 - Gráfico mostra o número de alunos que possuem computador em casa.

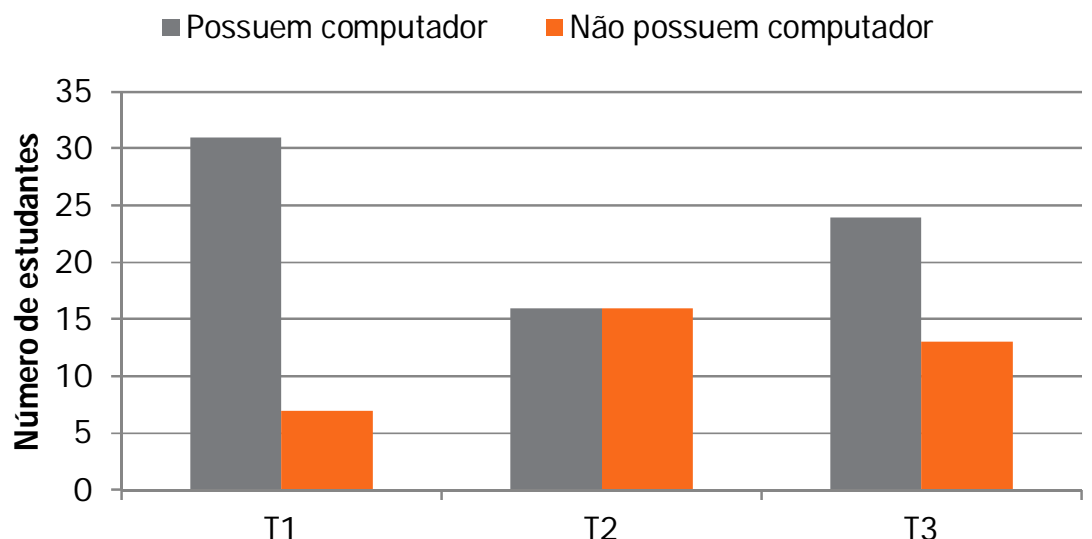

Fonte: Elaborado pelo autor.

Esses dados (FIGURA 3) estão condizentes com as informações do PNAD/IBGE $2016^{76}$, que aponta que o computador está presente nas casas brasileiras em cerca de $50 \%$ dos lares.

A informação que obtivemos é que a escola não disponibilizava os computadores da sala de informática para uso dos estudantes. $\mathrm{O}$ acesso a esta sala somente se dava com a presença de um professor e no momento da atividade. No entanto, no período de observação, em nenhum momento as professoras utilizaram a sala de informática.

\footnotetext{
${ }^{76}$ Cf. <https://biblioteca.ibge.gov.br/visualizacao/livros/liv98887.pdf>
} 
Outra questão que entendemos importante para traçar o perfil dos estudantes, foi o acesso à internet a partir de suas casas. Quando perguntado aos estudantes se eles tinham acesso à internet em suas casas a resposta foi a seguinte:

Tabela 4 - Acesso à internet em suas residências.

\begin{tabular}{cccccc}
\hline RESPOSTA & T1 & T2 & T3 & TOTAIS & $\%$ \\
\hline SIM & 36 & 24 & 29 & 89 & 83,1 \\
NÃO & 2 & 8 & 8 & 18 & 16,9 \\
TOTAL & 38 & 32 & 37 & 107 & 100 \\
\hline \multicolumn{5}{c}{ Fonte: Elaborado pelo autor. }
\end{tabular}

Fonte: Elaborado pelo autor.

Podemos analisar esses dados (TABELA 4) comparando com os anteriores. Muito embora a quantidade de estudantes que afirmou não ter computador em casa seja elevada, eles devem acessar a internet possivelmente de aparelhos celulares ou tablets. Ainda assim, cerca de 20 alunos, do total das turmas, não têm acesso à internet em suas casas e muito menos na escola, uma vez que a instituição também não disponibiliza acesso via internet sem fio (Wi-Fi).

A pesquisa indicou que, apenas 10 estudantes não possuem aparelho celular. Esses dados evidenciam que, não são todos os alunos que tem acesso a internet, o que indica uma importante lacuna na formação dos estudantes, pois o acesso a internet, neste momento, é indispensável a pesquisa, comunicação e a diversão. No momento da pesquisa a escola não havia biblioteca.

Quando perguntados sobre reprovação no ensino médio, a resposta apresentada por eles foi:

Tabela 5 - Alunos que já foram reprovados no Ensino Médio.

\begin{tabular}{ccccc}
\hline & SIM & \% & NÃO & \% \\
\hline T1 & 2 & 5,5 & 36 & 94,5 \\
T2 & 4 & 14,2 & 28 & 85,8 \\
T3 & 6 & 19,3 & 31 & 80,7 \\
\hline
\end{tabular}

Fonte: Elaborado pelo autor.

Os dados da tabela 5 confirmam a informação dos orientadores educacionais: à medida que as turmas avançam de "A" para "F", o número de 
estudantes repetentes aumenta. Acreditamos que o número pode ser maior do que aquele que apareceu no questionário, pois nos pareceu que os estudantes tinham certo receio de expor essa informação.

Quando perguntados se trabalham, já trabalharam ou nunca trabalharam, obtivemos os seguintes resultados:

Figura 4 - Gráfico indica número de alunos que trabalham, já trabalharam ou que ainda não trabalham.

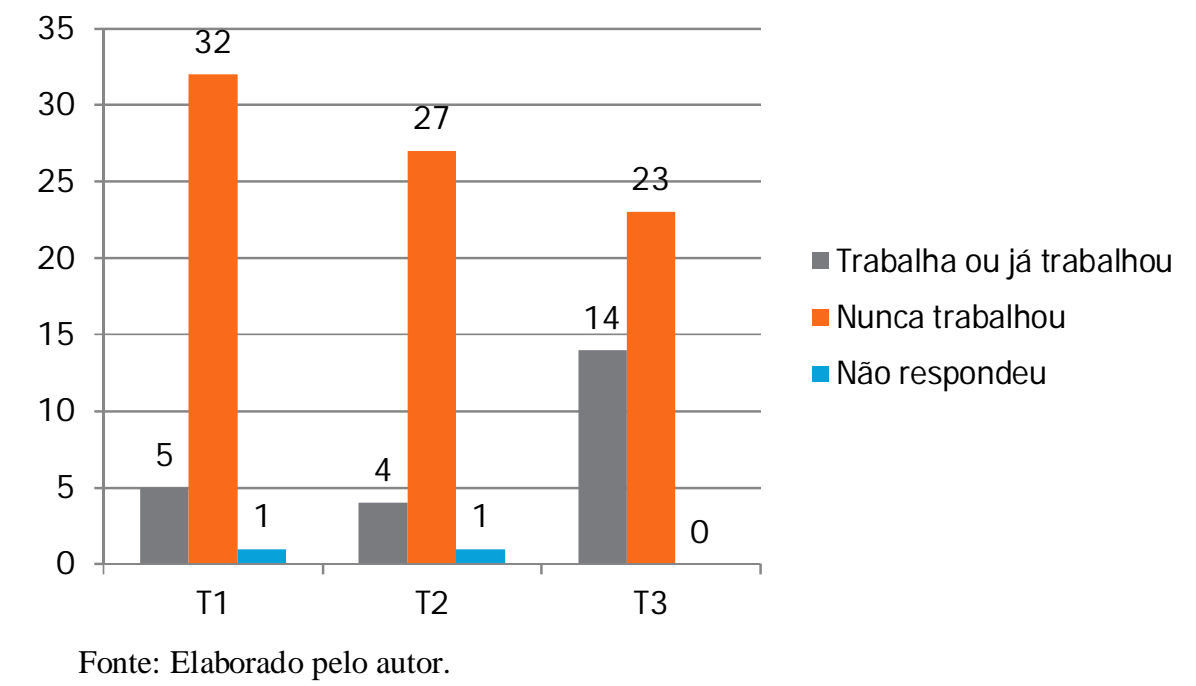

Na figura 4 constatamos que a T3 corresponde ao grupo com o número maior de estudantes que afirmaram ter trabalhado ou que ainda trabalham. Importante lembrar que a $\mathbf{T 3}$ foi a turma com a maior distorção idade/série (FIGURA 2). Nessa turma, cerca de $20 \%$ dos estudantes tinham idade superior a 15 anos. Os dados do perfil de renda (FIGURA 5) demonstram que os estudantes pertencem às classes mais pobres. Quando perguntados sobre o perfil de renda, responderam: 
Figura 5 - Gráfico mostra a distribuição de renda das famílias dos estudantes.

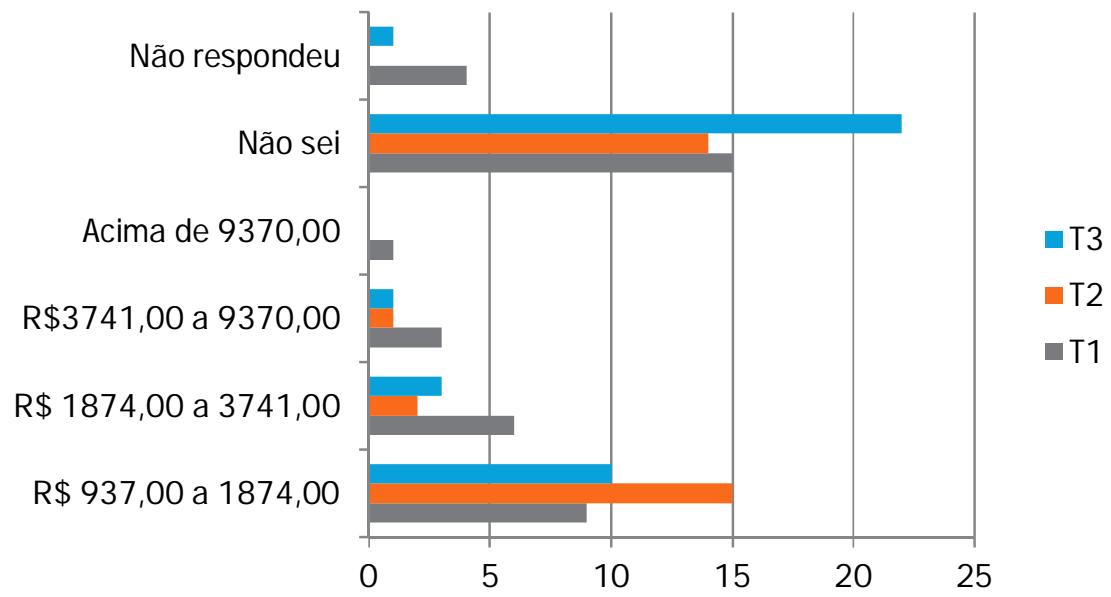

Fonte: Elaborado pelo autor.

Os dados expressos na figura 5 corroboram com a afirmação de que os estudantes das três turmas fazem parte da classe trabalhadora. Mesmo que haja um número grande de estudantes que não saibam o rendimento da família, os dados indicam uma tendência para a faixa da população mais pobre.

Para encerrar a análise socioeconômica, quando indagados sobre o número de pessoas que viviam na casa, estas foram as respostas:

Tabela 6 - Pessoas que dividem a casa com o estudante.

\begin{tabular}{lccccc}
\hline $\begin{array}{l}\text { NÚMERO DE PESSOAS QUE } \\
\text { MORAM COM O/A ESTUDANTE }\end{array}$ & T1 & T2 & T3 & TOTAL & \% \\
\hline Moro sozinho & 0 & 0 & 0 & 0 & 0 \\
1 a 3 pessoas & 24 & 11 & 11 & 46 & 42,9 \\
4 a 7 pessoas & 13 & 16 & 20 & 49 & 45,8 \\
8 a 10 pessoas & 1 & 5 & 2 & 8 & 7,6 \\
Mais 10 pessoas & 0 & 0 & 1 & 1 & 0,9 \\
Não respondeu & 0 & 0 & 3 & 3 & 2,8 \\
TOTAIS & $\mathbf{3 8}$ & $\mathbf{3 2}$ & $\mathbf{3 7}$ & $\mathbf{1 0 7}$ & $\mathbf{1 0 0}$ \\
\hline
\end{tabular}

Fonte: Elaborado pelo autor.

Pela tabela 6, verificamos que mais da metade $54,3 \%$ dos estudantes vivem em famílias bastante numerosas, com quatro ou dez componentes. Entendemos que o tamanho da família seja um fator demográfico significativo, pois interfere na escolarização, uma vez que há uma diluição dos recursos disponíveis para esse fim. 
Conforme Andrade (2008, p. 9), a diluição dos recursos parentais em razão do maior número de filhos mostra-se mais patente em termos materiais do que psíquicos (tempo e energia). Ainda conforme o autor, essa constatação talvez possa ser atribuída ao fato de que a repartição do tempo e da atenção parentais não seja tão perceptível quanto a divisão dos bens materiais, de tal maneira que só se fez sentir mais fortemente nas famílias entrevistadas com quatro ou mais filhos.

Segundo dados do IBGE $(2016)^{77}$, do Sistema de Indicadores Sociais (SIS), no Brasil havia 25,4\% da população em situação de pobreza, conforme critério adotado pelo Banco Mundial (renda de US\$5,5 p/dia). Na região centrooeste, a proporção é de $17 \%$ da população, ocupando o terceiro lugar depois das regiões nordeste e norte. Ao proceder à correlação entre os dados apresentados, temos que os estudantes das três turmas analisadas são oriundos das classes trabalhadoras.

Esses dados compõem o arcabouço de nossa investigação. Entendemos ser justa a relação entre a pobreza e o acesso à educação e à cultura. E assim, devido à dualidade persistente nesta etapa, a maior parte dos estudantes das classes média e superior frequentam as escolas privadas.

Apoiado em Arroyo (2014), é preciso reconhecer a existência da pobreza, para que ela ganhe alguma concretude. Nas próprias palavras do autor:

[...] reconhecer a pobreza e as desigualdades, fundamentalmente, significa levar em conta que a existência persistente dos pobres nas escolas brasileiras traz reflexões importantes para as práticas pedagógicas e para a gestão educacional. Assim, é necessário não apenas saber que as escolas estão repletas de meninos e meninas pobres, mas, muito mais do que isso, é preciso também questionar quais exigências essas vivências da pobreza, da precariedade material extrema, demandam de nossas práticas. (ARROYO, 2014, p. 7)

A pobreza tem repercussões sobre a igualdade de acesso à cultura material. Não se trata de inferioridade moral, cultural ou civilizatória, mas as privações materiais impossibilitam ou limitam uma vida digna e justa a essas pessoas. É consequência de uma sociedade desigual, dividida em classes.

\footnotetext{
77 Cf. https://agenciadenoticias.ibge.gov.br/agencia-noticias/2012-agencia-denoticias/noticias/18825-um-quarto-da-populacao-vive-com-menos-de-r-387-por-mes
} 


\section{Professoras}

Os dados relativos ao perfil profissional e acadêmico das professoras foram elaborados através de questionário próprio (APÊNDICE 2). Segundo já informado, cada uma das turmas tinha uma professora específica de biologia. Todas eram mulheres, com formação superior na área de atuação, com licenciatura em ciências biológicas. Os dados referentes à formação das professoras e as suas experiências profissionais (organizados no quadro 1) corroboraram com as nossas inferências.

Quadro 1 - Formação acadêmica e atividade profissional das professoras.

\begin{tabular}{|l|r|r|r|}
\hline Dados pessoais & \multicolumn{1}{|c|}{ P1 } & \multicolumn{1}{|c|}{ P2 } \\
\hline Curso superior/conclusão & Biologia & Biologia & Biologia \\
\hline Tipo de instituição ensino superior & Privada & Pública & Pública \\
\hline Pós-graduação latu sensu & Possui & Não possui & Não possui \\
\hline Tipo de vínculo empregatício & $\begin{array}{r}\text { Concurso/ } \\
\text { contrato }\end{array}$ & Contrato & $\begin{array}{r}\text { Concurso/ } \\
\text { contrato }\end{array}$ \\
\hline Tempo de magistério & 4 anos & 7 anos & 10 anos \\
\hline Tempo serviço na escola & 2 anos & 8 meses & 1 ano \\
\hline $\begin{array}{l}\text { Carga horária de biologia no ensino } \\
\text { médio }\end{array}$ & 20 h/a & $15 \mathrm{~h} / \mathrm{a}$ & $18 \mathrm{~h} / \mathrm{a}$ \\
\hline $\begin{array}{l}\text { Carga horária de outra } \\
\text { disciplina no ensino médio }\end{array}$ & - & 6 & ------ \\
\hline Quantidade de turmas ensino médio & 7 & 5 & 6 \\
\hline $\begin{array}{l}\text { Número de estudantes por } \\
\text { turma (média) }\end{array}$ & 40 & 42 & 42 \\
\hline $\begin{array}{l}\text { Carga horária no ensino } \\
\text { fundamental }\end{array}$ & $20 \mathrm{~h} / \mathrm{a}$ & - & $20 \mathrm{~h} / \mathrm{a}$ \\
\hline Número de escolas em que trabalha & 1 & 2 & 2 \\
\hline Atuação no ensino fundamental & Sim & Não & Sim \\
\hline Disciplina no ensino fundamental & Ciências & ----- & Ciências \\
\hline Exerce atividade além da docência & Não & Não & Não \\
\hline
\end{tabular}

Fonte: Elaborado pelo autor.

O quadro exibe os dados referentes às diferenças de formação acadêmica e atividade profissional das professoras. Embora ele seja autoexplicativo, destacamos alguns aspectos relevantes para a pesquisa. Por exemplo, P1 é a única das professoras que possuía pós-graduação (latu sensu) na sua área de formação e tinha o maior tempo de serviço na escola. Antes de ser professora, P1 atuou como técnica de laboratório na universidade onde se formou. 
Também percebemos que P2 trabalha em regime precário, uma vez que tem contrato por tempo determinado com o governo do estado. Naquele momento, ela estava substituindo um professor de biologia, afastado por licença médica. Além disso, ministrava aula de outra disciplina para a T2 que não era de sua área específica.

No momento da pesquisa, tanto $\mathbf{P 1}$ quanto $\mathbf{P 3}$ trabalhavam em dois turnos de aula. Ambas atuavam também no ensino fundamental. Ainda destacamos o maior tempo de experiência no magistério de P3. Chamamos a atenção para a precarização do trabalho docente, através do número elevado de turmas atribuídas a cada uma das professoras: P1 e P3 tinham 280 e 240 estudantes, respectivamente, sob os seus cuidados.

\section{3 \\ Descrição e delimitação do local da pesquisa: cidade e a escola}

O estudo ocorreu em uma escola pública estadual localizada no município de Corumbá, região oeste do estado, às margens do Rio Paraguai, na fronteira Brasil-Bolívia. A cidade e a escola possuem diversas especificidades e, por esse motivo, decidimos descrevê-las brevemente.

Corumbá é uma das cidades mais antigas do Brasil, fundada em 1778 como um porto militar (PEREIRA, 2007, p. 40). No ano de 1853, o porto foi habilitado ao comércio e, devido à sua localização geográfica, tornou-se um importante centro econômico, ligando a Europa ao Brasil, desenvolvendo um intenso comércio, principalmente de couro, erva-mate, cal e charques.

Com o advento da primeira guerra mundial e a construção da ferrovia, ligando Itapura, no estado de São Paulo, a Corumbá, no então estado do Mato Grosso, hoje Mato Grosso do Sul, inaugurada em 1918, o transporte fluvial foi perdendo espaço e a cidade entrou em decadência. Sob o ponto de vista econômico, a pecuária tem um maior peso, seguido pela extração do ferro e pelo ecoturismo (PEREIRA, 2007) ${ }^{78}$. A cidade boliviana de Puerto Quijarro está localizada a apenas cinco quilômetros de Corumbá. Como se trata de uma 'fronteira seca', a passagem de um país ao outro ocorre com certa facilidade, pois

\footnotetext{
${ }^{78}$ Ibid, p. 101.
} 
o trânsito é livre na maior parte do tempo (PEREIRA, 2007) ${ }^{79}$. Essa proximidade com a Bolívia produziu uma intensa relação econômica e cultural, contribuindo para a formação identitária.

Conforme dados do IBGE (2017), a cidade contava com cerca de cem mil habitantes $^{80}$, sendo considerada a quarta maior cidade do estado, em número de habitantes e um dos maiores municípios do Brasil em termos territoriais. Ressaltamos que, devido à proximidade com a fronteira Brasil/Bolívia, a cidade tem uma população diária flutuante. Muitos cidadãos bolivianos, que vivem na cidade boliviana de Puerto Quijaro, desenvolvem atividades econômicas na cidade de Corumbá, a exemplo das várias feiras livres.

Os bolivianos também utilizam os diversos serviços oferecidos no Brasil, como os de saúde, até mesmo o de educação. Inclusive muitas escolas públicas recebem estudantes provenientes do lado boliviano, a exemplo da escola escolhida para o desenvolvimento e realização desse estudo.

No momento da pesquisa, a cidade de Corumbá contava com 18 escolas de ensino médio, sendo 11 públicas (10 estaduais e 1 federal ${ }^{81}$ ) e sete privadas, com 304 professores (BRASIL - INEP - 2015). Nesse mesmo período, havia 3.758 estudantes matriculados no ensino médio, sendo assim distribuídos: $2.889 \mathrm{em}$ escolas estaduais; 242 na escola federal; e 627 em instituições privadas.

Um dado considerado relevante é que, apesar do aumento da população, o número de estudantes matriculados no ensino médio no município sofreu um decréscimo $^{82}$ no período de 2005 a 2015, conforme observamos a seguir (TABELA 7):

\footnotetext{
${ }^{79}$ Ibid, 87.

${ }^{80}$ Conforme dados do IBGE de 2017, a população da cidade de Corumbá é estimada em 109.899 habitantes.

${ }^{81}$ Trata-se de um dos dez campi do Instituto Federal de Mato Grosso do Sul - IFMS, distribuídos pelo estado.

${ }_{82}$ Esse decréscimo vem confirmar os dados oficiais obtidos pelo Censo da educação, que mostra um decréscimo nas matrículas no ensino médio nos últimos dez anos.
} 
Tabela 7 - Involução do número de estudantes matriculados no ensino médio no período de dez anos em Corumbá MS.

\begin{tabular}{ccc}
\hline ANO & $\begin{array}{c}\text { NÚMERO DE } \\
\text { MATRÍCULAS }\end{array}$ & $\begin{array}{c}\text { QUEDA DE } \\
\text { MATRÍCULAS \% }\end{array}$ \\
\hline 2005 & 4110 & Valor de referência \\
2007 & 3547 & 13,7 \\
2009 & 3401 & 17,2 \\
2012 & 4099 & 0,3 \\
2015 & 3758 & 8,5 \\
\hline
\end{tabular}

Fonte: Ministério da educação, Instituto Nacional de Pesquisas Educacionais - INEP. Censo Educacional, 2015. Os dados incluem estudantes matriculados em escolas públicas e privadas.

Nos dados da tabela 7 , verificamos uma diminuição no número de estudantes matriculados no ensino médio no período considerado. Os valores apontam para uma perda de 10\%, em média, de estudantes matriculados. Os dados corroboram com os números nacionais, que também evidenciaram um decréscimo nas matrículas no ensino médio. No caso de Corumbá, uma explicação plausível é que há um grupamento da Marinha e do Exército, existindo um fluxo constante de famílias que residem na cidade por algum tempo e depois são transferidas a outras localidades.

A escola onde a pesquisa foi realizada faz parte de um projeto social desenvolvido e mantido por uma congregação ligada à igreja católica. O projeto social surgiu com o objetivo de atender a uma clientela formada, sobretudo, pelos filhos de trabalhadores que, naquele momento, residiam na periferia da cidade, oferecendo cursos de formação técnica. O projeto existe ainda hoje e continua a oferecer formação profissional para os filhos das classes mais populares. A estrutura física da escola funciona independentemente do projeto social, muito embora estejam no mesmo terreno.

$\mathrm{Na}$ ocasião da investigação, a escola contava com aproximadamente 1.994 $^{83}$ estudantes matriculados, sendo assim distribuídos: 1.127 no Ensino Fundamental II ( $4^{\circ}$ ao $9^{\circ}$ ano) e $\mathbf{8 6 7}$ no ensino médio. A escola funcionava em três turnos: matutino, vespertino e noturno. $\mathrm{O}$ ensino médio era oferecido em dois

\footnotetext{
${ }^{83}$ No momento da pesquisa, a secretária da escola nos informou que muitos estudantes já haviam sido transferidos ou solicitaram o cancelamento da matrícula, principalmente os estudantes que cursavam o ensino médio no período noturno. A evasão é considerável nesse nível de ensino, especialmente no período noturno.
} 
períodos, o matutino e o noturno. A escola contava com 86 professores, que atendiam a todos os níveis (Fundamental II e Ensino Médio). Um dado que chama a atenção é que a escola era, naquele momento, considerada a maior instituição do estado em número de estudantes. Esse foi um dos motivos para a sua escolha para a nossa pesquisa. A quantidade de turmas existentes e o número de professoras favoreceu a concentração do trabalho em uma única escola.

Em termos físicos, trata-se de uma escola de grande porte, ocupando quase que a totalidade de uma quadra. Na entrada principal da escola, há um corredor coberto, com cerca de 50 metros, que leva ao prédio principal. Antes do prédio principal, ao lado desse corredor, há uma construção onde fica a sala das diretoras e uma sala de reuniões contígua. De frente à sala da diretoria, está a secretaria da escola. No final do corredor, do lado direito, há uma quadra poliesportiva com cobertura.

Seguindo pelo corredor, defrontamo-nos com um prédio grande em formato de "L", com dois pisos: superior e inferior. Nesse prédio, funciona a maior parte do ensino médio e o fundamental. As salas de aula estão dispostas em um dos lados do prédio, e do outro, se encontra um longo e amplo corredor. A disposição das salas de aula é a mesma nos dois pisos.

$\mathrm{Na}$ parte inferior, na região central do prédio, encontram-se duas grandes escadas que dão acesso ao piso superior. As salas de aula do prédio principal são semelhantes em tamanho e disposição: são amplas, com seis janelas grandes, sendo três voltadas para o corredor e três voltadas para a parte externa. Somente uma porta dá acesso à sala de aula.

Em cada sala existe um tablado, onde fica uma mesa para o professor, disposta em nível mais elevado em relação aos estudantes. As salas não são climatizadas, possuindo apenas quatro grandes ventiladores de teto. Os estudantes contam com mesinhas individuais. Não existe nenhum outro móvel na sala. As salas utilizadas pelas turmas T2 e T3 localizavam-se nessa parte térrea. Somente a T1 se encontrava no piso superior.

No pavimento inferior, além das salas de aula, na parte menor do "L", fica a sala de professores. Trata-se de uma sala comprida, com uma mesa longa no centro, rodeada de cadeiras e diversos armários nas paredes laterais. Há dois banheiros, separados por sexo. Na sala também há dois computadores ligados à internet, para uso exclusivo dos professores. Próximo à sala de professores, 
encontra-se uma pequena sala utilizada pelos dois coordenadores do ensino médio.

De um dos lados da sala dos professores, uma sala comprida é utilizada como laboratório de informática e, nela havia vinte computadores ligados à internet. Essa mesma sala também guarda os aparelhos de multimídia (projetor), que funcionam como lousas digitais. Mas como a escola não possui estrutura, eles não são utilizados para esse fim. Os professores fazem a reserva da sala com um técnico, nessa mesma sala.

Ainda no piso inferior, uma cantina funciona de forma terceirizada, comercializando refrigerantes, guloseimas e salgados. Além da cantina, a escola possui um espaço, contíguo ao prédio principal, utilizado como refeitório pelos estudantes. $\mathrm{O}$ espaço conta com uma cozinha e mesas para uso dos estudantes. No período da atividade de campo, era servido aos estudantes um lanche durante o intervalo do recreio.

No pavimento superior, na parte maior do "L", as salas de aula são idênticas às localizadas na parte inferior do prédio. No final do corredor, uma sala ampla é usada como anfiteatro, com capacidade para cerca de 200 pessoas. O anfiteatro possuía climatização própria. Também há diversas pequenas salas, destinadas ao que chamam de pastoral. ${ }^{84}$

Por fim, há ainda duas outras construções anexas ao prédio principal, localizadas no térreo, usadas como salas de aula. Além da quadra coberta, existem três quadras poliesportivas, sem cobertura, em frente ao prédio principal. A seguir, mostramos o croqui da área da construção, para melhor visualização (FIGURA 6).

\footnotetext{
${ }^{84} \mathrm{Na}$ escola, a pastoral é uma estrutura formada por agentes da igreja católica, os auxiliares, e os estudantes. Tem a função de evangelização, de promover a catequese e organizar as cerimônias religiosas e outros eventos.
} 
Figura 6 - Croqui da escola.

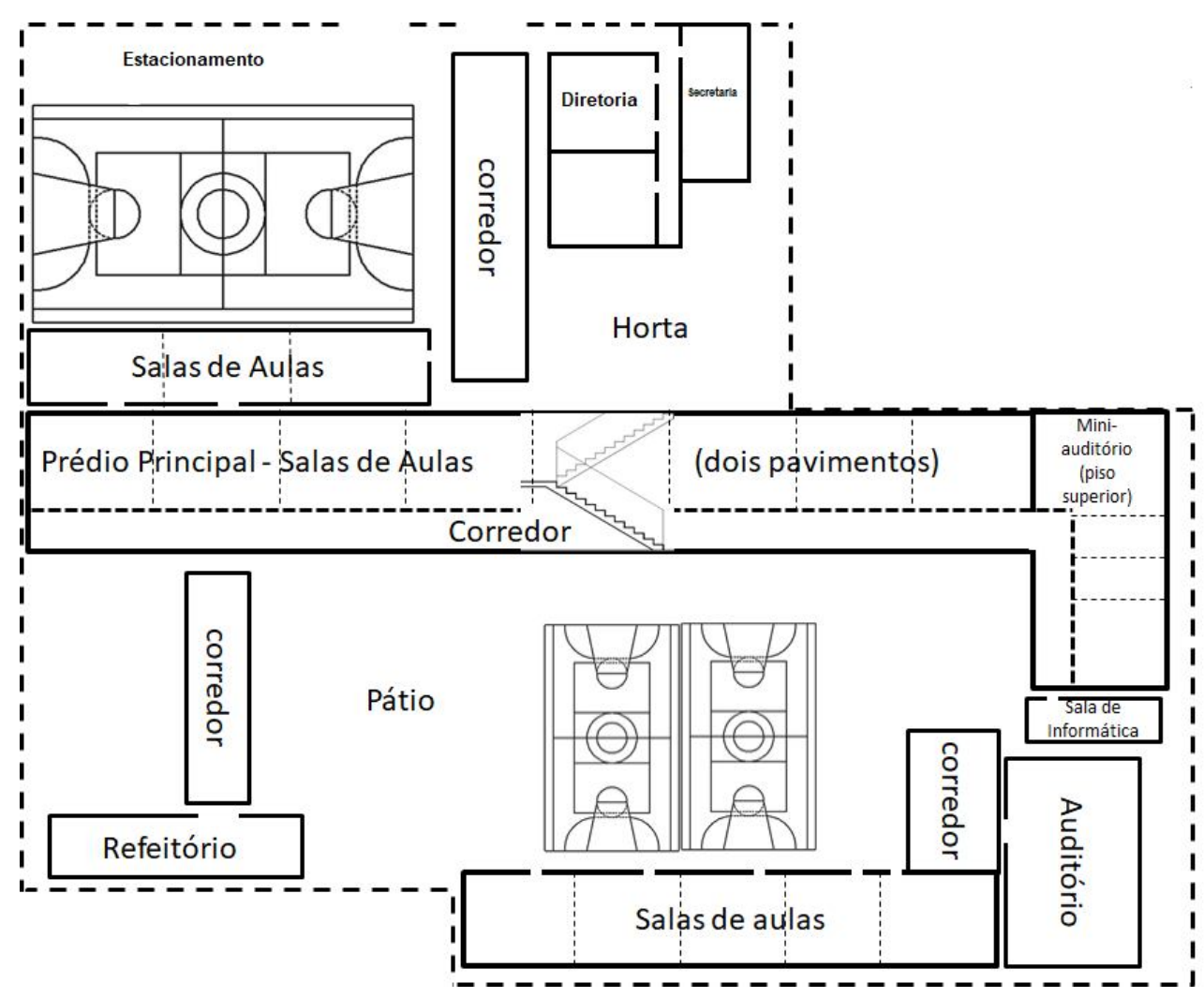

Fonte: Produzida pelo autor

Sob nosso ponto de vista, em termos de estrutura física, a escola detém as condições adequadas para as atividades pedagógicas, apesar da precariedade na manutenção.

\section{4}

\section{Sistematização dos dados através do ATLAS Ti}

Organizamos os dados quantitativos em resumos, que posteriormente deram origem às tabelas e gráficos, para melhor visualização e interpretação, conforme o item 5.2. A etapa seguinte foi de transcrição integral dos arquivos de áudios das entrevistas, com o apoio de um software reprodutor de áudio, o Express Scribe Transcription Software ${ }^{85}$. Ao transcrevermos as entrevistas,

\footnotetext{
${ }^{85}$ Consiste em um programa cuja função básica é controlar a reprodução de áudio, usando um pedal de transcrição ou teclado. O software oferece diversos recursos, incluindo a reprodução em velocidade variável e o gerenciamento de arquivos de texto, entre outros. A versão gratuita suporta formatos de áudio comuns, incluindo wav, mp3, wma e dct. Pode ser obtido através do link<http://www.nch.com.au/scribe/essetup.exe>
} 
também demos início à análise dos dados, com a construção das categorias ou códigos que foram posteriormente sistematizadas com o programa ATLAS.Ti ${ }^{86}$.

O programa usado para a transcrição não transcreveu automaticamente os áudios, mas serviu de apoio ao processo, pois proporciona melhor controle da reprodução do som, facilitando o trabalho de digitação das falas. A vantagem do software é que a transcrição pode ocorrer simultaneamente com a digitação, não necessitando usar dois programas.

A fim de manter um padrão e a fidedignidade no processo de transcrição das falas dos participantes, arranjamos os dados conforme o método concebido por Marcushi ${ }^{87}$ (1986, p. 10). Procuramos seguir os sinais propostos pelo autor, tendo em mente algumas de suas orientações: 1) evitar as maiúsculas em início de turno; 2) adotar uma sequência com linhas não muito longas, para melhorar a visualização do conjunto; 3 ) indicar os falantes com siglas ou letras do nome ou alfabeto; e 4) não cortar palavras na passagem de uma linha para outra.

Depois que os áudios foram transcritos, foram transferidos para outro software, o ATLAS.Ti, uma importante ferramenta de análise de dados. Inserimos os dados das entrevistas no programa como documentos primários. O programa levou à criação de famílias de documentos primários (entrevistas, relatório de observações, questionário socioeconômico) e as correlações deram origem às famílias de códigos (categorias) e os códigos (subcategorias).

O software ATLAS.Ti não faz a análise do conteúdo. Sua função é organizar os dados, mas as categorias são definidas pelo próprio pesquisador. Uma das funções que mais utilizamos foi a construção das chamadas redes semânticas entre as categorias e subcategorias. É responsabilidade do pesquisador fazer as inferências possíveis e necessárias para a compreensão do fenômeno.

As redes semânticas são semelhantes a mapas conceituais, ou seja, são redes de vínculos entre conceitos e/ou ideias. Elas são construídas automaticamente pelo programa e baseiam-se nas inter-relações entre as categorias e as subcategorias. Além do arquivo gráfico com as suas redes de vínculos, o programa também apresenta a densidade com que os códigos estão

${ }^{86}$ O ATLAS.Ti é um programa de análise de dados qualitativos, que possui um conjunto de ferramentas que permite ao pesquisador uma melhor organização e disposição dos dados de pesquisa, desse modo facilitando suas análises. A versão utilizada do software foi a 7.5.18. Produzido pela Ciscom System, inc. @1993-2017 por ATLAS.Ti, Berlin.

${ }^{87} \mathrm{O}$ método foi criado por Marcuschi (1986), que compilou 14 sinais que ele considerava mais frequentes e úteis para realizar uma transcrição. 
relacionados, o que nos foi útil para determinar a consistência dos vínculos entre os códigos.

A rede semântica forneceu a primeira forma de organizar os dados, chegando a alguns resultados e inferências. Além dessa ferramenta, o programa oferece a possibilidade de escrever breves comentários acerca das categorias e subcategorias, o que favoreceu uma melhor visão do fenômeno estudado.

Do corpus de documentos primários, chegamos à conclusão de que as entrevistas constituiriam a principal fonte de informações, uma vez que elas continham dados relevantes que não poderiam ser obtidos por meio de outros instrumentos. Opinamos que esse diálogo entre os diversos dados foi necessário e fecundo para o entendimento do fenômeno que nos propusemos a examinar.

Mesmo antes que os dados fossem completamente sistematizados, fizemos as primeiras inferências, seja pela releitura das observações do caderno de campo ou pela composição dos relatórios, seja pelas transcrições das entrevistas. A seguir, revelamos as inferências e os resultados obtidos ulteriormente à sistematização dos dados.

\section{5 Análises e inferências}

Pensamos ser adequado retomar a seguintes informações, a respeito das turmas e das professoras. As turmas de estudantes foram divididas em três grupos designados T1, T2 e T3, cada uma correspondendo respectivamente a uma

professora, indicadas por P1, P2 e P3. Realizamos 12 entrevistas semiestruturadas: nove estudantes, sendo três de cada turma e três professoras.

Com o apoio do ATLAS.Ti, foram realizadas as leituras e análises das entrevistas das professoras e dos estudantes; à luz do referencial teórico e das observações empíricas, emergiram cinco grandes famílias de códigos (categorias):

(C1) Atividades didático-pedagógicas; (C2) Questões sobre a Prática pedagógica (concepções pedagógicas); (C3) Questões vinculadas à motivação; (C4) Questões vinculadas ao papel do ensino médio; e (C5) Questões sobre avaliação. Dessas famílias emergiram diversos códigos (subcategorias). A fim de tornar compreensível e proporcionar uma melhor visualização, estruturamos o quadro a seguir (QUADRO 2): 
Quadro 2 - Famílias e seus códigos derivadas das entrevistas, observações e questionários.

\begin{tabular}{|c|c|c|c|}
\hline CATEGORIZAÇÃO & ORIGEM & $\begin{array}{c}\text { FAMÍLIAS } \\
\text { (CATEGORIAS) }\end{array}$ & $\begin{array}{c}\text { CÓDIGOS } \\
\text { (SUBCATEGORIAS) }\end{array}$ \\
\hline \multirow{20}{*}{ Dados da Empiria } & \multirow{4}{*}{$\begin{array}{l}\text { A. Entrevistas com } \\
\text { as professoras, } \\
\text { estudantes e } \\
\text { observações. }\end{array}$} & \multirow{4}{*}{$\begin{array}{l}\text { C1. Questões } \\
\text { Didático- } \\
\text { Pedagógicas }\end{array}$} & $\begin{array}{l}\text { Recursos didático-pedagógicos } \\
\text { (formas de mediacão) }\end{array}$ \\
\hline & & & $\begin{array}{l}\text { Exploração dos conhecimentos } \\
\text { prévios }\end{array}$ \\
\hline & & & $\begin{array}{l}\text { Aulas contextualizadas (vida } \\
\text { cotidiana) }\end{array}$ \\
\hline & & & $\begin{array}{l}\text { Operações com conceitos } \\
\text { científicos - Estratégias de } \\
\text { operacão com conceitos }\end{array}$ \\
\hline & \multirow{4}{*}{$\begin{array}{l}\text { B. Entrevistas com } \\
\text { as professoras e } \\
\text { observações. }\end{array}$} & \multirow{4}{*}{$\begin{array}{l}\text { C2. Questões sobre } \\
\text { a Prática pedagógica } \\
\text { (concepções } \\
\text { pedagógicas) }\end{array}$} & Atividades práticas \\
\hline & & & Uso de novas tecnologias \\
\hline & & & Ensinar a partir do interesse \\
\hline & & & $\begin{array}{l}\text { Esforço e capacidade dos } \\
\text { estudantes }\end{array}$ \\
\hline & \multirow{4}{*}{$\begin{array}{l}\text { C. Entrevistas com } \\
\text { estudantes e } \\
\text { observações. }\end{array}$} & \multirow{4}{*}{$\begin{array}{l}\text { C3. Questões sobre } \\
\text { a Motivação }\end{array}$} & Participação dos estudantes \\
\hline & & & Responsividade da professora \\
\hline & & & $\begin{array}{l}\text { Clima da aula (Atenção } \\
\text { distribuída) }\end{array}$ \\
\hline & & & $\begin{array}{l}\text { Demonstração de afeto } \\
\text { (positivo ou negativo) }\end{array}$ \\
\hline & \multirow{4}{*}{$\begin{array}{l}\text { D. Entrevistas com } \\
\text { professoras, } \\
\text { estudantes e } \\
\text { observações. }\end{array}$} & \multirow{4}{*}{$\begin{array}{l}\text { C4. Questões sobre } \\
\text { o Papel do Ensino } \\
\text { Médio }\end{array}$} & $\begin{array}{l}\text { Incentivo ou valorização da } \\
\text { educação }\end{array}$ \\
\hline & & & Escolha profissional \\
\hline & & & Formação para o trabalho \\
\hline & & & ENEM/Vestibular \\
\hline & \multirow{4}{*}{$\begin{array}{l}\text { E. Entrevistas com } \\
\text { as professoras, } \\
\text { estudantes e } \\
\text { observações. }\end{array}$} & \multirow{4}{*}{$\begin{array}{l}\text { C5. Questões sobre } \\
\text { avaliação }\end{array}$} & Concepção de avaliação \\
\hline & & & Instrumentos de avaliação \\
\hline & & & $\begin{array}{l}\text { Estratégias de preparação para } \\
\text { avaliação }\end{array}$ \\
\hline & & & $\begin{array}{l}\text { Função somativa } \\
\text { (classificatória) }\end{array}$ \\
\hline
\end{tabular}

Fonte: Elaborado pelo autor com apoio do programa ATLAS.Ti.

Os dados organizados em famílias de códigos foram desmembrados e analisados separadamente, de modo a facilitar as apreciações. Os códigos (subcategorias) foram considerados e, o quanto possível, feitas as correspondências com as falas dos entrevistados. 


\section{C1 - Questões didático-pedagógicas}

A família $\mathbf{C 1}$ foi a que mais nos chamou a atenção, pela sua complexidade e relações. E foi a que inseriu maior contribuição para a nossa análise, uma vez que teve influência mais direta no processo de formação de conceitos.

Essa família e seus códigos emergiram das entrevistas com as professoras, os estudantes e as observações das aulas, conforme o quadro 2. Destacamos as seguintes códigos: recursos didático-pedagógicos; exploração dos conhecimentos prévios; aulas contextualizadas; operações com conceitos (FIGURA 7).

Figura 7 - Rede semântica de "C1" e suas correlações.

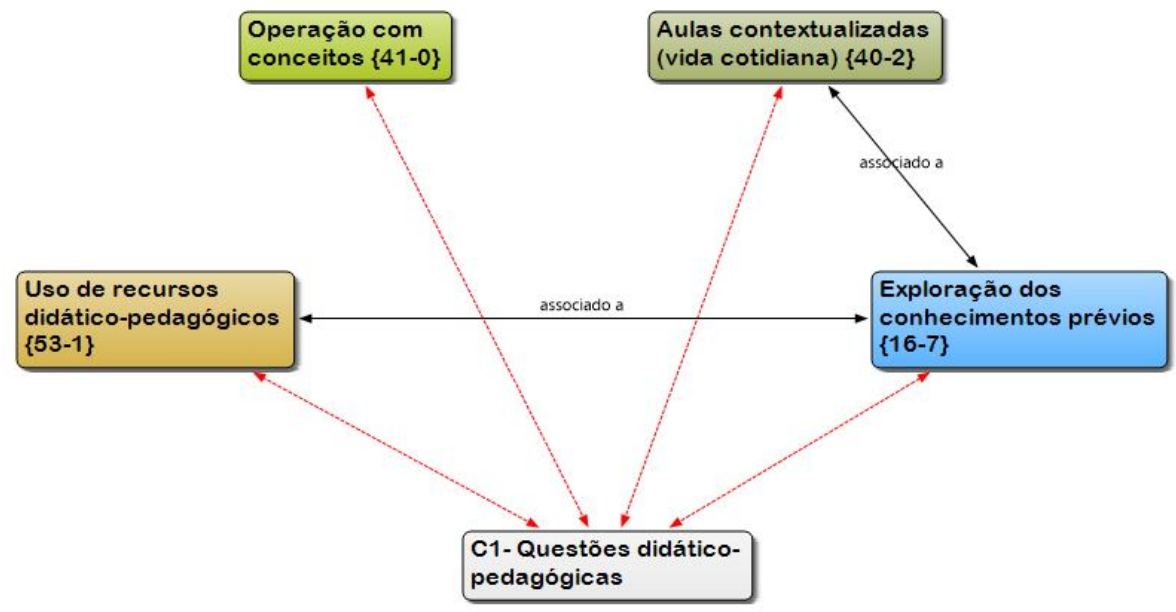

Fonte: Elaborado pelo autor com suporte do programa ATLAS.Ti.

Antes de iniciarmos as nossas análises, cabe um esclarecimento em relação à expressão "questões didático-pedagógicas” da C1. Para a sua criação, apoiamo-nos em Libâneo (1990, p. 16), que entende que essas questões ou atividades são constituídas pela integração entre a área da didática e da pedagogia.

Para melhor entendimento de sua posição trazemos o trecho a seguir,

A didática é uma disciplina de integração que se nutre dos conhecimentos e práticas desenvolvidas nas metodologias específicas e nas outras ciências pedagógicas, com vistas a formular generalizações em torno de conhecimentos e atividades docentes comuns e fundamentais para o processo de ensino. (LIBÂNEO, 1990, 16) 
A didática está relacionada à essência da prática docente, está relacionada diretamente aos meios e técnicas utilizadas no processo de ensino-aprendizagem. O conjunto de atividades que se manifesta a partir da intenção das professoras e as atividades dos estudantes (tarefas), no âmbito escolar, visam à aprendizagem de conceitos científicos. Conforme observado, essas atividades nem sempre são conscientes por parte dos estudantes e/ou professores. No caso das professoras, é lícito afirmar que elas provêm também de crenças ou concepções sobre o processo ensino-aprendizagem. Essas crenças serão mais bem analisadas em C2.

Ainda sobre a família C1, em conformidade com Libâneo (1990, p. 55) a pedagogia é uma ciência que se ocupa do estudo sistemático da educação - do ato educativo, da prática educativa como componente integrante da atividade humana, como fato da vida social, inerente ao conjunto dos processos sociais. Muito embora didática e pedagogia sejam utilizadas indistintamente como sinônimos e estejam intrinsicamente relacionadas, elas não são iguais.

A didática trata dos modos de ação pedagógica na escola, e está ligada diretamente à atividade de ensino, que se desenvolve pelo professor e se caracteriza por ações como dirigir, organizar e estimular a aprendizagem escolar dos alunos que, por sua vez, podem ser desmembradas em operações.

As questões didático-pedagógicas compreendem, portanto, o ato educativo em si, a instrução e os modos ou as atividades utilizadas para atingir o objetivo principal, que é a aprendizagem dos estudantes.

Feitos esses esclarecimentos, passamos às análises referentes ao código Recursos didático-pedagógicos, em que discorremos sobre os recursos materiais e as estratégias de ensino a eles associadas, aplicadas no processo de ensinoaprendizagem. Conforme Saviani (2013, p. 90), apesar de a educação ser uma produção de ordem não material, as ações pedagógicas se dão baseadas em um suporte material. Tal suporte é muito variado. Pode ser desde um livro até o ambiente ou o espaço pedagógico.

Outro aspecto que nos chamou atenção é a associação entre os conhecimentos prévios dos alunos e os recursos e aulas contextualizadas (FIGURA 6), que abordamos nesta seção.

Testemunhamos uma variação nos usos dos recursos didáticos, principalmente pela P1. Quando indagadas sobre qual recurso didático mais utilizavam, as professoras informaram: 
P1. Mais frequente? Ah, assim, eu utilizo mais o livro né, é o livro, o quadro com o giz, dependendo da aula, eu preparo as aulas em Projetor [ahã] né, elaborando slide.

P2. Eu utilizo o livro didático como recurso, mas, o que eu mais utilizo eu, particularmente, prefiro utilizar explicando no quadro. Parece que a aula flui mais do que ficar só no livro, especificamente porque parece que a aula fica mais dinâmica dá pra gente conversar mais, dá pra gente se interagir. Eu prefiro assim, às vezes colocar os tópicos no quadro e trabalhar em cima pra eles ficarem olhando só ali no livro. Eu tenho a impressão que eles não estão lendo, eles não estão acompanhando, aí eles pedem pra algum colega ler, lê muito baixo o outro não tá entendendo, não tá ouvindo. Aí, nem todos têm livros, então eu prefiro colocar tópicos no quadro.

P3. O livro didático. (Transcrição de audiogravação)

Deduzimos que a $\mathbf{P 1}$ foi quem mais utilizou o recurso do Projetor para a exposição dos conteúdos, acentuadamente no primeiro bimestre e no início do segundo. Ela usou o recurso na grande maioria das aulas, possivelmente por ter um aparelho próprio, não dependendo de agendamento prévio na sala de recursos da escola.

As apresentações continham geralmente uma figura, seguida de um conjunto de conceitos (somente palavras). Conforme a $\mathbf{P 1}$ ia descrevendo a figura, ela indicava seus componentes, sua morfologia ou função. Observamos o esforço em reforçar o significado das palavras e pedir que os estudantes repetissem o conceito, geralmente completando uma frase que ela mesma prenunciava.

No decorrer do segundo semestre, a professora passou a utilizar o quadro de giz. Primeiro escrevia os principais conceitos, deixando espaço para completar com o significado ou com os componentes. Geralmente as aulas tinham o mesmo formato. Ela escrevia no quadro, esperava algum tempo para que os estudantes copiassem e, posteriormente, completava com o significado. Algumas vezes recorria ao livro didático para mostrar uma figura ou foto para ilustrar o conceito. Percebemos que a $\mathbf{P 1}$ foi a que teve mais cuidado no planejamento de suas 
atividades de ensino. Observamos que ela estava sempre presente em sua 'hora atividade $^{88}$, com o seu caderno de planejamento.

Ainda em relação à $\mathbf{P 1}$, compreendemos que a adoção de recursos externos e de técnicas instrumentais, de modo planejado, favoreceu os processos ligados à memorização superior, uma vez que imagens estão relacionadas a conceitos. Observamos que, quando esses procedimentos são adotados de forma combinada, têm maior chance de servir ao objetivo de proporcionar as condições para a formação da memória superior ou mediada. Essa suposição teórica baseia-se na premissa de que as funções psicológicas superiores atuam de forma integrada. Apoiado em Vigotski, o neuropsicólogo Luria (1981, p. 214) entende que as funções mentais superiores, como a memória mediada, a fala, o pensamento e a atenção dirigida, por exemplo, têm origem histórica social e a aprendizagem é o modo de desenvolvê-las.

$\mathrm{O}$ uso do projetor para apresentar figuras, esquemas e fotos, aliado à discussão dos fenômenos, mostrou-se um importante aliado para que o estudante passe da condição de receptor de imagem para um construtor de conceitos. Para Vigotski (2001, p. 386), "todo pensamento estabelece uma ligação entre alguma imagem representada na consciência por partes da realidade" e "a maneira como essa realidade está representada na consciência não pode ser indiferente para eventuais operações de pensamento".

Muito embora o pensamento, na adolescência, vá se tornando cada vez mais abstrato, a imagem continua sendo a forma mais adequada para orientar o pensamento e a memória. Ainda segundo o autor, na memória "a palavra pode ser ainda substituída pela representação sobre ela ou por uma imagem de memória, como acontece com qualquer outro objeto" (VIGOTSKI, 2001, p. 422). Esse processo de representar a realidade envolve diversas funções psicológicas, que se formam especialmente no período da adolescência. Na mesma direção, Martins (2013, p. 302) explicita que "a utilização dessas formas instrumentais de ensino, quando utilizado de forma adequada e metódica, favorece a interiorização dos signos e símbolos e a memorização superior”.

${ }^{88}$ A hora atividade é uma conquista dos profissionais em educação, pois representa o reconhecimento do trabalho pedagógico realizado fora da sala de aula. Geralmente é usado pelas professoras para fazer o planejamento das atividades de ensino. 
A P2 raramente utilizava o recurso do projetor em suas aulas. Nas ocasiões em que presenciamos o seu uso, ocorreram imprevistos de funcionamento do aparelho. Um dado importante foi a falta de um local adequado para a projeção. Em uma das aulas, a P2 passou um filme (desenho animado) sobre o tema evolução. O som e a imagem não estavam adequados e acabou por produzir ruído. Em consequência, os estudantes não prestaram a atenção devida. Além disso, não houve tempo para o término na mesma aula, e a professora reapresentou em outra aula. Não houve discussão do assunto. A nosso ver, esse é um exemplo de uso inadequado de recursos didático-pedagógico. Retomamos a autora já citada, que declara que somente o uso metódico dos instrumentos de ensino pode favorecer o processo de instrução.

Conforme a sua entrevista, e confirmado nas observações, os recursos mais utilizados pela $\mathbf{P 2}$ foram, em primeiro lugar, o quadro de giz; em segundo, o livro didático. $\mathrm{O}$ quadro de giz era utilizado para escrever um roteiro da aula, que era escrito sem que ela dissesse uma palavra. Os estudantes apenas copiavam do quadro. Em seguida, ela iniciava a explicação do conteúdo com base no roteiro e a leitura do livro didático. A observação é de que no início do semestre, nem todos os alunos tinham o livro didático e muitos alegavam ter esquecido de trazer. Em consequência, a professora sugeria que eles se sentassem com um colega para acompanhar a leitura. Essa poderia ter sido uma estratégia interessante de estudos, se bem aproveitada e com outra intencionalidade.

Notamos que, geralmente, as aulas eram enfadonhas, pois ela praticava a mesma configuração de ensino, que consistia na leitura de um trecho do livro, seguida dos comentários do fragmento. A leitura do livro didático era feita por um aluno, ou vários alunos, ou então pela própria professora. Percebemos que muitos estudantes liam baixinho ou tinham dificuldades aparentes de leitura. $\mathrm{O}$ resultado era que os estudantes ficavam muito dispersos, conversando baixinho com outros colegas ou utilizando o aparelho de celular. Durante as explicações da professora, verificamos que havia a necessidade contínua de intervenções para conseguir o mínimo de silêncio e atenção dos estudantes.

A $\mathbf{P 3}$ chegou a recorrer ao aparelho de projeção algumas vezes, mas com pouca frequência, se comparada à P1, que fazia uso em quase todas as aulas, principalmente durante o primeiro bimestre. Porém, constatamos pouco planejamento em relação ao recurso. Em duas ocasiões, em que as suas aulas eram 
no primeiro tempo, a professora foi buscar o aparelho, que não estava disponível, pois ela não havia feito a reserva. O resultado foi que a professora teve que improvisar a aula, fazendo a leitura do livro didático. Pelo projetor, ela mostrava filmes ou documentários baixados da internet.

No entanto, percebemos o esforço da $\mathbf{P 3}$ em relacionar os conteúdos dos vídeos com os conteúdos estudados pelos alunos. Em vários momentos, ela retomava cenas dos vídeos, procurando relacioná-las a certos aspectos do conteúdo e da vida cotidiana dos alunos. Esse aspecto era recorrente, quando empregava esse recurso didático. $\mathrm{O}$ procedimento foi determinante no estabelecimento de diálogos com os estudantes.

Outro instrumento muito usado pela $\mathbf{P 3}$ foi o livro didático, sobretudo na introdução e discussão de conteúdos. Normalmente era a $\mathbf{P 3}$ que fazia a leitura de trechos do livro didático e tecia comentários obre o assunto.

Nas entrevistas, soubemos que não foram elas que escolheram o livro didático, pois a seleção havia ocorrido em anos anteriores. Concordamos com Libâneo (1990), que preconiza alguns cuidados na escolha desse material e no uso pelos professores:

Ao recorrer ao livro didático para a escolha dos conteúdos, elaborar o plano de ensino e de aulas, é necessário ao professor o domínio seguro da matéria e bastante sensibilidade crítica. De um lado, os seus conteúdos são necessários e, quanto mais aprofundados, mais possibilitam um conhecimento crítico dos objetos de estudo, pois os conhecimentos sempre abrem novas perspectivas e alargam a compreensão do mundo. (LIBÂNEO, 1990, p. 141)

Sob o ponto de vista prático, o livro didático é um importante apoio para que os estudantes tenham acesso ao conhecimento. No entanto, segundo Paniago (2013, p. 12), trata-se de um material que acaba por simplificar e resumir os conteúdos e conceitos de que os estudantes deveriam se apropriar. A autora prefere utilizar a categoria Manual Didático, que para ela melhor expressa a sua função. A sua centralidade acaba por reforçar o seu caráter de manual. Outro aspecto considerado é em relação ao seu conteúdo. Paniago, ao analisar o conteúdo sobre questões ambientais, constatou que as informações e as explicações contidas nesses materiais se restringem a constatações de fatos e 
eventos, sem, no entanto, indicar as transformações radicais necessárias à sua superação $^{89}$.

Paniago (2013) identifica diversos problemas referentes à escolha do livro didático ou "manual didático" ${ }^{90}$ : a diversidade de autores; a rotatividade de professores, possibilitando que o professor que escolheu o manual não seja o mesmo que irá adotá-lo; a consonância entre as coleções e a sequência didática proposta pelas escolas; a exiguidade de tempo para as escolhas; e a incompetência do professor na utilização do material.

Assim, a seleção e utilização do livro didático, por parte do professor, passam por questões relacionadas à sua formação acadêmica e às políticas concernentes à questão. Não está no escopo desta tese apreciar em profundidade a questão da formação acadêmica, mas tanto a formação específica quanto a formação didático-pedagógica contribuem para a escolha e a utilização adequada desse material.

Quando as professoras apenas faziam a leitura do livro, mesmo empregando a estratégia de leitura alternada pelos estudantes, havia grande dispersão. Essa estratégia didática mostrou-se pouco produtiva, uma vez que, claramente, alguns estudantes ainda não haviam desenvolvido a fluência na leitura oral. Como não conseguiam realizar uma leitura adequada, as aulas ficavam cansativas, dificultando o entendimento da leitura e a consequente manutenção da atenção por parte dos estudantes, implicando perda da motivação.

Consideramos que, ao detectar que o domínio da linguagem não se dá de forma espontânea, cabe ao professor organizar as atividades de ensino com vistas a contribuir para o seu aprimoramento. Nesse caso, é indispensável selecionar estratégias que propiciem o uso da linguagem oral e escrita, a fim de que os estudantes desenvolvam as ferramentas de transmissão, assimilação e trocas interpessoais. Uma dessas estratégias pode ser a leitura oral individual de textos mais amplos e complexos sobre o tema estudado, visto que o livro didático geralmente é empobrecido de conteúdo. Mas para isso é preciso que o professor organize as ações, de modo a garantir que o processo ocorra de forma ordenada, a

\footnotetext{
${ }^{89}$ Idib., p. 78.

${ }^{90}$ A autora prefere utilizar a categoria "Manual Didático" para se referir ao livro didático, uma vez que, como recurso material de mediação, ele é uma versão simplificada e resumida dos conteúdos escolares.
} 
fim de promover a fluência na leitura e proporcionar a aprendizagem dos conceitos.

Trazemos oura reflexão sobre o livro didático, de Libâneo (1990), que levanta outro problema com esse material:

Os livros didáticos se prestam a sistematizar e difundir conhecimentos, mas servem, também, para encobrir ou escamotear aspectos da realidade, conforme modelos de descrição da realidade consoantes com os interesses econômicos e sociais dominantes na sociedade. (LIBÂNEO, 1990, p. 141)

Para que o professor não seja, apenas, um reprodutor das ideologias e interesses de grupos dominantes, é necessário que estabeleça uma variação das fontes utilizadas para a apresentação do conteúdo. O conteúdo científico não é neutro; é concebido conforme os interesses de uma determinada classe, que é dominante. Essa consideração passa pela formação dos professores. As suas concepções sobre o que é o conhecimento e seus usos são construídas por toda a educação básica, passando pelo ensino médio e pela licenciatura.

Para que os professores tenham consciência dessa realidade, disciplinas como a filosofia, a sociologia e a psicologia da educação podem contribuir para a sua formação crítica. $\mathrm{O}$ critério de escolha do livro didático pelo professor passa pelo entendimento do que seja o conhecimento, a educação e o seu papel no processo de socializar o conhecimento historicamente produzido pela humanidade.

Ainda em relação ao papel do livro didático e da linguagem, de acordo com Martins (2013, p. 303), o desenvolvimento da linguagem oral e escrita representa mais um caso particular de formação de processos autorregulados do comportamento, que contribui para a atribuição de significados e sentidos aos objetos que são percebidos.

Conforme Leontiev (1983, p. 83, tradução nossa), a atividade desenvolvida por participantes de um trabalho coletivo é estimulada pelo resultado obtido. Como já expusemos, os resultados de uma atividade podem ser parciais. Esses resultados, mesmo que parciais, estimulam o sujeito a continuar a executar as 
ações, a fim de atingir os objetivos. Para refletir melhor sobre o valor da linguagem no processo de aprendizagem, recorremos a Leontiev:

Aprender strictu sensu postula sempre o reflexo da realidade de uma forma consciente. Em outras palavras, implica a participação dos mecanismos de reflexos que são de caráter verbal. Ao mesmo tempo, esses mesmos mecanismos se formam no processo de aprender, como resultado do domínio do idioma e da linguagem. (LEONTIEV, 1983, p. 47, tradução nossa)

No caso da estratégia de leitura utilizada pela professora, o estudante percebe o quanto é ineficaz a sua escolha, e não se sente motivado em gastar energia, direcionando a sua atenção. Nesse caso, a leitura é feita de forma mecânica, com repercussões sobre a sua prosódia, comprometendo a aprendizagem. Isso foi observado especialmente nas aulas da P2, em que os estudantes apresentavam maior dispersão, todas as vezes em que ela fazia uso da técnica de leitura alternada, em que um estudante lia um trecho e o outro continuava. A professora mantinha uma voz baixa e uma narrativa sem muita variação na tonalidade, o que contribui, ainda mais, para a dispersão da atenção e o aumento das conversas entre os estudantes.

A partir das observações das aulas e da entrevista, levantamos algumas hipóteses acerca do uso dos recursos didático-pedagógicos pela P2. Existe um conjunto de elementos que contribuem para a sua atividade pedagógica, tais como as habilidades pessoais, a formação acadêmica, a experiência na docência, a presença de um grupo fechado de estudantes, uma relação trabalhista precária, a falta de supervisão e orientação, etc.

Em termos de habilidades pessoais, destacamos a voz baixa, que não atingia toda a sala. Somente em silêncio absoluto é que se podia ouvi-la claramente. Ela mantinha uma relação trabalhista precária, devido a um contrato por tempo determinado. No questionário, vimos que o seu tempo de serviço na escola era o menor das três professoras. Outra observação foi em relação aos conteúdos: ela se detinha especificamente nas informações do livro didático, que exercia a função de manual de ensino. Ela não extrapolava os limites do conteúdo do livro didático. 
Outro aspecto a ser citado é em relação à sua concepção de ensinoaprendizagem. Na entrevista, quando perguntada que outros recursos além do quadro de giz e do projetor gostaria de utilizar, a $\mathbf{P 2}$ fez as seguintes ponderações:

P2: Eu gostaria de usar laboratório. A gente está tentando montar um [...] A gente pensou em montar um laboratório, não necessariamente um laboratório, igual um laboratório. Porque requer recursos bem maiores, a gente quer montar uma sala pra gente utilizar com aulas práticas. Igual ali, que a gente tá fazendo o experimento que tem nesse livro didático que a gente tá utilizando. Eu encontrei esse, eu dei uma olhadinha, tem uma prática de osmose com ovos de aves. Então eu comecei a fazer, a gente está fazendo em sala mesmo. Só que como eu falei pra você.

A gente sabe que aquela turminha que são mais participativos, eles vão ali em cima, eles olham, eles querem olhar, eles querem ficar o tempo inteiro mexendo e outros não, eles são bem mais apáticos. Olham de longe, não se interessam tanto. Esse espírito mais investigador "ah, tá professora, o que a senhora falar é isso ai mesmo" a gente vai, coloca aqui e acabou.

Então, eu acho que uma aula prática, um laboratório, outro ambiente, eu acho que, é eu espero, que comece a instigar a usar a abrir, aquela coisa assim de "ah, eu quero ser um cientista", "eu não quero ser um cientista" "eu quero observar", "eu quero saber", "eu tenho essa curiosidade", então, assim, eu espero que depois dessa sala de atividades práticas que for montar aqui, eles comecem a ter essa curiosidade e mudar essa visão deles. (Transcrição de audiogravação)

Quando a professora fala da possibilidade de repetir a experiência proposta no livro didático, há evidências da sua concepção de construção de conceitos científicos e de ciência. O conceito era apresentado ao estudante primeiro e, depois, era narrada a experiência que deu origem ao conceito. Não detectamos a problematização na introdução dos conceitos. Geralmente eles eram apresentados utilizando o recurso do quadro de giz ou com o auxílio do aparelho projetor. Outro aspecto é a ideia de uma motivação intrínseca do estudante. Ela reclama que os estudantes não se interessam pelos experimentos; ela se refere a eles como "apáticos". O objeto, que é o conhecimento, constitui o seu motivo real, capaz de manter o sujeito na atividade, mas se reduz a um "conceito" que precisa ser memorizado. Assim, a ação do sujeito ocorre sem que o objetivo da ação esteja claro e, como consequência, há a perda ou a redução da motivação, que ela chama 
de "apatia". Assim sendo, entendemos que não importa o material didático utilizado, se a concepção de ciência e ensino-aprendizagem não é clara ou crítica. Para elucidar melhor, transcrevemos a reflexão de Libâneo (1990):

Em resumo, podemos dizer que os métodos de ensino são as ações do professor pelas quais se organizam as atividades de ensino e dos estudantes para atingir objetivos do trabalho docente em relação a um conteúdo específico. Eles regulam as formas de interação entre ensino e aprendizagem entre o professor e os estudantes, cujo resultado é a assimilação consciente dos conhecimentos e o desenvolvimento das capacidades cognoscitivas e operativas dos estudantes. (LIBÂNEO, 1990, p. 152)

São os métodos que movimentam a atividade de ensino, muito embora o método não se encerra em si mesmo. Em nossa compreensão, o método corresponde a uma sequência de atividades e ações com vistas à consecução de certos objetivos. O objetivo, portanto, vem antes do método. O método acaba sendo consequência do objetivo.

Libâneo (2016) é partidário do chamado ensino desenvolvimental, em que é o ensino que impulsiona o desenvolvimento. Nas atividades de ensinoaprendizagem, o professor organiza o ensino de modo que os alunos se apropriem dos métodos e procedimentos de busca dos conceitos científicos e, desse modo, efetivam-se mudanças em seu desenvolvimento mental. Os conceitos científicos e o desenvolvimento das capacidades intelectuais estão em relação mútua.

Em nossas observações, apreendemos que o 'método' escolhido tinha como objetivo obter o 'controle da aula', no sentido de manter os estudantes ocupados de alguma maneira. Esse fato foi verificado principalmente com a P2.

Dentre os fatores que contribuíam para o estabelecimento de uma maior atenção por P1 e P3, observamos o posicionamento corporal, para que todos pudessem vê-las e a manutenção de um olhar dirigido a todos os estudantes. Além disso, suas narrativas eram claramente mais interessantes, uma vez que se esforçavam para variar o tom da voz ao contar a história científica.

Além disso, demonstravam um maior conhecimento sobre os conteúdos, em suas narrativas. Em nossa avaliação, a P1 exibia um melhor desempenho acadêmico. Atribuímos esse desempenho a uma série de fatores, relacionados à experiência profissional e acadêmica. Fatores como a formação em nível 
universitário, experiência profissional em laboratório no ensino superior e um curso de pós-graduação latu senso podem explicar melhor o destaque da sua atuação docente.

Acompanhando a P1, inclusive nos períodos de sua hora atividade, vimos que a professora planejava as suas atividades minuciosamente, Registrava todas as ações em um caderno específico para esse fim, o que se refletia em sua atividade didática, pois a aula fluía melhor, com começo, meio e fim. Os estudantes realizavam a ações com maior clareza dos objetivos. Mesmo que o conceito fosse apresentado pronto, percebemos que a professora se esforçava em introduzi-lo de forma problematizada, destacando as possíveis implicações no cotidiano.

Conforme Libâneo (1990, p. 178), a aula é uma ação conjunta que envolve o professor e os estudantes, cabendo ao primeiro a tarefa de estimular e dirigir. A aula é, portanto, a forma didática básica de organização do processo de ensino. É uma situação didática específica, em que objetivos se combinam com métodos e formas didáticas, objetivando essencialmente propiciar a assimilação ativa de conhecimentos e habilidades. A condução das ações e das operações durante a aula é diretamente responsável pela adequada aprendizagem dos estudantes, podendo culminar com o desenvolvimento dos conceitos científicos.

$\mathrm{Na}$ mesma direção, Galperin (1999, p. 201) estabelece que cabe ao professor, de forma deliberada, criar as condições para que as ações ocorram. Ele deve oferecer as orientações de modo que se eliminem os desacertos. Para o autor, o professor não somente ensina a ação, mas as propriedades da ação. Essa forma de ensinar que o estudante possa utilizar em qualquer outro fenômeno da área caracteriza-se como uma base orientadora de suas próximas ações. Ou seja, diante de um possível novo fenômeno semelhante ao já estudado, o estudante utilizaria o mesmo recurso para a sua compreensão. Por exemplo, o conceito de citoplasma da célula animal é o mesmo para a célula vegetal. São células diferentes, mas que têm uma fisiologia e anatomia muito semelhantes. As ações mentais e/ou práticas que são necessárias para a compreensão de uma contribuem para a compreensão da outra.

Para esclarecer a concepção sobre a função psicológica do material didático, recorremos a Leontiev (1983): 
É evidente que seu objetivo é dar suporte externo às ações internas que a criança realiza sob a direção do professor durante o processo de assimilação do conhecimento. Em si, esse tipo de material também não é objeto direto das ações de aprendizado da criança. De certo modo, é como se representasse apenas esse objeto, já que a criança não aprende a contar cadernos, mas a contar; não estuda os corpos que flutuam ou afundam, mas o princípio da flotação e a lei de Arquimedes; não o aquecimento dos corpos, mas as leis da convecção de calor, e assim por diante. De que menos trata aqui é dar forma concreta às representações, ao conhecimento do aluno; pelo contrário, tratase de generalizá-las. Portanto, o material didático é nestes casos o material no qual e através do qual, se procura a assimilação de um determinado tópico. (LEONTIEV, 1983, p. 211, tradução nossa)

O autor é claro ao afirmar que o material didático desempenha o papel de apoio ao processo de assimilação do conhecimento. O que está em jogo não é o material em si, mas a sua capacidade de dar suporte à aprendizagem de conceitos. O material didático tem a função de promover a materialidade do conceito a ser aprendido pelo estudante, através da instrução. Para Leontiev, uma das tarefas pedagógicas "é encontrar o lugar concreto do material didático, quer dizer, não somente o método para incorporá-lo ao processo pedagógico, mas o método para dirigir este processo, que pode assegurar ou não a utilização formal dos elementos didáticos, senão seu uso efetivo" (LEONTIEV, 1983, p. 216, tradução nossa). Trazemos aqui uma citação de Pirogov ${ }^{91}$, mencionado por de Leontiev, que consideramos oportuna para entender a importância do material didático: "nem o didático, nem a palavra valem por si mesmas sem a habilidade de dirigir como é devido [...] nada eficiente se pode fazer".

Durante as aulas, percebemos que, na maioria das vezes, não havia um roteiro prévio das professoras em relação às ações dos estudantes. Galperin (Galperin, 1954 in Simon, 1957, p. 217, tradução nossa) propôs um conjunto de etapas a serem seguidas pelo professor para se atingirem os objetivos de aprendizagem através da instrução. Essas etapas compõem a condição básica para que a aprendizagem se efetive e, conforme já apresentamos constitui a base orientadora das suas ações BOA.

Desse modo, a BOA deve estabelecer a relação entre a parte material, representada pelos componentes de uma tarefa, e a parte mental da ação, para que

\footnotetext{
${ }^{91}$ Pirogov apud Leontiev, 1984, p. 205.
} 
o estudante haja de forma consciente, com base em conceitos que buscam uma solução ideal para a situação-problema. Este trecho de Vigotski ilustra a questão da necessidade de problematização:

Adiante, quando abordarmos os fatores do desenvolvimento do adolescente, examinaremos um fato há muito observado pela investigação científica: onde o meio não cria os problemas correspondentes, não apresenta novas exigências, não motiva nem estimula com novos objetivos o desenvolvimento do intelecto, o pensamento do adolescente não desenvolve todas as potencialidades que efetivamente contém, não atinge as formas superiores ou chega a elas com um extremo atraso. (VIGOTSKI, 2001, p. 171)

O autor evidencia que é justamente com o auxílio de desafios propostos pelo professor, da necessidade que aparece e é estimulada, e dos objetivos informados que os adolescentes são motivados e conduzidos a dar o passo decisivo no desenvolvimento. Verificamos que esse recurso foi pouco utilizado pelas professoras nas atividades de ensino.

Registramos, ainda, que um conjunto de pequenas ações das professoras, como dirigir o olhar ao conjunto dos estudantes na sala, circular lentamente pelo ambiente enquanto explica o conteúdo, esboçar uma figura no quadro de giz ou escrever uma palavra cuja pronúncia seja mais difícil, contribuiu para manter a atenção dos estudantes e promover a interação com o conteúdo e com os conceitos. Libâneo (1990, p. 179) sublinha que cada aula é única, uma vez que implica a criatividade e a flexibilidade do professor e até alguma perspicácia, para saber como atuar em situações didáticas específicas, cujo rumo nem sempre é previsível. Notamos que, apesar dos esforços das professoras, prevaleceu a improvisação.

Outro aspecto da família $\mathbf{C 1}$ constatado por meio das entrevistas foi o dos conhecimentos prévios, que deram origem à subcategoria de mesmo nome. Apreçamos a exploração desses conhecimentos prévios, por parte dos professores, como uma substancial condição para a formação dos conceitos verdadeiros. Quando o estudante chega à escola, não vem 'vazio' de conhecimento. Ele possui uma série de conceitos espontâneos, já traz consigo concepções sobre o mundo e seus fenômenos. 
Cabe ao professor explorar esses conhecimentos prévios e ensinar os estudantes a partir do que sabem. Trata-se de conhecimentos que, muitas vezes, ainda não foram conscientizados pelo estudante. Essa é uma das condições para que o conceito espontâneo se torne um verdadeiro conceito. É responsabilidade do professor proporcionar aos estudantes as condições para que tenham a noção dos conceitos e operem na realidade. É por intermédio dessa conscientização que se formam os verdadeiros conceitos.

Conforme Vigotski (2001, p. 255), o desenvolvimento intelectual não se dá de forma natural, por um processo de amadurecimento das funções psíquicas, mas por mediações do processo de relações sociais. Esse processo é operacionalizado na escola, por meio da atuação do professor, considerando a Zona de Desenvolvimento Iminente. Portanto, não se trata mais da possibilidade de desenvolvimento natural, mas da necessária participação e mediação de um sujeito mais desenvolvido que, no caso do ambiente escolar, são preferencialmente exercidas pela professora.

Antes de ensinar é necessário, e prudente, ter a noção do que os estudantes já sabem sobre o assunto, com o risco de se tornar repetitivo ou então descartar os conceitos que os estudantes trazem de suas vivências. Esses conceitos podem estar em desacordo com os conceitos construídos pela ciência. Conforme anotamos, a exploração dos conhecimentos prévios por parte das professoras esteve restrita a determinadas aulas.

A exploração dos conceitos prévios, mesmo que de forma pontual, foi feita principalmente pela $\mathbf{P 1}$ e pela $\mathbf{P 3}$, com destaque para a $\mathbf{P 3}$, que demonstrou maiores habilidades em relacionar as novas aprendizagens aos conhecimentos prévios dos estudantes. O sucesso da $\mathbf{P 3}$, pelo que vimos, esteve relacionado ao fato de a professora se valer de uma ação educativa mais dialógica com os estudantes. Essa capacidade dialógica certamente está relacionada às características pessoais da professora, suas experiências profissionais e acadêmicas. Naquele momento, a $\mathbf{P 3}$ era a professora com maior tempo de experiência profissional.

A exploração desses conhecimentos prévios se sucedeu através das ações das professoras, ao propor tarefas ou fazer questionamentos orais aos estudantes no início de cada unidade de estudo. Com esse tipo de ação, o estudante se percebe mais ativo e a aprendizagem pode deixar de ser apenas memorística, 
evitando o privilégio de determinadas funções psicológicas, como a memória e a atenção, e abrindo possibilidade para o desenvolvimento de outras funções, ainda mais complexas, como o raciocínio lógico, a discriminação, a generalização, etc.

Assim, no código conhecimentos prévios esteve intrinsicamente associada ao código conhecimento e vida cotidiana, com 38 citações, que por sua vez esteve relacionada ao da motivação, com 98 citações e participação dos alunos, com 28, conforme expresso na rede semântica (FIGURA 8). Estas foram as duas outras mais importantes códigos da família C1. Essa associação conduziunos a assimilar que a manutenção da participação e da atenção dos estudantes concorre com a subcategoria das aulas contextualizadas.

Figura 8 - Rede semântica exibe a importância das aulas contextualizadas (conhecimento e vida cotidiana).

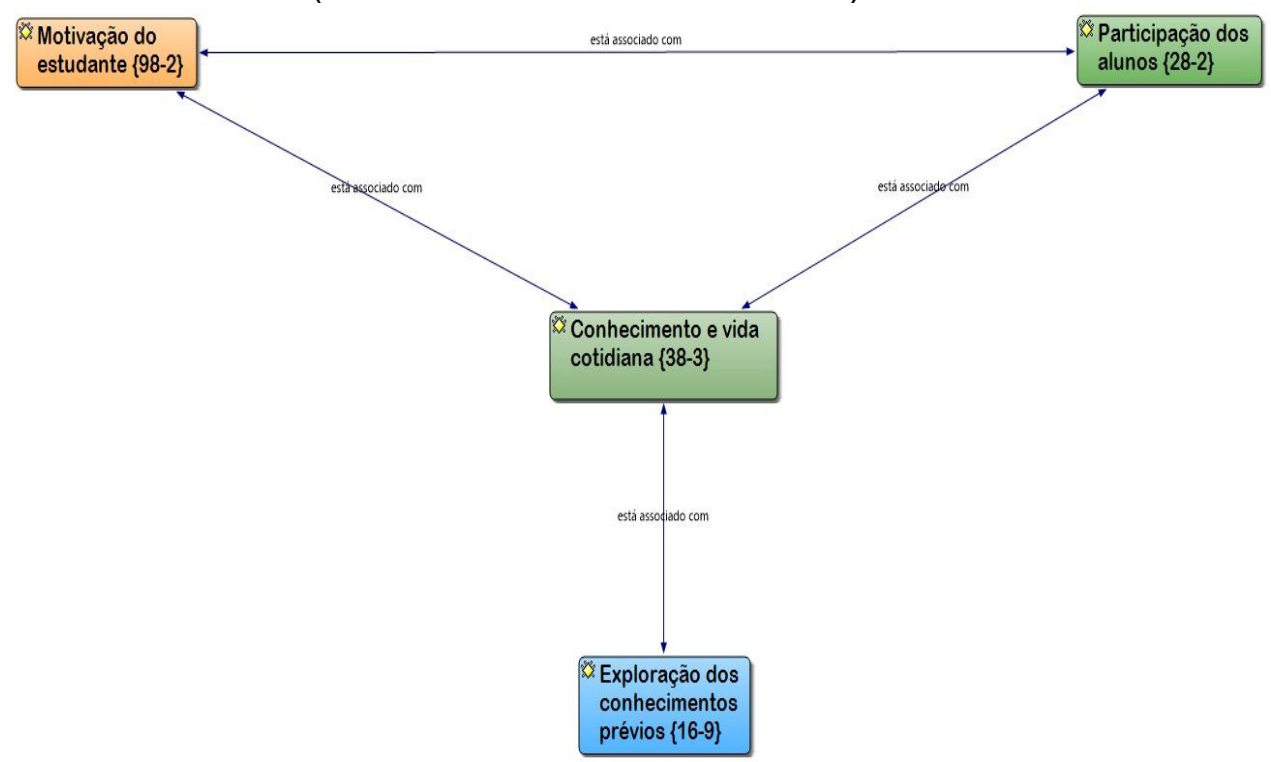

Fonte: Elaborado pelo autor com apoio do programa ATLAS.Ti.

Verificamos que os momentos em que as professoras incentivavam a participação dos estudantes através de questionamentos eram escassos. Podemos supor a existência de uma relação direta entre a forma de apresentação do conteúdo e a participação dos estudantes.

Quando questionados se conseguiam estabelecer a relação entre o conteúdo ensinado e a vida cotidiana, a maioria dos estudantes admitiu a dificuldade de perceber tal relação. Apenas dois estudantes, dos nove entrevistados, disseram associar o conteúdo ao contexto de sua vida cotidiana. A 
P1 e principalmente a $\mathbf{P 3}$ foram as professoras que mais se esforçaram em estabelecer essa relação. Essa operação foi praticamente inexistente na $\mathbf{P 2}$.

Indagados se, antes de ensinar um determinado conteúdo, a professora considerava o que eles já sabiam sobre o assunto, os alunos das três turmas assim se pronunciaram:

Na T1:

A1: Sim, ela procura saber.

A2: Ela pergunta se a gente já sabe.

A3: Acho que ela faz mais uma revisão porque ela, talvez ela achasse que a gente tinha um pouco esquecido né, então, ela procura relembrar mais ou então aprofundar mais o assunto. Talvez.

Na T2:

A4: A professora de biologia. [sim] ela procura saber que a gente, procura pesquisa, pesquisar o que a gente trouxe do fundamental para ela poder passar, como ela fez agora nesse primeiro bimestre com a gente.

A5: Ela pergunta se a gente sabe e se a gente falar que sim, ela resolve passar o outro conteúdo o que a gente não sabe, mesmo assim, tendo um pouquinho daquilo que a gente já sabia.

A6: Nas primeiras semanas de aula, ela fez algumas atividades pra ver o conhecimento que a gente tinha sobre a biologia. Aí, depois que ela fez essa avaliação, ela passou o conteúdo dela pra que a gente entendesse um pouco e começou a fazer provas conforme ela ensinou e explicou em sala de aula com algo novo pra gente, algo diferente, aprimorando mais o nosso conhecimento do que a gente já conhecia.

Para a T3:

A7: Não! Ela já apresenta o conceito. 
A8: Ela parece que assim. Tem dos dois um pouco. Porque é quando pegamos ciências no ensino fundamental, tem umas coisas que no primeiro ano, você vai ver coisas do ensino fundamental não só no primeiro ano, você revisa no primeiro, segundo ano, e terceiro então, ela lembra um pouco. Dependendo da matéria, ela lembra um pouco e ajuda a gente a relembrar aquilo que a gente já tinha estudado e tem, quando não pegamos uma matéria é do ensino fundamental aí é nova, ela explica de outro jeito, então ela não relembra, ela vai explicar como se a gente não soubesse mesmo.

A9: Acho que ela não é muito de questionar alguém durante as aulas dela. De perguntar se entendeu. Mas depende da pessoa, também se ela quiser participar da aula e perguntar, a professora mostra o ponto de vista dela, pra professora se tá errado ou não, e complementar de alguma forma. (Transcrição de audiogravação)

Com base nas respostas dos estudantes e nas observações, interpretamos que os alunos confundem os conhecimentos prévios com os conhecimentos básicos da matéria, além de confundirem a revisão da matéria com o levantamento dos conhecimentos prévios, como o caso em que, para saber dividir, é necessário saber a adição e a multiplicação. Mesmo assim, constatamos que, nos raros momentos em que ele ocorreu, se mostrou eficaz para estabelecer um diálogo com os estudantes e uma situação adequada para introduzir ou explorar um determinado conceito.

Para Libâneo (1990, p. 78), o ensino tradicional baseado na transmissão da matéria, na realização de exercícios repetitivos, na memorização de fórmulas e enunciados é empobrecido e não contribui para o desenvolvimento dos estudantes. Esse ensino que, segundo o autor, fica restrito às paredes da sala de aula, sem a preocupação com a prática da vida cotidiana, deve ser encarado como o ponto de partida e de chegada da atividade docente. A prática social, baseada na realidade social, política e econômica e cultural, deve ser parte integrante da ação de ensino. Dessa maneira, o ensino pode contribuir para o aprimoramento de suas funções psicológicas, levando o estudante a compreender a sua realidade e a se tornar sujeito ativo na sua transformação.

A aplicação de recursos didático-pedagógicos, como questões norteadoras sobre o conteúdo no início da aula, consiste em uma notável ação do professor, que tem o potencial de contribuir para o processo de construção de significados 
pelos estudantes. Outras formas de mediação, como o uso de recursos audiovisuais como Projetor, mostraram-se eficientes em atrair e manter a atenção dos estudantes, desde que a ação tenha uma base de orientação. Muitos dos conteúdos de biologia exigem certa abstração da forma e do funcionamento das estruturas ensinadas. Assim, uma figura representando a sua morfologia, aliada à narrativa da professora, revelou-se uma importante aliada na manutenção da atenção dos estudantes durante as aulas.

Nos diálogos transcritos a seguir, vemos que a P1 introduz os conteúdos através de questionamentos. No processo de observação, não era raro que a P1 se dirigisse aos estudantes com alguma pergunta, muito embora ela mesma respondesse às questões que fazia, como demonstram as sequências SQ1 e SQ4.

SQ1

$<$ P. "como era a Terra antes de surgir a vida?"

P. "qual o nome da estrutura que está no centro do planeta Terra e sai?"

E. "erupção...”

P. "como ela se resfriou?"

E. "por causa da chuva."

P. "formaram-se os mares. O planeta começa a se resfriar."

P. "através das descargas elétricas, formam as primeiras moléculas/reações químicas”

P. "presta atenção no advérbio 'provavelmente' deu origem às primeiras células.">

SQ4

(sobre o microscópio)

$<$ P. "existem vários tipos de microscópios."

P. "por que será que eu utilizo este tipo de instrumento?"

P. "existem seres vivos que não consigo visualizar se eu não tiver o microscópio."

P. "este instrumento serve para visualizar organismos microscópicos - micro."> 
(professora apresenta slide com figuras de células eucariontes e procariontes)

$<$ P. "aqui tem o desenho de uma célula eucarionte. Aqui é uma imagem real de uma célula eucarionte."

P. "qual a diferença?"

P. "qual possui núcleo organizado?"

P. "o que quer dizer núcleo organizado?"

P. "a eucarionte possui núcleo organizado."

P. "olha o tanto de estruturas membranosas no citoplasma."

(diz apontando para a figura do eucarionte)

P. "pro" - primeiro, “eu” - verdadeiro."> (Transcrição de audiogravação)

Essa estratégia de aula dialogada ou semidialogada mobilizou a atenção dos estudantes e criou uma atitude favorável ao estudo, organizando o ambiente, promovendo o interesse e o desejo de conhecer. Para Leontiev (1961 in Longarezi \& Puentes, 2017, p. 51), o interesse é a direção determinada que têm as funções cognoscitivas. $\mathrm{O}$ interesse por uma determinada atividade se dá ao mesmo tempo em que se atua, influenciando não só a atividade futura, mas também aquela que se realiza no momento.

Libâneo (1990) disserta que uma das formas de motivação inicial da aula através de perguntas tem várias funções, como averiguar se os conhecimentos anteriores estão disponíveis; estimular o raciocínio dos estudantes; instigar os estudantes a emitirem as próprias opiniões; e promover a ligação dos fatos e conceitos científicos com as coisas e eventos cotidianos ${ }^{92}$.

Para Martins (2013, p. 298), devido à natureza social dos conceitos científicos, cabe ao professor operar no propósito de que os estudantes obtenham esse conhecimento, de modo a adquirir as máximas conquistas produzidas pelo gênero humano. A educação escolar, nesse sentido, cumpre a sua função de mediadora. O professor apresenta aos estudantes os conceitos e a multiplicidade de signos, ensinando-os a atuar com eles e por meio deles.

\footnotetext{
${ }^{92}$ ibid., p. 178.
} 
Das três professoras observadas, a P1 e a P3 expressaram evidentes habilidades de mobilização da atenção dos alunos através de questionamentos iniciais. Essa capacidade pode ser explicada devido à sua experiência, aliada à sua formação acadêmica e profissional. Conforme expusemos, tanto a P1 quanto a P3 tiveram as melhores formações.

A P1 foi a que mais se esforçou para vincular o conteúdo com aspectos do cotidiano dos estudantes, através da técnica de fazer questionamentos iniciais sobre o tema da aula, como mostramos a seguir. Ressaltamos o empenho da professora para que o seu discurso fosse tão somente acadêmico e 'neutro', relacionado diretamente ao conteúdo. Não ia além do conteúdo científico, extrapolando para questões de ordem, social, ética ou moral, a despeito de sua manifesta religiosidade. Nas sequências transcritas a seguir, inferimos as tentativas de relacionar o conteúdo com a vida cotidiana:

\author{
SQ1 \\ (experimentos de Pasteur sobre a biogênese) \\ <P. "foi de Pasteur que veio a pasteurização." \\ P. "eleva a temperatura, abaixa a temperatura." \\ P. "deu-se o nome de pasteurização em homenagem a Louis \\ Pasteur.">
}

\title{
SQ2
}

(a partir de um conjunto de conceitos escritos no quadro, a professora introduz o assunto origem da vida)

(em outra aula ela retoma a pasteurização)

$<$ P. "a pasteurização é um método de elevar e abaixar a temperatura. Ele abaixa. São temperaturas adequadas para não modificar as propriedades do alimento."

P. “da pasteurização surgiram os alimentos enlatados.”>

SQ3

(figura sangue com hemácias - sobre a célula e o microscópio) <P. "os glóbulos brancos são células de defesa." 
P. "se você corta a pele, eles vão lá defender."
P. "ele vai lá e forma o pus."> (Transcrição de audiogravação)

A professora $\mathbf{P 3}$, assim como a $\mathbf{P 1}$, também se esforçou para a vinculação do conhecimento com a vida cotidiana, mesmo que com uma direção voltada para questões de ordem ética e moral. A professora fazia questão de ressaltar o que ela considerava certo ou errado na conduta. Destacamos duas sequências (SQs) que evidenciam o esforço em estabelecer a relação do conteúdo estudado com a vida cotidiana, as SQ1 e SQ6 da P3:

\section{SQ1}

<(a professora fala da preservação do bioma Pantanal e da poluição)

P. "na cidade vizinha temos uma usina termoelétrica."

E. "o que é isso?"

P. "uso da tecnologia tem custo"

P. "quantos celulares vocês tiveram?"

(referindo-se ao descarte das baterias)

P. "CFC gases mais agravantes da camada de ozônio."

(ao se referir à geladeira)

P. "se vazar vai prejudicar a camada de ozônio"

P. "presente nos freezers e ar condicionado."

P. "O CFC está sendo substituído por outros gases"

P. "gases ecológicos."

P. "será que não tem risco ao meio?">

SQ6

$<$ (sobre uso indiscriminado de antibiótico)

P. "o governo percebeu que havia automedicação."

P. "a estimativa é de que em 20 anos esse próprio antibiótico não será suficiente para combater essas bactérias.” 
P. "tuberculose. Por exemplo."

P. "tuberculose se inicia com uma tosse. Como se fosse uma gripe."

P. "o tratamento da tuberculose dura meses."

P. "no segundo mês, o indivíduo sente uma melhora ‘tô bem' e para de tomar o medicamento"

P. "você eliminou todas as bactérias?"

P. "aí volta a ficar ruim."

P. "a pessoa volta a tomar o medicamento."

P. "só que as bactérias ficaram mais resistentes, tem que ser outro medicamento."

(estudantes ficaram um pouco distraídos)> (Transcrição de audiogravação)

Conferimos, durante as observações, que o estudante é estranho ao produto da sua atividade, que pertence a outro. Apesar da tentativa da $\mathbf{P 1}$ em relacionar o conteúdo com o cotidiano, os estudantes não se sentem estimulados a participar da aula. O estudante é alienado do produto da sua atividade escolar, uma vez que ela deixa de ser uma manifestação essencial de sua vida tornando-se um 'trabalho forçado', visto que não é voluntário, mas determinado pela necessidade externa. De acordo com Leontiev (1983, p. 85, tradução nossa), nem sempre a atividade e o objetivo estabelecem uma realidade coincidente. E como o estudante vive em um sistema de atividades, ele pode perder o objetivo de sua ação.

Essa necessidade externa é o próprio mercado de trabalho, nesse caso representado pela preparação para o Exame Nacional de Ensino Médio - ENEM e o vestibular, mas se manifestando de formas diferentes, dependendo das diversas classes sociais. Acaba que suas necessidades de compreensão dos fenômenos do mundo através da construção de conceitos científicos são prejudicadas pela necessidade imperiosa das exigências do mercado de trabalho.

Ficou evidenciado que as professoras tinham muitas dificuldades em estabelecer a relação do conteúdo ensinado com a vida cotidiana. O que testemunhamos foi um distanciamento entre a vida cotidiana e os conhecimentos científicos. Isto ficou bem claro nas respostas que os estudantes deram quando 
indagados pelo pesquisador se eles costumam relacionar os conceitos aprendidos com a vida cotidiana:

IA1: Quase nunca.

IA2: Eu não consigo usar, não, só quando problema é por quilo por tal e muito. Quando eu vou lavar vasilha, lembro que a professora falou que em todo ambiente sujo tem bactérias. Então eu uso muita higiene para não pegar bactéria.

IA4: Eu acho que ele está longe da vida cotidiana da gente. Nos ajuda bastante em alguns pontos, caso a gente queira exercer uma profissão que tenha a ver assim, ajuda, mas no nosso cotidiano...não. (Transcrição de audiogravação)

Por meio da fala dos estudantes e das observações feitas, apreendemos o quanto o conhecimento ensinado está distante do cotidiano dos estudantes, apesar dos esforços das professoras em fazer essa relação. Também detectamos que estudantes e professoras têm percepções diferentes sobre a relação entre o conhecimento e a vida cotidiana. Às professoras foi feita a seguinte pergunta: "Em que medida você avalia o uso dos conceitos de biologia pelo estudante na sua vida cotidiana?" As professoras têm uma percepção ambígua dessa questão, como mostram os trechos transcritos a seguir:

IP1: Eu acho assim, que eles aprendem aquilo que está ao redor deles. Que nem, eu estou começando plantas agora. O segundo bimestre inteiro é sobre plantas. Então, eles sempre estão, no dia a dia, vendo plantas, mas não tem, aquele...conceito do que é aquilo, é simples, é complexo, né? Eles começam a ver, "o musgo é a planta mais simples que tem", "a laranjeira é a mais complexa, por que tem fruto, flor vistosa". Então eu acho que começam a ver ao redor deles, é...como que eu posso falar...eu acho que de certa forma, valorizar...eu até / as minhas aulas quando começo explicar sobre isso. Eu instigo a eles a valorizar as coisas ao redor deles, porque é complexo tudo ao redor dele, né? E eu falo até assim, "é muito lindo". Você vê um musgo, a planta mais simples ((fala baixinho, enfatizando as palavras)) "ela é tão pequenininha". Então, eu começo a instigar pra ele perceber, né. E acabar valorizando aquilo, porque é lindo. Porque é bonito ((gesticula muito com as mãos)) né? Olha e "daí a planta vai complexificando", que são as pteridófitas, as samambaias. Aí elas já são maiores. 
A reprodução é interessante no seu ambiente natural. É diferente quando ela é ornamental, então eles "Nossa! Lá em casa tem, professora, essa daí". Aí, chega lá em gimnospermas, elas são de ambientes frios. Mas tem plantas que vivem no ambiente quente, né?

Que nem aquelas que parecem árvore de natal, eu já vi em Corumbá, mas consegue viver em ambiente quente. Mas os pinheiros não conseguem [ahã] e são gimnospermas, têm que viver lá no sul do Brasil. Então, eles começam a ter noção. Acho que assim, de certa forma, eles começam a valorizar as coisas, né? [...] Que eu explico a forma, a percepção que eu tenho é a questão de valorizar ao redor deles, tendo conhecimento, eles começam a ter amor, ao redor [entendi] entendeu? É mais isso, que a minha percepção é isso e esse feedback com eles, falando pra mim ah, sim, é verdade, tal [ahã] entendeu? [ahã]

IP2: Eu acho que, como é o primeiro ano, eles já estão trabalhando com célula, porque a gente tem que começar com célula até chegar a ecologia, né [sim].A gente consegue isso. Porque a gente já estudou tudo isso [ahã] pra eles, é um pouco mais difícil trabalhar essa relação, né. Se fosse claro o segundo ano, a gente já trabalha com seres vivos, é muito mais fácil com os seres vivos.

Com todos os reinos, né [sim]. Então, é muito fácil, pegar e explicar. Mostrar pra eles uma planta, né. Que eles estão vendo ali. Que eles, palpável, do que uma célula [ahã] do jeito que eu falei. A gente não tem um laboratório. Mesmo que a gente tivesse um laboratório, seria muito mais difícil a gente observar uma célula. Então, é um pouco mais difícil essa parte celular. Essa parte ao nível celular, essa citologia. Para eles, eu acho que é um pouquinho mais difícil.

Por isso do desinteresse deles. Porque eles não têm como levar isso aí pro dia a dia. A não ser da reprodução, que a gente vê núcleo, que é depois da divisão celular. Isso eu sei que eles conseguem fazer essa relação. Porque na reprodução, eles estudam reprodução de uma forma geral, a sexuada e assexuada, de repente a gente vai estudar a reprodução humana a partir do momento, passa o conteúdo de reprodução humana. Eles conseguem entender mais porque é uma coisa que eles, ali, no dia a dia. Tem a questão de menstruação, a questão de relação entre pessoas. Da gravidez, tudo isso eles absorvem bem mais fácil. Porque eles conseguem trazer para o dia a dia deles.

IP3: Eu acho que depende muito do conteúdo. Eu acho assim dessa maneira, depende muito do conteúdo. É diferente de você chegar e abordar genética no terceiro ano, é que daí você vai 
falar, olha o sangue. Eu até brinco com os meus estudantes, falo assim: Gente, professora, como que a mãe A. Vamos dar um exemplo: a mãe é A e pai é B, teve um filho, Ó meu Deus', aí os estudantes vão falar: saiu o filho do tiquinho néo, filho do vizinho, né por que na ideia deles, A e B, vai sair o O. Porque na genética não trabalha dessa maneira. Então, fica até mais fácil para eles poderem compreender, porque é algo que eles estão vivendo ali [ahã]. Tem alguns que, dependendo, depende do conteúdo realmente, da importância que é enfatizada lá fora, né? (Transcrição de audiogravação)

Para P1, a relação entre o conteúdo e a vida cotidiana é vista como algo natural do processo. Para ela, quando os alunos aprendem o conceito, são capazes de relacioná-lo com a vida cotidiana. Ela enfatiza a atividade de ensino como forma de tentar imprimir, nos estudantes, uma admiração pelo conteúdo. Dessa maneira, percebemos que as suas narrativas científicas são como narrativas de histórias. Ela elevava ou abaixava a voz para que os estudantes acompanhassem as suas narrativas. Usava exclamações e fazia perguntas que ela mesma respondia. Quando P1 fazia a relação com a vida cotidiana, não extrapolava o conteúdo em si. Quase nunca provocava dilemas ou apresentava a sua opinião.

No caso da P2, a princípio ela afirmou ser difícil para os estudantes estabelecerem a relação com a vida cotidiana; explicou que a questão está nos conteúdos. Depois ela disse que alguns conteúdos favorecem a relação. Por exemplo, os conteúdos referentes à reprodução humana, que seria um tema mais próximo da realidade dos estudantes. Isso remete a uma concepção vivencial/espontaneísta independente da prática educativa, vinculada à ideia de aprender um conteúdo experimentando, através de situações escolares em que o estudante esteja diretamente envolvido, que acontece naturalmente, sem cobrança.

Registramos, na P3, um grande esforço pessoal em fazer as relações com o conteúdo estudado. Por diversas vezes empenhou-se em extrapolar os conteúdos para fazer a relação com a vida cotidiana e, ao fazê-lo, enfatizava questões éticas e morais. Por vezes refletia sobre o que achava que era certo e o que era errado. Mas, ao mesmo tempo, na sua fala, explicou que depende do conteúdo para fazer a relação.

Com essas falas, vimos a dificuldade que as professoras têm de compreender a necessidade de que os conteúdos ensinados sejam conectados à vida cotidiana dos estudantes. Além disso, falta o entendimento de que essa forma 
de instrução possibilita a construção efetiva dos conceitos científicos e a compreensão da realidade em sua essência. Para Libâneo (1990, p. 182), é necessário compreender que a atividade educativa não se restringe ao simples domínio do conhecimento, mas que acaba por contribuir para o desenvolvimento da própria personalidade dos estudantes, e na sua relação ativa com a realidade, com a vida cotidiana.

A P3, por vezes, procurou estabelecer um diálogo adequado com os estudantes, buscando a ligação entre conteúdo e vida cotidiana. Sua fala era claramente informativa e monológica, ou seja, somente a professora discursava. Também constatamos a tendência em 'dar conselhos' aos estudantes, como nesta SQ4:

\section{SQ4}

$<$ P. "todo mundo tem conhecimento aqui."

P. "tem camisinha masculina e feminina."

P. "O anticoncepcional auxilia na prevenção da gravidez"

P. "a puberdade na mulher inicia primeiro que no homem"

P. "o fluxo pode adiantar, atrasar ou provocar dor"

P. "o anticoncepcional auxilia, vem para ajudar nessas coisas"

P. "existem jovens infectados pelo HPV"

P. "A vida da mulher é o ovário, é sua atividade"

P. "doença não tem cura"

P. “jovem enfia o pé na jaca”

P. "você tem que primeiro se amar."> (Transcrição de audiogravação)

Vemos que a P3 se esforçava para estabelecer um maior diálogo com a T3, uma vez que procurava associar o conteúdo a alguns aspectos do dia a dia dos estudantes, principalmente abordando questões da saúde ou locais. A ação das professoras, na promoção de diálogos coletivos, pode oferecer uma direção na atenção dos estudantes. A instrução planejada, visando à problematização da realidade, auxilia na manutenção da atenção dirigida dos estudantes, favorecendo 
a apreensão do conhecimento. Esse fato ficou reconhecido nas aulas da P1, que foi a professora que demonstrou planejar e executar conforme o plano de aula previamente determinado.

Averiguamos que essa atividade é mais efetiva quando ocorre de maneira organizada e planejada. Vigotski (2012, p. 268) destaca o papel do ensino como orientador do desenvolvimento do estudante, concorrendo para a formação de conceitos científicos. Segundo ele, o desenvolvimento do conceito científico se produz durante as condições do processo de ensino, que se configura como uma forma particular de cooperação entre o professor e o estudante. É dentro dessas relações que amadurecem as funções psicológicas superiores, com a mediação do adulto.

Para Vigotski (2012, p. 271), o ensino de conceitos científicos prontos e acabados, ou o ensino direto deles, não resulta na construção de generalizações, mas numa assimilação irreflexiva de palavras. Essa realidade encobre um vazio, um defeito do ensino escolástico e verbal de ensino, que substitui o domínio dos conhecimentos claros pela assimilação de esquemas verbais, através da transmissão mecânica e automática.

Vigotski faz distinção entre os conhecimentos cotidianos e científicos, cuja diferença reside no processo de desenvolvimento. Os conceitos cotidianos constituem as bases pelas quais são construídos os conceitos científicos. A principal característica dos conceitos científicos é sua dependência do processo de instrução escolar. Os conceitos científicos apoiam-se, indispensavelmente, em certo nível de amadurecimento dos conceitos espontâneos. Para Vigotski (2012), o desenvolvimento dos conceitos científicos resulta possível somente quando os conceitos cotidianos alcançam um determinado nível ${ }^{93}$.

Comungamos com as ideias de Sforni (2003, p. 56), para quem o ensino de conceitos segue o caminho da lógica formal, utilizado tanto pela psicologia quanto pela didática. Esse caminho baseia-se na constituição de imagens vivas, de observações realizadas, e o trânsito do sensorial, concreto e singular ao mental, abstrato e geral pode ser observado em ambas. No seu estudo, a pesquisadora vê o ensino de conceitos fundamentado na lógica formal como insuficiente para prover os sujeitos com aptidões necessárias para viver o mundo complexo, mediado por

\footnotetext{
${ }^{93}$ Ibid. p. 285
} 
conceitos, códigos e signos, que não são diretamente assimilados pela percepção ou por raciocínios lineares.

Em síntese, o ensino ministrado pelas professoras segue os princípios da lógica formal, uma vez que estão mais interessadas na estrutura do raciocínio e do conhecimento dos estudantes. O conhecimento é apresentado como algo pronto e acabado. Aspectos como a inserção dos fenômenos dentro de uma totalidade, movimento e contradição, aspectos do raciocínio dialético não estão presentes nos seus discursos e narrativas científicas.

Ressaltamos que a introdução de conceitos como algo pronto e acabado pouco contribui para o desenvolvimento das funções superiores. Na mesma direção de Sforni (2003, p. 94), concluímos que, se o ensino de conceitos não estiver intencionalmente organizado, visando a desenvolver ações e operações mentais de forma qualitativamente superiores, não haverá desenvolvimento. Essas ações não ocorrem meramente em razão de o estudante estar em contato com as generalizações e abstrações apresentadas pelo professor. Em nosso entendimento, a utilização de uma metodologia de ensino, fundamentada nas propostas de Galperin, é uma forma de orientação didática que pode auxiliar o professor no ensino de conceitos científicos.

\section{C2- Questões vinculadas às "crenças" e concepções pedagógicas das professoras}

Passamos a analisar outra importante família, que designamos de C2, que se refere às "crenças" e concepções pedagógicas das professoras. Essa família emergiu essencialmente das entrevistas com as professoras e das observações das aulas. Essa família vincula-se intimamente com todas as outras famílias. As questões referem-se essencialmente às concepções das professoras sobre as práticas pedagógicas que reputam como eficazes no processo de ensinoaprendizagem.

Da família C2 emergiram quatro códigos, assim divididos: (1) atividades práticas; (2) uso de novas tecnologias; (3) ensinar a partir do interesse; (4) esforço e capacidade dos alunos (FIGURA 9). 
Figura 9 - Rede semântica de "C2" e seus códigos.

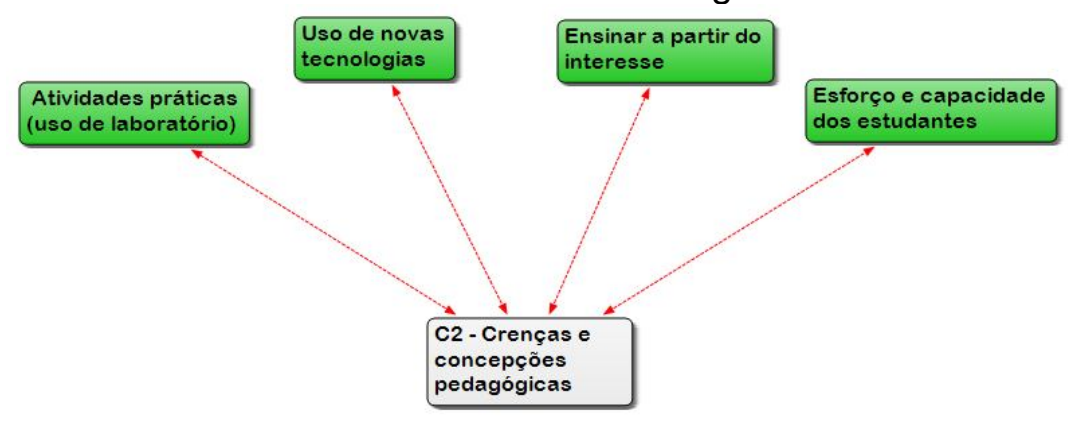

Fonte: Elaborado pelo autor com apoio do ATLAS.Ti.

As concepções pedagógicas das professoras são advindas da formação inicial, seja pela observação dos professores em seus estágios, das teorias estudadas, ou das chamadas microaulas, haja vista que todas cursaram licenciatura, e/ou da imitação de um professor estimado. Possivelmente também faz parte dessas concepções e crenças a formação continuada. Essas crenças e concepções acabam por orientar as suas práticas. Segundo Saviani, podem ser agrupadas em duas grandes tendências:

[...] do ponto de vista da pedagogia, as diferentes concepções de educação podem ser agrupadas em duas grandes tendências: a primeira seria composta pelas concepções pedagógicas que dariam prioridade à teoria sobre a prática, subordinando esta àquela sendo que, no limite, dissolveriam a prática na teoria. A segunda tendência, inversamente, compõe-se das concepções que subordinam a teoria à prática e, no limite, dissolvem a teoria na prática. (SAVIANI, 2005, p. 2)

Assim, segundo o autor, no primeiro caso, a ênfase está em 'como ensinar', portanto, está centrada no professor e na instrução; no segundo grupo, está em 'como aprender', ou seja, centrada no estudante. Assim, sem querer fazer nenhum enquadramento das professoras, em uma ou em outra tendência, o acompanhamento das sequências didáticas das professoras desvelou que as suas concepções estão fundamentadas, em grande medida, na noção da escola tradicional, onde o professor, o método de ensino e a avaliação verificativa, conforme vimos em $\mathbf{C 4}$, ocupam um lugar central no processo.

Nesse sentido é que desta categoria emergem as concepções sobre o uso de instrumentos de ensino, as atividades práticas e as capacidades dos estudantes. 
Sobre as atividades práticas, foi feita a seguinte questão às professoras: "Quais outros recursos ou atividades pedagógicas você considera úteis para melhorar o ensino?". As professoras assim responderam:

P1: Assim, se tivesse laboratório, é isso? Pode ser isso? [não sei, pode ser] nossa, isso iria ajudar e muito o ensino para os alunos. Entende? Que nem assim. Esse ano eu comecei a trabalhar com inseto, a gente não tem espaço pra montar as caixas entomológicas, com insetos, tal, então eu tenho que levar em sala de aula o meu material e falar pra eles trazerem o que eles têm e montar. Ensinar ele a montar inseto, classificar os insetos, entendeu?

P2: Que eu gostaria de usar? Laboratório! Que a gente está tentando montar. A gente estava conversando com o coordenador do ensino médio. Como ele é biólogo, ele ajuda bastante, então. Assim, a gente pensou em montar um laboratório. Não necessariamente um laboratório, igual um laboratório. Porque requer recursos bem maiores. A gente quer montar uma sala pra gente utilizar com aulas práticas igual ali, que a gente tá fazendo o experimento que tem nesse livro didático. A gente tá utilizando, eu encontrei esse, eu dei uma olhadinha, tem uma prática de osmose em ovos de aves então eu comecei a fazer. A gente está fazendo em sala mesmo, só que, como eu falei pra você. A gente sabe que aquela turminha que são mais participativos, eles vão ali ficam em cima, eles olham, eles querem olhar, eles querem ficar o tempo inteiro mexendo e outros não, eles são bem mais apáticos, olham de longe, não se interessam tanto esse espírito mais investigador. Dizem, "ah, tá professora, o que a senhora falar é isso aí mesmo, a gente vai, coloca aqui e acabou". Então eu acho que uma aula prática, um laboratório, outro ambiente, eu acho que é, eu espero, que comece a instigar a usar, a abrir, aquela coisa assim de "ah, eu quero ser um cientista", eu não quero ser um cientista, eu quero observar, eu quero saber, eu tenho essa curiosidade. Então, assim, eu espero que depois desse, dessa sala de atividades práticas que for montar aqui, eles comecem a ter essa, mudar essa visão deles.

P3: [...] Aí, outro exemplo, seria um material prático, nem que fosse uma pequena, é um, uma sala, pontinha, singela, com um microscópio, né. [...] ou se não, ele quer aquele contato com o microscópio, eu observo que estou falando sobre a microscopia. Sobre a citologia, eu vejo que, eu acho que se eles tivessem se deparando com o microscópio, nem que seja o ótico, né. Já é um conhecimento melhor, poxa, eu utilizei, eu consegui focar, analisar aquela imagem, né? Eu acho que a gente tá falando, talvez alguns estivessem analisando, pensando, outros, já, até saiu um pouco do foco, talvez, um material didático, ali, seria 
né, complementaria as nossas aulas de biologia. (Transcrição de audiogravação)

Como percebemos nas falas das professoras, existe a crença, a nosso entender exagerada, de que a atividade prática de laboratório seja essencial para que os estudantes apreendam alguns dos conceitos da área de biologia. Muito embora consideremos o laboratório como importante aliado no processo de ensino-aprendizagem, as concepções de sociedade, de educação e de desenvolvimento ocupam um papel que consideramos primordial. Devido à ênfase em suas falas, principalmente da $\mathbf{P 1}$ e da $\mathbf{P 2}$, em relação ao uso do laboratório e das atividades práticas, consideramos que a atividade instrumental, embora não tenha sido evidenciada no período de observação das aulas, ocupou lugar de destaque em seus ideários.

A P2 considera que a prática é uma forma de lidar com a apatia dos estudantes, porque a atividade em laboratório pode levar os alunos a adquirir o desejo de se tornarem pesquisadores. Isso está de acordo com a concepção ligada à segunda tendência, onde o eixo se desloca do lógico para o psicológico. No caso, o aspecto em tela é a motivação. Essa compreensão parte de uma representação do pesquisador como aquele sujeito que fica fechado no laboratório, planejando e executando os seus experimentos, numa espécie de caricatura da atividade científica. Como dissemos, essas crenças advêm da formação inicial e das representações sociais que os professores trazem de suas vivências.

Nenhuma das professoras chegou a mencionar outros recursos didáticos, a não ser o laboratório. A P2 lembrou que o livro didático traz experimentos que poderiam ser repetidos na sala, mas não os realizou. A P3 mencionou a necessidade da disposição de uma sala para usar como laboratório. Chegou a se referir a "um único microscópio", demonstrando a inexperiência do uso dessa forma de ensino, pois a sala possuía mais de 40 estudantes.

$\mathrm{Na}$ mesma direção está a crença no uso das novas tecnologias. Esta foi uma importante subcategoria da C5. Sob nosso ponto de vista, essa representação do uso das novas tecnologias no processo de aprendizagem provém de um 'fetichismo'. Parte-se de uma representação positiva, idealista e fetichizada sobre a tecnologia, como algo incrível e capaz de encantar e transformar positivamente a condição humana. 
No caso da educação, as novas tecnologias são vistas como um remédio para as questões relacionadas ao processo de ensino-aprendizagem. Em nossa pesquisa, encontramos essas representações do uso das novas tecnologias no processo de ensino. Para elucidar essa questão, trazemos aqui alguns trechos das respostas das professoras quando perguntamos sobre outros recursos que elas gostariam de utilizar no processo de ensino. Apesar de as citações serem longas, acreditamos que exemplificam bem a opinião das professoras sobre o uso das

novas tecnologias e evidenciam as suas crenças:

P1: Eu estou muito interessada naquela lousa digital. Só que o problema é que a escola não tem estrutura, né, porque precisa pregar na parede um aparelhozinho. Aí não tem como. Tem muito aluno e a sala de tecnologia é pequena, né, aí eu fico assim. Ela já chegou a orientar a gente que pode levar um quadrinho. O quadro é pequenininho. Aí, pra utilizar em sala, não dá. Mas eu estou interessada nessa lousa digital.

P2: Eu estou utilizando, um pouquinho, o DARUMA (Projetor). Só que aí, eu percebi, com essa turma que eu estou trabalhando, no seu caso, que você está pesquisando. Eu percebi que eles são, eu não sei se eles levam mais na brincadeira, eles ficam mais dispersos. Porque é assim, eu passei uma aula, por exemplo, membrana plasmática, não, membrana foi essa última. De células procarionte e eucarionte. Para iniciar este estudo da célula, eu percebi que eles ficaram muito dispersos. Eles conversam muito e essa questão de conversar...como eles estão se adaptando ao ensino médio, né, eles vieram do fundamental eles ainda têm, não têm essa maturidade de ouvir. De saber ouvir, saber pegar aquelas informações todas que a gente vai passando no slide. Porque a gente sabe, que uma aula ali você fica anotando. Eles não têm o hábito de anotar, de questionar e de perguntar. Se eles têm dúvida, eles vão com dúvida para casa, eu sei, e aí depois e depois as dúvidas surgem. A gente sabe, né, então eu percebi assim, que mesmo eu utilizando o DARUMA, no caso, que é o projetor pra poder colocar essa aula em slide, eu percebi que eles, que assim fica muito vago. Eles conversam muito, eles acham que não é uma aula normal. Eles já estão acostumados com aquela coisa de quadro. Eu falei pra eles, eu quero mostrar como é uma célula, porque só mostrar assim, pelo livro, acho que fica muito assim, muito vago, muito distante, nem todos enxergam, né. Eu queria realmente pra mostrar como é que seria a diferença entre uma célula e outra, né, pra ver os componentes celulares, que eu digo, eu percebo que eles ficam muitos vagos, então eles não têm essa maturidade de observar o slide e absorver o máximo. Pra eles é uma aula diferente, legal e só e aí, eles ficam muito dispersos. 
P3: Que eu não tenho e ainda não utilizei, né? No caso, utilizar mais a sala de tecnologia, eu utilizo o recurso midiático que é o DARUMA, mas a sala de tecnologia, teria um ambiente melhor. Porque eu estou retirando, eu tô tirando, só o fato de tirar o aluno da sala que ele tá ali, cotidianamente, praticamente todos os dias, já é uma mudança de ambiente pra eles. Dentro da sala de tecnologia eu teria outros recursos, como: eu teria o acesso ali, à internet como a alguns vídeos. Porque, infelizmente, tem alguns vídeos que a gente não consegue fazer o download e são vídeos muitos bons para utilizar em sala de aula, alguns recursos, mesmo de slide, que não tem como fazer o download, então, nós teríamos que ter um material, é visual ali. No caso da internet na sala de aula, no caso, não tem esse acesso. (Transcrição de audiogravação)

Nas observações das aulas, especialmente da $\mathbf{P 2}$ e da $\mathbf{P 3}$, que foram as que mais fizeram uso do Datashow, com o objetivo de tornar a apresentação do conceito mais atraente. Nesse caso, não haveria nenhum problema. No entanto, novamente o privilégio foi deslocado, dos aspectos lógicos do conteúdo, para os psicológicos; dos conteúdos para os métodos; do esforço para o interesse. Tal deslocamento tem a ver com o papel atribuído às novas tecnologias, como forma de promover a motivação e fixar a atenção dos estudantes. O que vimos foi uma convicção de que o ensino através do uso das novas tecnologias poderia despertar o interesse dos alunos. Ele seria capaz de motivar os alunos para a aprendizagem, tornando-a mais eficiente.

As professoras pensam que os alunos são portadores de uma falta de iniciativa ou apatia própria deles, com expressões como "eles são assim", "você os conhece, adolescentes são assim mesmo", etc. Isso nos remete a uma compreensão do ser humano a partir de uma natureza humana, e não das condições que o sujeito experimenta.

As professoras não tinham um planejamento de aula, notadamente a $\mathbf{P 2}$ e a P3, o que implicava constantes improvisações, com o uso do Datashow e 'aulas prontas' ou vídeos curtos, objetivando essencialmente o entretenimento dos estudantes. De novo citamos Galperin (1954 in Simon, 1957, p. 218, tradução nossa), que chama a atenção para o planejamento minucioso das etapas do processo de ensino-aprendizagem, de modo a garantir a assimilação dos conceitos. Para o autor, essas etapas são necessárias para o sucesso da aprendizagem. A construção da Base Orientadora da Ação é fundamental para que o estudante 
execute as ações mentais adequadas às operações no mundo material e não material.

As professoras não foram capazes de mencionar nenhuma evidência, no campo educacional, que fosse capaz de sustentar as suas ideias. Portanto, trata-se de uma crença construída a partir de uma representação social acerca do uso das novas tecnologias, muito possivelmente relacionada a aspectos ideológicos e mercadológicos.

Outra subcategoria que encontramos nas falas das professoras, relacionadas à $\mathbf{C 2}$, foi à crença de que determinados conteúdos seriam mais fáceis de ensinar, devido ao fato de estarem relacionados à zona de interesse do estudante, como por exemplo, questões relativas ao sistema reprodutor. Esse código foi designado como vida cotidiana imediata. Isso ocorreu, principalmente com a $\mathbf{P 2}$ e a P3. Selecionamos alguns trechos das entrevistas que evidenciam essa constatação:

P2: [...] porque eu sei que eles são adolescentes e eles gostam de falar. Só que às vezes eles falam coisas e fazem perguntas que não são tão pertinentes assim, né, a única coisa que eu sei, que são as características dos seres vivos? Sobre reprodução, que é uma coisa que eles se interessam bastante, né, que é ir não, não assim do lado científico como funciona uma mitose uma meiose, uma divisão celular. Eles querem mais com relação à reprodução humana mesmo. Como funciona, como é que é o sexo. As dúvidas vão surgindo a mil. Aí sim. Eu entendo. Eu percebi, tanto na turma do ano passado, como desse ano, já que eu não aprofundei muito no conteúdo, que eles querem saber mais. Eles estão descobrindo o corpo, tudo, eles estão começando a ter essa maturidade aí, essa, esse tipo de aula, então é, ah eu percebi que eles conseguem [está mais próximo deles, do interesse deles] sim, tá mais próximo deles [interesse deles].

P3: [...] filme, eu sempre utilizo, lá no finalzinho do ano, que daí no primeiro ano a gente sempre entra naquela parte da estrutura reprodutora. Então, como eu falo pra eles, eu vou enfatizar a estrutura reprodutora masculina, feminina, mas principalmente dar ênfase no quê? $\mathrm{Na}$ gravidez, métodos contraceptivos, doenças, aí eu sempre utilizo uma parte visual, que é um filme baseado em fatos reais. Que trata da mutilação feminina [ah]. Sempre, antes de falar, a gente, tá, eu pego algumas reportagens para estar sempre atualizada. Por mais que a gente fale assim, nós estamos vivendo 2017, isso não acontece, mas acontece. Acontece sim! E quando a gente traz 
para sala de aula, é algo que o aluno nunca imaginava que isso aí acontecia. Quando eu mostro pra eles, isto aqui é baseado em fatos reais. Uma pessoa que hoje em dia luta, né, contra essa situação, é, com relação aos direitos da mulher e aí pra eles, então eu acho que nós temos que abordar de certa maneira, assim, algo que não fique monótono. E mostro que essa situação aqui é importante, eu não conheço, então, a gente tem que saber de certa maneira como abordar [criar estratégias] isso, criar estratégias pra aula. (Transcrição de audiogravação)

A crença de que a relação com o cotidiano imediato dos alunos, especialmente em questões de sexualidade, está baseada na concepção tradicional de adolescência. Na concepção tradicional ou liberal de adolescência, o sujeito é percebido a partir da ideia de natureza humana. Essa perspectiva é biologizante. $\mathrm{O}$ entendimento é que o desenvolvimento dos adolescentes é resultado de processos naturais, pautados pela ação de hormônios, o que explicaria o interesse pela sexualidade. No caso das professoras de biologia, a P2 e a P3, notadamente, o tema esteve reduzido à fisiologia, aos aspectos essencialmente biológicos.

Com relação especificamente ao ensino da temática da reprodução, que aparece nos dois trechos anteriores, deduzimos que se trata de uma representação social do conceito clássico de adolescência, baseado em um constructo biológico, em que o comportamento do adolescente é explicado pela ação hormonal. Pensamos ser, novamente, uma situação estereotipada e parcial da realidade. Também é sinal de que as crenças e concepções que as professoras estabelecem não se separam das questões pessoais. Elas se combinam, pois provavelmente orientam as suas vivências e a atividade profissional.

Outra crença das professoras, sobretudo da $\mathbf{P 2}$ e da P3, é que os alunos não fazem um esforço para manter a atenção às aulas e, consequentemente, para aprender. Dessa constatação surgiu a subcategoria relacionada à capacidade e ao esforço dos estudantes. A subcategoria abrange as considerações dessas duas professoras em relação à disposição e ao ânimo dos estudantes em aprender. Elas foram as professoras que mais criticaram a conduta dos estudantes durante o ensino:

P2: [...] com essa turma que eu estou trabalhando, no seu caso que você está pesquisando. Eu percebi que eles são, eu não sei se eles levam mais na brincadeira. Eles ficam mais dispersos porque é assim, eu passei uma aula, por exemplo, membrana 
plasmática [...] eles ficaram muito dispersos; eles conversam muito.

P2: [...] eles não têm o hábito de anotar, de questionar e de perguntar. Se eles têm dúvida, eles vão com dúvida para casa, eu sei, e aí depois e depois as dúvidas surgem, a gente sabe, né $[\ldots]$

P2: [...] como eu falei pra você: a gente sabe que aquela turminha, que são mais participativos, eles vão ali em cima, eles olham, eles querem olhar, eles querem ficar o tempo inteiro mexendo e há outros que são bem mais apáticos. Olham de longe, não se interessam tanto nesse espírito mais investigador $[\ldots]$

P3: [...] o que realmente é pesquisa pra ele? Ah, o que a pesquisa, em si, vai proporcionar? É infelizmente, acho que ainda é algo assim, que o jovem, o aluno ainda não compreendeu como fazer um trabalho. Para ele é "pronto, eu pequei e entreguei”. Já garanti uma nota boa, vamos dizer assim, boa baseando [no recorta e cola] isso, copia e cola.

P3: [...] eu vejo que tem alunos que tem problema, há um problema, ou é dentro da escola, ou muitas vezes, não é dentro, é em casa, mas a gente observa pelo olhar. Pela atitude eles falam, mas o professor tem que chegar, mas eu não posso invadir a privacidade do meu aluno. Agora, o que que eu faço, naquele momento que a gente tá conversando. (Transcrição de audiogravação)

Nesse caso, evidenciamos que as professoras atribuem unicamente aos estudantes, a "falta de interesse" e a disposição para a aprendizagem. Em nenhum momento da entrevista elas levantam hipóteses sobre os métodos abraçados, o currículo ou as condições objetivas do trabalho pedagógico. Também não se referiram à atuação da coordenação pedagógica ou da própria direção. Retomamos aqui Saviani (2005, p. 36), que assevera que a educação é um processo de mediação de uma prática social global, sendo o ponto de chegada e de partida da prática educativa. Trazemos, na íntegra, as suas menções à mediação e às suas implicações sobre a atividade do estudante, a fim de consubstanciar a nossa posição: 
Daí decorre um método pedagógico que parte da prática social onde professor e aluno se encontram igualmente inseridos ocupando, porém, posições distintas, condição para que travem uma relação fecunda na compreensão e encaminhamento da solução dos problemas postos pela prática social, cabendo aos momentos intermediários do método identificar as questões suscitadas pela prática social (problematização), dispor os instrumentos teóricos e práticos para a sua compreensão e solução (instrumentação) e viabilizar sua incorporação como elementos integrantes da própria vida dos alunos (catarse). (SAVIANI, 2005, p. 37)

Percebemos, então, que os conteúdos estão afastados da vida prática dos estudantes. Como não são chamados a opinar na sua definição, tanto professores como alunos não se veem prestigiados. Dessa maneira, não há uma relação fecunda na compreensão e no encaminhamento dos problemas.

Nos trechos selecionados, inferimos que as professoras atribuem o sucesso ou o fracasso dos alunos às suas próprias capacidades. No caso da P2, é evidente que ela define que aprender é um caso de atitude do sujeito frente ao conhecimento. Quem quer aprender, se organiza para isso. O estudante é o responsável direto pelo seu sucesso ou fracasso. De novo prevaleceu uma das características pessoais da $\mathbf{P 3}$ para tentar compreender as dificuldades dos estudantes e relacionar ao ensino. Pelas nossas observações, é nítida a psicologização da realidade. Ela busca, em questões pessoais e emocionais, as respostas para a conduta vista como inadequada dos estudantes, em detrimento de suas realidades socioeconômicas ou do sistema educacional.

Quanto à P1, não ouvimos, em seu discurso, uma responsabilização direta aos estudantes pela conduta inadequada. Como relatamos, a P1 era a professora da T1, que era a turma com poucos estudantes repetentes. De novo, listamos uma série de fatores para explicar as concepções de P1. Uma delas é que a maioria dos estudantes da T1 era de novatos na escola. A P1 apresentava um maior cuidado no planejamento e na execução das ações de ensino. No campo profissional, a professora era a única que tinha cursado uma pós-graduação. 


\section{C3- Questões vinculadas à motivação}

Iniciamos nossa análise desse item recordando que, na Teoria das Ações Mentais por Etapas, citada ao longo do capítulo IV, a motivação constitui a etapa inicial da atividade de ensino, principalmente se se tratar de qualquer tipo de atividade nova (TALÍZINA, 2000). Para a autora, a motivação cognitiva é uma via eficaz para impulsionar o estudante à aprendizagem.

Assim, neste grupo de questões analisamos, especialmente, os aspectos afetivo-volitivos que permearam as relações das professoras com os estudantes e vice-versa. Esses aspectos estão vinculados ao encorajamento, aos estímulos e aos incentivos das professoras no tocante às atividades decorrentes do planejamento, do uso de técnicas de ensino, da avaliação, enfim, do conjunto de ações que se efetivam antes, durante e depois da atividade de ensino propriamente dita. Não somente as questões positivas, como também as negativas, conscientes ou não, mas que desencorajam ou desanimam as atividades, ações e operações voltadas ao processo de formação de conceitos.

Essa família foi a mais subjetiva, uma vez que está fundamentada nas observações do pesquisador. Porém, tanto quanto possível, traremos as falas dos estudantes e professoras, com a intenção de aclarar as inferências. A fim de analisarmos melhor esta categoria, é oportuno o resgate de Talízina (2000, p. 190, tradução nossa), que vê a motivação como componente fundamental no processo de ensino-aprendizagem, uma vez que precede à orientação para as ações pedagógicas. Segundo a autora, o desenvolvimento dos motivos da aprendizagem se dá por duas vias: a primeira, no nível de consciência dos estudantes acerca do significado social dos conhecimentos e habilidades; a segunda, através do desenvolvimento e incremento de ações que os estudantes consideram como importantes. A primeira via requer a mediação do professor; a segunda, o planejamento das ações e operações com a participação dos estudantes.

Em C3, destacamos os seguintes códigos: participação dos estudantes; responsividade da professora; clima da aula; e as demonstrações de afeto (FIGURA 10). 
Figura 10 - Rede semântica exibe a importância da motivação na dinâmica da aula.

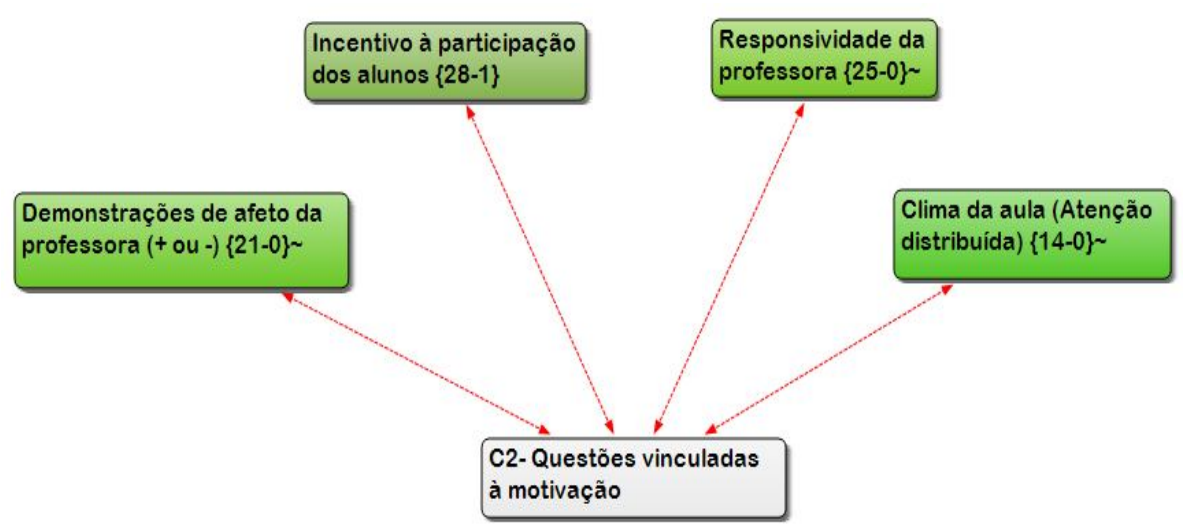

Fonte: Rede semântica produzida com apoio do software ATLAS.Ti.

Esses códigos (FIGURA 10) mostraram-se fundamentais para a atividade do ensino de conceitos. Pelas observações das aulas, evidenciamos que a motivação dos estudantes esteve intrinsicamente relacionada às características pessoais das professoras, tais como a empatia, a atividade comunicativa, a organização, a preocupação com os estudantes, a criatividade, além de diretamente vinculada à organização e ao planejamento das aulas.

No que tange ao código participação dos estudantes, analisamos as situações de cooperação e aproximação das professoras com os estudantes e as atitudes compreensivas das professoras, que se manifestaram através do apoio emocional e a bidirecionalidade na comunicação. Designamos esses aspectos de responsividade. Também analisamos a capacidade das professoras em manter a atenção aos vários estímulos durante as aulas.

Na figura 11, os códigos como o incentivo à participação dos estudantes e a responsividade da professora podem ser destacadas do conjunto dos fatores ligados à motivação pelo número de menções. $\mathrm{O}$ código do incentivo à participação dos estudantes teve $\{28\}$ destaques e a responsividade da professora, $\{25\}$. Depreendemos que esses dois fatores são fundamentais no processo de ensino-aprendizagem de conceitos.

Leontiev (1983, p. 83, tradução nossa) expõe um conceito fundamental sobre o papel do motivo no processo de ensino-aprendizagem: a atividade não pode existir sem que haja um motivo, não existe atividade que não seja motivada. 
As questões motivacionais estão ligadas aos aspectos afetivo-volitivos, vinculados às emoções e à vontade, promovendo a disposição ou a apatia do sujeito para a ação. Considerando os objetivos da instrução, esses aspectos são imprescindíveis para a efetivação da aprendizagem. Ficou evidente que a motivação dos estudantes para a atividade é um fator determinante nos processos de sustentação da atenção. Classificamos essa condição como fundamental na assimilação dos conceitos científicos.

Ainda segundo o autor, a atividade humana se dá devido a uma necessidade; não ocorre de forma indiferente a ela, mas sim devido à existência de motivos. Os motivos quase sempre estão ligados ao objeto da ação que, segundo Leontiev se tornam o seu motivo real. Nos animais, o objeto de sua ação sempre coincide com os motivos de sua ação. No caso da atividade humana, como por exemplo, o processo educacional, o objeto da atividade nem sempre é coincidente com os motivos das ações. Entendemos que isso pode se se tornar um problema, pois os estudantes, ao executarem um conjunto de ações planejadas pelo professor, nem sempre estão conscientes dos seus reais motivos.

Assim sendo, o significado sobre a atividade realizada fica separado do sentido que o estudante possui. Por vezes o estudante se pergunta: "por que devo realizar essa ou aquela atividade? Qual é o fim da atividade proposta pela professora?" Nesse caso, entra em cena um processo de alienação entre o significado e o sentido. Essa separação entre o significado da ação e o seu sentido promove o afastamento do estudante dos motivos reais das ações. O resultado é que os estudantes não se veem motivados a continuar engajados nas ações, o que produz insatisfação. Cabe ao professor promover a conscientização dos estudantes acerca dos objetivos das atividades de ensino, de modo a gerar a motivação e/ou estimulá-la.

Segundo Gonzàles-Serra (2014, p. 199), a harmonia entre a satisfação e a insatisfação favorece o equilíbrio da motivação, produzindo a motivação superior ou consciente. Para Leontiev (1961 in Longarezi \& Puentes, p. 40), as atividades dos participantes de um trabalho em conjunto são estimuladas pelo seu produto. Mesmo que o sujeito não tenha ainda a noção do conjunto da atividade e seus objetivos, as suas necessidades podem ser satisfeitas por meio dos seus resultados intermediários. Para o estudante, o resultado positivo do processo de ensino manifesta-se quando ele termina o ano letivo e recebe a aprovação para a outra 
série. No entanto, a motivação se estabelece por ocasião dos resultados intermediários durante o bimestre, como, por exemplo, os resultados parciais das avaliações. Se forem satisfatórios, ele continua motivado à ação; caso contrário, ele tende à desmotivação.

Passamos agora a analisar a subcategoria do incentivo à participação dos alunos. A P1 se esforçou para que o conteúdo fosse apresentado de forma interativa e dialogado. Por exemplo, ela repetia o enunciado e pedia aos estudantes para repetirem. Ela alterava o tom de voz para realçar certas partes dos enunciados. A intenção da professora era guiar os estudantes no trabalho com as ideias científicas e na expansão do seu uso na vida cotidiana.

Uma das questões da entrevista era se as professoras solicitavam e incentivavam a participação durante as aulas. Com referência à P1, obtivemos os seguintes relatos dos estudantes:

A1: Sim ela, porque ela, tipo, tenta fazer com que a gente participe, mas, tem uns, tem gente que participa, mas tem outros que não consegue. Não querem participar, mas, por, como fala? De todo jeito, quando ela consegue explicar, eu tenho vontade de falar, mas é a vergonha que não deixa você participar da aula ou medo de errar.

A2: Sempre. Ela não só quer que a gente participa da aula, mas ela quer, tipo, que a gente faz um debate ela vê, ela vê se a gente entendeu a matéria ou não. Se a gente não entendeu a matéria, ela explica novamente, para que a gente entenda. Mas a parte, a maioria das aula ela quer que, tipo, fosse um debate pra ver o que aprendemos.

A2: A professora tá ensinando isso de uma maneira muito boa. Além dela explicar, ela desenha, mostra a característica e pergunta se a gente entendeu ou não entendeu. Ela pergunta duas ou três vezes.

A3: Quando, tipo, quando ela acaba de explicar o conteúdo, ela sempre faz pergunta relacionada. Ela quer a sua participação, pra ver se você realmente entendeu. (Transcrição de audiogravação) 
Os relatos, demonstram que os estudantes se dão conta de que P1 solicita e incentiva a sua participação nas aulas, o que confirmamos nas observações. Atribuímos esse modo de agir às características pessoais da professora e à experiência acumulada. $\mathrm{O}$ incentivo à participação dos estudantes se deu através de questões levantadas pela professora. Essa forma de atuar facilita a manutenção do diálogo com os estudantes.

Por outro lado, vimos pouca interação da $\mathbf{P 2}$ com os alunos. Muitas vezes ela não cumprimentava os estudantes no início da aula ou sequer se despedia deles ao final. No começo das observações, a nossa percepção era de que as aulas não possuíam continuidade nos assuntos abordados. O padrão básico de interação era: a professora dava a explicação, fazia perguntas aos estudantes e fornecia as respostas ela mesma. Prevaleceu a interação monológica e de autoridade. Os alunos normalmente não eram solicitados a se posicionarem. As aulas eram essencialmente expositivas. O conteúdo do discurso da professora era descritivo dos fenômenos estudados e pouco explicativo.

Quanto à P3, também destacamos o seu empenho em manter a atenção dos alunos. Ela sempre cumprimentava os estudantes e procurava manter uma relação próxima; buscava mostrar otimismo e alegria. No princípio, parecia que ela estava desempenhando um papel, depois percebemos que era mesmo uma característica pessoal. A sua principal forma de abordagem comunicativa era o discurso não interativo e dialógico. A professora solicitava a participação dos estudantes, mas prevalecia o discurso científico e a sua opinião. $O$ seu discurso era fundamentalmente de autoridade. Muitas vezes ela conduzia os estudantes a um ponto de vista específico, utilizando a estratégia de perguntas e respostas. Geralmente as perguntas formuladas eram respondidas por ela mesma. A fim de ilustração, trazemos algumas das respostas dos estudantes em relação ao incentivo à sua participação nas aulas:

A6: Todo momento. É a todo o momento ela quer que a gente participe, quer a gente se interage com ela durante as aulas e a atividades prática e atividades escritas.

A8: Aqui na escola é a primeira vez que eu estudo. Ela solicita. Solicita a gente a participar. Essas coisas. Mas tem muitos alunos que atrapalham a aula, então eu acho que isso fica difícil. 
Por causa da situação, mas eu no máximo tento participar de alguma coisa. Eu gosto de falar, eu gosto de prestar atenção na aula então, quando ela pergunta alguma coisa, se eu sei, eu vou lá e falo; se não sei, eu fico quieto, não sou de ficar falando.

A9: Ahã. Na verdade, na maioria dos professores eu não notei incentivo dos professores talvez de uns dois, mas do dela não. (Transcrição de audiogravação)

Pelos depoimentos, percebemos que os estudantes não entendem que haja incentivo à sua participação durante a apresentação do conteúdo. Constatamos, nas observações, que existia um esforço da $\mathbf{P 3}$ em manter uma relação dialógica com os estudantes, mas também notamos a rotina de responder, ela mesma, às questões levantadas.

Em relação às atitudes compreensivas e de apoio emocional que designamos de responsividade, das três professoras analisadas, a P1 e a P3 obtiveram o maior sucesso. A P1 se destacou por sua narrativa científica, pois vez ou outra fazia perguntas aos estudantes, exaltando os fatos científicos e as constantes mudanças no tom da voz. Por vezes testemunhamos o incentivo aos estudantes em procurar as evidências científicas dos fenômenos.

Quando possível, a P3 destinava uma parte da aula para conversas informais com os estudantes. Os conteúdos desses diálogos eram de apoio emocional e de 'conselhos'. Ela foi eleita a professora 'madrinha' da turma, com a responsabilidade de abordar questões de indisciplina e outros problemas da turma frente a outros professores. Levava à turma as reclamações das professoras e da coordenação, situação em que aproveitava para manter esse diálogo com os estudantes.

Quanto ao código que nomeamos de clima da aula, do mesmo modo que na responsividade, os destaques foram a P1 e a P3. Tratamos do clima escolar positivo, uma forma de organização e condução da aula, em que os estudantes e as professoras estejam em colaboração, de modo que mantenham a atenção dos alunos às atividades propostas. A manutenção de um clima da aula positivo é um dos responsáveis pelo sucesso da aula. Em grande medida, essa competência de manter a atenção distribuída está relacionada a uma habilidade desenvolvida a 
partir das experiências profissionais das professoras e de outras vivências, além da formação inicial e continuada.

O clima de aula foi acompanhado pelas observações das aulas. No caso da P1, de uma maneira geral, os alunos estavam pouco dispersos, possivelmente pelo fato de a professora circular no tablado e focar a turma toda. Apesar da tentativa de controle da professora, havia alguns poucos (um ou dois) estudantes que dormiam, utilizavam o fone de ouvido ligado aos celulares e alguns que pareciam estar jogando. Essa situação era rara nas aulas da professora. Mesmo assim, o clima da aula era razoavelmente agradável para os alunos e a professora. O clima de aula é o resultado de todo o trabalho pedagógico: planejamento, avaliação, relação com a aprendizagem, com as técnicas de ensino, enfim, com o conjunto de atividades que se realizam antes, durante e depois da atividade de ensino propriamente dita.

Inferimos que a P1 dispunha de habilidade para manter um clima positivo na sala de aula, sem recorrer ao controle externo (orientação) ou elevar a voz. Com essa estratégia ela conseguia, por exemplo, manter a atenção dos alunos à sua narrativa. A aplicação planejada dos materiais disponíveis para o ensino e a determinação de objetivos claros, com ações e operações organizadas, provaram ser adequadas para a construção de um clima que favoreceu o ensino de conceitos.

A $\mathbf{P 2}$ chamava constantemente a atenção da turma para a manutenção do silêncio durante as aulas. Como exemplo de condução das aulas, no início do semestre não havia livros para todos os alunos, que faziam a leitura em duplas. Ela costumava fazer a leitura de pequenos trechos e depois tecer alguns comentários. Poucos alunos a acompanhavam, inclusive vários estavam sem o livro. Outros sequer traziam o livro de casa. Constatamos grande dispersão da atenção durante as aulas. Muitos estudantes estavam utilizando discretamente o celular com o fone de ouvido escondido; alguns dormiam na aula. Como não estavam claros para os estudantes os objetivos das suas ações, não havia motivos para continuar com a operação de leitura. Os estudantes executavam uma determinada operação sem ter em conta o objetivo da ação. De acordo com Leontiev (1983, p. 83, tradução nossa), o objetivo de uma ação está ligado ao seu objeto, que representa o motivo real. E é esse motivo que acaba por estimular o sujeito a se ater a uma determinada ação. No caso em tela, o clima não era favorável ao ensino e à aprendizagem. 
A P3 estabeleceu uma boa relação com os estudantes, tanto que foi eleita a madrinha da turma. Na maioria das vezes, conseguia instalar um clima de aula razoavelmente positivo para a aprendizagem. Por diversas vezes conseguia entabular uma conversa informal com os estudantes, o que favoreceu a comunicação. A P3 chamava a atenção da turma firmemente e eles prontamente atendiam à sua solicitação de silêncio. Em certas situações, quando não conseguia a atenção, chegou a recorrer à avaliação como uma forma de coação. Essa turma era composta por diversos alunos repetentes.

Outra característica que temos como relevante para a motivação foi a capacidade de demonstração de afeto. Essa disposição liga-se às vivências, à formação inicial e à experiência profissional da $\mathbf{P 3}$ e está intrinsicamente vinculada aos outros aspectos já mencionados em C4. Por vezes, antes do início da aula, a professora mantinha contato amistoso com determinados estudantes, o que revelava preocupação e manifestação de afeto. Percebemos reciprocidade dos estudantes nessas manifestações.

A demonstração de afeto pode contribuir para criar os laços afetivos entre os estudantes e a professora. A $\mathbf{P 3}$ ressaltava, notadamente ao explicar temas como reprodução humana ou preservação do meio ambiente, questões de ordem moral e ética. Embora não houvesse, necessariamente, um diálogo, havia espaço para a exposição de opiniões e sentimentos por parte dos alunos. Com essa forma de relacionamento mais amistoso, a $\mathbf{P 3}$ conseguia neutralizar situações potenciais de indisciplina e manter um clima razoável em sala de aula.

\section{C4 - Questões vinculadas ao papel do ensino médio}

Essa família, que denominamos $\mathbf{C 4}$, é uma classe de grande relevância para a nossa pesquisa, pois tem relação com a formação para o trabalho, que constitui a 'mola propulsora' do ensino. Essa família surgiu das análises das entrevistas com as professoras e os estudantes. Localizamos concordâncias em múltiplos aspectos, que deram origem a quatro subcategorias: influência da família; voltado para ensino superior; preparação para o ENEM e Vestibular; mercado de trabalho e escolha profissional. Para facilitar o entendimento, organizamos a figura a seguir (FIGURA 11): 
Figura 11 - Rede semântica representa a C4 "Questões vinculadas ao papel do ensino médio" e as referidas subcategorias vinculadas

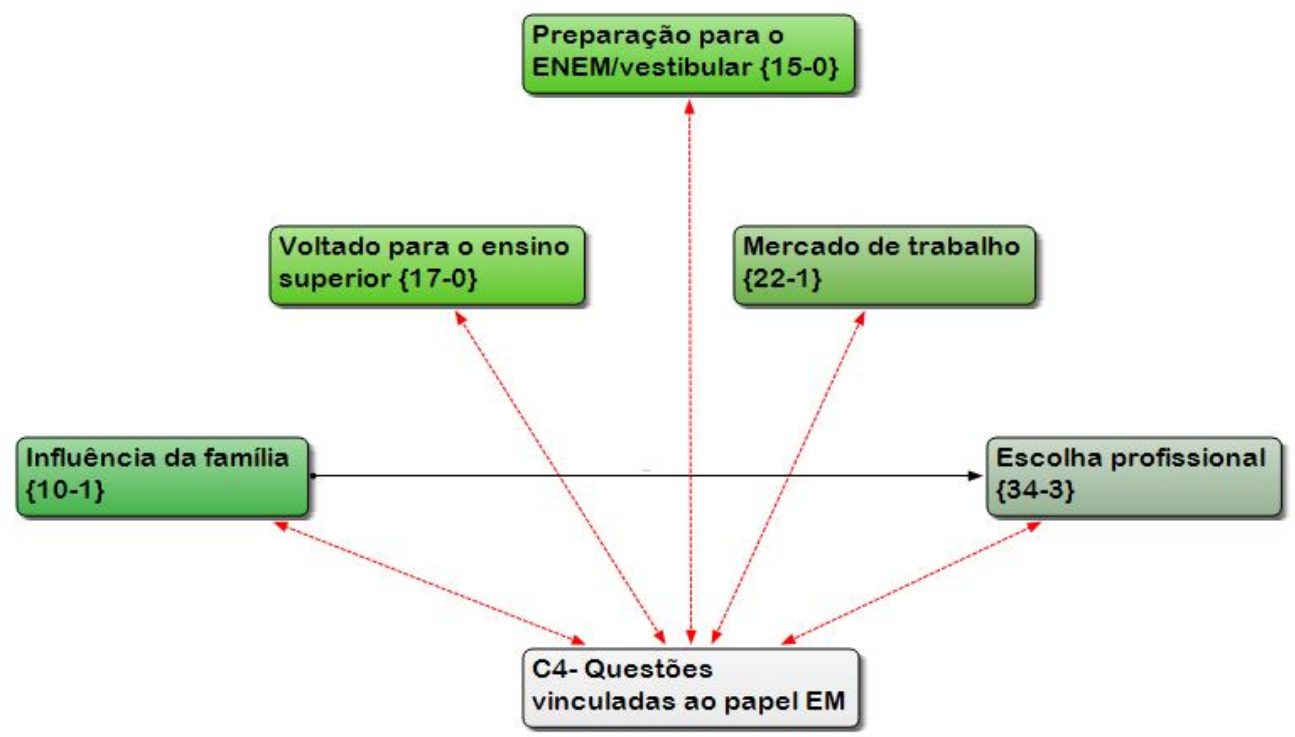

Fonte: Rede semântica produzida com apoio do software ATLAS.Ti.

Numa primeira análise da rede semântica, constatamos uma particular relação entre os códigos escolha profissional e a influência da família. Também notamos que o código escolha profissional possui uma vinculação com $\{34\}$ menções de estudantes e professoras e $\{3\}$ com outros códigos. Reparamos que a escolha profissional sofre algum tipo de influência da família. Trazemos algumas dessas citações para comprovar a relação:

A2: Eu já disse para minha mãe, quando tiver 18 anos, quando terminar o ensino médio, eu quero me alistar na marinha. Minha mãe disse que é muito bom. Minha prima é marinheira, é cabo, só que ela não para aqui, ela tá lá em Curitiba.

A3: Acho-a interessante, né porque, com base nela, a gente pode conhecer mais, mais sobre a célula, se aprofundar e, sei lá, eu sempre me inspirei pela minha irmã por ela ser bióloga.

A4: Acho que eu tenho um pouco de pressão entendeu? Tipo assim. a minha mãe é professora de história, praticamente ela requer muito de mim. Entendeu? Na matéria dela [ahã]. Eu fui me aperfeiçoando em história, fui gostando, minha mãe, como professora de história, falava muito da matéria pra mim e eu fui gostando. Mas também a professora do ano passado ajudou bastante, pois era uma professora que eu me dava bem. 
A5: Sim, ela ficou pior. No fundamental ela já cobrava, mas depois que passou para o ensino médio, tá cobrando mais, porque "só tem três anos para terminar". "Talvez sejam os três anos mais difíceis" aí depois já começa a pensar que tem o que fazer de faculdade, se vai fazer ENEM... A cobrança é bastante. (Transcrição de audiogravação)

Vemos, nesses depoimentos, que o grupo familiar exerce uma extraordinária influência na escolha profissional do estudante. O ensino médio é o nível de ensino cuja característica fundamental é a preparação para o mundo do trabalho, a constituição profissional.

Diante das condições oferecidas aos estudantes, não existe a possibilidade de uma escolha profissional genuína. A própria escola não oferta aos estudantes atividades que visem à orientação profissional devida. A escolha profissional, nesse caso, acaba no plano da fantasia e é, muitas vezes, influenciada pelo prestígio de determinadas profissões. Evidenciamos, nessa escolha profissional, a correlação com a classe social à qual o adolescente pertence.

Leal e Mascagna (in Martins, Abrantes e Facci, 2017) explanam:

\begin{abstract}
Esse processo pode se dar de diferentes maneiras, dependendo da classe social a que a/o adolescente pertença. Se o adolescente pertence às camadas sociais mais populares, a entrada no mundo do trabalho pode ocorrer ainda bastante cedo, muitas vezes, paralela aos estudos ou mesmo significando o seu abandono da educação básica antes de sua conclusão. Para as classes com maior poder aquisitivo, a adolescência pode significar um tempo maior de espera para integrar o mercado de trabalho, o que pode acontecer, em muitos casos, apenas após a conclusão do ensino superior. (LEAL; MASCAGNA, 2017, p. 225)
\end{abstract}

O modo como está organizado o ensino médio no Brasil não possibilita a escolha profissional, notadamente para os filhos da classe trabalhadora. É o mercado de trabalho que acaba por apresentar as alternativas profissionais. Muito embora o ensino médio esteja revestido da aparência da escolha livre, ele às vezes oculta as circunstâncias reais que envolvem as opções profissionais, seja na formação técnica ou no ensino superior.

Como o ensino médio, na contemporaneidade, possui um caráter essencialmente propedêutico, o foco da formação para o trabalho recai sobre o 
ensino superior, excetuando-se os cursos de formação profissional específica, como os do chamado Sistema "S" (SENAI, SESC, SESI) e os cursos de formação prática das escolas federais. No capítulo dois, vimos que no Brasil, desde 2008, existe a Rede Federal de Educação Pública, Profissional, Científica e Tecnológica, que oferece uma formação profissional aliada a uma formação mais geral. Nessas escolas, também são oferecidos cursos rápidos de formação profissional.

Observamos que as professoras vinculam a formação em nível médio à preparação para o ENEM/Vestibular. Tanto o conteúdo como as formas de avaliação são voltadas para essas provas de seleção. Porém, os estudantes filhos da burguesia costumam levar vantagem ao concorrer para uma vaga no ensino superior público, sobretudo nos cursos de maior prestígio, pois estudam em escolas mais eficientes na preparação para o ENEM/Vestibular. No Brasil, foi desenvolvida a ideologia de que a formação em nível superior é necessária para que o sujeito ascenda socialmente, o que impacta diretamente sobre o papel do ensino médio.

Com as falas de ambos os atores, professoras e estudantes, percebemos que o papel do ensino médio é preparar o estudante para o ingresso no ensino superior. Há, porém, uma diferença na maneira como os estudantes provenientes de diferentes classes veem o ensino médio. Os estudantes pertencentes às classes médias e às classes mais populares encaram o ensino médio de forma distinta. Os estudantes das classes médias veem-no como uma forma de preparação para o ingresso no ensino superior, enquanto que os das classes populares o percebem como uma forma de preparação para o mercado de trabalho. Ilustramos a questão com alguns trechos das entrevistas dos estudantes. Quando perguntamos aos estudantes pertencentes a diferentes classes o que pensam fazer depois de concluir o ensino médio, algumas das respostas foram:

Estudantes com menos recursos:

A2: No momento, eu quero fazer cursos de informática, manutenção de computadores, ou o curso pra mecânico pra mexer em partes assim e curso de gerais de eletricista, porque eu penso em me alistar na marinha. 
A7: Quero ser elétrico. Mexer como soldador. Com solda. Pensando em trabalhar que nem meu pai. Trabalhar em uma empresa agora. Trabalhar numa empresa lá da Bolívia.

Os estudantes com mais recursos:

A3: Eu pretendo chegar a uma faculdade, né. E depois de terminar a minha faculdade, eu quero me especializar e ser um bom oficial.

A4: Eu tenho paixão por animais, eu pretendo ser veterinário, mas antes vou estudar, prestar vestibular, vou dar uma descansada, vou correr mais a minha vida pessoal, casa, família, namoro, aí eu vou ingressar numa profissão.

A5: Depois que eu terminar o ensino médio, eu vou fazer o Enem. Eu vou mudar de cidade, vou fazer faculdade e vou cursar. Mas o que eu quero que é ser antropóloga forense e trabalhar.

A6: Eu sempre gostei de balé! Eu sempre quis viajar. Fazer curso. Mas também eu gosto da psiquiatria. Então, tipo assim, eu quero ser psiquiatra eu quero fazer a faculdade de psiquiatria e sem deixar de lado o balé. Acho que porque acho que a dança e a psicologia psiquiatria andam junto, porque uma pessoa que tem problemas pessoais, ela dançando fazendo qualquer tipo de arte. Acho que ela acaba se liberando um pouco mais, largando de lado os problemas e se libertando na dança ou no teatro se expressando mais, então eu acho que os três caminham juntos, eu quero fazer faculdade de psiquiatria ou de dança. (Transcrição de audiogravação)

Às professoras também foi perguntado sobre o papel do ensino

médio:

P1. É mais inserir ele no mercado de trabalho, preparar ele para o mercado de trabalho, né? Mas é claro, também, que assim, eu preparo as minhas aulas com o objetivo de preparar ele também pra fazer uma boa prova no Enem [ahã], pra ele fazer uma boa faculdade, ele poder trabalhar, preparar ele pra ir pro mercado de trabalho, arrumar um emprego, começar a valorizar as suas atividades, mas também começar a estudar e ser um profissional, né? Então as minhas aulas eu preparo com este objetivo também, né? Pra preparar ele pro Enem, né? 
Por isso que nas minhas aulas eu foco nos conceitos principais que o Enem pode cobrar, e eu já senti feedback com isso também, que nem ano passado, ano passado, muitos estudantes do segundo ano: "professora, olha o que a senhora explicou de plantas, caiu esse daqui". E o gabarito não tinha nem saído, eles já sabiam a resposta da questão.

P2. Ensino médio, o que é? [o ensino médio pra você] Acho que vem a preparação para o ensino superior, só a que a gente sabe que não é bem assim que funciona, né. Porque 'ene' fatores, você não consegue dar uma aula de qualidade. Às vezes você se prepara, mas não tá ali a contento, nem o seu melhor, nem o melhor dos estudantes, a gente não pode colocar a culpa só neles. Porque é o que eu falo pra eles, a gente tem que pegar e puxar essa responsabilidade um pouquinho pra nós, meio individual. Então é tempo, horário, como é uma coisa que já ficou, o sistema é assim, né?

E vamos dizer assim, já tem essa prática, né [organização], essa organização de todos os conteúdos são dados daquela forma, então o referencial a gente tem que tá seguindo e pra vê, pra gente preparar realmente eles pru, pra, pra fazer ((hesitação)) uma faculdade, a gente sabe que não é bem assim, né, a maioria vai ficar com esse ensino médio. Às vezes nem termina esse ensino médio.

É mais para o mercado de trabalho mesmo, né? Mais pra ver se consegue um trabalho no comércio ou em alguma coisa que seja mais compatível com a realidade de cada um deles, né? Porque não são todos que vão pra universidade, então a gente, eu penso assim. A gente tem que tentar fazer, dar uma aula que, não só para preparar aquele estudante pro vestibular é pro vestibular, é, mas pra também pra é, aí já entra essa relação que a gente tem que mostrar pra eles, que eles precisam ter responsabilidade, porque não só pra uma faculdade, mas pro mercado de trabalho.

Quando eles começarem a trabalhar, eles vão ter prazo pra cumprir, né, a gente sabe, [ahã] a gente sabe que a gente precisa ter prazo. Olha que eu lembrei da sua aula, que foi isso, não sei o que, era sobre fisiologia de plantas, inclusive a questão, né, é mais isso, é preparar ele pru, pra essa, né? pro Enem, pro mercado de trabalho [legal].

P3. Além de, vamos como exemplo, eu observo da seguinte maneira, vamos trabalhar o ensino médio para, focado para o ENEM ou focado para a universidade. Huum não é o que deveria somente ser, né, teria que ser de uma maneira geral. Além de eu acho assim, além da universidade, hoje em dia tem estudantes que estão migrando mais, não tão migrando só pra universidade. Tão migrando para cursos técnicos [ahã], que na 
maioria das vezes é esquecido, então, é uma abordagem de uma maneira geral, né?

Vamos dizer assim, mas ele também, no curso técnico, ele precisar do conceito, maior, mas a gente só visa, a gente só fala, é, na parte vimos, dizer assim, na parte, vamos dizer assim, universitária. Mas acho que tem que abordar de toda maneira, deveria, realmente. Tem que ser abordado, pra tudo mas o que acontece é que, na maioria vezes, não é pego esse foco, pra começar.

O próprio trabalho, se realmente a gente tá focando o estudante para a universidade, então nós já temos que fazer um trabalho com a universidade. Se eu tenho que fazer um trabalho, eu tenho que seguir normas, eu tenho que seguir regras, porque, quando ele, o meu estudante, chegar na universidade, ele vai seguir esta norma, ele vai seguir essa regra.

Então, se realmente, nosso ensino médio, nós estamos trabalhando para formar o estudante para ir para a universidade, então nós temos que trazer um pouco de metodologia da universidade para dentro da escola daí, porque chega lá na universidade, o que a acontece [você acha que isso não acontece] na maioria das vezes, não acontece. (Transcrição de audiogravação)

Existem duas escolas dentro de uma, como verificamos. Uma que se dirige à formação integral do sujeito e outra que tende à formação de uma classe de trabalhadores, subordinada à primeira. Mas a pergunta continua. Temos duas escolas? A quem interessa ter essas duas escolas? Há uma escola para a classe dominante e outra voltada para a classe trabalhadora? De onde provém o discurso de que aqueles sujeitos mais bem 'preparados' devem ascender a uma educação superior, enquanto que aqueles 'menos preparados' devem se conformar com a situação em que se encontram?

Compartilhamos da ideia de Mészáros (2002, p. 44), de que a educação, em seu sentido mais amplo, cumpre o papel de legitimar a posição dos indivíduos na hierarquia social, juntamente com suas expectativas 'adequadas' e as formas de conduta 'certas', mais ou menos explicitadas.

Como expusemos na introdução deste texto, a educação tanto pode ser vista como uma forma de romper com a lógica do acúmulo de capital, como também como forma de manutenção da sua lógica. A escola não é somente reprodutora do capital, mas é também o lugar privilegiado de resistência ao seu avanço. Concordamos com Mészáros (2014, p. 27): "se quisermos contemplar a 
criação de uma alternativa educacional significativamente diferente, devemos lutar para romper com a lógica do capital". O capital a tudo subordina, especialmente a educação, que é o lócus privilegiado onde são também produzidas e reproduzidas as ideologias voltadas à sua sustentação.

Para Mészáros:

O papel da educação é soberano, tanto para a elaboração de estratégias apropriadas e adequadas para mudar as condições objetivas de reprodução, como para a automudança consciente dos indivíduos chamados a concretizar a criação de uma ordem social metabólica diferente. (MÉSZAROS, 2014, p. 65)

O autor confere uma nova tarefa histórica de mudanças objetivas de reprodução da sociedade, visando a reconquistar o controle total do próprio capital e a transformação progressiva da consciência. Ainda sobre a função da educação formal, Mészáros (2014) ${ }^{94}$ advoga que uma de suas funções principais é produzir tanta conformidade ou 'consenso' quanto for capaz, a partir de dentro e por meio dos seus próprios limites institucionalizados e legalmente sancionados.

Para o autor, romper com essa lógica é tarefa importante para que a humanidade continue a existir. As soluções não podem ser formais; elas devem ser essenciais. Com isso, ele quer dizer que elas devem abarcar a totalidade das práticas educacionais da sociedade. A solução formal, mesmo que sacramentada pela lei, pode ser completamente invertida, desde que a lógica do movimento do capital se mantenha intacta.

No discurso das professoras e dos estudantes, averiguamos que há um sistema de conformidades, inseridas na escola, que visam à manutenção das ideologias de classe. A alternativa de rompimento dessa lógica é que a escola e a educação devem estar orientadas a ir além do capital e romper com o discurso de que somente determinada classe social deve ascender aos níveis mais altos de formação e que as classes menos privilegiadas devem se contentar com uma formação prática.

\footnotetext{
${ }^{94}$ Ibid, p. 45
} 


\section{C5 - Questões vinculadas à avaliação}

O último tópico da nossa análise abarca as questões da avaliação. Segundo a teoria histórico-cultural, ao se tratar de avaliação da aprendizagem de conceitos, é indispensável resgatar a concepção de aprendizagem e desenvolvimento, que apresenta uma relação dialética. A premissa vigotskiana é de que o desenvolvimento é causa da aprendizagem. Para o autor, há dois níveis de desenvolvimento, o real (imediato) e o iminente (potencial ou proximal).

O desenvolvimento real pode ser medido através de testes ou avaliações, pois é o que o estudante já sabe até o momento, enquanto que o nível iminente não pode ser medido por esses testes, pois está em vias de se concretizar, e só é possível com a ajuda do professor ou de outro sujeito mais desenvolvido. Foi com base nessas premissas que emergiu a família C5.

A família C5 foi desmembrada em quatro códigos: concepção de avaliação; instrumentos de avaliação; estratégias de preparação para avaliação; função somativa (classificatória). As concepções de avaliação, tanto dos professores quanto dos estudantes, são oriundas das compreensões do processo ensino-aprendizagem. Essa família e seus códigos estão ordenadas na figura 12.

Figura 12 - Rede semântica formada a partir de C4 "Questões vinculadas à avaliação"

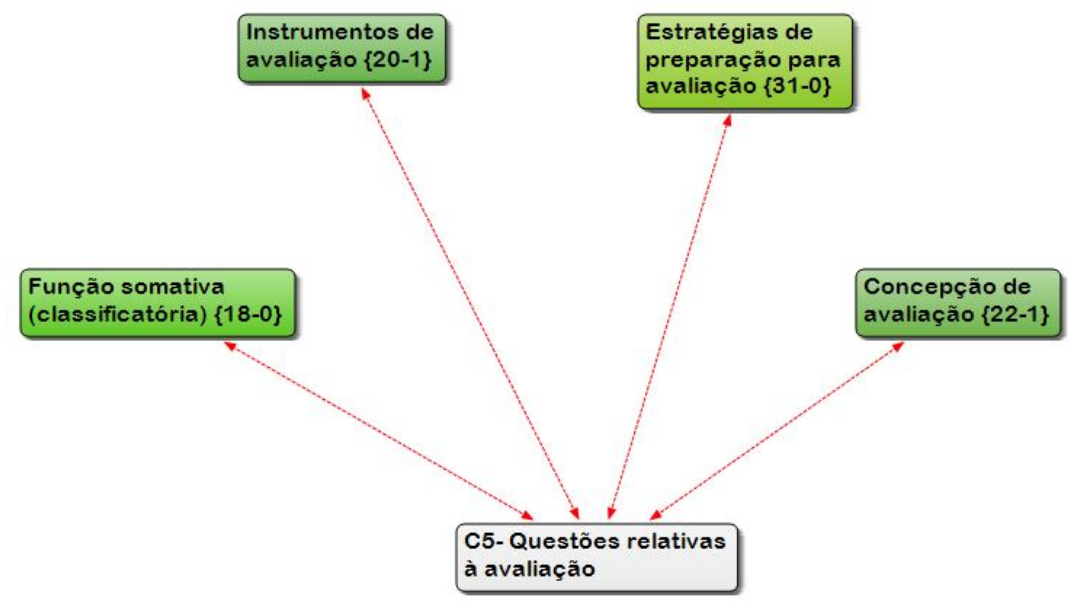

Fonte: Rede semântica produzida com apoio do software ATLAS.Ti. 
Segundo Talízina (2000, p. 157), a etapa de controle é inseparável do processo de ensino-aprendizagem, pois leva professores e estudantes à compreensão do estágio em que o sujeito se encontra, além de permitir que se façam os ajustes necessários para a consecução dos objetivos propostos através das ações. As professoras utilizam, especificamente, a avaliação com o objetivo de produzir 'nota' e classificar os estudantes.

Talízina (2000) ${ }^{95}$ divide o controle em: prévio, quando se efetiva antes da introdução de um novo conhecimento; corrente, também chamado de aferição de retorno, para verificar a eficácia e o controle sistemático das ações educativas enquanto elas ocorrem; e controle final, que possui uma função mais classificatória. Segundo a autora, a aferição das ações influi na motivação dos estudantes de duas maneiras: se a ação foi organizada de forma correta, ela aumenta a ação e a possibilidade de sucesso, promovendo a assimilação do conceito, caso contrário, diminui. As avaliações de controle prévio, corrente e final são indispensáveis para que professores e estudantes acompanhem o desenrolar do processo de ensino-aprendizagem, seja redirecionando as atividades ou repensando as estratégias, de modo que ninguém fique para trás.

No entanto, em nossas observações e das entrevistas, percebemos que a função básica da avaliação escolar é meramente uma coleta de dados de aprendizagem de certos conceitos, além de desempenhar uma função meramente de controle do comportamento inadequado. Essa forma de avaliação ocorreu, principalmente, por $\mathbf{P 2}$ e P3, que aplicavam a avaliação ao final do bimestre. Ao serem questionadas sobre os principais instrumentos de avaliação dos conceitos, as professoras responderam:

P1: Eu trabalho assim, eu alcanço assim vários tipos de avaliação, a primeira, são questões discursivas, né? Que eu explico o conteúdo, bom, eu não sei se é isso a resposta, mas, primeiro vou falar o que eu trabalho, né, que são as questões discursivas. Eu explico o conteúdo, passo aquelas questões, né? Como se fosse fixação do conteúdo. Logo após os conceitos, ele precisa reescrever o que ele entendeu [ahã]. A outra atividade é o caderno de desenho. A biologia tem, biologia e ciências têm muito desenho, têm muito, muitos esquemas. É importante ele fazer, porque fixa melhor e eu já escutei muito aluno falando "como é bom"! Até de aluno que não é mais meu, que tá no terceiro ano, lembra até hoje "eu lembro até hoje do caderno de desenho, aquele desenho tal, que eu fiz" e não esquece o conceito. Esse é outro método muito importante, o outro, é a

\footnotetext{
${ }^{95}$ Ibid, p. $157-158$.
} 
própria prova, que são questões objetivas, que eu falo assim que é de 10 a 20 questões objetivas, contendo, né, o conceito dos capítulos, dependendo da quantidade de capítulos que é pra aquela prova. Eu acho, assim, eu acho que todos sãos importantes porque nem todo aluno é igual. Pra conseguir fixar aquele conteúdo, né, e o que acontece, é que nem, tem alunos que fazem a prova objetiva e falam "eu não me dou bem na prova objetiva" e acaba ficando para recuperação e a prova de recuperação é discursiva, e ele consegue alcançar nota na discursiva. Eu vejo assim, todo esse método que eu uso alcança melhor o aluno, desenvolve o que ele aprendeu, não que só, que a, objetiva é mais importante, mas, eu acho interessante que prepara ele pro Enem. Enem é tudo objetivo, concurso é todas objetivas, né? Então isso, eu acho, importante essa prova objetiva pra eles, né? [entendi] é isso? [estou satisfeito pesquisador].

P2: Na prova, especificamente. Eu, particularmente, prefiro mesclar. Eu pego algumas questões de vestibular, as do ENEM eu já não prefiro muito, porque eu acho que as questões do ENEM são bem maiores. Então, como eles estão no primeiro ano, eles vêm muito naquele, naquela de, não falando mal do ensino fundamental. Mas eles têm aquela coisa de "a pergunta tá aqui" ou "eu quero achar a resposta do texto aqui por exemplo". O conceito. É defina vida. E vida é isso e aquilo. Então, eles têm esse hábito, de perguntar para a professora, onde que está aqui no texto? Eu falo. Gente! Eu estou tentando criar isso neles de fazer uma leitura e interpretar aquilo que eles estão lendo, porque eles querem pegar a resposta pronta. Vida, a definição de vida. Eu tento colocar uma palavra diferente, em vez de colocar defina, caracterize, enuncie, alguma coisa desse tipo, pra eles poderem entender e começar a mesclar com algumas questões. Não são todas as questões, é lógico que dá pra colocar de vestibular. Eu procuro colocar o máximo assim, questões de vestibular. Para eles poderem entender na hora da prova. Eles falam assim, essa questão está tão difícil. Gente! Leiam a questão! Aí eu leio com eles. Ó, presta atenção, é isso e aquilo, isso aqui é o que? É isso, professora, ah, então tá! Então é isso que vai ser a resposta, só isso? Só isso? Então, tento mostrar para eles que só através da interpretação daquele trechinho a gente consegue responder com aquele conhecimento que eles têm. [Então você trabalha com a intepretação pesquisador] interpretação [ajudando eles - pequisador]. Acho que é isso que estou começando a trabalhar com eles, essa interpretação, pra eles poderem interpretar, realmente aquele enunciado ali. Para eles responderem, porque eu, às vezes eles sabem, mas eles não sabem que eles sabem. Porque eles leem ali. Para eles, é um bicho de sete cabeças. Vamos dizer assim. Eles têm preguiça de ter aquele pensamento. Pensar no conhecimento. Pensar aquela coisa, eu quero tudo "mastigadinho". Eu quero achar aqui no texto. Eu falo pra eles ó, dá uma lidinha nessa parte aqui. Ah, professora! Dá uma lida. Dou uma lida, aí que eles entendem. Começam a esclarecer. Eu 
estou começando a trabalhar, agora no segundo bimestre eu vou pegar bem mais pesado na interpretação mesmo.

P3: A principal que nós temos que basear, é a avaliação. Vamos dizer assim. Não é uma avaliação. Existe a avaliação contínua. Né? Que seria a participação do aluno, o interesse dele em como tá, como ele tá sendo, como ele tá abordando o conteúdo em si, e as atividades. Até mesmo o fato da presença do livro. Então, eles têm o livro deles. A gente vê que tem alguns alunos que dizem "ah eu não trouxe", ou está sempre lá, ou praticamente, cotidianamente não está trazendo, e aí já atrapalha. Já prejudica o aluno também. Mas a avaliação principal, um método avaliativo é ainda a avaliação escrita. Abordada após o término do conteúdo. Porque, querendo ou não, a gente tem que ter algo comprovado. Escrito e feito, né. Para que eu tenha base realmente do conhecimento deles. Vamos colocar como exemplo, a avaliação escrita individual. Eu tenho certeza da abordagem do conteúdo do meu aluno agora. Usar trabalho. Eu já não sou muito de pedir trabalho. Da vez passada, eu passei um de experiência, ou seja, algo que realmente eles teriam que fazer. Se for um trabalho, uma pesquisa, eu não vejo ali. O aluno realmente. "É maravilhoso, ele é brilhante, por que é só copia e cola". Porque eu já observo perante as outras disciplinas. Que na maioria das vezes, o aluno está fazendo trabalho de outro professor. Então eu já observo. E ele tá fazendo daquele jeito com outra disciplina ele vai fazer com a minha. Ele tá entendendo algo ali. Ele tá entendendo a pesquisa é isso. Ele tá entendendo o que é ser aluno pesquisador? Ah! Eu acho que é uma metodologia que a gente precisa abordar ainda, não é mesmo? Precisa, acho que fazer com que esse aluno entenda o que realmente é a pesquisa. Pra ele, ah! O que é a pesquisa em si? Vai proporcionar, infelizmente, acho que ainda é algo assim, que o jovem o aluno ainda não compreendeu. Vou fazer um trabalho, pronto, eu pequei e entreguei. Já garantiu uma nota. Vamos dizer uma nota boa. Baseado no recorta e cola. (Transcrição de audiogravação)

Nesses depoimentos, temos que a P1 foi quem demonstrou o maior cuidado com o processo de avaliação, utilizando uma variedade de atividades e instrumentos. No entanto, a avaliação considerada principal foi aplicada ao final do bimestre, depois da apresentação e análise de inúmeros conceitos. Essa professora foi a única a utilizar o caderno de desenho como forma de avaliação. Geralmente, ela solicitava que os estudantes desenhassem em suas casas, as estruturas biológicas, objeto de estudo da aula. Esse processo ocorria em quase todas as aulas. Vez ou outra, a professora ditava ao final da aula uma questão que ela trazia de casa, ou solicitava que os estudantes respondessem às questões ao 
final do livro texto. Ao final de cada bimestre, ela solicitava que os estudantes mostrassem os vistos dados por ela.

Averiguamos que a avaliação era utilizada principalmente como forma de medir o desempenho dos alunos, mas também na forma processual ou corrente. Ressaltamos uma questão de ordem objetiva, que era a inexistência de máquinas fotocopiadoras na escola, o que dificultava a impressão das avaliações pelas professoras. Chegamos a presenciar a arrecadação de recursos pelos alunos para as cópias das avaliações. No entanto, devido ao constrangimento com a presença do pesquisador, o dinheiro arrecadado foi devolvido. Assim, conseguimos perceber o quanto as questões objetivas influenciam no processo ensinoaprendizagem. Questões básicas a serem superadas.

Em relação à citada prova de recuperação que a professora disse ser 'discursiva', ela fez revisão do conteúdo para a prova, enfatizando a etimologia dos conceitos e repetindo-os à exaustão. Sempre perguntando "é fácil?", “entenderam?", "não é difícil”. Percebemos certo encorajamento da professora em relação à avaliação, como uma espécie de 'reforço positivo'. No dia da avaliação, ela organizou as filas, disse que a prova seria objetiva e que as questões eram quase todas de múltipla escolha. Ela fez a leitura de cada questão para os alunos e deu pequenas dicas da resposta.

No caso da P2, os instrumentos utilizados foram avaliações escritas, divididas em prova mensal e bimestral. A avaliação foi ditada pela professora, o que demorou cerca de $25 \mathrm{~min}$. Os alunos tiveram cerca de $20 \mathrm{~min}$ para responder. A avaliação continha quatro questões abertas, uma questão de múltipla escolha e uma questão que pedia a relação entre colunas. Os alunos perderam muito tempo copiando a prova. Ela fez a leitura das questões e direcionou os alunos para a resposta correta. Durante o acompanhamento das aulas, algumas vezes ela utilizou as avaliações como forma de coerção para conseguir atenção e o silêncio da turma. Repetia bastante as expressões "cuidado, vai cair na prova", "presta atenção!" etc.

Evidentemente que se tratava de avaliações somativas, com a função classificatória ou de controle final, cuja função é a verificação e não a avaliação da aprendizagem (LUCKESI, 1994, p. 35). Não tivemos acesso à avaliação e nem ao seu resultado, mas no dia da entrega observamos que não havia sido satisfatório, pelo burburinho dos estudantes e a fala da professora, que cobrava 
mais empenho e melhora no 'mal' comportamento. Como não existia uma regra sobre a avaliação de recuperação, cada professora decidia em que momento aplicaria a 'prova' de recuperação. Destacamos a referência que a professora, explicitamente, fazia ao ENEM e ao vestibular na confecção das avaliações, o que nos permite inferir que existe uma ligação entre a função atribuída ao ensino médio, que é de preparar o estudante para o ensino superior.

No caso da P3, uma das formas de acompanhamento da aprendizagem era dando vistas nos cadernos dos estudantes, indo a cada carteira. Por diversos momentos a professora se referia à prova e ao conselho de classe, com o objetivo claro de coação. Isso acontecia principalmente nos momentos em que os alunos estavam agitados. Por vezes ela se referia à nota, reprovação e repetência como forma de chamar a atenção dos alunos para o que ela estava ensinando. A professora aplicou as duas avaliações programadas, sendo a prova mensal no meio e a prova bimestral, no término do bimestre. Como os alunos não tiveram um bom desempenho na primeira prova, ela propôs uma prova de recuperação. Mas disse que "não era obrigação a recuperação e que não ia fazer sempre".

Concluímos que essas diversas compreensões de avaliação estão relacionadas às concepções sobre o papel da educação. Fundamentalmente, a atividade de avaliação tem o papel de medir o desempenho dos estudantes, com a função classificatória. Através dela, os professores categorizam os estudantes como aptos ou inaptos, estudiosos e não estudiosos, os mais inteligentes e os pouco inteligentes, concluindo se podem ou não ser mantidos no processo. Retomando Luckesi (1994, p. 92), a escola opera muito mais com a verificação do que com a avaliação da aprendizagem. Para o autor, o ato de verificar "congela o objeto", enquanto que a avaliação o coloca numa trilha dinâmica, constituindo um excelente mecanismo subsidiário da ação. Os resultados da avaliação da aprendizagem permitem repensar o próprio ato de ensinar e aprender.

A fim de apreender a opinião dos estudantes sobre a avaliação das professoras, fizemos duas perguntas sobre o que achavam da avaliação da professora e se estava adequada às aulas. Algumas das respostas exemplificam as suas visões: 
A3: Sim. Tudo o que ela explicou pra gente tá ali, naquela avaliação dela. A avaliação não fica muito diferente do conteúdo, né? [fica assim]

A5: Às vezes parece um bicho de sete cabeças, sim. Ela tenta buscar, ela coloca tudo que ela nos ensina. Porém, a gente não é que não sabe ((fala devagar)). Mas ela coloca tudo que ela ensina. É adequada ao que ela nos ensina.

A7: É adequado. É adequado, porque a gente pode fazer, por exemplo, a múltipla escolha, a manuscrita e às vezes ela faz assim, tipo mandar fazer redação. Assim, fazer o que a gente entende. Resumos. O exame poderia fazer oral. Porque eu já fiz isso uma vez. Fazia várias vezes na escola que eu estudava, fazia várias vezes para prova oral de ciências e tinha que estudar.

\begin{abstract}
A8: Ah, sim! Ela passa as questões do ENEM. Eu acho que avaliação dela, em questão disso é boa. Porque a gente precisa de treinamento pro ENEM. Questões do ENEM passadas na prova são ótimas. Só que é tudo questão do ENEM. Acho que devia ser um pouco só é discursiva, porque ajuda mais. Eu gosto de escrever mais, explicar também, e pra mim seria melhor se ela passasse mais discursiva. (Transcrição de audiogravação)
\end{abstract}

Procedendo à análise desses trechos, os alunos conceberam as avaliações das professoras como adequadas. O sentido do 'adequado' foi distinto. O estudante A3 da P1 considerou o 'adequado', em relação à presença do conteúdo ministrado na avaliação. O estudante A5 da P2 também entendeu que o que a professora ensinou estava na avaliação. Demonstrou ter dificuldades, porém não chegou a culpabilizar a professora. Já A7 da P3 disse que a professora poderia variar a forma de avaliação, com questões orais. O estudante A8, também da P3, opinou que a inclusão de questões conforme o ENEM era apropriada, como uma forma de treinamento e destacou a sua predileção por questões discursivas.

Os estudantes não são solicitados a opinar sobre o tipo de avaliação a ser aplicado. São as professoras que determinam o tipo de avaliação mais adequada. Segundo Luckesi (1994, p. 42), a prática da avaliação nas pedagogias preocupadas com a transformação deve estar atenta aos modos de superação do autoritarismo e 
ao estabelecimento da autonomia do educando, pois o novo modelo social exige a participação democrática de todos. O objetivo da participação é que professor e alunos cheguem juntos a um entendimento da situação de aprendizagem que, por sua vez, está articulada com o processo de ensino.

Na mesma direção, Talízina (2000, p. 192) enfatiza que, para que o estudante esteja motivado para a atividade, é preciso que o objetivo estabelecido pelo professor também seja o mesmo estabelecido pelo estudante. Para que os objetivos sejam convertidos em motivos-objetivos, é de especial relevância a consciência do estudante dos seus próprios êxitos e de seu movimento direcionado ao futuro, ao atingimento das metas. Relembrando, toda atividade humana é atividade direcionado a um fim.

Também observamos que a avaliação é utilizada como forma de coerção aos estudantes, para controlar os seus comportamentos. O comportamento é regulado pela 'prova'. Ocasionalmente, as professoras lembravam aos estudantes que o conteúdo ensinado seria cobrado em 'provas'. Outra função da avaliação é a consolidação dos conteúdos e conceitos que poderão ser cobrados nas avaliações de acesso ao ensino superior, como o ENEM e o vestibular.

Vigotski (2001, p. 351) entende que o desenvolvimento dos conceitos científicos pressupõe certo nível de elevação dos espontâneos, no qual a tomada de consciência e a arbitrariedade se manifestam na Zona de Desenvolvimento Iminente. Fato é que os conceitos científicos transformam e elevam ao nível superior os espontâneos, concretizando a Zona de Desenvolvimento Iminente. Assim, o que o sujeito hoje é capaz de fazer em colaboração, amanhã estará em condições de fazer sozinho.

Concluímos, então, que a aprendizagem conduz ao desenvolvimento. Ela é a fonte de desenvolvimento mental dos seres humanos. Quando corretamente organizada, cria as Zonas de Desenvolvimento Iminente, que é onde os professores devem agir, de modo a impulsionar as neoformações. Concordamos com Vigotski (2001) ${ }^{96}$, que considera que os processos de desenvolvimento não coincidem com a aprendizagem, mas que ela, ao se adiantar ao desenvolvimento, produz a Zona de Desenvolvimento Iminente. Nesse caso, a aprendizagem e o desenvolvimento são processos dinâmicos e inter-relacionados.

\footnotetext{
${ }^{96}$ Ibid, p. 486.
} 
A avaliação de desempenho, então, só tem condições de apontar aquilo que o estudante já sabe. Este tipo de avaliação foi a mais utilizada pelas professoras. É claro que é necessário saber o que já foi aprendido. No entanto, a maior contribuição do professor, segundo a psicologia histórico-cultural, é atuar na Zona de Desenvolvimento Iminente e, assim, promover o desenvolvimento.

Finalizamos com Libâneo (1990, p. 2000), que frisa que a avaliação tem como função primordial acompanhar, pari passu, o processo de ensino aprendizagem. Os resultados obtidos no decorrer do trabalho conjunto dos professores e dos alunos são comparados com os objetivos propostos, a fim de constatar os progressos e as dificuldades e reorientar o trabalho. A avaliação deveria ser um processo de tomada de consciência dos erros e acertos do processo ensino-aprendizagem, que permitiria a análise das ações e operações realizadas pelos estudantes em sua atividade de estudo. Para o professor, serviria para análise de sua atividade de ensino. 


\section{6 Considerações finais}

A questão central que norteou esta tese foi compreender de que modo o entendimento sobre o processo de formação de conceitos científicos possibilita ao professor um ensino efetivo e qualitativamente superior? Assim, o objetivo da pesquisa foi compreender como se dá o processo de formação de conceitos científicos, especificamente no ambiente de uma sala de aula, acompanhando e analisando diversas sequências didáticas. Desse modo, comprometemo-nos a examinar a formação dos conceitos científicos, fundamentado na Teoria Histórico-cultural de Vigotski e na Teoria Geral da Atividade de A. N. Leontiev, como instrumento teórico-metodológico para apreender o processo de formação de conceitos in situ. Partimos da hipótese segundo a qual a categoria 'atividade' tem elementos suficientes para orientar um enfoque diferenciado acerca do processo ensino-aprendizagem.

Conforme revelado por Vigotski, o ser humano possui uma segunda natureza, que é de caráter histórico-cultural, produzida em decorrência dos processos de aprendizagem. Essa segunda condição só é viável pela mediação do outro, em condições concretas de vida e da educação. Trata-se, pois, de um processo eminentemente cultural e relacional, em que o indivíduo internaliza a realidade que é refletida na sua consciência, representando-a de modo especial e, assim, apropria-se das capacidades especificamente humanas.

Uma dessas capacidades é trabalhar no plano abstrato, tornando-se indispensável a formulação de conceitos sobre as coisas e a realidade, tendo por base a linguagem. É um ato complexo e dinâmico, construído pelo sujeito a partir de um sistema de atividades realizadas por intermédio de sua inserção na cultura, mediado pelas relações que estabelece com outros seres humanos. É nesse meio de aprendizados especificamente formais que o sujeito constrói os conceitos científicos e se desenvolve.

Essa capacidade de generalização da realidade envolve um nível elevado de abstração que só ocorre na adolescência, muito embora seja um processo que tem sua gênese na atividade objetal, ainda na primeira infância. Assim sendo, esse foi o principal motivo que nos levou a eleger o ensino médio para este estudo, 
uma vez que havia a segurança de que a maioria dos estudantes se encontrava nessa etapa da vida.

Compreendemos que a articulação entre a atividade de ensino e o estudo foi substancial para a construção dos conceitos. No entanto, através desta pesquisa, percebemos que, por vezes, o ensino e a aprendizagem estão apartados. Acreditamos que essa insuficiência de articulação entre ensino e aprendizagem esteja ligada às concepções das professoras, construídas em seus cursos de formação inicial e/ou continuada que não refletem adequadamente sobre a conexão. Constatamos que, no contexto desta pesquisa, os conceitos científicos foram comumente apresentados de modo descontextualizado e a-histórico, com o objetivo principal de preparar os estudantes para as provas que abrem as portas ao ensino superior (ENEM/Vestibular).

O ensino de conceitos é possível e imprescindível para o desenvolvimento do psiquismo. No entanto, a concepção de que eles podem ser ensinados através da simples apresentação e repetição, conforme constatado na empiria, contradiz com a teoria que nos fundamentou. A formação de conceitos constitui um longo processo, que se inicia com os conceitos cotidianos até a formação dos verdadeiros conceitos.

Para que esse processo se dê, é essencial que as condições objetivas e subjetivas estejam disponíveis aos professores e estudantes. Entendemos por condições objetivas as condições materiais, como salas de aulas adequadas; existência de laboratórios; de bibliotecas; salas com acesso à internet; refeitório; teatro e anfiteatro; salários adequados aos professores, etc. As condições subjetivas são a formação inicial dos professores e os investimentos na formação continuada, entre outras.

Também demonstramos que a Teoria da Atividade de Leontiev mostrou-se apropriada para desvelar como se dá a atividade de ensino-aprendizagem, trazendo à tona elementos que, em nosso entendimento, contribuem para a sua eficácia. Compreendemos que, tanto a atividade de ensino quanto a de estudo podem se beneficiar com essa metodologia, pois ela pressupõe a análise da atividade pelo desdobramento em ações e operações por parte dos professores e estudantes. Com base na teoria da atividade, desmembramos as atividades de ensino-aprendizagem e estudamos as suas manifestações. 
Galperin (1969 in Shuare, 1987, tradução nossa) foi citado porque enfatiza a existência de unidade indissociável entre a atividade e a estruturação do psiquismo. Para o autor, é de suma importância que os professores compreendam os processos de mediação, construção e interiorização dos conceitos. Competelhes oferecer as orientações aos estudantes de maneira que se eliminem os erros e se ensinem as propriedades da ação. O objetivo do procedimento é prover o estudante de uma metodologia a que recorra em qualquer outro fenômeno semelhante, formando uma Base Orientadora de suas próximas ações. Das três professoras acompanhadas, apenas uma demonstrou, mesmo que parcialmente, a utilização dessa metodologia.

Concordamos com Galperin (1969 in Shuare, 1987, tradução nossa), quando argumenta que o objetivo da instrução formal consiste primordialmente em se ensinar ao estudante a realização de ações mentais. Esse tipo de atividade deve ser cuidadosamente delineado pelo professor. Ela tem a função de servir de base orientadora das ações, funcionando como um guia. Ela necessita incluir as circunstâncias, o delineamento da ação e o seu controle, a fim de melhor guiar as ações, permitindo eventuais correções de direção por parte do estudante.

Outro aspecto teórico importante a se considerar é que os conceitos não surgem no sujeito simplesmente como resultado de uma elaboração lógica desses ou daqueles elementos da experiência ou da atividade didática. Muitas vezes, somente mais tarde no desenvolvimento é que o sujeito toma consciência deles e lhes dá configuração lógica. Isso ocorre porque o conceito é dependente do estabelecimento das funções complexas, como a linguagem, o pensamento, a emoção, a memória mediada e a consciência, que estão em constante transformação.

A partir do acompanhamento das aulas, inferimos que, em termos escolares, revela-se outro momento característico do uso dos conceitos na adolescência, que é a necessidade do emprego do conceito em situação concreta ou da vida cotidiana. Percebemos que os conceitos ensinados estão apartados da vida cotidiana dos estudantes. Apesar dos esforços das professoras em relacionar com aspectos da realidade, há um distanciamento da realidade concreta da vida. Existe uma clara separação entre os significados sociais e os sentidos pessoais relativos aos conceitos científicos. 
Estudos realizados por Vigotski evidenciaram que "as maiores dificuldades que o adolescente tem e, que, só costumam superar ao término da idade de transição (adolescência), consiste na contínua transferência do sentido ou significado do conceito, elaborado para situações concretas, para o plano abstrato" (VIGOTSKI, 2001, p. 231). Assim, o movimento de transição do concreto para o abstrato não é mais fácil do que a transição do abstrato para o concreto. Entendemos que a mediação do professor é essencial para estabelecer esse movimento, através da apresentação de questões problemas aos estudantes que os levem a relacionar os conceitos científicos às questões da vida concreta.

A situação concreta é importante para que os estudantes tomem consciência dos conceitos científicos. Sendo assim, é necessário que, tanto quanto possível, o professor faça a correlação entre o conceito científico e a vida cotidiana, introduzindo situações variadas em que os conceitos estejam presentes, quer seja por meio de produtos ou das tecnologias decorrentes. Verificamos, pelas observações das aulas, que as professoras tiveram muita dificuldade em relacionar os conceitos com a vida cotidiana dos alunos, o que possibilitaria a relação do abstrato com o concreto.

Vimos, também, que o conceito era apresentado fora do contexto de sua produção, seja pela inabilidade das professoras em explicar o processo histórico de sua gênese, seja pela falta de um ambiente adequado para a sua demonstração (laboratório). O livro didático, que era o principal meio de acesso ao conhecimento pelos estudantes, também contribuiu para que os conceitos fossem conhecidos em sua forma final, como algo pronto e acabado, num plano inteiramente abstrato, muitas vezes distantes das possibilidades da imaginação do estudante.

Nesta pesquisa, depreendemos o quão essencial é o papel desempenhado pelo professor na construção dos conceitos científicos. Para que esse papel possa efetivamente se concretizar, urge colocar em movimento um conjunto de atividades de ensino, que favoreçam a relação entre os estudantes e o professor e uma boa interação do sujeito com o conhecimento. Essas atividades precisam ser planejadas minuciosamente, para que o processo se aproxime de um resultado adequado. A utilização de um plano específico de atividades de modo a predizer a formação das ações mentais, através de seus estágios específicos, conforme preconiza Galperin, é um aspecto a ser observado. 
Segundo a Teoria Histórico-Cultural, a linguagem desempenha uma função basilar no processo de construção dos conceitos científicos. Parece-nos adequado que o professor se empenhe em produzir atividades que levem o estudante a lidar tanto com a linguagem verbal quanto com a escrita, de modo a favorecer a construção dos conceitos. O desenvolvimento da linguagem não depende de uma área específica de conhecimento. Assim, as atividades verbais orientadas e escritas devem fazer parte de todas as atividades educativas e necessitam ser incentivadas pelos professores.

Quando o conceito era apresentado 'já pronto' aos estudantes, através de uma proposição, sem a devida problematização, tanto o estudante quanto o professor tinham a falsa impressão de que o conceito foi aprendido. Fato é que os estudantes necessitam estudar para a avaliação, mesmo quando a 'prova' ocorre após a apresentação verbal ou escrita do conceito. E a situação se complica quando eles são expostos a situações problema, em que o conceito deve ser aplicado. Conforme já discutimos, um conceito científico é uma forma de organização da realidade, que proporciona ao sujeito não somente descrever os fenômenos, mas explicá-los.

A exploração dos conhecimentos prévios dos estudantes e a revelação de que eles estão presentes na vida cotidiana foram estratégias significativas para a formação dos conceitos, embora não tenham sido muito exploradas pelas professoras. Elas geralmente não consideravam o que os estudantes já sabiam sobre o assunto. $\mathrm{O}$ conceito era inserido como se os estudantes nada soubessem.

Evidenciamos que uma parte expressiva da atividade docente está pautada por ações e operações em que os objetivos não são acordados e discutidos com os estudantes, inviabilizando a compreensão dos motivos da atividade. Assim, os significados sociais e os sentidos pessoais do processo de ensino-aprendizagem não estão devidamente explicitados.

Outra questão que consideramos fundamental no processo de ensino de conceitos foram os aspectos motivacionais. Havia pouco encorajamento e estímulos às atividades dos estudantes por parte das professoras. González Serra (2008, p. 52) explica que “o estudo da cognição está incompleto se não se levar em conta, toda a importância que a afetividade tem nela e igualmente, o estudo da afetividade e da motivação não está completo se não se estuda a importância que tem os fatores cognoscitivos nelas". 
Percebemos o quanto é relevante o papel da motivação extrínseca, que muitas vezes se mostrou ausente nas aulas. Entendemos a motivação como um reflexo da realidade, portanto, derivada das situações didáticas estabelecidas $a$ priori pelo professor, sem desconsiderar a função primordial da personalidade dos estudantes nesse processo.

Finalmente, desta tese resultou a assertiva de que a teoria desenvolvida por A. N. Leontiev possui um conjunto de premissas e categorias apropriadas para estudos do processo educativo e do ensino desenvolvimental, conforme preconiza Davidov. A atividade de estudo deve deixar de ser de satisfação de uma necessidade externa, alheia ao estudante, para se tornar um meio de satisfazer as necessidades internas e reais.

Nesse caso, o sentido e o significado de escola, como lócus privilegiado para aprender os conhecimentos produzidos e acumulados pela sociedade como forma de transformá-la, não se materializam ou se evidenciam. O que constatamos é uma profunda alienação, vivida pelo estudante, dos sentidos e significados da atividade educativa. O processo de instrução tornou-se estranho ao seu ser. Em outras palavras, ele passa a não identificar o objeto de sua ação, que é o motivo real de sua atividade.

Chegamos ao término desta tese com a constatação de que o processo de formação de conceitos, por nós estudados empiricamente, se insere numa totalidade que, certamente, é mais rica em explicações do que a própria parte estudada. Temos a noção de que, mesmo procurando, em nosso estudo, a perspectiva de totalidade, não conseguimos esgotá-la, ainda que provisoriamente. Terminamos pela indicação da necessidade de novos estudos, com a ampliação e a diversificação da amostra utilizada, para consubstanciar as nossas inferências. E conforme iniciamos esta tese, finalizamos com o insight de Fausto, personagem de Goethe: "Agora é que atinei: no princípio era a ação”. 


\section{Referências bibliográficas}

ANJOS, R.; DUARTE, N; E. A teoria da individualidade para si como referência à análise da educação escolar de adolescentes. Nuances: estudos sobre Educação, Presidente Prudente-SP, v. 28, n. 3, p. 115-132, Set/Dez, 2017.2 Disponível em: <http://revista.fct.unesp.br/index.php/Nuances/article/view/4183/ PDF> Acesso em: 15 jun 2018.

ANDRADE, D. M. O tamanho da família como fator sociodemográfico a interferir na escolarização dos filhos. Comunicação ANPED. GT-14 [Recurso eletrônico] Disponível em: <http://www.anped.org.br/sites/default/files/gt14-4174-int.pdf> Acesso em: 15 julh 2018.

ARROYO, M. G. Pobreza, desigualdades e educação. (Módulo introdutório). Brasília: DF, 2014. Disponível em: <http://catalogo.egpbf.mec.gov.br/modulos/pdf/intro.pdf> Acesso em: 15 junho 2018.

ASBAHR, F. S. F. "Por que aprender isso professora" Sentido pessoal e atividade de estudo na Psicologia Histórico-Cultural. $220 f$. Tese (Doutorado em psicologia) Universidade de São Paulo. Orientadora: Marilene Proença Rebello de Souza. São Paulo, 2011.

AUSUBEL, D. P.; NOVAK, J. D.; H. HANESIAN, Psicologia Educacional. Rio de Janeiro: Interamericana, 1980.

BARROSO, S. M. S., FACCI, M. G. D., TULESKI, S. C. Psicologia Histórico-Cultural, marxismo e educação. Teoría y crítica de la psicología 3, 281-301 (2013). ISSN: 2116-3480. Disponível em: <http://www.teocripsi.com/ojs/index.php/TCP/article/view/112/96>. Acesso em: 10 mar 2018.

BATISTA, U. A. D.; LIMA, M. F. Considerações sobre a trajetória histórica da formação profissional no Brasil de 1940 a 1990. Emancipação, Ponta Grossa, 11(1): 35-47, 2011. Disponível em: $<$ http://www.revistas2.uepg.br/index.php/emancipacao> Acesso em: 15 jul 2018.

BRANDÃO, C. F. O ensino médio no contexto do plano nacional de educação: o que ainda precisa ser feito. Cad. Cedes, Campinas, vol. 
31, n. 84, p. 195-208, maio-ago. 2011. Disponível em: <http://www.scielo.br/pdf/ccedes/v31n84/a03v31n84.pdf> Acesso em: 15 jun 2018.

BRASIL. [Constituição (1988)]. Constituição da República Federativa do Brasil de 1988. Brasília, DF: Presidência da República. Disponível em: < http://www2.camara.leg.br/legin/fed/consti/1988/constituicao-1988-5outubro-1988-322142-publicacaooriginal-1-pl.html> Acesso em: 15 de jun 2015.

ensino
Decreto-lei no $\mathbf{4 . 2 4 4}$, de 9 de abril de 1942. Lei orgânica do
secundário. <http://www2.camara.leg.br/legin/fed/declei/1940-1949/decreto-lei-4244-9abril-1942-414155-publicacaooriginal-1-pe.html> Acesso em: 15 maio 2017.

. Lei no 5.692, de 11 de agosto de 1971. Fixa as Diretrizes e Bases para 0 ensino de $1^{\circ}$ e $2^{\circ}$ graus, e dá outras providências. Disponível em: < http://www2.camara.leg.br/legin/fed/lei/1970-1979/lei5692-11-agosto-1971-357752-publicacaooriginal-1-pl.html> Acesso em: 15 jun 2017.

. Lei $\mathrm{n}$ - 7.044, de 18 de Outubro de $\mathbf{1 9 8 2}$. Altera dispositivos da Lei $n^{\circ}$ 5.692, de 11 de agosto de 1971, referentes a profissionalização do ensino de 2o grau. Disponível em: <http://www2.camara.leg.br/legin/fed/lei/1980-1987/lei-7044-18-outubro1982-357120-publicacaooriginal-1-pl.html> Acesso em: 15 jun 2017.

Lei n. 9.394, de 20 de dezembro de 1996. Estabelece as diretrizes e bases da educação nacional. Disponível em: <http://www2.camara.leg.br/legin/fed/lei/1996/lei-9394-20-dezembro-1996362578-publicacaooriginal-1-pl.html> Acesso em: 15 julh 2017.

. Decreto no 2.208, de 17 de Abril de 1997. Regulamenta o $\S 2^{\circ}$ do art. 36 e os arts. 39 a 42 da Lei no 9.394, de 20 de dezembro de 1996, que estabelece as diretrizes e bases da educação nacional. Disponível em: < http://www2.camara.leg.br/legin/fed/decret/1997/decreto-2208-17abril-1997-445067-publicacaooriginal-1-pe.html> Acesso em: 15 julh 2017.

Conselho Nacional de Educação. Resolução CNE/CEB no 3, de 26 de junho de 1998. Institui as Diretrizes Curriculares Nacionais para 0 Ensino Médio. Brasília: Ministério da Educação, 1998. Disponível em: $<$ http://portal.mec.gov.br/cne/arquivos/pdf/rceb03_98.pdf>. Acesso em: 20 fev. 2017.

- Instituto Brasileiro de Geografia e estatística - IBGE. Pesquisa Nacional por Amostra de Domicílio, 2016 - educação. IBGE, 2017. Disponível em: https://biblioteca.ibge.gov.br/visualizacao/livros/liv98887.pdf> Acesso em: 15 Ago. 2017. 
. Instituto Nacional de Pesquisas Educacionais Anisio Teixeira. Estatísticas sobre educação básica. Brasília: Instituto Nacional de Pesquisas Educacionais, 2015. Disponível em: < http://download.inep.gov.br/informacoes_estatisticas/sinopses_estatisticas /sinopses_educacao_basica/sinopse_estatistica_educacao_basica_2015. zip> Acesso em: 15 jun 2017.

- Instituto Nacional de Pesquisas Educacionais Anisio Teixeira. Estatísticas sobre educação básica. Brasília: Instituto Nacional de Pesquisas Educacionais, 2016. Disponível em: < http://download.inep.gov.br/educacao_basica/censo_escolar/notas_estatis ticas/2017/notas_estatisticas_censo_escolar_da_educacao_basica_2016. pdf> Acesso em: 15 julh $201 \overline{7}$.

CIAVATTA, M.; RAMOS, M. Ensino Médio e Educação Profissional no Brasil: Dualidade e fragmentação. Revista Retratos da Escola, Brasília, v. 5 , n. 8 , p. 27-41, jan./jun. 2011. Disponível em: < http://retratosdaescola.emnuvens.com.br/rde/article/viewFile/45/42> Acesso em: 15 julho 2018.

\section{CUNHA, L. A. A Educação Brasileira na Primeira Onda Laica: do Império à República. Disponível em: < http://www.luizantoniocunha.pro.br/uploads/livros/AEducacaoBrasileirana PrimeiraOndaLaica.pdf>. Acesso em: 15 de jun 2018.}

CUNHA, L. A. O ensino profissional: o grande fracasso da ditadura. Cadernos de pesquisa. v.44 n.154 p.912-933 out./dez. 2014. Disponível em: < http://www.scielo.br/pdf/cp/v44n154/1980-5314-cp-44-15400912.pdf> Acesso em: 15 junh 2018.

DAVIDOV, V.; SHUARE, M., (Orgs.) La psicologia evolutiva y pedagógica enla URSS (Antología). Moscou, Progresso, 1987. Disponível em: <https://docplayer.es/40307070-La-psicologia-evolutiva-ypedagogica-en-la-urss-antologia.html> Acesso em: 15 jun 2015.

DUARTE, N. A. Vigotski e o "aprender a aprender": crítica às apropriações neoliberais e pós-modernas da teoria vigotskiana. Campinas, São Paulo: Autores associados, 2001.

ELKONIN, D. B. Sobre el problema de la periodización del desarrollo psíquico enlainfancia. In: DAVIDOV, V.; SHUARE, M., orgs. La psicologia evolutiva y pedagógica enla URSS (Antología). Moscou, Progresso, 1987. p.104-24.

,O desenvolvimento de conceitos na cognição e na linguagem. Fractal: Revista de Psicologia, v. 27, n. 1, p. 74-77, jan.-abr. 2015. doi: <http://dx.doi.org/10.1590/1984-0292/1361> Acessado em: 01 Abr. 2016. 
ENGELS, F. Sobre o papel do trabalho na transformação do macaco em homem. 33p. [Versão ebook] 2005. Disponível em: $<$ http://www.ebooksbrasil.org/adobeebook/macaco.pdf> Acesso em: 10 jun 2017.

FERREIRA, E. B. A contrarreforma do ensino médio no contexto da nova ordem e progresso. Educ. Soc., Campinas, v. 38, no. 139, p.293308, abr.-jun., 2017.2 Disponível em: <http://www.scielo.br/pdf/es/v38n139/1678-4626-es-38-139-00293.pdf> Acesso em: 15 jul 2018.

FERRETE, C. J.; SILVA, M. R. Reforma o ensino médio no contexto da medida provisória no 746/2016: estado, currículo e disputa por hegemonia. Educ. Soc., Campinas, v. 38, №. 139, p.385-404, abr.-jun., 2017. Disponível em: <http://www.scielo.br/pdf/es/v38n139/1678-4626-es38-139-00385.pdf> Acesso em: 15 jun 2018.

FRIGOTTO, G.; CIAVATTA, M. Educação básica no Brasil na década de 1990: subordinação ativa e consentida à lógica do mercado. Educ. Soc., Campinas, vol. 24, n. 82, p. 93-130, abril 2003. Disponível em: < http://www.scielo.br/pdf/es/v24n82/a05v24n82.pdf> Acesso em: 15 jun 2018.

FRIGOTTO, G. Teoria e práxis e o antagonismo entre a formação politécnica e as relações sociais capitalistas. Trab. Educ. Saúde, Rio de Janeiro, v. 7, suplemento, p. 67-82, 2009. Disponível em: <http://www.scielo.br/pdf/tes/v7s1/04.pdf> Acesso em: 15 maio 2018.

GALPERIN, P. Ya., ZAPORÓZHETS A., \& ELKONIN, D. Los problemas de la formación de conocimientos y capacidades en los escolares y los nuevos métodos de enseñanza en la escuela. In M. Shuare \& V. Davidov (Orgs.). La psicologia evolutiva y pedagógica en la URSS. Moscú: Editorial Progreso, 1987.

GERMER, C.M. (2003). A relação abstrato/concreto no método da economia política. In: Corazza, G. (Org.). Métodos da ciência econômica. Porto Alegre: Editora da UFRGS. Disponível em: $<$ https://docplayer.com.br/11520259-A-relacao-abstrato-concreto-nometodo-da-economia-politica-claus-magno-germer-introducao.html> Acesso em: 15 jun 2018.

GOETHE, J. W. Fausto. Quadro IV. Cena I. [105-109]. Tradução de António Feliciano de Castilho Disponível em: http://www2.dlc.ua.pt/castilho/Fausto/Fausto_quadro04.htm Acesso em: 15 jun. 2018.

GONZÁLEZ SERRA, D. J. Psicología de la motivacíon. Havana, Cuba: Editorial ciências médicas, 2008. 
HOBSBAW, J. E. A era dos impérios: 1875-1914. Cap. 12. Rio de Janeiro: Paz e Terra S.A., 2002.

IBGE - INSTITUTO BRASILEIRO DE GEOGRAFIA E ESTATÍSTICA. Pesquisa Nacional por Amostra de Domicílios Contínua - PNAD 20162017 - microdados da amostra, 2017.

KONDER, L. O que é dialética. São Paulo: Editora e livraria brasiliense, 2008.

KUENZER, A. Z. Educação e trabalho no Brasil: o estado da questão. Brasília: INEP, 1991.

KUENZER, A. Z. (Org.). Ensino Médio: construindo uma proposta para os que vivem do trabalho. São Paulo: Cortez, 2007.

KUENZER, A. Z. O Ensino Médio no Plano Nacional de Educação 2011-2020: Superando a Década Perdida. Educação e Sociedade, Campinas, v. 31, n. 112, p. 851-873, jul.-set. 2010. Disponível em: < http://www.scielo.br/pdf/es/v31n112/11.pdf> Acesso em: 15 julh 2018.

KUENZER, A. Z.; G. BRABOWSK A produção do conhecimento no campo da educação profissional no regime de acumulação flexível. HOLOS, Ano 32, Vol. Disponível em: < http://www2.ifrn.edu.br/ojs/index.php/HOLOS/article/download/4983/1566> Acesso em: 15 jun 2018.

KUENZER, A. Z. Trabalho e escola: a flexibilização do ensino médio no contexto do regime de acumulação flexível. Educ. Soc., Campinas, v. 38, no. 139, p.331-354, abr.-jun., 2017. Disponível em: < http://www.scielo.br/pdf/es/v38n139/1678-4626-es-38-139-00331.pdf> Acesso em: 15 jun 2018.

LAKATOS, E. M.; MARCONI M. A. Fundamentos de metodologia científica. 5aㅡ. Ed. São Paulo: Editora Atlas, 2003.

LENT, R. (Org.) Neurociência da mente e do comportamento. Cap. 5 Rio de Janeiro: Guanabara Koogan S.A, 2008.

LEONTIEV, A. N. Sobre o desenvolvimento criativo de Vigotski. On Vygotsky's Creative Development. Publicado em 1989 como prefácio ao volume 3 das Obras Escolhidas de Vigotski em inglês. Traduzido por Marcelo José de Souza e Silva. Disponível no Marxists Internet Archive. <https://www.marxists.org/portugues/leontiev/1979/01/vigotski.htm> Acesso em: 23 jan. 2018.

LEONTIEV, A. N. Actividad, conciencia e personalidad. Buenos Aires: ediciones ciência del hombre, 1978a. 
Actividad, conciencia e personalidade. Havana: Editorial pueblo e educación, 1983.

, Actividad, conciencia e personalidade. México: editorial Cartago Mexico, 1984. Editora, 2004.

O desenvolvimento do psiquismo. São Paulo: Centauro

LEONTIEV, A. N. EI hombre y la cultura. El texto corresponde al capítulo 3 del libro El hombre nuevo, editado por Martínez Roca, S.A. Barcelona, 1969. OMEGALFA. Biblioteca virtual, 2013. Disponível em: $<$ https://omegalfa.es/downloadfile.php?file=libros/el-hombre-y-la-

cultura.pdf> Acesso em: 15 julh 2018.

LIBÂNEO, J. C. Didática. São Paulo: Editora Cortez, 2ª ed., 1990.

LIBÂNEO, J. C. A teoria do ensino para o desenvolvimento humano e o planejamento de ensino. Educativa, Goiânia, v. 19, n. 2, p. 353-387, maio/ago. 2016.2 Disponível em: <https://www.researchgate.net/publication/313941644_A_teoria_do_ensin o_para_o_desenvolvimento_humano_e_o_planejamento_de_ensino> Acesso em: 10 jun 2017.

LONGAREZI, A. M.; VALdÉZ PUENTES, R. (Org.) Ensino desenvolvimental. Antologia. Livro I. (p. 39-57) Minas Gerais, Uberlândia: EDUFU, 2017.

LONGAREZI, A. M.; VALDÉZ PUENTES, R. (Org.) Ensino desenvolvimental: vida, pensamento e obra dos principais representantes russos. Antologia. Livro II. Minas Gerais, Uberlândia: EDUFU, 2017.

LUCKESI, C. C. A avaliação da aprendizagem escolar: estudos e proposições. São Paulo: Cortez Editora, 1994.

LURIA, A. R. Fundamentos de neuropsicologia. São Paulo: Ed. da Universidade de São Paulo, 1981.

- Introducion evolucionista a la psicología. Matínez Roca: Barcelona, 1985. Pág. 99-117.

, Pensamento e linguagem: as últimas conferências de Luria. Porto Alegre: ARTMED Editora Ltda., 2001.

MARCHESI, A; COL, C.; PALACIOS, J. (Org.) Desarollo psicológico y educación, III. Necessidades educativas especiales y aprendizaje escolar. España: Alianza Psicología, 1990. Vol. 2: II. Psicología de la educación. 93-119. 
MARCUSCHI, L. A. Análise da conversação. São Paulo: Ática, 1986. (Série Princípios).

MARTINS, L. M. O desenvolvimento do psiquismo e a educação escolar: contribuições à luz da psicologia histórico-cultural e da pedagogia histórico-crítica. São Paulo: Autores associados, 2013.

MARTINS, L. M.; ABRANTES, A. A.; FACCI, M. G. D. (Org.) Periodização histórico-cultural do desenvolvimento psíquico: do nascimento à velhice. Campinas, São Paulo: Autores associados, 2017.

MARTINS, L. M. Análise sócio-histórica do processo de personalização de professores. 194f. Tese de Doutorado. Programa de Pós-graduação em Educação, Faculdade de Filosofia e Ciências, UNESP. Marília, 2001.

MARX, K. Manuscritos econômicos filosóficos. Tradução e notas de Jesus Ranieri. São Paulo: Boitempo Editorial Ltda., 2004.

O capital: crítica da economia política. [Recurso eletrônico] Livro I. O Processo de produção do capital. São Paulo: Boitempo, 2013. Disponível em: http://www.gepec.ufscar.br/publicacoes/livros-ecolecoes/marx-e-engels/o-capital-livro-1.pdf/at_download/file Acesso em: 15 jun 2017.

. Contribuição à crítica da economia política. Prefácio. São Paulo: Editora Expressão Popular, 2008.

$\begin{array}{cccr}\text { Boitempo } & \begin{array}{c}\text { Grundisse. Introdução. [Recurso eletrônico] São } \\ \text { Editorial, }\end{array} 2011 . & \text { Paulo: }\end{array}$ https://nupese.fe.ufg.br/up/208/o/Karl_Marx__Grundrisse_(boitempo)_completo.pdf Acesso em: 15 jun 2017.

Teses sobre Feuerbach. [Recurso eletrônico] Disponível em <https://filosoficabiblioteca.files.wordpress.com/2013/10/marx-tesessobre-feuerbach-edic3a7c3a3o-completa.pdf> Acesso em: 15 de mai 2018.

Elementos fundamentales para la critica de la economia politica (Grundrisse). 14.ed. México, SigloVeinteuno, 1986.

MEDEIROS, D. H. Aprendizagem conceitual e desenvolvimento do pensamento teórico: (im) possibilidade da organização do ensino. 154 f. Universidade Estadual de Maringá - UEM. Tese (doutorado em educação). Orientadora: Marta Sueli de Faria Sforni Maringá, 2014. Disponível em: <http://gepae-uem.blogspot.com.br/p/blog-page.html> Acesso em 26 mar. 2015. 
MÉSZÁROS, I. Para além do capital: rumo a uma teoria da transição. Trad. Paulo César Castanheira e Sérgio Lessa. São Paulo, Editora da UNICAMP/BOITEMPO Editorial, maio de 2002.

A educação para além do capital. Trad. Isa Tavares. São Paulo: Boitempo, 2014.

MINAYO, M. C. S. (Org.) Pesquisa social: teoria método e criatividade. Petrópolis: Editora Vozes, 2002.

MIZUKAMI, M. G. N. Ensino: as abordagens do processo. São Paulo: Editora Pedagógica e Universitária, 1986.

MORTIMER, E. F., SCOTT P. H. A atividade discursiva nas salas de aula de ciências: uma ferramenta sociocultural para analisar e planejar o ensino. Investigações em Ensino de Ciências. Porto Alegre - RS, v.7, n.3, 2002.

MORTIMER, E. F., SMOLKA, A. L. B. Linguagem, cultura e cognição reflexões para o ensino e a sala de aula. Belo Horizonte: Autêntica, 2001.

MORTIMER, E. F., MACHADO, A. M. A Linguagem Numa Sala de Aula de Ciências. Presença Pedagógica. Belo Horizonte: Dimensão, v.2, n.11, p.49-57, 1996.

MORTIMER, E.F. Linguagem e formação de conceitos no ensino de ciências. Belo Horizonte: Editora UFMG, 2000.

NOGUEIRA, D. M. O tamanho da família como fator sociodemográfico a interferir na escolarização dos filhos. GT-14: sociologia da educação. 2008. Disponível em: <http://www.anped.org.br/sites/default/files/gt144174-int.pdf> Acesso em: 15 julh. 2018.

OLIVEIRA, M. K. Vygotsky aprendizado e desenvolvimento: um processo sóciohistórico. São Paulo: Scipione, 1997.

PANIAGO, M. L. "Livro" didático: a simplificação e a vulgarização do conhecimento. São Paulo: Instituto Lukács, 2013.

PEREIRA, J. G. O patrimônio ambiental urbana de Corumbá-MS: identidade e planejamento. 238p. Universidade de São Paulo. Tese (Doutorado em ciências Humanas: Geografia). Orientador: Prof. Dr. Eduardo A.Yázigi.

PICOLLO, G. M. Historicizando a teoria da atividade: do embate ao debate. Psicologia \& Sociedade; 24 (2), 283-292, 2012. Disponível em: $<$ http://www.scielo.br/pdf/psoc/v24n2/04.pdf> Acesso em: 15 de maio 2018. 
PRESTES, Z. R., TUNES, E. Vigotski e Leontiev: ressonâncias de um passado. Cadernos de Pesquisa, v. 39, n. 136, jan./abr. 2009. Disponível em: <http://www.scielo.br/pdf/cp/v39n136/a1439136.pdf>. Acesso em: 15 mar 2018.

PRESTES, Z. R. TUNES, E. (Org.) 7 Aulas de L. S. Vigotski sobre os fundamentos da pedologia. Rio de Janeiro: E-papers Serviços Editoriais Ltda., 2018.

PRESTES, Z. R. Quando não é quase a mesma coisa: Análise de traduções de Lev Semionovitch Vigotski no Brasil Repercussões no campo educacional. 295f. Tese (Doutorado em Educação) Universidade de Brasília, Brasília, Distrito Federal, 2010.

Quando não é quase a mesma coisa. Traduções de Lev Semionovitch Vigotski no Brasil. São Paulo: Autores associados, 2012.

REED, J. Os dez dias que abalaram o mundo. São Paulo: Editora Schwarcz S. A., 2016.

RUBINSTEIN, S. L., El desarollo de la psicología: princípios y métodos. Buenos Ayres: Grijalbo S.A, Argentina, 1974.

S. L. Princípios de psicologia general. México DF: Editorial Grijalbo, S.A, México, 1978.

SAVIANI, D. A escola pública brasileira no longo século XX (18902001). Trabalho realizado com apoio do CNPq. III Congresso Brasileiro de História da Educação. Sessão de Comunicação Coordenada: "O século XX brasileiro: da universalização das primeiras letras ao Plano Nacional de Educação (1890-2001)". Curitiba, 7 a 10 de novembro de 2004. Disponível em: <http://www.redalyc.org/pdf/715/71509907.pdf> Acesso em: 15 de maio de 2018.

SAVIANI, D. As concepções pedagógicas na história da educação brasileira. Texto elaborado no âmbito do projeto de pesquisa "O espaço acadêmico da pedagogia no Brasil", financiado pelo CNPq, para o "Projeto 20 anos do Histedbr". Campinas, 25 de agosto de 2005. Disponível em: $<$ http://www.histedbr.fe.unicamp.br/navegando/artigos_pdf/Dermeval_Savi ani_artigo.pdf> Acesso em: 15 junho 2018.

SAVIANI, D. Trabalho e educação: fundamentos ontológicos e históricos. Revista Brasileira de Educação v. 12 n. 34 jan./abr. 2007. Disponível em: <http://www.scielo.br/pdf/\%0D/rbedu/v12n34/a12v1234.pdf> Acesso em: 15 de abril de 2018.

SAVIANI, D. História da história da educação no Brasil: um balanço prévio e necessário. EccoS - Revista Científica, São Paulo, v. 10, n. 
especial, p. 147-167, 2008. Disponível em: $<$ http://www.redalyc.org/pdf/715/71509907.pdf> Acesso em: 15 de maio de 2018.

SAVIANI, D. O legado educacional do regime militar. Cad. Cedes, Campinas, vol. 28, n. 76, p. 291-312, set./dez. 2008. Disponível em: <http://www.scielo.br/pdf/ccedes/v28n76/a02v2876.pdf>. Acesso em: 15 de mai de 2018.

SAVIANI, D. Transformações do capitalismo, do mundo do trabalho e da educação. IN: LOMBARDI, José Claudinei; SAVIANI, Demerval; SANFELICI, Jose Luis (org). Capitalismo, trabalho e educação. Campinas/SP: Autores Associados, HISTEDBR, 2005.

SAVIANI, D. Escola e democracia. Edição Comemorativa. Campinas: Autores Associados, 2008.

. Pedagogia histórico-Crítica. 11aㅡ Ed. Campinas, SP: Editora Autores Associados, 2013.

SFORNI, M. S. F. Aprendizagem conceitual e organização do ensino: contribuições da teoria da atividade. 166f. Tese de doutorado. Faculdade de Educação, Universidade de São Paulo, São Paulo, 2003.

SFORNI, M. S. F. Aprendizagem conceitual e organização do ensino: contribuições da teoria da atividade. São Paulo: JM editora Ltda, 2004.

SFORNI, M. S. F.. A produção científica brasileira sobre a organização do ensino fundamentada na Teoria Histórico-Cultural. In: XI Jornada do HISTEDBR, 2013, Cascavel. Anais. Cascavel, 2013, p. 01 16 Disponível em: <http://www.histedbr.fe.unicamp.br/acer_histedbr/jornada/jornada11/artigo s/9/artigo_simposio_9_832_martasforni@uol.com.br.pdf> Acesso em: 15 jun 2018.

SFORNI, M. S. F., VIEIRA, V. A. M. A. Aprendizagem conceitual. Educar em Revista, Curitiba, Brasil, n. especial 2, p. 45-58, 2010. Editora UFPR. Disponível em: <http://www.scielo.br/pdf/er/nspe2/03.pdf> Acesso em: 15 de maio de 2018.

SHUARE, M. La psicologia evolutiva e pedagogica el na URSS. Biblioteca de psicologia soviética. Antología. Bogotá, Colombia: Editorial Progresso, 1987.

La psicologia soviética tal como yo la veo. Moscú: Editorial PROGRESO, URSS, 1990.

A psicologia soviética: meu olhar. São Paulo: Terracota, 2016. SIMON, B. Psychology in the Soviet Union. Part IV. P. 213. London: Routledge \& Kegan Paul Ltd. 1957. 
SOUZA, J. A. M. Recuperando a dialética no materialismo histórico de vigotski. Psicol. Soc. vol.28 no 1, Belo Horizonte Jan./Apr. 2016

TALÍZINA, N. F. Manual de psicología pedagógica. México: Editorial Universitaria Potosina, 2000.

TOASSA, G. Conceito de consciência em Vigotski. Psicologia USP, 2006, 17(2), 59-83. Disponível em: <http://www.scielo.br/pdf/pusp/v17n2/v17n2a04.pdf> Acesso em: 15 jul 2017.

TOASSA, G. Emoções e vivências em Vigotski: investigação para uma perspectiva histórico-cultural. 2009 348p. Tese (Doutorado Programa de Pós-Graduação em Psicologia. Área de Concentração: Psicologia Escolar e do Desenvolvimento Humano) - Instituto de Psicologia da Universidade de São Paulo. Orientadora: Marilene Proença Rebello de Souza.

TOASSA, G. Nem tudo que reluz é Marx: críticas stalinistas a Vigotski no âmbito da ciência soviética. 2016, volume 27, número 3 (553-563). Disponível em: <http://www.scielo.br/pdf/pusp/v27n3/1678-5177-pusp-2703-00553.pdf> Acesso em: 15 de jun 2018.

TOASSA, G. "Atrás da consciência, está a vida": o afastamento teórico leontiev-vigotski na dinâmica dos círculos vigotskianos. Educ. Soc., Campinas, v. 37, o․ 135, p.445-462, abr.-jun., 2016. Disponível em: <http://www.scielo.br/pdf/es/v37n135/1678-4626-es-37135-00445.pdf> Acesso em: 15 mar 2018.

TEIXEIRA, P. M. M.. Pesquisa em Ensino de Biologia no Brasil (19722004): um estudo baseado em dissertações e teses. (Tese e Doutorado em Educação). Universidade Estadual de Campinas, Campinas/SP, 2008.

TEIXEIRA, P. M. M. 35 anos da produção acadêmica em Ensino de Biologia no Brasil: catálogo analítico de dissertações e teses (19722006). V. Conquista: Ed. UESB, 2012

TEIXEIRA, P. M. M., \& MEGIDE NETO, J. Investigando a pesquisa educacional. Um estudo enfocando dissertações e teses sobre 0 ensino de Biologia no Brasil. Investigações em Ensino de Ciências, 11(2), 261-282, 2006.

TEIXEIRA, P. M. M., \& TEIXEIRA, J. Pós-Graduação e pesquisa em ensino de Biologia no Brasil: um estudo baseado em dissertações e teses. Ciência \& Educação, 17(3), 559-578, 2011.

TEIXEIRA, P. M. M., \& TEIXEIRA, J. O estado da arte da pesquisa em ensino de Biologia no Brasil: um panorama baseado na análise de 
dissertações e teses. Revista Electrónica de Enseñanza de las Ciencias, 11(2), 273-297, 2012.

TEIXEIRA, P. M. M., \& TEIXEIRA, J. A produção acadêmica de ensino de biologia no Brasil - 40 anos (1972-2011): base institucional e tendências temáticas e metodológicas. RBPEC 17(2), 521-549. Agosto 2017.

TOASSA, G., DELARI JÚNIOR, A. Sobre métodos para pesquisa de conceitos. Fractal, Rev. Psicol., v. 25 - n. 3, p. 695-722, Set./Dez. 2013. Disponível em: <http://periodicos.uff.br/fractal/article/view/4968/4810> Acesso em: 15 junho 2018.

Sakharov e os métodos para pesquisa da formação de conceitos. Psicol., v. 25 - n. 3, p. 645-658, Set./Dez. 2013 Disponível em: <http://www.scielo.br/pdf/fractal/v25n3/a14v25n3.pdf> Fractal, Rev.. Acesso em: 15 junho 2018.

A Revolução Russa e o resgate de uma perspectiva revolucionária. Lutas Sociais, São Paulo, vol.21 n.38, p.123-135, jan./jun. 2017. Disponível em: < <https://revistas.pucsp.br/index.php/ls/article/viewFile/33248/pdf> Acesso em: 15 mar 2017.

TULESKI, S. C. A unidade dialética entre corpo e mente na obra de A. R. Luria: implicações para a educação escolar e para a compreensão dos problemas de escolarização. 2007. 363 p. Tese (doutorado em educação) - Universidade Estadual Paulista, SP, 2007.

VAN DER VEER, R., VALSINER, J. Vygotsky: uma síntese. São Paulo: Loyola, 1996.

VIGOTSKI, L.S. Pensamiento e habla.Buenos Aires: EditoraColihue, 2012.

VYGOTSKY, L. S., A construção do pensamento e da linguagem. São Paulo: Martins Fontes, 2001.

Martins Fontes 2003.

O desenvolvimento psicológico na infância. São Paulo: Psicologia pedagógica. São Paulo: Martins Fontes, 2004.

2004.

, Teoria e método em psicologia. São Paulo: Martins fontes,

, Pensamento e linguagem. São Paulo: Martins Fontes, 2008.

, A formação social da mente. São Paulo: Martins Fontes, 2010. 
Obras escogidas. Tomo l. Disponível em: <https://edisciplinas.usp.br/pluginfile.php/289941/mod_folder/content/0/To mo\%20\%201. pdf?forcedownload=1> Acesso em: 15 de maio 2016.

Obras escogidas. Tomo II. Disponível em: <https://edisciplinas.usp.br/pluginfile.php/289941/mod_folder/content/0/To mo\%202\%20.pdf?forcedownload=1 > Acesso em: 15 de maio 2016

Obras escogidas. Tomo III. Disponível em: <https://edisciplinas.usp.br/pluginfile.php/289941/mod_folder/content/.../To mo\%203.pdf?forcedownload=1> Acesso em: 15 de maio 2016

Obras escogidas. Tomo IV. Disponível em: <https://edisciplinas.usp.br/pluginfile.php/289941/mod_folder/content/0/To mo\%204\%20.pdf?forcedownload=1> Acesso em: 15 de maio 2016

WERTSCH, J. V.; DEL RIO, P.; ALVAREZ, A. Estudos socioculturais da mente. Porto Alegre: Artmed, 1998. 


\section{8 \\ Apêndices}

\subsection{Apêndice $\mathrm{A}$ - Questionário referente à infraestrutura da instituição} de ensino.

1. Nome da escola:

2. Endereço:

3. Bairro:

4. Quantidade de estudantes matriculados no EM:

5. A escola possui biblioteca?

6. Escola possui quadra de esportes?

7. A escola possui cantina?

8. A escola possui refeitório para os estudantes?

9. A escola oferece merenda escolar?

10. As salas de aula são climatizadas?

11. As salas de aulas possuem ventiladores?

12. A escola possui espaço livre para atividades recreativas?

13. A escola possui laboratório de ciências?

14. A escola possui laboratório de informática?

15. Os estudantes possuem acesso livre à internet?

16. Os estudantes utilizam uniformes?

17. Os estudantes utilizam livros didáticos e/ou apostilas?

18. A escola possui máquina de Xerox?

19. A escola possui retroprojetor? Projetor? Quantos?

20. A escola possui sala de professores?

21. A sala de professores é climatizada? 


\subsection{Apêndice B - Questionário relativo ao perfil das professoras.}

\section{A- Identificação do entrevistado}

1. Nome:

2. Idade:

\section{B- Formação profissional e acadêmica}

1. EM: Ano do término:

2. Curso superior (1): Ano do término: Instituição:

3. Curso superior (2): Ano do término: Instituição:

4. Pós-grad. (1): Área: Ano do término: Instituição:

5. Pós-grad. (1): Área: Ano do término: Instituição:

\section{C- Atividade profissional}

1. Tipo de vínculo empregatício?

( ) Concurso ( ) Contrato CLT ( ) Outro

2. Tempo de serviço no magistério?

( ) anos ( ) meses

3. Tempo de serviço na Escola Estadual Dom Bosco?

( ) anos ( ) meses

4. Quantas turmas de EM você possui?

( )

5. Quantos estudantes, em média, você têm por sala no EM?

( ) estudantes

6. Trabalha em outras escolas?

( ) $\operatorname{sim}$ ( ) não

7. Número de escolas em que atua.

( )

8. Ministra aulas no ensino fundamental?

( ) $\operatorname{sim}$ ( ) não

9. Qual (is) a disciplina (s) que ministra no ensino fundamental?

10. Quantas turmas você possui no ensino fundamental?

( )

11. Atua somente na rede pública de ensino?

( ) $\operatorname{sim}$ ( ) não

12. Atua em escola da rede privada? 
( ) $\operatorname{sim}($ ) não

13. Exerce outra atividade além da docência?

( ) $\operatorname{sim}$ ( ) não

Qual?

14. Além de biologia, você ministra outra (s) disciplina (s)?

( ) $\operatorname{sim}($ ) não

Qual?

15. Qual a carga horária de biologia? ( )

16. ( ) Qual a carga horária da outra (s) disciplina (s) do EM?

17. Ministra aulas somente da disciplina em que é formado na graduação?

( ) $\operatorname{sim}$ ( ) não

18. Quantos estudantes estão matriculados em média nas turmas no EM? 


\subsection{Apêndice C - Roteiro de entrevista semiestruturada (professoras e estudantes).}

1. Qual o principal recurso didático-pedagógico que você mais utiliza em suas aulas?

2. Você participou do processo de seleção do livro didático?

3. Quais os recursos e/ou atividades você gostaria de poder utilizar em suas aulas?

4. Você está satisfeita com o apoio dado pela coordenação e/ou direção na execução de suas aulas? (em relação à disponibilidade de material didático, uso de novas tecnologias (Projetor, computador), uso dos espaços: como biblioteca, laboratório, salas de aula etc.)

5. Quais outras estratégias você utiliza para motivar os seus estudantes para as suas aulas?

6. Você está satisfeita com a participação dos estudantes nas suas aulas?

7. Descreva brevemente quais são as etapas de uma aula ministrada por você.

8. Ao ensinar um determinado conceito de biologia você costuma considerar os conhecimentos prévios dos estudantes? Com qual frequência?

9. Como você avalia a participação dos estudantes em suas aulas? Você considera satisfatório?

10. Qual (is) a (s) principal forma de avaliação que você utiliza?

11. Você está satisfeita com o desempenho dos estudantes do $1^{\circ}(\mathrm{A}, \mathrm{D}, \mathrm{F})$ nas suas avaliações?

12. Qual é a sua atitude frente aos estudantes que apresentam baixo desempenho nas suas avaliações?

13. Como são preparadas as suas aulas? Explique.

14. Em que medida você avalia o uso dos conceitos de biologia pelo estudante na sua vida cotidiana?

15. Para você, qual principal função do EM na educação básica?

16. Você gostaria de acrescentar algo mais a sua entrevista?

GOSTARIA DE AGRADECER A DISPONIBILIDADE DE TER ABERTO A SUA SALA DE AULA PARA A MINHA PESQUISA 
Roteiro de entrevista semiestruturada (estudantes).

\section{A - Identificação do participante}

1. Nome:

Idade:

Sexo:

2. Quanto tempo frequenta esta escola?

\section{B - Percepção da atividade pedagógica}

1. Em sua opinião o professor solicita e incentiva a participação dos estudantes nas suas aulas? Com qual frequência?

2. Quais os recursos didáticos o professor costuma utilizar em suas aulas? Com qual frequência?

3. Com qual frequência o professor utiliza o livro didático e/ou apostila?

4. O professor leva os estudantes a outros ambientes da escola, como: laboratório, sala de informática ou biblioteca? Com qual frequência?

5. Você compreende facilmente a matéria que o professor quer ensinar?

6. Qual a maneira de ensinar a matéria que você entende que seja a mais eficaz?

7. Ao ensinar a matéria o professor procura considerar os conhecimentos que os estudantes já possuem sobre determinado assunto?

8. Você costuma relacionar a matéria ensinada pelo professor na vida cotidiana? Com qual frequência?

9. O que você acha da avaliação do professor? Esta adequada à sua maneira de ensinar?

10. Como você classificaria o seu desempenho nas avaliações?

11. Explique a maneira que você estuda para a prova? Utiliza somente o livro didático? Utiliza a internet?

12. O que te motiva a estudar biologia?

13. Qual a disciplina de sua preferência?

14. Qual é a disciplina que você tem o melhor desempenho?

15. De uma forma geral como você se sente ao cursar o EM?

16. O que você almeja fazer depois de terminar o EM? 
2.5 Apêndice $D$ - Questionário relativo ao perfil socioeconômico dos estudantes.

1. Sexo:

( ) Masculino ( ) Feminino ( ) outro

2. Faixa de idade:

( ) 11 a 12 ( ) 12 a 13 ( ) 13 a 14 ( ) 14 a 15 ( ) mais de 15 anos

3. Estado civil:

( ) solteira (o) ( ) casada (o) ( ) separada (o)

4. Possui filho/os (a/as)?

( ) $\operatorname{sim}($ ) não

5. Quantas filhas (os):

( ) Não possuo filha/o ( ) 1 ( ) 2( ) mais de 2

6. Em qual cidade você mora?

( ) Corumbá ( ) Ladário

7. Como você se desloca para a escola:

( ) a pé ( ) de bicicleta ( ) de ônibus ( ) de carro ( ) outro meio

8. Você tem computador (desktop ou notebook) em casa?

( ) $\operatorname{sim}($ ) não

9. Você possui acesso à internet em casa?

( ) $\operatorname{sim}($ ) não

10. Possui aparelho celular?

( ) $\operatorname{sim}($ ) não

11. O seu aparelho é um:

( ) smartphone ( ) celular normal

12. $O$ seu celular tem acesso à internet pela rede 3G?

( ) $\operatorname{sim}($ ) não

13. Qual o seu tempo de estudo nessa escola:

( ) é o meu primeiro ano ( ) 1 ano ( ) $2 \operatorname{anos}($ ) $3 \operatorname{anos}($ ) $4 \operatorname{anos}($ ) 5

anos ( ) mais de seis anos

14. Você é estudante repetente do $1^{\circ}$ ano?

( ) $\operatorname{sim}($ ) não

15. Quantas vezes você repetiu o $1^{\circ}$ ano?

( ) 1 vez ( ) 2 vezes ( ) 3 vezes ( ) mais de 3 vezes

16. Você mora com quem? 

(A) com meus pais (pai e mãe)
(B) somente com minha mãe
(C) somente com meu pai
(D) com pai e madrasta
(E) com mãe e padrasto
(F) com minha avó/avô
(G) com outro parente
(H) com esposa/esposo
(I) outro

17. Quantas pessoas moram com você? (incluindo filhos, irmãos, parentes e amigos (Marque apenas uma resposta)

( ) Moro sozinho ( ) Uma a três ( ) Quatro a sete ( ) Oito a dez ( ) Mais de $\operatorname{dez}$

18. A casa onde você mora é? (Marque apenas uma resposta)

( ) Própria ( ) Alugada ( ) Cedida por alguém

19. Sua casa está localizada em? (Marque apenas uma resposta)

( ) Zona urbana ( ) Zona rural ( ) Comunidade indígena. ( ) Comunidade quilombola.

20. Qual é o nível de escolaridade do seu PAI? (Marque apenas uma resposta)

( ) Da $1^{\mathrm{a}}$ à $4^{\mathrm{a}}$ série do Ensino Fundamental (antigo primário)

( ) Da $5^{\mathrm{a}}$ à $8^{\mathrm{a}}$ série do Ensino Fundamental (antigo ginásio)

( ) $\mathrm{EM}$ (antigo $2^{\circ}$ grau)

( ) Ensino Superior

( ) Especialização

( ) Não estudou

( ) Não sei

21. Qual é o nível de escolaridade da sua MÃE? (Marque apenas uma resposta)

( ) Da $1^{\mathrm{a}}$ à $4^{\mathrm{a}}$ série do Ensino Fundamental (antigo primário)

( ) $\mathrm{Da} 5^{\mathrm{a}}$ à $8^{\mathrm{a}}$ série do Ensino Fundamental (antigo ginásio)

( ) EM (antigo $2^{\circ}$ grau)

( ) Ensino Superior 
( ) Especialização

( ) Não estudou

( ) Não sei

22. Quantas pessoas trabalham na sua casa?

( ) 1 ( ) 2 ( ) 3 ( ) mais de 3

23. Faixa de renda da família (somando todos os que têm renda):
(A) De um salário mínimo até dois (de $\mathrm{R} \$ 937,00$ até 1.874,00)
(B) Acima de dois salários mínimos até quatro $(1.874,00$ até $\mathrm{R} \$ 3.741,00)$
(C) Acima de três salários mínimos até dez (R $\$ 3.741,00$ até 9.370,00)
(D) Acima de dez (acima de 9.370,00)
(E) Não sei

24. Você trabalha ou já trabalhou?

（） $\operatorname{sim}(\quad$ ) não (SE VOCÊ OPTOU PELO “NÃO”, NÃO SERÁ PRECISO RESPONDER AS OUTRAS QUESTÕES)

25. Em que você trabalha atualmente? (Marque apenas uma resposta)

(A) Na agricultura, no campo, na fazenda ou na pesca.

(B) Na indústria.

(C) Na construção civil.

(D) No comércio, banco, transporte, hotelaria ou outros serviços.

(E) Como funcionário (a) do governo federal, estadual ou municipal.

(F) Como profissional liberal, professora ou técnica de nível superior.

(G) Trabalho fora de casa em atividades informais (pintor, eletricista, encanador, feirante, ambulante, guardador/a de carros, catador/a de lixo).

(H) Trabalho em minha casa informalmente (costurar, aulas particulares, cozinha, artesanato, carpintaria etc.).

(I) Faço trabalho doméstico em casa de outras pessoas (cozinheiro/a, mordomo/governanta, jardineiro, babá, lavadeira, faxineiro/a, acompanhante de idosos/as etc.).

(J) No lar (sem remuneração)

(K) Outro.

(L) Não trabalho.

26. Indique o grau de importância de cada um dos motivos abaixo na sua decisão de trabalhar: (Atenção: 0 indica nenhuma importância e 5 maior importância. MARQUE COM UM X SOBRE O NÚMERO) 
Ajudar nas despesas com a casa

$(0-1-2-3-4-5)$

Sustentar minha família (esposo/a, filhos/as etc.) $\quad(0-1-2-3-4-5)$

Ser independente (ganhar meu próprio dinheiro) $\quad(0-1-2-3-4-5)$

Adquirir experiência

$(0-1-2-3-4-5)$

Custear/ pagar meus estudos

$(0-1-2-3-4-5)$

27. Quantas horas semanais você trabalha? (Marque apenas uma resposta)
(A) Sem jornada fixa, até 10 horas semanais.
(B) De 11 a 20 horas semanais.
(C) De 21 a 30 horas semanais.
(D) De 31 a 40 horas semanais.
(E) Mais de 40 horas semanais 